\title{
Feeding as a Force of Production and Advancement in the Peruvian Andes
}

\author{
Marieka Sax \\ (BA Great Distinction, University of Regina, 2005)
}

\author{
A thesis Submitted to the \\ Faculty of Graduate Studies and Research \\ in partial fulfilment of the requirements \\ for the degree of Master of Arts \\ Department of Sociology and Anthropology \\ Carleton University \\ Ottawa, Ontario, Canada \\ December 2008
}

(C) 2009, Marieka Sax 


$\begin{array}{ll}\begin{array}{l}\text { Library and } \\ \text { Archives Canada }\end{array} & \begin{array}{l}\text { Bibliothèque et } \\ \text { Archives Canada }\end{array} \\ \begin{array}{l}\text { Published Heritage } \\ \text { Branch }\end{array} & \begin{array}{l}\text { Direction du } \\ \text { Patrimoine de l'édition }\end{array} \\ \begin{array}{l}\text { 395 Wellington Street } \\ \text { Ottawa ON K1A 0N4 } \\ \text { Canada }\end{array} & \begin{array}{l}\text { O95, rue Wellington } \\ \text { Ottawa ON K1A 0N4 } \\ \text { Canada }\end{array}\end{array}$

Your file Votre référence ISBN: 978-0-494-47503-4

Our file Notre référence

ISBN: 978-0-494-47503-4

NOTICE:

The author has granted a nonexclusive license allowing Library and Archives Canada to reproduce, publish, archive, preserve, conserve, communicate to the public by telecommunication or on the Internet, loan, distribute and sell theses worldwide, for commercial or noncommercial purposes, in microform, paper, electronic and/or any other formats.

The author retains copyright ownership and moral rights in this thesis. Neither the thesis nor substantial extracts from it may be printed or otherwise reproduced without the author's permission.
AVIS:

L'auteur a accordé une licence non exclusive permettant à la Bibliothèque et Archives Canada de reproduire, publier, archiver, sauvegarder, conserver, transmettre au public par télécommunication ou par l'Internet, prêter, distribuer et vendre des thèses partout dans le monde, à des fins commerciales ou autres, sur support microforme, papier, électronique et/ou autres formats.

L'auteur conserve la propriété du droit d'auteur et des droits moraux qui protège cette thèse. $\mathrm{Ni}$ la thèse ni des extraits substantiels de celle-ci ne doivent être imprimés ou autrement reproduits sans son autorisation.
In compliance with the Canadian

Privacy Act some supporting forms may have been removed from this thesis.

While these forms may be included in the document page count, their removal does not represent any loss of content from the thesis.
Conformément à la loi canadienne sur la protection de la vie privée, quelques formulaires secondaires ont été enlevés de cette thèse.

Bien que ces formulaires aient inclus dans la pagination, il n'y aura aucun contenu manquant.

\section{Canada}




\section{$\underline{\text { Abstract }}$}

Food and other consumables are a medium for the life-giving energy or sami inherent in all matter, as well as for social relationships that connect Andeans to both autochthonous powers embodied in the landscape and to each other. Through the feeding of others in contexts both formal and informal, ties of affinity are acknowledged and maintained, business relationships are forged, and social identities are created. At the same time, through the idiom of feeding, these consumables are a vehicle for the circulation of sami, the fertilizing and animating essence that derives from divine powers who are the ultimate source of abundance, prosperity, health, and well-being. Within the logic of this circulatory system, the feeding of others is necessary for Andeans to "progress" and "advance" both in the countryside and the city. (Andes, ritual, food, migration, informal economy, place, practice, embodiment) 


\section{Acknowledgements}

Fieldwork was carried out from July 2007 - March 2008 with funding provided from the Social Sciences and Humanities Research Council of Canada (SSHRC). Thanks to the support of my parents David and Karen Sax, my thesis supervisor Peter Gose, and the "Bautista" family. 


\section{Table of Contents}

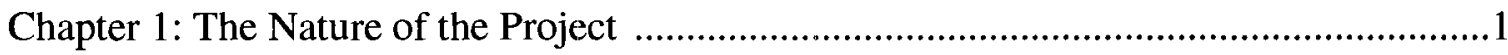

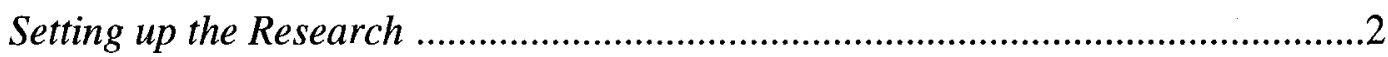

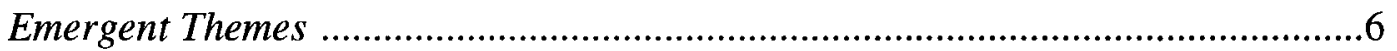

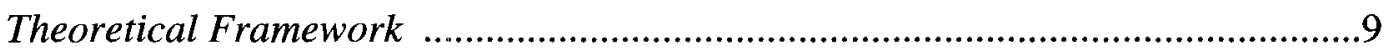

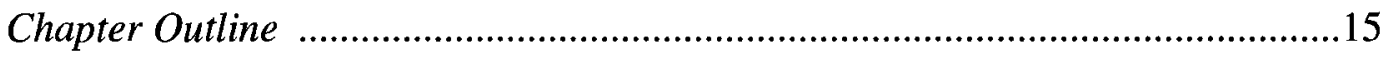

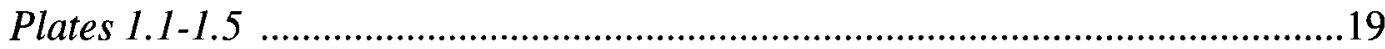

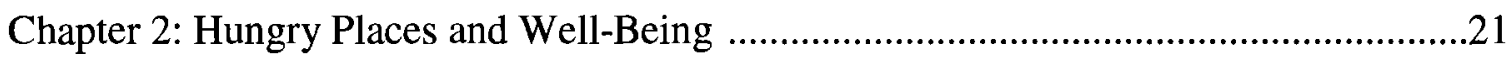

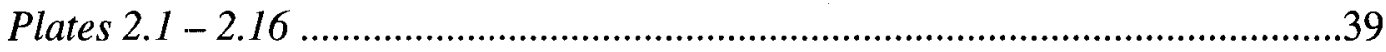

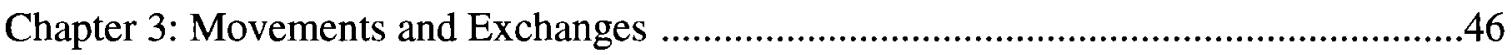

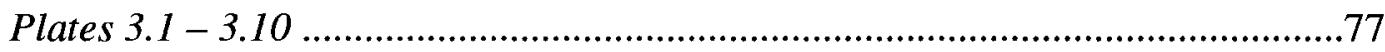

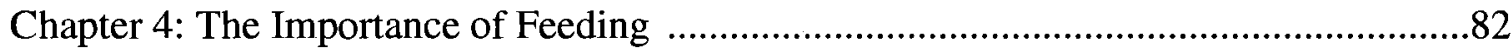

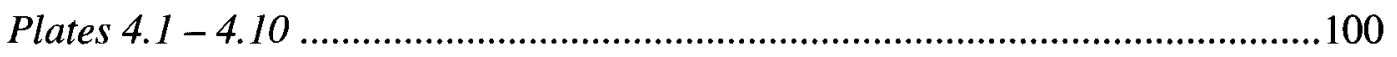

Chapter 5: Feeding as a Force of Production and Advancement .................................105

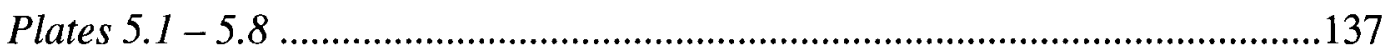

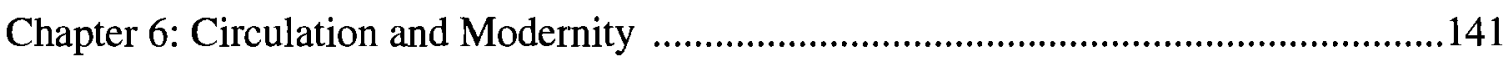

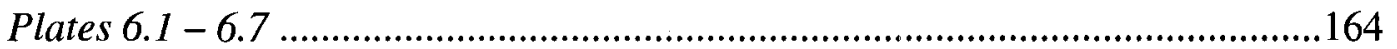

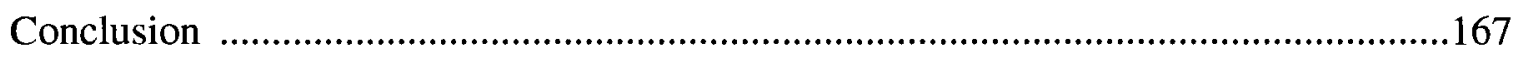

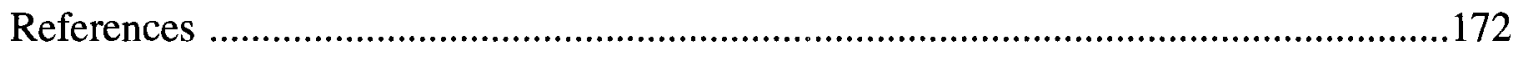




\section{List of Plates}

Plate 1.1: The Bautista family .................................................................................19

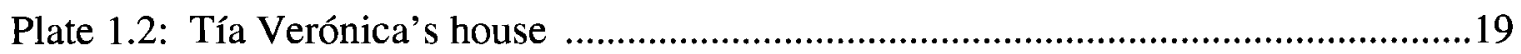

Plate 1.3: Pedro's eldest sister, Verónica ..........................................................................20

Plate 1.4: Pedro and Verónica's mother, "Mamaku” ..........................................................20

Plate 1.5: Rosa helps her mother prepare sopa in her kitchen ..........................................20

Plate 2.1: A view of Bautista family lands ………........................................................39

Plate 2.2: The family prepares for the herranza .............................................................39

Plate 2.3: Men use ropes to catch the cattle ...................................................................

Plate 2.4: Maurelio chews coca, with wife and grandson to the left ................................40

Plate 2.5: The family drinks and dances ....................................................................

Plate 2.6: Maurelio and his wife catch the sheep in their corral .......................................41

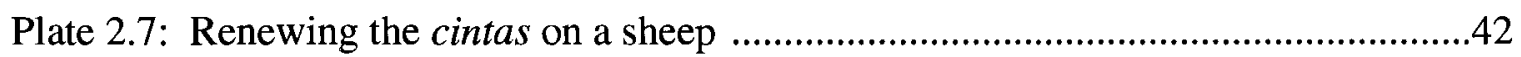

Plate 2.8: Children catch the sheep as well ..............................................................42

Plate 2.9: A young boy earns his trago …………………............................................42

Plate 2.10: Maurelio and his wife are adorned with necklaces of bread and fruit ...........43

Plate 2.11: Everyone got down on all fours and baa-ed like sheep ..................................43

Plate 2.12: Chewing coca and singing songs of Santiago..................................................44

Plate 2.13: Ritual mesa for the Fiesta de Santiago ...........................................................44

Plate 2.14: Preparing to wash clothes in the Río Wichjana ...............................................45

Plate 2.15: Don Pedro in costume as a Danzante de los Tijeras ........................................45

Plate 2.16: Cerro Huallanca with the Río Wichjana at its base ..........................................45 
Plate 3.1: A view of Paucará from atop Calvario

Plate 3.2: Taking a break to eat lunch while planting potatoes .......................................77

Plate 3.3: Verónica butchers a sheep that has fallen ill and died .......................................78

Plate 3.4: Deposits that Verónica found in the sheep's chest .........................................78

Plate 3.5: An Evangelical "culto" in the hills of Cerro Calvario ........................................79

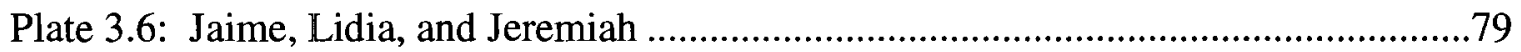

Plate 3.7: The fresh fruit and vegetable sections in the market .......................................80

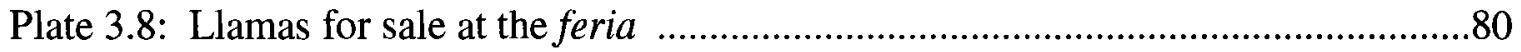

Plate 3.9: Susana and Teofilia at her food stall in the marketplace .................................81

Plate 3.10: Teofilia exchanges habas for chirimoya at the trueque .................................81

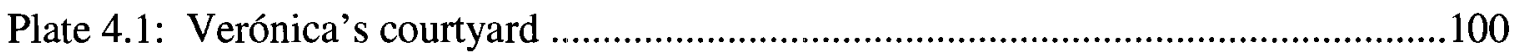

Plate 4.2: Verónica serving the daily sopa …………….............................................100

Plate 4.3: Lidia's kitchen, with gate facing Verónica's house …….................................101

Plate 4.4: Washing dishes in Mamaku's kitchen ........................................................101

Plate 4.5: Pedro's distant cousin Frederico, with wife and youngest son ......................102

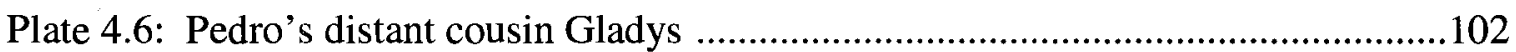

Plate 4.7: Relaxing in the courtyard with treats brought from town ...............................103

Plate 4.8: Food is used to seal ties of compadrazgo .....................................................103

Plate 4.9: Mourners washing clothes of the deceased at a pichja ..................................104

Plate 4.10: "People will think we fed you only because you worked" ............................104

Plate 5.1: Jeremiah uses a foot plow to turn over soil .....................................................137

Plate 5.2: Manuel makes rows using a hand pick ......................................................137

Plate 5.3: Rosa plants seed potatoes …………………….............................................138 
Plate 5.4: Mamaku brings her sheep back from the pasture

Plate 5.5: El Mercado de la Brujería

Plate 5.6: Pre-Incan burial cavities

Plate 5.7: Susana at her cevichería

Plate 5.8: Pedro's brother at his abarrotes store

Plate 6.1: The abandoned Bautista homestead

Plate 6.2: Close-up of Pedro and Susana's old house

Plate 6.3: Pedro and Susana's cement and brick house in Bayovar 164

Plate 6.4: Yhosef invites a tourist to have a meal in his family's home 165

Plate 6.5: Frederico's second son is a policeman 165

Plate 6.6: Re-enactment of the Fiesta de Santiago 166

Plate 6.7: Three generations .166 


\section{Chapter 1: The Nature of the Project}

In July 2007 I landed in Lima with the intention of carrying out participantobservation fieldwork on the relationships between food systems, markets, and concepts of landscape and belonging in the southern Peruvian highlands. Armed with an ambitious research proposal, questionably useful field equipment, and a dubious sense of geographical orientation, I planned to leave Lima within two weeks to travel down the coast and into the mountains to reach the provincial and district capital of Chuquibambilla in the department of Apurímac, situated between Cuzco and Arequipa.

From the outset, I was concerned with the connections between agro-pastoral rituals in the countryside (and the feeding of autochthonous powers and workers that play a central role in agriculture and ritual in the Andes) and the feeding of patron saints in the marketplace in cities. I was also interested in an Andean sense of "place" as well as the food and cuisine of the highlands, although it was not clear to me how or if they were connected to ritual feeding in the region. Intuitively, I sought to investigate practices surrounding food in the household to ultimately link social, political-economic, cosmological, and ontological themes. The lived world is ever so much more muddled and messy, however, and while I was in the field I wondered if my line of questioning was going anywhere at all. It was only after months of fieldwork, reflection, and writing that I realized that it is through the myriad practices surrounding food, particularly feeding in various contexts, that threads emerge connecting agricultural production in the city to the market-based activities of urban migrants, and that the lives of Andean people 
in the country and the city can be seen as interwoven in a sense that is at once symbolic and practical.

\section{Setting up the Research}

July 16, 2007. First morning in Lima. I walk from my hostel to the Parque Kennedy in the tourist centre of Miraflores to have a look around my new surroundings. I really have no idea where I am going or how I will reach Apurimac, although I hope my contact at the Universidad Pontificía Católica del Perú will be able to point me in the right direction. After a couple of hours, I decide to head back to the hostel. Although I know where I am, I cannot figure out how to find the right streets that will lead me back. I resort to doing what I vowed never to do and pull out my guidebook on the street. While squinting at the tiny map, a clandestine ambulant necklace seller spots me and walks up to me, asking if I want to buy something. No, I reply, inwardly kicking myself for setting myself up. The vendor is persistent, determined to strike up a friendly conversation: Where am I from? What am I doing here? Would I like to sit down and have supper at a nearby tourist restaurant? And then something unexpected happens. I find this young man sincere, and I begin to trust him. He invites me to his family's home for a "real Peruvian dish" of ceviche prepared by his mother. I accept, and although I do not plan on actually going, he finds me two days later and insists on taking me to his house. Against my own caution but determined to fully "submit myself to the process" (a thought my thesis supervisor had planted in my mind years previously), I agree to visit his family's home in the outlying municipality of San Juan de Lurigancho. 
So begins my introduction to the Bautista family and my fieldwork based in their neighourhood of Bayovar (San Juan de Lurigancho, Lima) and their natal community of Paucará (capital of the district of Paucará, province of Acobamba) in the department of Huancavelica. Through synchronistic good fortune, I was taken in by a family that had moved to Lima from their home in the highlands south-east of the capital some ten years previously. The young man I met on the street in an elite heart of Lima was Yhosef, the eldest son of don Pedro Bautista and doña Susana Ortega Bautista.' They have three boys and three girls. The eldest daughter has her own home in the same neighbourhood of Bayovar, where she lives with her husband and two-year-old daughter. Pedro and Susana's remaining children all live at home; their three youngest are still in elementary and secondary school. As so many urban migrants in Peru, they make their living as ambulantes (street vendors) by performing a service or selling something on the street. The Bautistas are remarkably good-natured and kind-hearted people, and came to treat me like their own daughter. They offered me free room and board in their house in Bayovar, assisted me in all my errands in Lima, and invited me to stay with their extended family in Paucará so that I could carry out my fieldwork.

Although I did travel to Chuquibambilla (Apurímac) to see what sort of field site it would be, in the end it made much more sense to take advantage of the opportunity that had been granted me and change my research site to Huancavelica. The district of Paucará presented some problems for my research expectations, but turned out to be an ideal location for investigating connections between the countryside and the city. ${ }^{2}$ For

\footnotetext{
${ }^{1}$ All informant names are pseudonyms.

${ }^{2}$ Moreover, much more ethnographic work has already been carried out further south where I originally had planned to go, including the departments of Ayacucho, Apurímac, Arequipa, Cuzco, and Puno (see for example Collins 1988; Gelles 2000; Gose 1994; Isbell 1978; Mitchell 1991; Paerregaard 1997; Sallnow
} 
example, in contrast to Chuquibambilla, people do not grow corn in Paucará; at the highest district in the province of Acobamba, it sits at 3806 meters above sea level (masl), which is too high for corn cultivation. Therefore, although I had purposefully chosen my arrival date to correspond to the time of year for yarqa aspiy (canal cleaning), my informants repeatedly told me that no such agricultural activity occurs in July or August. Since maize is the principle crop that is irrigated in the highlands, and people do not generally irrigate in Huancavelica, no such canal cleaning is necessary. However, my informants insisted that I witness the Fiesta de Santiago (July 25), in which herd animals are blessed for an upcoming agro-pastoral year. This ritual event was unanticipated ${ }^{3}$ yet turned out to lay the groundwork for my research. Thanks to the Bautistas, I was able to observe and participate in the most important event in the annual agro-pastoral calendar in Huancavelica ten days after arriving in the country.

I first arrived in Paucará several weeks later, when I traveled to the district with Susana and Yhosef at the beginning of September. Our arrival coincided with the Fiesta de Mama Cocharcas (September 8), the town's patron saint, and the first week was occupied by festival activities. Paucará was bustling with the many people who were also visiting from cities or other towns for the fiesta; although outsiders and gringos are by no means common in the district, people were more surprised when they saw that I intended to stay on past the festival week. I arrived in Paucará on the invitation of the Bautistas, and all my interactions with people occurred in the context of my connection to this family. During the week of Mama Cocharcas, Susana introduced me to various friends

1987; Seligmann 2004; Skar 1994; Trawick 2003). Conversely, Huancavelica remains a less well-studied area and thus offers the possibility of additional perspectives.

${ }^{3}$ Andean communities carry out such herranzas at different times of the year that vary from one place to another; I was unaware at the time that in Huancavelica the herranza is specifically associated with the Fiesta de Santiago (see Fuenzalida 1980). 
and relatives, who further invited me to visit or stay with them. As a family guest then, I did not seek formal permission of town authorities to carry out my research. Since my activities and inquiries were basically limited to members of the Bautista family, it did not seem necessary.

Most of my time was spent in the homes and in the company of Pedro's siblings. I ultimately settled in the home of Verónica, Pedro's eldest sister. In fact, from the beginning Pedro suggested that I live with his sister, who was sure to take good care of me, and who would greatly appreciate the company. Verónica is widowed and lives alone about a half an hour's walk out of town. For the most part, I slept in her home, ate in her kitchen, and accompanied her to her fields while tending her sheep, or to town for occasional errands. I also spent considerable time with Verónica's grown daughter Rosa and her husband and children, with Verónica and Pedro's elderly mother ("Mamaku"), and with the families of their other sisters Lidia and Teofilia, who also live on nearby farms. In town, I had contact with Pedro's two distant cousins, Gladys and Frederico. I initially spent a week living with Gladys and her family in town. Frederico also invited me to stay with his sons in the city of Huancavelica, where I traveled every couple of weeks to write up my field notes.

In fact, although my main field site was Paucará, I actually was in constant movement between the town, households in the countryside, and the cities of Huancavelica and Lima. This is not so unlike the rhythms of the lives of many of my informants, who often travel between the countryside and the city for work, education, and family needs. The time I spent in Huancavelica and Lima at first established valuable 
reference points to contrast with Paucará; now I see them as fundamental to gaining some idea of the movements and contrasts that characterize the lives of many Andeans.

\section{Emergent Themes}

I arrived in the field with the expectation and intention of focusing on place, and I soon found the place of Paucará to be problematic. It was not simply problematic for me, as it did not adhere to my expectations of a typically "Andean" ${ }^{4}$ community; it also seemed to be problematic for Paucareños. It appears that those with the means choose to leave Paucará for cities such as Huancavelica and Lima; except for the very poor, children old enough to attend secondary school or work move to the city, and many men spend much of the year working in Lima, returning mainly for agricultural and festival activities. The town of Paucará is sizable and has a lively Sunday market, but hamlets and homesteads surrounding the town seem to hold an air of absence or decline. These places did not seem to be as "alive" as they should be, with multi-generational household members carrying out various productive and household activities together and alongside one another. Rather, women are left tending sheep, along with the very old and the very young, while men seek wage labour in cities such as Huancavelica and Lima for much of the year, and many houses have fallen into disrepair or been abandoned altogether. Instead of pooling labour resources, people plant their fields and tend their households without reciprocal exchanges which, if they do not increase the actual labour available, ${ }^{5}$ at least contribute to the strengthening of social bonds and social solidarity. Indeed, I

\footnotetext{
${ }^{4}$ From time to time I will place "Andean" in quotation marks to draw attention to its use as an analytical category. Its wide use in the ethnographic and social science literature has merit, but is also being continuously renegotiated and redefined.

${ }^{5}$ I am indebted to Peter Gose for this observation.
} 
observed some family members seemingly going out of their way not to help one another, and others having very little practical affinity with each other.

There are three identifiable processes that I found surprising in Paucará. Firstly, while Paucareños evidently value reciprocal exchanges, I did not observe the sorts of reciprocal work exchanges that are, according to the ethnographic literature, supposed to be characteristic of the Andes. While people told me they practiced ayni (work in exchange for like work), what I actually observed was that the reciprocation of work accompanied by the all-important provision of food and alcohol - was not sufficient for Paucareños to access the labour of others. Instead, people worked their fields with only the aid of immediate family members; communal tasks that are carried out in other areas of the Andes such as house rethatching (see Gose 1991, 1994) do not seem to be considered feasible in Paucará. For example, the homes of both Verónica and Mamaku were in demonstrable need of repairs, but when I asked family members about what was to be done, they indicated that there was no money to hire workers. Admittedly, the general sentiment was that they would not need their homes for very many more years, either by moving to the city or the extinguishment of their lives. Yet it is striking that family members (and here I am thinking specifically of the sibling set to which Verónica belongs) did not seem to consider it important to invest in the maintenance of existing infrastructure. Such disregard is indicative of a wider process of disinvestment in communal structures and relationships based in the countryside.

This is in some way contiguous with the ways that Paucará as a Place ${ }^{6}$ is problematic. For a myriad of reasons, people (especially youth) are electing to not just

\footnotetext{
${ }^{6}$ I will from time to time refer to "Place" as an analytical category that encompasses spatial, temporal, and symbolic dimensions (see Casey 1996) and to special individualized "Places" (see Allen 2002[1988]), as
} 
engage in urban wage employment as part of a wider livelihood strategy (as indeed many Andeans have done for generations), but to abandon Paucará altogether as a viable place for establishing a household. At the same time that Paucareños are neglecting and deinvesting in their places of origin, ${ }^{7}$ it appears that these very Places are abandoning them. Instead of endowing health, fertility, and prosperity as the tutelary mountain spirits should do, their Places bring them sickness and misfortune, as evidenced by the hunger of malevolent diablos (devils) that are similarly emplaced, associated with particular hollows or pools of water, or the local climate. Thus at a certain point, notions of sickness and curing emerged as prominent themes in my fieldwork.

To attend to Andean ideas of sickness and curing in a satisfactory way would require an ethnographic study itself (see for example Crandon-Malamud 1991). What soon came to eclipse these cosmological/medical/corporal issues in prominence for my present research was the "hunger" of the emplaced powers and the "feeding" that is necessary to assuage them. The idiom of feeding is so important in so many different contexts in Andean society, and indeed in gaining some insight into what may be thought of as an "Andean" orientation to the world, that it sits at the heart of this thesis. As we shall see, the idiom of feeding continues to be important for Paucareños who elect to establish themselves in the city, where they pursue productive and advancing activities that the countryside does not offer.

indicated by capitalization. At other times, "place" remains uncapitalized when evoking the more general use of the concept as a geographical location.

${ }^{7}$ I must caution that this is based on general observations of the families I knew and not more extensive survey or statistical analysis, for example of remittances sent from Lima to Paucará. However, the palpable air of decline and disinvestment is in contrast to other Andean communities, in which urban migrants consistently send money and resources back to their natal communities to support family members, build houses, host fiestas, and generally invest in the infrastructure and society of their rural towns (see for example Paerregaard 1997; Skar 1994). 


\section{Theoretical Framework}

From a theoretical perspective then, this thesis is very much concerned with practice, symbol, and experience. More specifically, I am interested in the "practical logical consequences" (Alston 1956: 82) of an Andean orientation to, engagement in, and experience of the world. What emerges from a consideration of the coherent totality of the driving logic of feeding in its various contexts, in an ongoing process of unfolding and "revision of the anticipations of understanding" (Grondin 2002: 47), is a view of how Paucareños, as actors in a "modernizing" world engaged in certain practices, are able to open up new fields of experience and new possibilities for their lives without becoming totally "unhinged" from past horizons. From this perspective, I intend to use a Gadamerian hermeneutics to bridge a phenomenological understanding of being-in-theworld with a Peircian notion of practice that in some way accounts for how Paucareños can be seen as pursuing apparently "modern" goals (education, monetary employment, consumer goods, a certain standard of living) without becoming "homogeneously modern" and subsumable under a meta-narrative of modernity.

My observations and comments on the practical outcomes of the symbolic logic that underlines habitual and reiterative practices and emplaced tasks are informed by Charles Sanders Peirce's semiotic triad of object, sign, and interpretant: a sign points to an object, which "sparks a subsequent sign (an interpretant) in the mind of the interpreter" (Misak 2004: 10, also 8-9). The relevant thing about the interpretant here is that it results in "pragmatic meaning" and in "consequences for action and thought" (Misak 2004: 9). Thus Peirce characterizes practice as the "final logical interpretant" (Alston 1956: 83; Misak 2004: 10). 
Although I am interested in practice as the outcome of a systematic logic, I am hesitant to agree with Peirce's characterization of this pragmatic meaning as "rational conduct" (Misak 2004: 9). Besides a general objection to the characterization of humans as fundamentally rational beings, I am not convinced by the proposition that behaviors and meanings are evaluated and employed rationally, even if that rationality may be guided by an internal logic (cf. Bourdieu 1990[1980]: 50). As Peirce himself asserts, these very practical logical consequences have an effect on thought and action and can themselves be thought of as the outcome of a "belief-habit" (Misak 2004: 11).

It is here that I would like to insert Pierre Bourdieu's idea of the "habitus" as a way to think about how habit-belief can appear to adhere to an internal rationality (and that structures that very habit-belief) without the individual actually needing to employ rationality per se (see Bourdieu 1990[1980]: Chapter 3). Thus practice and practical meaning can be guided by a habit-belief that is at times merely a conventional disposition, a "structuring structure" that systematically frames and shapes practice (Bourdieu 1990[1980]: 53). While a defining characteristic of the habitus is that one does not actually have to think about it in order for it to structure practice (see Bourdieu 1990[1980]: 53), in my reading of Bourdieu individuals also have the capacity (within the parameters of the habitus) to innovatively and creatively respond to new contexts by nondiscursively making use of their habitus in improvised ways (see Bourdieu 1990[1980]: 53, 55-56). Bourdieu attributes this improvisational possibility to the "infinite yet strictly limited generative capacity" of the habitus: "the habitus, like every 'art of inventing', is what makes it possible to produce an infinite number of practices 
that are relatively unpredictable (like the corresponding situations) but also limited in their diversity" (Bourdieu 1990[1980]: 55).

The very nondiscursiveness of the habitus means that one does not actually have to articulate or rationalize why one would, for example, feed divine powers in the urban marketplace to push them towards prosperous and fertile outcomes just as one does in the countryside. This creative possibility in the insertion of new experience (see Bontekoe 1996) lends further insight and understanding to Peirce's characterization of practice as the "final logical interpretant," thereby pointing to a way out of the "vicious" hermeneutical circle (Grondin 2002: 46; Bontekoe 1996) of interpretants (signs) only being defined by ever more interpretants (see Misak 2004: 10).

If a sign is meaningful insofar as it "addresses somebody" (Daniel 1984: 21) by whom it is interpreted specifically in relation to "habits of action" (Alston 1956: 86), then it is these very practices that must be attended to if we are to gain some insight or understanding in the Gadamerian sense. In this evocation of hermeneutical understanding, I am referring specifically to the interpretive process represented by this thesis and generally not the understanding that Paucareños have of their own practices. (Although, as we shall see, this Gadamerian sense of understanding is also applicable to the practices of informants themselves to some degree).

Here I refer to Hans-Georg Gadamer's elucidation of hermeneutical "understanding" as at once intellectual grasp, practical know-how, and agreement (Grondin 2002; see Gadamer 2004[1975]: 294-321). In some sense the threefold "understanding of understanding" (Grondin 2002) can be seen as referring to these dialogical and mutually intelligible domains. Understanding can at first be seen as "an 
epistemological or cognitive process" in which meaning is grasped and seen clearly in relation to a larger frame of reference (Grondin 2002: 36). Secondly, understanding can be seen as the ability or capacity to do something - in Heideggeran terms, as a "possibility for our existence" (Grondin 2002: 37). Thus understanding always involves a practical application (Grondin 2002: 37-39). Following Aristotle, understanding is meaningful precisely in its application: "Because practice is all about action, it is of no use to have an abstract notion of the good... What counts is to be able to do the good in human affairs" (Grondin 2002: 39; see Gadamer 2004[1975]: 310-311).

Finally, understanding in Gadamerian terms can also be seen as agreement or accordance, a mutual agreement or understanding of the matter at hand (Grondin 2002: 39-41). This aspect of understanding can most obviously be seen in a linguistic sense, for example of a reader or interpreter of a text who has a basic agreement "about what the text is about" (Grondin 2002: 40). But to take a very everyday example, many dishes with different preparation techniques and ingredients can be thought of as "soup" based on the agreement or mutual understanding of soup as a more or less savory, water-based dish usually served hot and made with an accepted range of starches, vegetables, and meat (see Weismantel [1988] for a more in-depth semiotic analysis). While Gadamer indeed does see language as the ground for "every understanding process" (Grondin 2002: 41; Gadamer 2004[1975]: 385-397), the relevant thing here is the very agreement, accordance, or mutual understanding of the matter at hand and the application of that agreement. 
This Gadamer condenses in his ultimate notion of understanding as "application" or "translation," as an attempt to understand something in one's own words or in one's own terms (Grondin 2002: 42-43; Gadamer 2004[1975]: 306-308, 318-321):

The meaning (event, person, monument) that is to be understood is always one that needs to be translated, so that understanding, application, and translation become almost equivalent terms for Gadamer. What I seek to translate (understand, apply) is always something that is at first foreign to me, but that is in some way binding for my interpretation.... Understanding, as an application, is thus always a challenge, but I can only raise up to it if I succeed in finding words for what needs and cries to be understood. (Grondin 2002: 43)

Importantly, this understanding is "tentative" and open to revisions and reevaluations: "our understanding is always subject to revision when confronted with more convincing evidence and interpretations (which can only be articulated in words we can understand and follow)" (Grondin 2002: 44). Here the affinity of a Peircian semiotic pragmatism with a Gadamerian hermeneutics and their role in an interpretive analysis comes to the forefront. Understanding starts off "with vague anticipations of the whole" which are revised and re-evaluated the more we engage with the matter at hand (Grondin 2002: 44; see Gadamer 2004[1975]: 294). In seeking to understand, we start off from the perspective of our own "fore-meanings and prejudices" or "anticipations" (see Gadamer 2004[1975]: 271) that are revised as they encounter and potentially merge with other "horizons" (see Gadamer 2004[1975]: 271-278, 300-306). A horizon is the field of perception and experience that follows from a particular vantage point or perspective, which itself arises out of a historical experience (see Gadamer 2004[1975]: 300-302). A horizon is "something into which we move and that moves with us" (Gadamer 2004[1975]: 303), and therefore as we come to understand, a "real fusing of horizons 
occurs" (Gadamer 2004[1975]: 306): "Thus the horizon of the past, out of which all human life lies and which exists in the form of tradition, is always in motion" (Gadamer 2004[1975]: 303). These prejudices are "conditions of understanding" (Grondin 2002: 44) that can never be totally transcended, but which can be revised or partially abandoned if found to be "inept or fruitless" by our experiences that call such anticipations into question (Grondin 2002: 45).

Gadamer follows Heidegger in "the phenomenological insight that every interpretation draws on anticipations of understanding" (Grondin 2002: 47; see Gadamer 2004[1975]: 268-273). For Gadamer and Gadamerians, it is emphatically not the case that interpretation is "nothing but the confirmation of a preestablished understanding" (Grondin 2002: 47), thus relegating meaning to the "vicious" hermeneutical circle outlined above. Rather, the hermeneutical circle can be seen as an heuristic device to describe "the constant process that consists of the revision of the anticipations of understanding in light of a better and more cogent understanding of the whole" (Grondin 2002: 47; see also Bontekoe 1996; Gadamer 2004[1975]: 268-273). A coherent whole of meaning is presupposed; if this agreement concerning the issue at hand fails (as indeed it can and periodically should), that is if we experience the shattering of our "anticipations of understanding" (Grondin 2002: 40,44), then our understanding is revised to reintegrate our new experience back into a coherent whole (see Grondin 2002: 47-48). Thus, in response to the ways in which my anticipations were "shattered" by the experience of fieldwork, in the forthcoming chapters I will seek to integrate observations from seemingly disparate fields of experience into a greater whole, including agro- 
pastoral production, ritual curing, market activities, culinary practices, and the performance of sociality.

In another sense, however, a hermeneutical orientation is an important point of contrast that lends insight into the pre-interpretive, practical understandings of Paucareños themselves (see Shusterman 1991). Even if people are coming to apparently desire and pursue similar things, it does not follow that they are becoming "more the same" or "more homogeneously modern." As my fieldwork demonstrates, Paucareños pursue these goals if not entirely on their own terms, then at least starting from their own preconceived understandings (prejudices, anticipations). This is something that a hermeneutical approach highlights: that people perceive the world from a certain perspective, but that said perspective can also (and should) be questioned and reevaluated in light of emergent experiences. To put it crudely, people can thus incorporate the "new" without wholeheartedly abandoning the "old," and in Gadamerian terms, emergent horizons can open up as one horizon meets another. Because of the constant process of reevaluation and reintegration, the "to-and-fro motion of any attempt at understanding, from the parts to the whole and from the whole back to the parts" (Grondin 2002: 47; see also Gadamer 2004[1975]: 291), new fields of experience and life possibilities do not (cannot) become totally "ungrounded" from past horizons.

\section{Chapter Outline}

The first main chapter, "Hungry Places and Well-Being" describes the animated Andean landscape and the embodied powers that are integral to the experience of place in the highlands. These embodied powers are principally the mountain spirits or lords 
(called cerros in Paucará) and the earth or pachamama, who are the ultimate sources of life, fertility, prosperity, and well-being. When propitiated through proper ritual offerings (made through an idiom of feeding), these divine powers are generally benevolent and care for the people, herds, and crops under their tutelage. However, Andean places are also animated by more ambiguous figures and malevolent, disembodied forces, such as gentiles and tios who inhabit mountains and mines, fat-extracting pishtakus, and diablos and sirenas who exist on the air or in pools of water. Therefore, this chapter looks at the agro-pastoral and health-concerned rituals that are so important to production, community, and life in the highlands, at the same time that it introduces some problems of Place that emerged through field work in relation to animating powers, such as sickness caused by hungry diablos.

Chapter 3, "Movements and Exchanges" describes Paucará and the lives of my informants in terms of the various movements (relating to work, education, and desire) and exchanges (ritual, social, and market-based) that are significant aspects of their lives and experiences. The lives of Andeans confound implicit dichotomies of modern/urban and traditional/rural. For example, Paucareños increasingly desire and pursue strategies of livelihood and personal "advancement" in the city, yet they also continue to be interpolated by and corporally connected to animating forces in the countryside and find it necessary to address these and other divine powers. In this discussion, the notion of "feeding" (and the reciprocal exchanges thus entailed) is foreshadowed as a force of health, well-being, progress, advancement, and sociality in the Andes.

The following chapter, “The Importance of Feeding" further describes and explains the importance of feeding in Andean society. In formal and informal contexts, 
with greater or lesser degrees of an expected outcome, the feeding of others is highly significant for the forming and strengthening of social bonds, a notion of affiliation, and an articulation and demonstration of a performative social identity. In its most general sense, feeding creates a social context in which the other is obligated to reciprocate in some manner. Feeding has a force and efficacy that is at once social and ritual, and thus the feeding of divine figures is hermeneutically connected to the feeding of social actors.

This sets the stage for Chapter 5, "Feeding as a Force of Production and Advancement." This chapter more explicitly outlines and links the role of feeding in agro-pastoral production, mining, market activities, well-being, and Andean sociality in general. Feeding thus is revealed as something that animates and drives productive activities and subsistence strategies, as well as uniquely Andean ideas of "progress" and "advancement" in both the countryside and the city. As a practically and symbolically rich type of exchange, feeding not only permeates various aspects of Andean life, but also keeps things in movement, pointing to the circulation of life-energy that is implicit in these various movements and exchanges.

In Chapter 6, "Circulation and 'Modernity,"” the logic of this circulatory system that informs feeding in its various contexts is outlined and connected to Andean desires and goals that may be seen as "modernizing" without fully adhering to the meta-narrative of "modernity." In a cosmological sense, this circulatory system directs the flow of lifegiving energies; at the same time, productive and progressing outcomes are the expected practical consequences of feeding. Urban movement and migration can be seen as a logical extension of Andean strategies of progress and advancement, rather than merely the result of political-economic contingencies. 
Indeed, as outlined in the conclusion, my fieldwork suggests that urban migration for Paucareños may be in part driven by a threshold of perception of declining efficacy of the reciprocal relationships that people have to their Places and to each other. The comments and actions of informants suggest that these relationships (often articulated through feeding) have come to be seen as no longer productive and advancing to the expected extent or in desired ways in the countryside. In contrast, people find that in the city they are able to establish and foster productive and prosperous relationships with both life-giving powers and social actors. The logic of the circulatory system and the driving forces of feeding are thus carried into new contexts and places, where urban migrants are able to pursue uniquely Andean notions of progress and advancement better than they can in the countryside. Although the lives of Andean people are changing in ways both substantive and subjective (e.g. in the perception of new possible "horizons" for their lives), the manner in which their goals are achievable continue to rely in part on a customarily Andean orientation that is indexed by feeding. 
Plate $1.1^{8}$

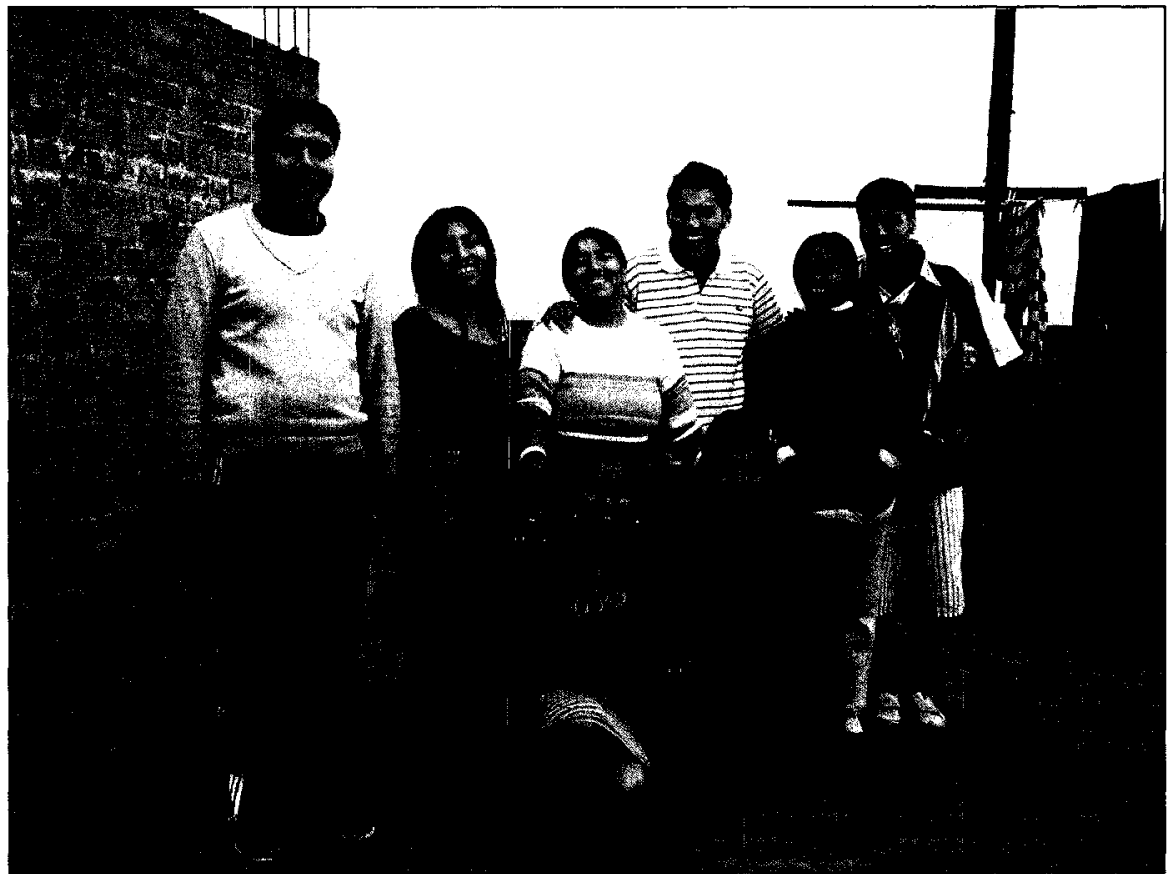

The Bautista family. From left to right: Pedro, eldest daughter, Susana, Yhosef, youngest daughter, youngest son; front row: middle daughter, son-in-law. (Alfonso is absent). Bayovar, San Juan de Lurigancho, Lima, November 2007.

Plate 1.2

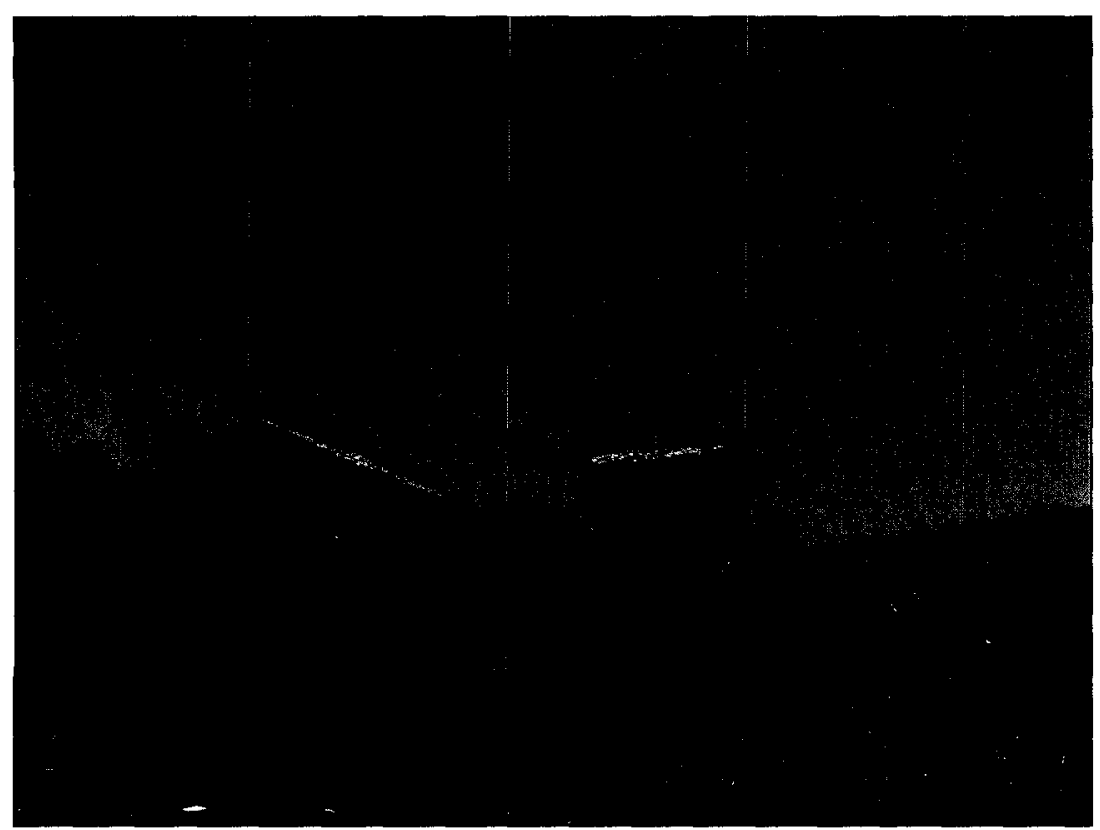

Tía Verónica's house. Paucará, February 32008.

\footnotetext{
${ }^{8}$ All photos are my own unless otherwise noted.
} 
Plate 1.3

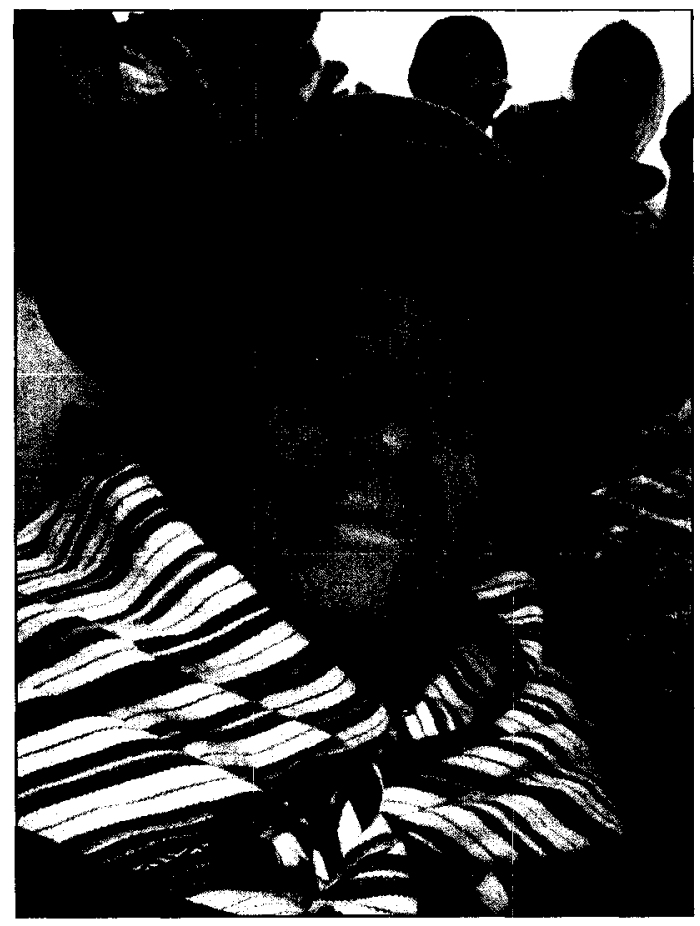

Pedro's eldest sister, Verónica. Paucará, January 312008.

Plate 1.5

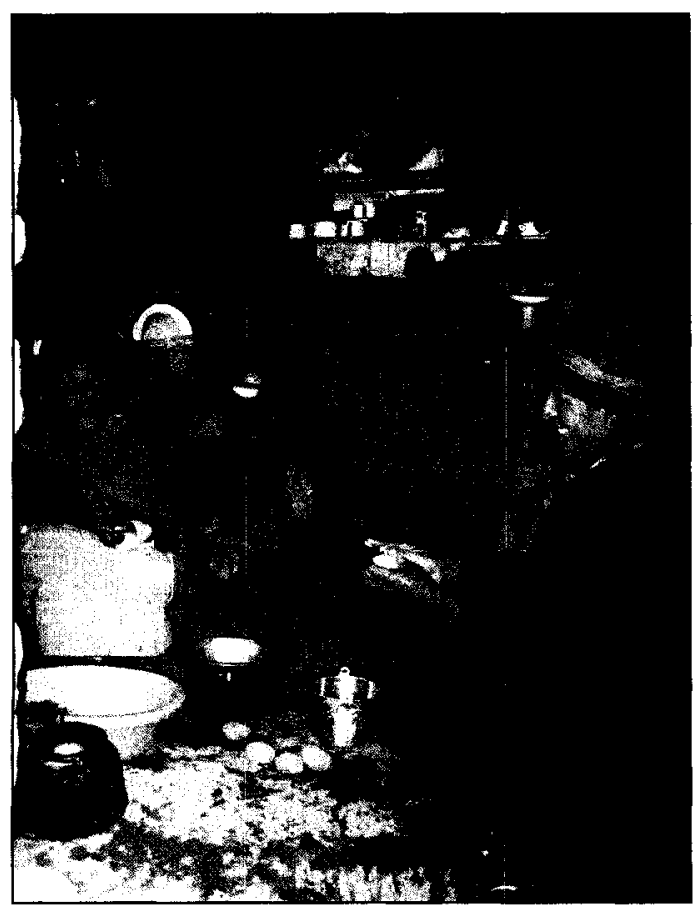

Rosa helps her mother prepare sopa in her kitchen. Paucará, September 2007.
Plate 1.4

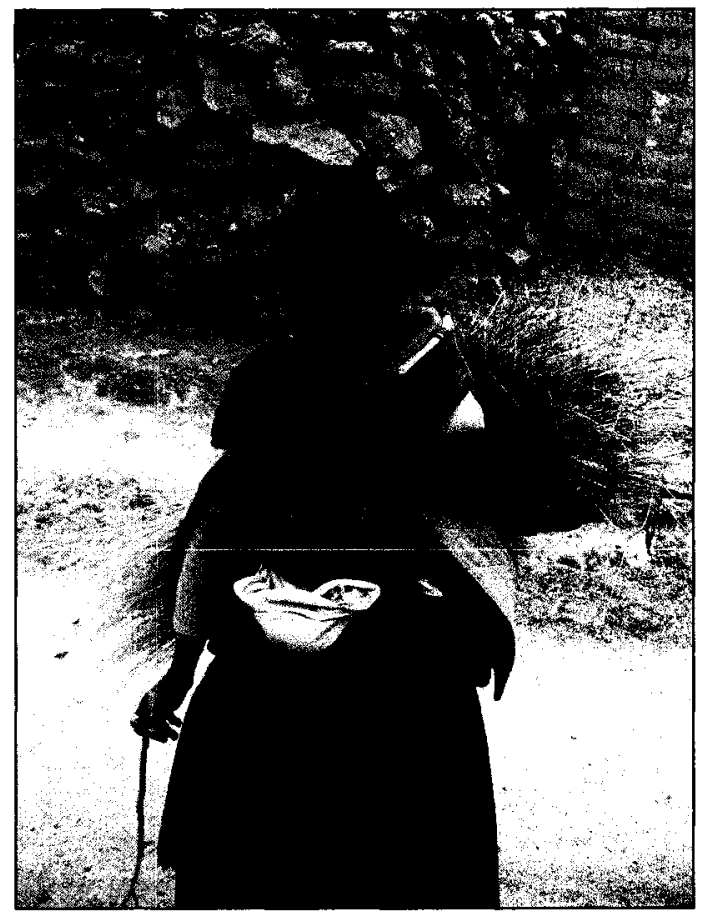

Pedro and Verónica's mother, "Mamaku." Paucará, September 13 2007. 


\section{Chapter 2: Hungry Places and Well-Being}

The phenomenologist Edward Casey says that "places gather things in their midst" (1996: 24) and that this "holding" of landforms, people, experiences, ideas, memories, and practices is what constitutes a place as such in a particular space and time (Ibid.: 24-25). When I first arrived in Paucará and walked through the dry rolling hills with monolithic rocks rising out of them like ancient tombstones or petrified houses, my immediate thought was: this place has voices that speak. Having read so much in preparation, to me the place spoke to several hundred years' experiences and symbolizations of the landscape: pre-Incan ancestral mummies interned in these or similar mountains (remains of which can be seen in a neighbouring valley); Incan roads and invisible ceqe lines that connected distant lands such as this to the centre of the empire in Cuzco; forced labour of los indios in Huancavelica's mercury mines during the colonial period; restructuring of labour and land relations in different periods of republicanism and agrarian reform; and the threat of violence seen under Sendero Luminoso (graffiti from which can still be seen in the surrounding hills).

When people would ask me what I was doing in Peru, I would often give a onesentence summary that included the landscape, agricultural practices, food, and rituals in the highlands. I wonder if placing all these things together in one sentence made any sense to people, particularly with the inclusion of "landscape." Reflecting on it now, I realize that I never heard a campesino (highland peasant) or runa (Quechua person) use the Spanish paisaje (landscape) to describe their surroundings or experiences; what was used was lugar (place). When I became ill upon my first month in the field, key 
informants told me that I "he chocado con ese lugar, con los Cerros" - that I had literally "crashed" with the mountain spirits in that place. Now I am reminded that Catherine Allen stands out in describing the mountain spirits embodied in particular landforms as Places: "Tirakuna are not spirits who inhabit the places, but the Places themselves, who live, watch, and have ways of interacting with the human beings, plants, and animals that live around and upon them"9 (2002[1988]: 26, emphasis in the original).

It is now apparent that for Andeans, landscape is not a relevant issue or category. What is in some way relevant is Place, both in Casey's understanding of Place as a primary category of experience and being in which many things are gathered and held, and in Allen's sense of specific Places with which people have socialized and ritualized relations. What does the place in which my fieldwork is situated "hold" for Paucareños? It is a question that I really cannot answer in any substantive way presently, although I will make an intuitive leap and base my interpretations on the claim that what "speaks" are agential forces embodied in Places by whom people are interpolated. These Places continue to be central to the places that runakuna inhabit - socialized spaces and domains of practice and experience that continue to have certain demands and consequences despite transformations in the lives and practices of people in the highlands.

In spite of my best intentions to investigate the more mundane world of Andean foodways and daily culinary practices, based on the superficially accurate (but banal) observation that food is central to people's experiences and concerns, ${ }^{10} \mathrm{I}$ found myself

\footnotetext{
${ }^{9}$ Allen defines Tirakuna as "Sacred Places," the greatest of which are "addressed as apu, a title of respect meaning lord" (2002[1988]: 26, 277).

${ }^{10}$ Food is central to people's lives in the sense that much of their activity and energy is directed towards procuring and preparing food, but in itself it does not have a privileged symbolic place in other aspects of highland life. More significant is the act of feeding, a theme developed in Chapter 6. However, food and cuisine is remarkably prominent in national Peruvian society, where dishes and food events are often featured in newspapers and on television, and where universities devote exceptional attention to the
} 
presented with totally different (albeit not wholly unanticipated) themes once I arrived in the field. What was indeed of interest to people, at least the family among whom I found myself, were a number of seemingly disparate issues and experiences clustered around Place and the socialized and ritualized relations that people have to it: health, well-being, sickness, and curing; distrust, envy, and social fracture; the further penetration of capitalist markets, the struggle to get by, and urban migration; and the disturbing (to some) popularity of Evangelical Protestantism and abandonment of Catholicism. These themes underscore the layers of emplaced (Casey 1996) history, experience, and meaning in the highlands. ${ }^{11}$

The most obvious starting point for a discussion of place and ritual in the Andes is with the mountain spirits: named, individualized, and autochthonous powers embodied in specific landforms, referred to in various communities as apu (lord), mallku (condor), and wamani (hawk) (see for example Allen 2002[1988]; Gose 2006, 1994; Isbell 1978; Skar 1994). In Paucará, people generally referred to these powers as cerro (mountain), although on occasion they did use the more deferential term apu. Mountain spirits oversee the health, prosperity, and well-being of crops, herds, and households. Ritual offerings made by the householder and directed towards specific mountain spirits as a "sacrifice" or "payment" are necessary to ensure the fertility and productivity of a householder's herds and crops. These offerings are made through an idiom of feeding, and consist of ritual foods such as wine, trago (cane alcohol), chicha (corn beer),

academic study of Peruvian cuisine (for example the Escuela Profesional de Turismo y Hotelería out of the Universidad de San Martín de Porres). The topic may also be more appropriate in communities of urban migrants, where memory, desire, innovation, and "identification" (Brubaker and Cooper 2000) are more overtly evoked in the practice and experience of cuisine in a new place (see Sutton 2001). I personally would like to see an ethnographic study of Peruvian foodways that is not simply about identity, gender, or political economy.

${ }^{11}$ The concurrent emplacement of migrant Andeans in urban locales is a topic that demands further research. See Lazar (2008) for an admirable starting point. 
commercial beer, coca leaves, and specially prepared plants, minerals, and incense.

Particularly powerful offerings are dried llama, alpaca, or vicuña fetuses, which are either burned, buried, or interred in water (Gelles 2000: 89; Gose 1994: 215; see also Allen 2002[1988]; Bastien 1978; Isbell 1978; Lazar 2008; Skar 1994).

The feeding of mountain spirits creates a social context of obligation and reciprocity. In the Andes, feeding is a persuasive way to make a claim on another social actor. To feed someone is to attempt to draw them into a social relationship in which the other is obligated to reciprocate. Reciprocity and obligation are in fact powerful driving forces of production and society in the region. Upon receiving the ritual foods, the mountain spirit is obligated to reciprocate by providing bountiful crops and herds. Moreover, as mountain spirits receive these ritual foods as a sort of "advance payment" (for services which are nevertheless their defining roles in relation to the householders under their tutelage), the "practical consequence" (Alston 1956: 82) is that good fortune and prosperity for the householder should follow. If a householder neglects these ritual payments, the mountain spirit will be angered and retaliate with sickness and misfortune. The re-establishment of the socialized relationship and repayment by the householder are then necessary to regain the favour and benevolence of the mountain spirit.

Since mountain spirits oversee the prosperity and well-being of herds and crops (along with the pachamama, "Earth Mother"), ${ }^{12}$ ritual offerings directed towards them can in some useful ways be thought of as agrarian (and pastoral) rituals accompanying

\footnotetext{
${ }^{12}$ There is some debate in the ethnographic literature regarding whether the pachamama should be described as a monolithic and feminized "Earth Mother." It is possible that its exact use and conception varies from one place to another. The relevant thing here is that Pachamama is an additional divine source of fertility and prosperity that is embodied in the land. Unfortunately its English translation (albeit accurate) probably has it associated in the minds of many readers with quasi-North American Indian ideas about a "Mother Earth" prevalent in Western popular culture. Gose helpfully defines pachamama as a pluralistic "earth source" used to describe "the particular spirit of a named or occupied place" other than a mountain (Gose 1994: 198, 200, 270n15; see also Allen 2002[1988]: 32-33; Gelles 2000: 82).
} 
key agricultural activities such as irrigation, the preparation of fields and herd animals, sowing, hoeing, and harvest. In a general sense, agrarian rituals mediate the relationship between people and the divine powers that ensure the fertility and prosperity of the crops and herds, and the well-being of households and communities. Two common ritual events in the agrarian cycle are herranza (animal fertility rites) and yarqa aspiy (canal cleaning) (see Allen 2002[1988]; Gelles 2000; Gose 1994; Isbell 1978; Mitchell 1991). Different highland communities may also hold yearly pilgrimages to a paramount mountain spirit (Gelles 2000: 57; Allen 2002[1988]: 167-173; Sallnow 1987), a recorreo or boundary marking visiting the mountain spirits surrounding the community (Radcliffe 1990; Rasnake 1986), or special rituals in times of drought addressing the mountain spirits who control water (Sikkink 1997).

Agrarian rituals vary from one place to another, but they generally include t'inkas (libations of alcohol), q'apas or despachos (burnt offerings that include specially prepared plants, minerals, incense, and other ingredients), coca $k^{\prime}$ intus (offerings of coca leaves), and invocations to the pachamama and mountain spirits (both local and distant). As in many Andean festivals, drinking, dancing, and eating also feature in events ranging from one day to a week or more. Some, like yarqa aspiy, are community-wide ritual events involving sponsorship by mayordomos (fiesta sponsors) elected to hold a cargo office (see Gelles 2000; Isbell 1978); others such as the herranza and t'inka rites held throughout the year more directly concern the household (see Allen 2002[1988]; Gose 1994). These household rites may concern the sowing of each field, harvest, personal cattle and other herd animals, the household in general, and special needs that may arise, such as illness (see Gelles 2000: 81). 
According to my informants, the herranza is the most important agrarian ritual in the department of Huancavelica, where the main event takes place on the Feast of Santiago on July 25. In a general sense, the herranza is an animal fertility rite in which families bless their cattle, horses, sheep, llamas, and alpacas with new cintas (ribbons; that is, earring tassels and necklaces), and give ritual offerings of trago, chicha, and coca leaves to the mountain spirits and pachamama in celebration and blessing of their herd animals. It seems to be generally associated with the end of the dry season and the beginning of August (Allen 2002[1988]: 140; Gose 1994: 90-91, 194-196; Isbell 1978: 138; Mitchell 1991: 136). Sian Lazar suggests that this time of year is appropriate to such ritual offerings because "the harvest is over and the earth is still open and particularly hungry" (2008: 151). The ethnographic literature indicates that in many communities, more than one herranza (or t'inka rite) occurs throughout the year. In some areas these fertility rites are additionally associated with the Feast of San Juan on June 24 (Allen 2002[1988]: 140; Isbell 1978: 155), Carnival in February (Allen 2002[1988]: 140; Gose 1994: 194-196; Isbell 1978: 138, 154-155, 164), and with the Feast of San Marcos on April 25 (Gose 1994: 194-196).

Due to logistical difficulties (a teacher's strike blocking the roads, full buses, ignorance of alternative routes) I was not able to travel to Paucará for the Fiesta de Santiago. However, I was fortunate to have been invited to visit the family farm of neighbours of the Bautista family in Lima, who are from the nearby department of Junín. On the afternoon of July 24 I piled into a taxi with Lucía, her grown daughter and young grandson, and Yhosef my translator, the eldest son of don Pedro Bautista, to a bus station 
in Lima from where we took an overnight bus to the provincial capital of Chupaca, close to the departmental capital of Huancayo.

We arrived in Chupaca early on the morning of July 25 . The morning air was crisp and cool; steam rose from the carts of street vendors selling emolientes (fortified herbal drinks) to people on their way to work; and a line of women with their large baskets of various pancitos (little breads) were setting up in front of the fruit sellers and other vendors in the marketplace. Lucía bought a large bag of candies, fruits, and juices to bring to the festival (gifts bolstered by the bulging bags she and her daughter had brought from Lima, probably full of food and clothing), and after a breakfast of chancho con pan (roast pork with bread), relished by my fellow travelers, we set out to find a taxi to take us to the farm outside of the hamlet of Chucupata.

It was my first time entering the highlands, and by mid-morning I was beginning to feel the effects of altitude sickness, marked by a grogginess and general disorientation that developed into a strong headache throughout the day ("Drink it off," I was encouraged by my hosts). I do remember twisting roads through the dry rolling hills (approximately 4000 masl) and a strong sun in a cloudless sky as we arrived outside of the farm and walked up the steep hill from the dirt road with our various bags. When we arrived at the farmyard, we were greeted by Lucía's elder brother Maurelio, his wife, and their sons and other family members. They were surprised and excited to see a gringa come to their home, and they were remarkably welcoming and enthusiastic during my brief but intense stay with them.

I was immediately offered a bowl of caldo de mote, a sheep-broth soup with large kernels of fresh corn that is traditional to the Fiesta de Santiago. I rested for an hour or 
more while the family continued their preparations. I was encouraged to visit the ruinas de los antiguos (Incan ruins) further up the hill, but despite my interest I simply did not have the energy to set out to find them (one of many regrets in retrospect).

The celebrations began in the early afternoon in the shade of a tree outside the farmyard in one of the family's enclosed rocky pastures. In this first leisurely session, people chewed coca, passed around small glasses of commercial beer and other drinks (wine, trago, cañaso), and shared the occasional cigarette. While it is polite to shake out any remaining alcohol before passing the glass on to the next person, I did notice one individual quietly and purposefully pouring some beer onto the ground before taking a drink. This was in fact the only time I observed this "offering to pachamama" (see Skar 1994: 111; also Allen 2002[1988]). Meanwhile, adult family members prepared the colourful cloth cintas for the cattle and sheep. Flores, small bundles of $i c h u$ grass and two other plants, were also prepared to stick in the band of each person's hat.

After about an hour, people started moving towards the cattle contained in the pasture. The women called to the cattle by beating on tinyas, small round drums, and singing songs typical of Santiago in celebration of the animals. ${ }^{13}$ The men used ropes to catch the cattle around their necks, and carefully removed last year's earrings and necklaces to put on new ones (earrings for the cows and necklaces for the bulls). There were ten or so in all, and they probably included the cattle of more than one nuclear family (including those of Maurelio, one of his grown sons who lives beside him, and another sister or other female relative), as well as any cattle "left in the care" of family members by those who have moved to cities such as Lima or Huancayo. After all the

\footnotetext{
${ }^{13}$ See Skar 1994: $65 \mathrm{n} 11$ on the power of wailing and crying to bring people back; I suspect a similar force is at work here with the falsetto singing of women to call upon sources of fertility (bulls, which are often associated with mountain spirits, and the pachamama more generally) (see also Gose 1994).
} 
cattle were attended to, Lucía took her bag of sweets bought earlier in the day, and threw the candies, bottled juice, and fruit onto the cattle. Children and adults alike enthusiastically ran after the treats.

The Bautistas later told me that in Paucará, where there are less steep hillsides and some large open fields, the cattle are first "called" with women beating tinyas and men blowing long horns. When the cattle are gathered, men compete to chase them down, grabbing their horns with their bare hands before putting on the cintas, which is said to be more "exciting" and "emocional" than simply roping them in. The man who catches the most bravo (fierce or brave) bull gets a premio (prize) of a necklace of fruits, sweets, and breads. All the cattle also get such necklaces, as well as a feeding and sprinkling ( $t^{\prime}$ inka) of matchka de maíz (presumably a drink of toasted, ground corn).

With the cattle taken care of, Maurelio and his family made their way towards a lower courtyard beside the sheep pen. A second drinking and coca chewing session ensued, by this time becoming more spirited, including dancing to recorded Santiago music playing from a stereo. The family was entertained by dressing me in a pollera (skirt) and having me dance with each of the three grown sons.

In this session, the coca chewing became somewhat more focused, with people going around to give each other a handful of coca leaves from their little plastic bags, as well as passing around cigarettes. People also began preparing coca $k^{\prime}$ intus, which consisted of four unblemished leaves of similar size. I was told that the $k$ 'intus were for the Cerro. They were collected by one of the women, and Yhosef later told me that around midnight that night, Maurelio and his wife would take the coca $k^{\prime}$ intus to the Cerro overlooking the farm and offer them to the pachamama by placing them in the 
ground, along with a sprinkling (t'inka) of white "wine" (probably chicha de kiwicha or de jora), in order to ensure the fertility of the cattle in the coming year. It explicitly has to be done at night when the pachamama will be able to receive the offering.

According to don Pedro and his wife Susana, in Paucará this offering or recomendación ("advice," a term which don Pedro always used, perhaps in the sense of seeking divine advice) to the powerful Cerros occurs at midnight on July 24. Householders perform t'inkas, bringing chicha de kiwicha (kiwicha beer) or chicha de jora (corn beer) to the various fields on which their animals pasture, and making the offering to the Cerros in the name of the animals. This they described as apoyo or aid to look after the animals and to augment the herd's numbers.

Meanwhile, family members prepared the cintas for the sheep and necklaces of fruits and breads to be worn later by Maurelio and his wife. After about an hour, women again took up tinyas and everyone moved closer towards the sheep pen to replace the earring tassels on each of the sheep. As with the cattle, this was carried out by Maurelio and his grown sons, with the addition of Maurelio's wife. The older children also had great fun trying to catch the sheep. I am told that in Paucará, this is how boys "earn" their trago, and one of Maurelio's grandsons (of about 10) proudly asked for his photo to be taken afterwards with his drink.

After all the sheep had their cintas renewed, Maurelio and his wife were adorned with the fruit and bread necklaces earlier prepared. The pen was opened up and the sheep were herded into an enclosed pasture higher up. As the sheep moved through the entrance to the pasture, Maurelio sprinkled them with chicha using a handful of branches. Once all the sheep were in the pasture, this bowl of chicha became the focus of everyone present, 
who got down on all fours, "baa-ed" like sheep, and with great jest jostled to take a drink from the bowl. I was prompted to do this as well, and everyone laughed when I had my face pushed into the chicha. Yhosef later told me that this was to "dar saludos a Pachamama," "like when you say thanks to God on your birthday for a good year," and to ensure the fertility of the sheep.

The Bautistas described the entire month of July as the "birthday" for the animals, the time of the year when they are specifically celebrated and blessed. In Paucará, in the week before the Fiesta de Santiago families are busy preparing special foods (such as caldo de mote) for July 25 . During the evenings, they are visited by neighbours or visitantes who travel from house to house singing songs of Santiago and chakchando, chewing coca together. The visitantes visit each house but in the spirit of "negative reciprocity" (Sutton 2001: 57-58) they also steal a little meat from the kitchen. These preparations are also preceded by the Fiesta de San Juan on June 24 (which is also the national Día de los Campesinos), when there is an additional fertility rite for sheep. All the young lambs have their throats lightly cut; the blood is collected, mixed with trago de coca or aja (chicha), and drunk by all the family members. This is also said to augment sheep numbers.

The herranza concluded with a final, more formal, coca chewing session on a manta (woven blanket) in the pasture, with the adults making coca k'intus and singing songs of Santiago. Regrettably I did not stay until the end, as I was feeling quite ill and had to lie down. Yhosef returned from town with some painkiller for my headache, which I took with a herbal water that Susana had prepared for me before leaving Lima. It seemed rude to drink this in front of everybody (but I thought it best not to mix 
painkillers and alcohol, the only other liquid that seemed to be available), so all the children got a taste.

Yhosef also brought back a case of beer on my behalf to give to the family. I had unthinkingly arrived without anything to give my hosts, and I was mortified by the thought of not reciprocating their generousity in any way. The beer was enthusiastically received, and in fact initiated a more formal connection with Maurelio, who offered me a lamb in return and declared us compadres. He said that he would keep the sheep for me and that I had to return next year when it would be grown and they would slaughter it. (He also invited me to return August 30 for the day of Chucupata's patron saint, Santa Rosa de Lima, which I was regrettably unable to do).

Within an hour I was prompted to come to the fiesta that was beginning in the house of Maurelio's son. This seemed to be a time especially of family celebration and solidarity (two grown sons as well as Lucía and her daughter had returned from Lima or Huancayo for the occasion), and several hours passed with much drinking and dancing to the Santiago music playing from the stereo. As night drew on under the small covered porch, those too tired to dance (including children) sat on blankets, sheep skins, or chairs. The fiesta ended sometime before midnight, with everyone having their fill of beer, trago, coca, and cigarettes.

Everyone slept in the next morning, and after warming up in the sunny courtyard for an hour or so to shake off the chill of the night, we began walking down through the family's chacras (fields) to the town of Jarpa, about an hour away, to catch a colectivo to Chucupata and then on to Huancayo. It started to drizzle rain just as we were getting our 
bus tickets, and I thought that the closest roads to Maurelio's farm must surely be impassable come November.

Not all ritual offerings directed towards the mountain spirits are specifically concerned with agricultural production or prosperity, however. As indicated above, there are also a number of household rituals concerned with the health and well-being of herd animals and household members in general. These are "cures" or "recomendaciones" made to specific mountain spirits as well as malevolent diablos, devils associated especially with pools of water, the wind, and night. T'inkas, despachos, and other offerings and "payments" are made to these forces upon the consultation of a curandero (folk healer or ritual specialist) when a family member or animal falls ill.

My first encounter with threats to one's health and well-being posed by emplaced powers occurred within the initial month I spent in Paucará. Near the end of September I fell ill with an earache so intense that I had to return to Lima. Some people told me that the earache was for the wind (hence their constant admonishments to cover my ears); others said it was because I had washed my face in cold water. The Bautista family was convinced that if it was not for the diablo on the wind or in cold water, and if I had not fallen asleep in any fields where a diablo could enter me, then it was the "Place" that was "chocando" (crashing, conflicting) with me. If the earache continued (i.e. after taking a prescription from the pharmacist), I would have to bring an offering to all the Places I had visited in Paucará to ask for forgiveness.

The most likely of these Places was Cerro Huallanca that sits along the Río Wichjana, where I had gone to wash clothes with some young cousins a couple of weeks earlier. This powerful mountain spirit is described at once "like a god" and as a "demon." 
It is in fact the "god" or "saint" of the Danzantes de los Tijeras (Scissor Dancers), renowned in Huancavelica for their distinct footwork accompanied by a rhythm tapped out while holding shear-like scissors, their acrobatic moves, and dangerous feats such as piercing their skin with knives and swallowing swords. While individuals with the proper offerings, oraciones (prayers), and faith may address Huallanca to be "baptized" a Danzante de los Tijeras (thereby gaining the "power" to perform the dance), he is threatening to others to whom he is not known, and whom he may cause to fall ill.

Huallanca is also the abode of a gentil with a rich mine. Gentiles are described as "old people": antiguos, primitivos. Don Pedro and Susana told me that they are the ancient survivors of an immoral "First Age" destroyed by God. They were irredeemably envious and selfish, and for this they had to be destroyed. Burned with the heat of two suns, they were driven underground and into the mountains, where they now guard their hoards of gold. Huallanca is said to be hot at night, "como fuego" (like a fire) because there is the gold of the gentiles inside. If one tries to mine this gold, one will be killed by Huallanca, unless one brings the payment of another human life for permission to mine there. No one in his right mind would try to mine this mountain, but still people know that there is gold there because "Huancavelica has a lot of mines."

This ambiguity of the mountain spirits can also be seen in a second example. One evening in November a curandero came to Tía Verónica's house where I was staying outside of Paucará. Apparently he was the younger brother of her deceased husband. In the late afternoon he arrived with his wife, a bowl of soup waiting for them both, to perform a cure for one of Verónica's grown daughters living in Lima. She had been suffering from an eye infection of some sort for six or more years, which she contracted 
before she had left for the city. Several cures had been attempted in the past, but they had not succeeded because the curandero (probably not the same one) had not found the correct Cerro or diablo that was causing her sickness. This night a curandero would try again.

Earlier that day I had walked to Paucará with Verónica to buy the necessary supplies: a bag of coca, a small bottle of trago, a pack of cigarettes, and five or six white candles (as well as oil, sugar, noodles, a little bread, and some juice and fruit for her daughter Rosa who was tending her sheep). “QQué falta?” Verónica rhetorically asked as we were walking out of town. "Solamente maíz." (What's lacking? Just corn).

As the darkness came on, the floor of Verónica's small sleeping quarters was full of the guests sitting on sheepskin rugs and wrapped in blankets: the curandero and his wife, Mamaku (Verónica's elderly mother who lives nearby), and myself. Everyone chewed coca for a half an hour or so, their own coca bags bolstered by the coca Verónica passed around. The curandero, his wife, and Mamaku conversed in Quechua while Verónica prepared things according to the curandero's instructions.

The large framed picture of Jesus was brought down and seated beside him, along with a folded manta and the six candles, which were lit one at a time throughout the night. The curandero brought out from underneath his jacket a small framed picture of Jesus as well as a large crucifix on a rope, which were placed on the manta. Verónica brought an empty 2-litre plastic bottle, the trago and cigarettes, two clean sheets of writing paper, and a cloth-wrapped plate containing three cobs of dried maize, a packet of white sugar (in contrast to the less processed sugar normally eaten), and a white rock called "llampu." 
Verónica told the curandero of her daughter's condition and how it had appeared. Had she walked by a particular puquio, small pool of water? Or perhaps something happened when she had been pasturing sheep on Calvario, a sizeable flat-topped mountain that is the abode of that powerful Cerro overlooking her house. I unfortunately do not really know.

The curandero counted off the kernels of maize in pairs as he dropped them onto the plate. Once he had reached a 100 or so, he brought the plate of kernels to the kitchen with Verónica, where they were ground along with the sugar and llampu in the mill. This "flour" was brought back in two packets formed out of the paper, and they were emptied into the plastic bottle, which was full of "raw" (crudo), unboiled water. The flour and water was shaken a bit and set to the side.

Everyone sat around talking quietly and chewing coca until two in the morning, with the curandero drinking the trago and smoking the cigarettes. I confess that I fell asleep, so I must have missed when the flour-water was emptied into a nearby puquio (pool of water) or pacha (earth), as Rosa later told me should happen. This flour-water is "la comida del diablo," the food of the devil. The curandero is to bring this food as "payment" to the diablo or pachamama that is making the patient sick. The diablo will eat this, and in a day the person should be cured. If the person is not completely cured, the diablo has "mucho hambre" (much hunger) and needs a second serving with a repeated curing. The next morning Verónica told me that her daughter was helped but not completely cured, and that she would require another curandero.

Sickness may sometimes be the cause of particular mountain spirits that are embodied in specific mountains, but at other times caused by diablos that live on the 
wind without form: disembodied, unseeable. According to Rosa, "Ese diablo vive en aire no más, pue[s] en cualquier lugar está diablo" (That devil lives on the wind no more, so in whatever place is the devil). A person may encounter a diablo, such as a voice calling to follow them in the middle of the night. Drunks or fools who follow these voices will be led to a hueco (hole) or cerro (hill) where they will be killed by the diablo. Similarly, one may be called or encantado (enchanted) by a sirena (mermaid) abiding in a pool of water, especially those accompanied by rainbows (see Tomoeda 2005).

Individuals who are attacked by a diablo sometimes die within a few days, and at other times may waste away for years, their life force slowly draining, before they become aware of their problem. For example, Rosa's husband became so ill after they moved to Lima that he was hospitalized for over a year while Rosa worked selling food on the street and caring for their three young children. Fearing death and distrusting the medical doctors who "couldn't help him because they didn't believe in diablos," they moved back to Chacapampa (about a 10-minute walk outside of Paucará) where they now live. When they consulted a curandero, they learned that he must have been attacked while sleeping on hillsides as a child. They made the appropriate offerings and now he appears to be totally healthy.

Rituals directed towards mountain spirits therefore may be either of a productive or health-related nature, but they are always in some way about well-being. "Being well" is about more than health and contentment; it is also about being able to get things done (e.g. raising crops and animals, maintaining the household, accessing a social network) and relating to wider social spaces (e.g. one's subject-positions in the family and 
community vis-à-vis local power hierarchies, civil society, and the state). The mountain spirits are involved in people's lives in these various aspects.

In their benevolent element, the attention of the mountain spirits is necessary to "get things done" in the highlands. These powers are at times capricious (see for example Allen 2002[1988]) and will punish those who either circumvent proper ritual engagement or to whom they are not known; but with proper ritual feeding (payments of consumables), they will ensure that one's crops and herds are bountiful, that one's family is healthy, and that one's household is maintained. Yet as mountain spirits slip into the demonic realm, gentiles and diablos threaten and seduce with a hunger that is not altogether the same. It is not a hunger which drives something onward, much like a tinku (a confluence of forces or encounter of two agents; see Allen 2002[1988]: 176-178; Gelles 2000: 99, 185n4), but one which leaves the victim weakened and drained of their life force.

Gentiles are associated with the same Places as mountain spirits, but a distinguishing feature of diablos is that they are without form or embodiment. Yet diablos are far from placeless: any pool of water, strong wind, or the obscurity of the highland night could conceal a malevolent diablo abiding in it. This very elusiveness is a part of their threat. Like other menacing figures such as the ñak'aq or pishtaku (extractors and sellers of peasant fat; see Crandon-Malamud 1991; Kato 2005; Orta 2004; Spedding 2005), they are emplaced in highland communities that exist in interaction with urban centers, larger markets, the state, and other segments of Peruvian society. Emplaced powers such as diablos and mountain spirits speak to the experiences of runa vis-à-vis these elements, a theme which will be developed further in the following chapter. 
Plate 2.1

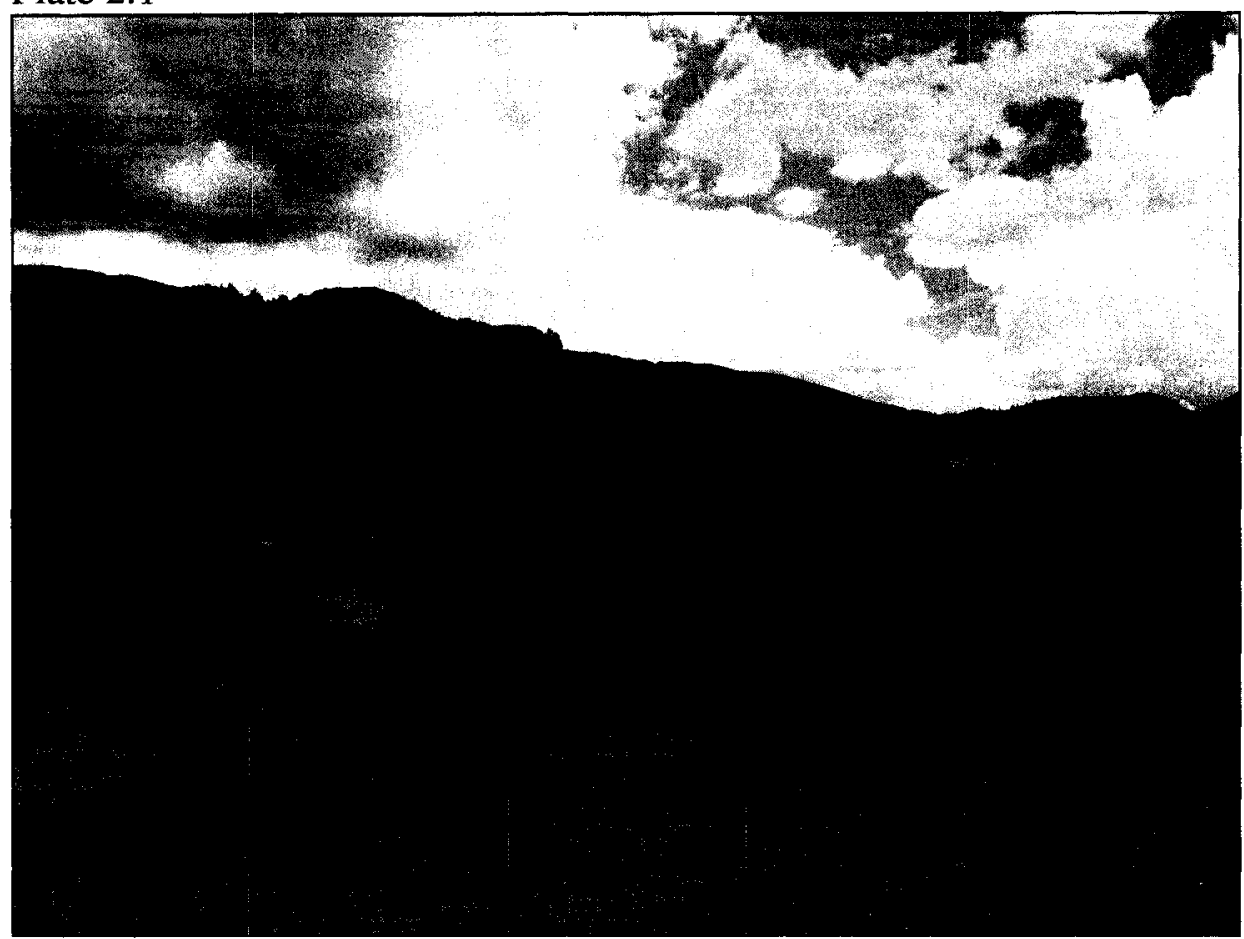

A view of Bautista family lands, looking towards the town of Paucará. September 2007.

Plate 2.2

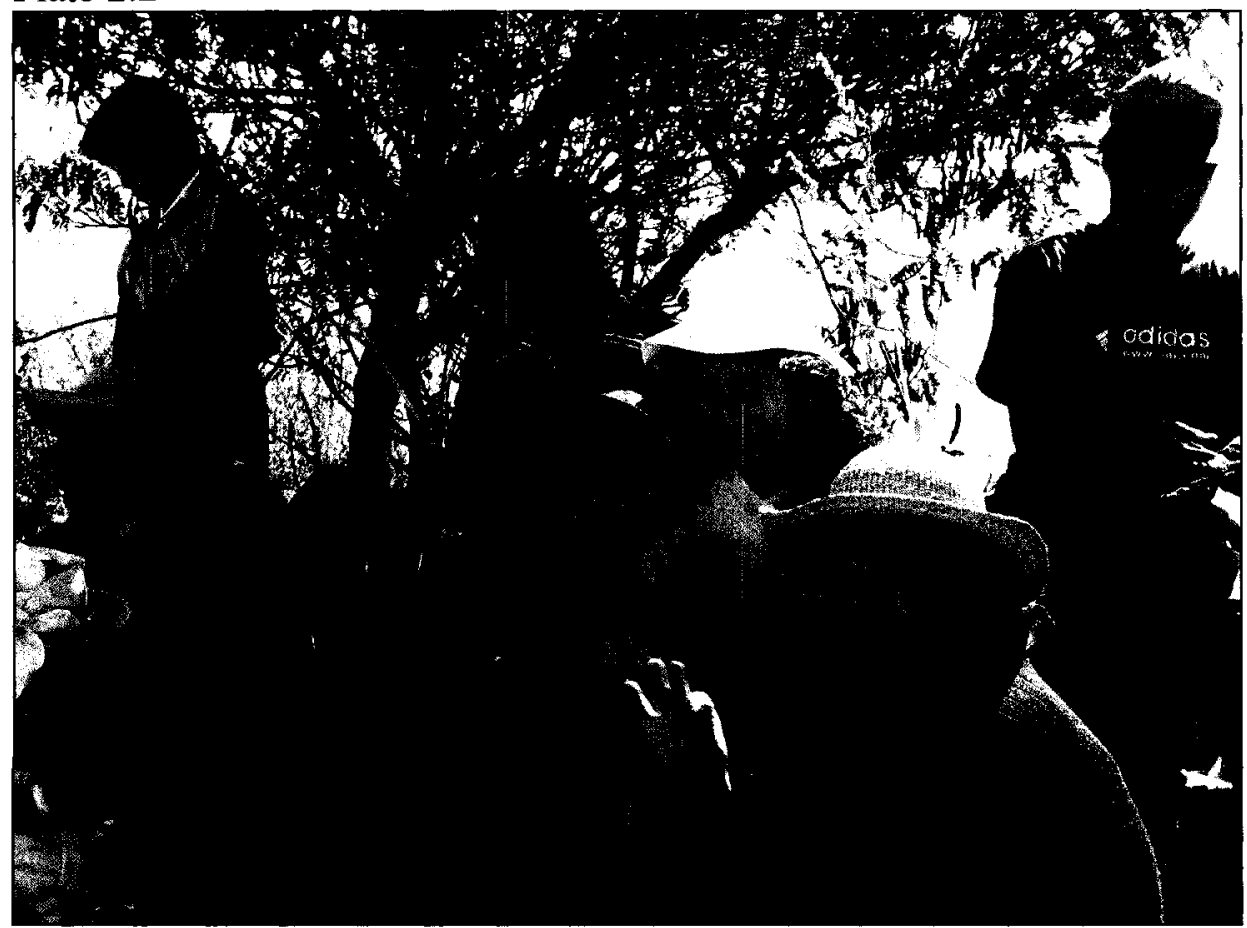

The family prepares for the herranza: cintas, flores, and coca $k$ 'intus for the cerros and pachamama. Pedro's neighbour Lucía at the right with her daughter and grandson. Chucupata (Junín), July 252007. 
Plate 2.3

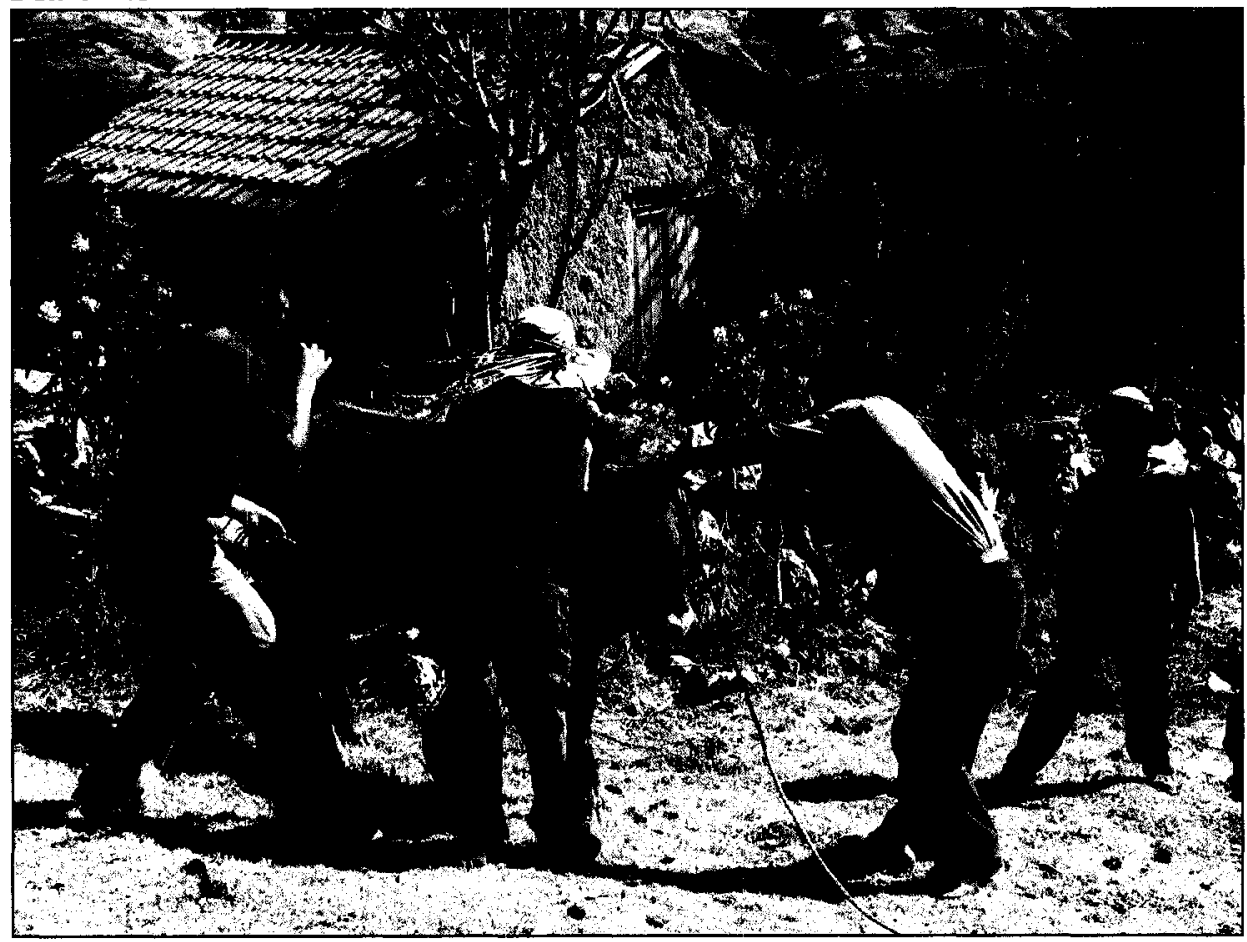

Men use ropes to catch the cattle. Chucupata (Junín), July 252007.

Plate 2.4

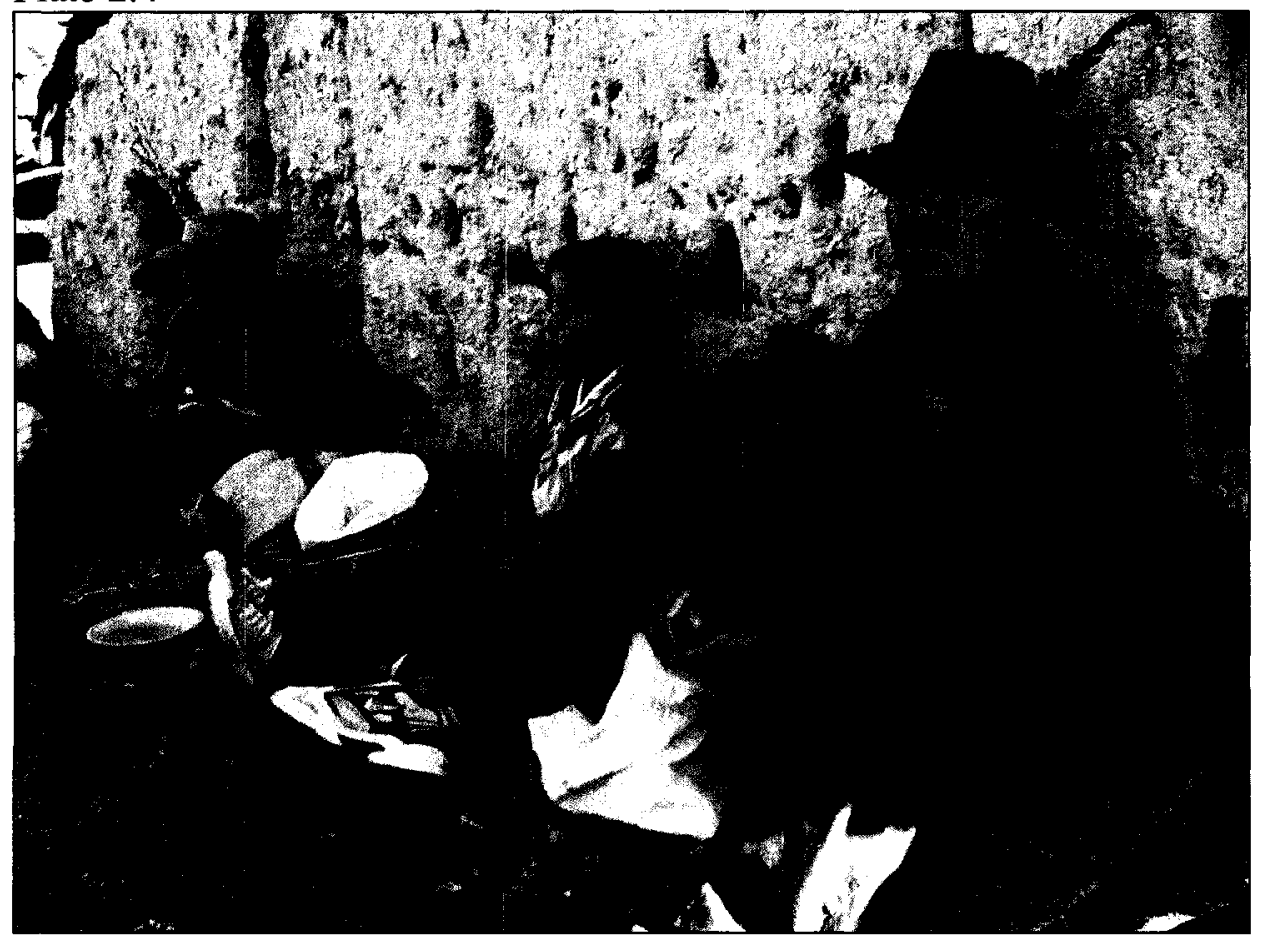

Maurelio chews coca, with his wife and grandson to the left. Chucupata (Junín), July 25 2007. 
Plate 2.5

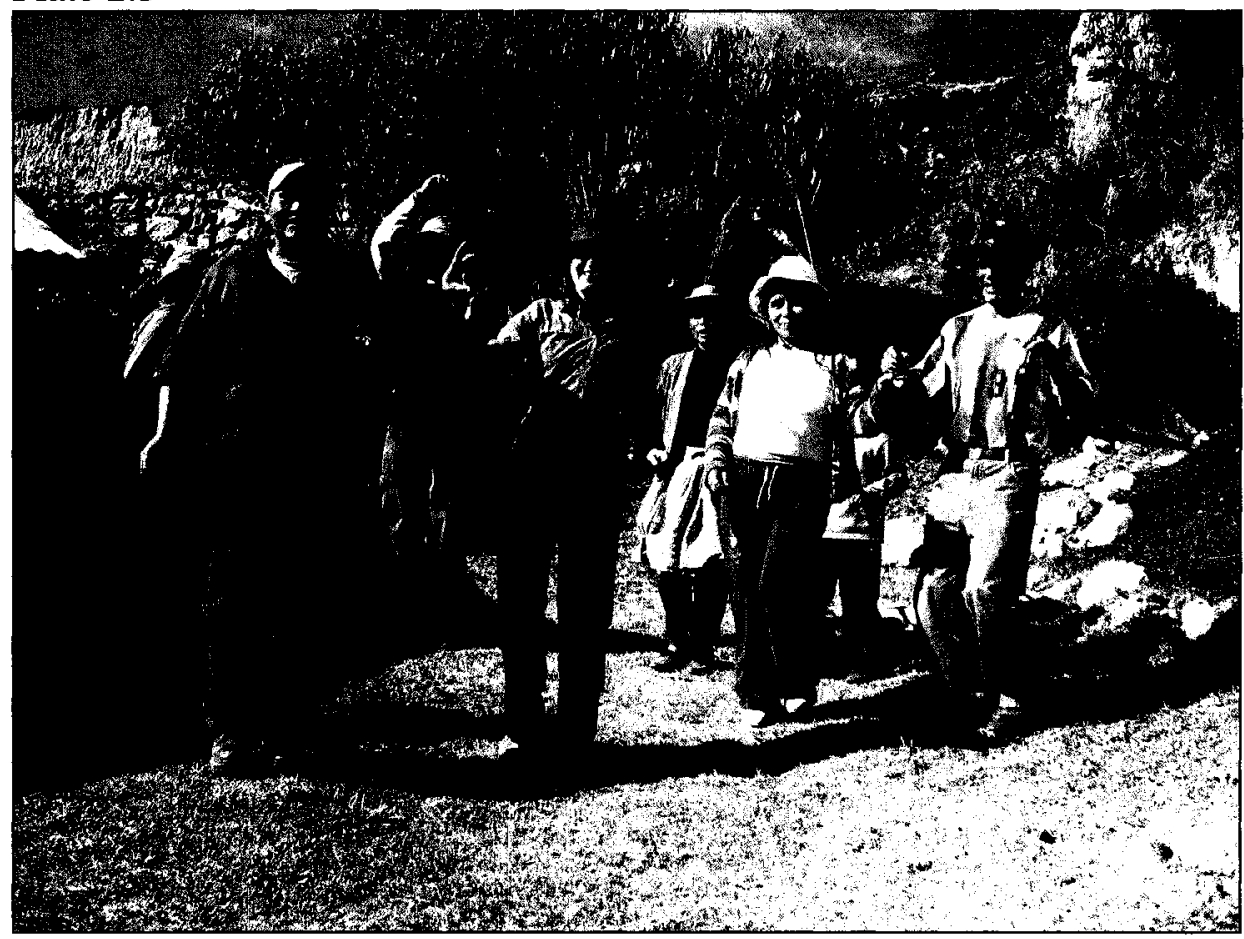

The family drinks and dances after completing the herranza for the cattle. Chucupata (Junín), July 252007.

Plate 2.6

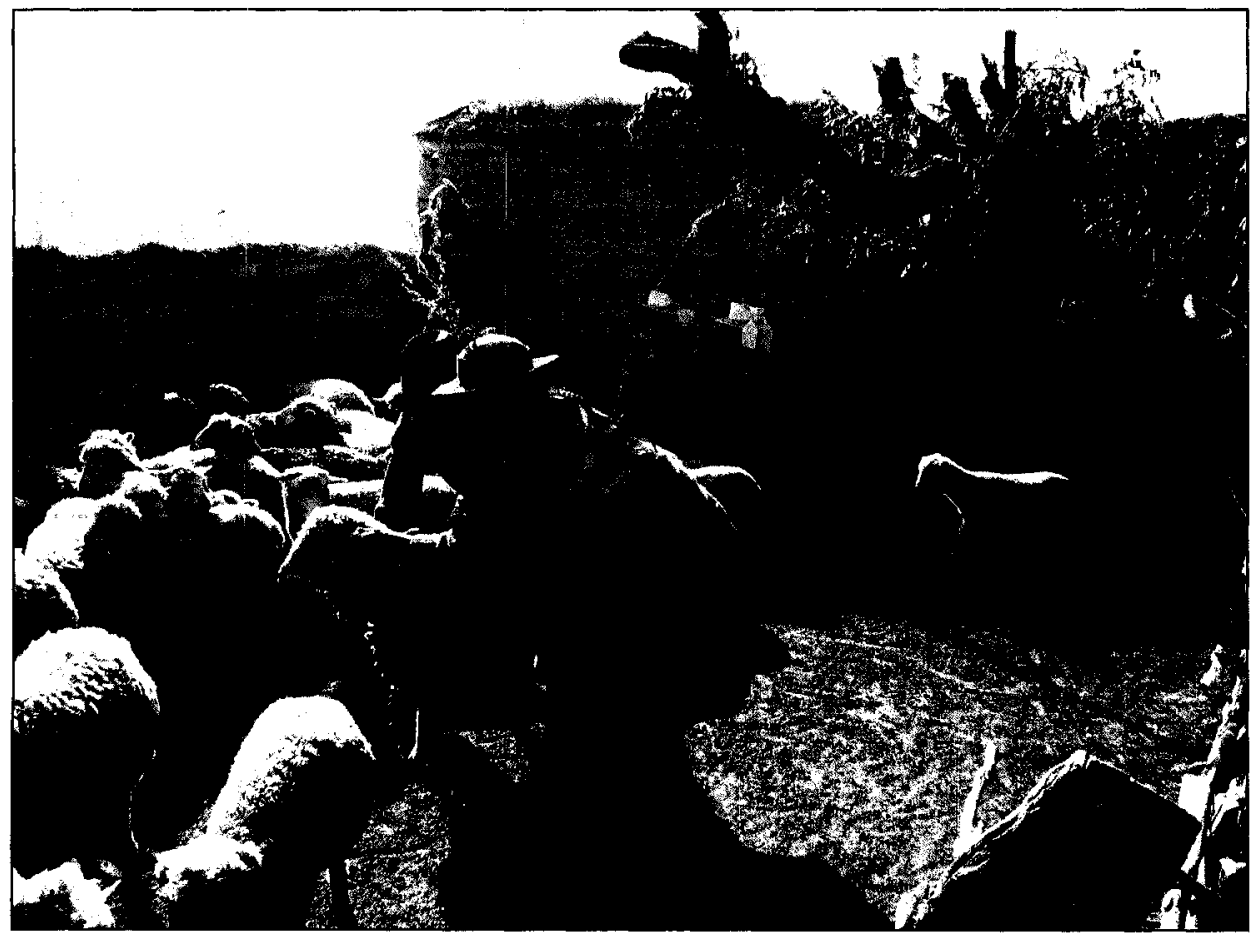

Maurelio and his wife catch the sheep in their corral. Chucupata (Junín), July 252007. 
Plate 2.7

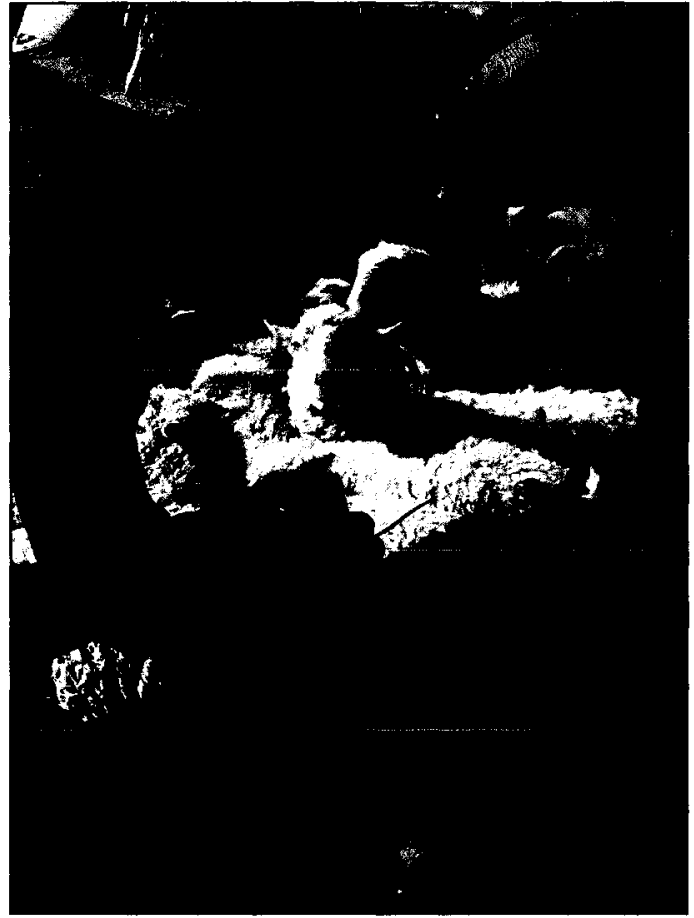

Renewing the cintas on a sheep.

Chucupata (Junín), July 252007.

Plate 2.9

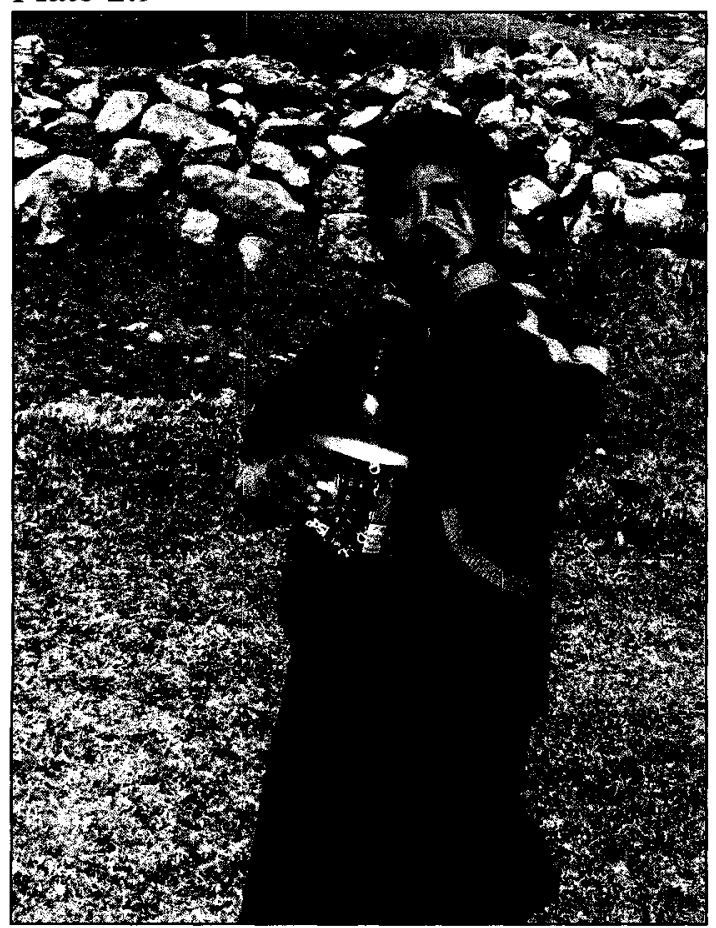

A young boy earns his trago. Chucupata

(Junín), July 252007.
Plate 2.8

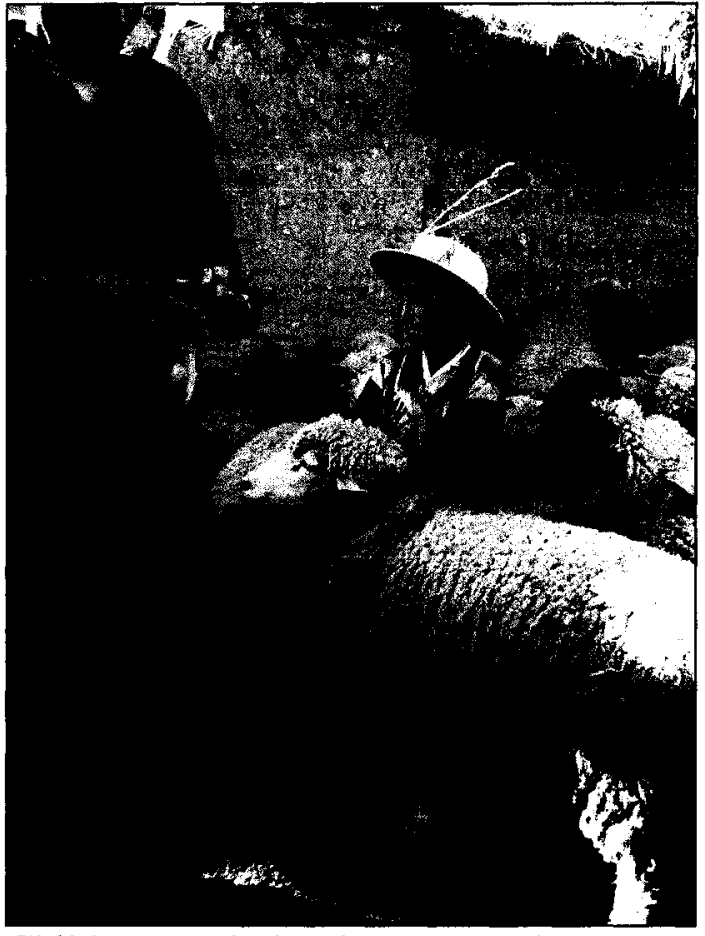

Children catch the sheep as well. Chucupata (Junín), July 252007. 
Plate 2.10

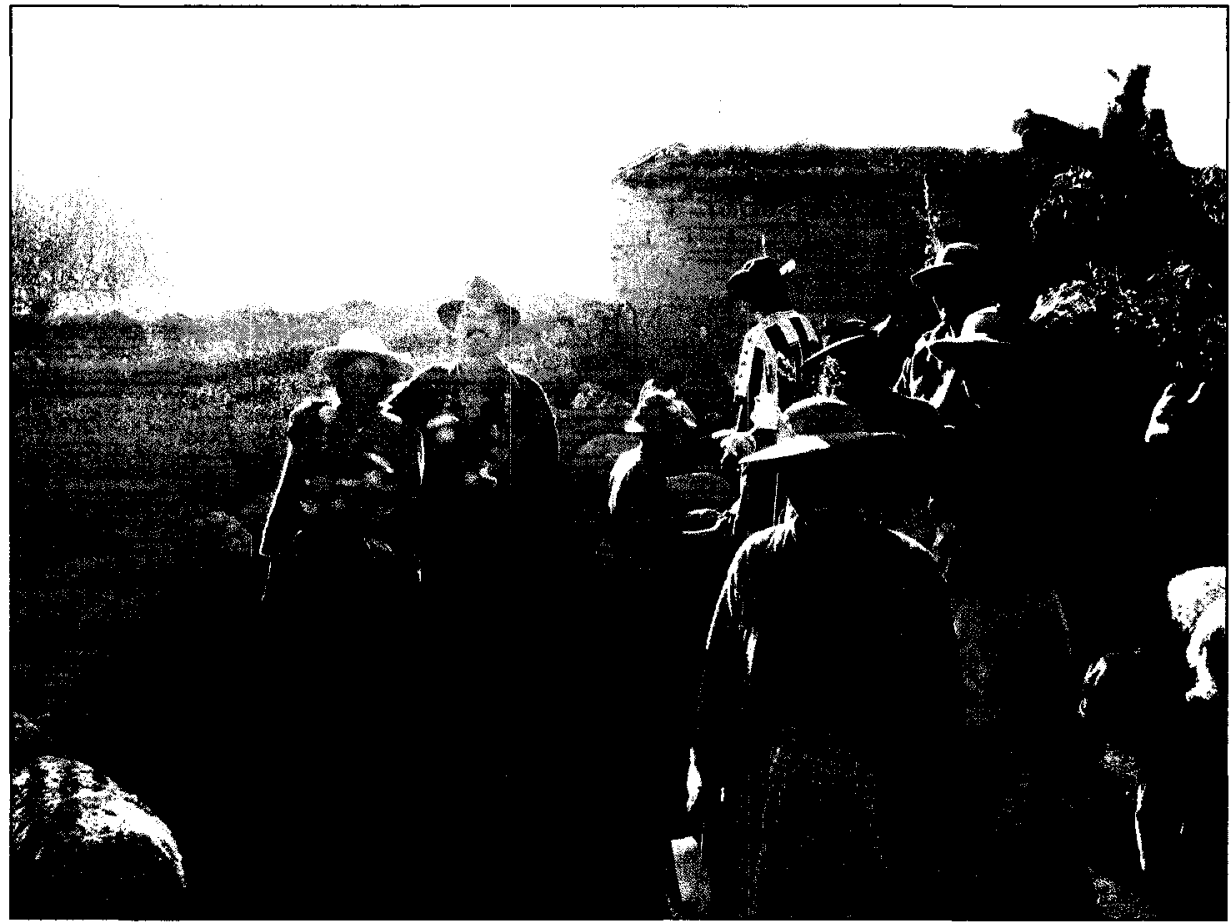

Maurelio and his wife are adorned with necklaces of bread and fruit after completing the herranza for the sheep. Chucupata (Junín), July 252007.

Plate 2.11

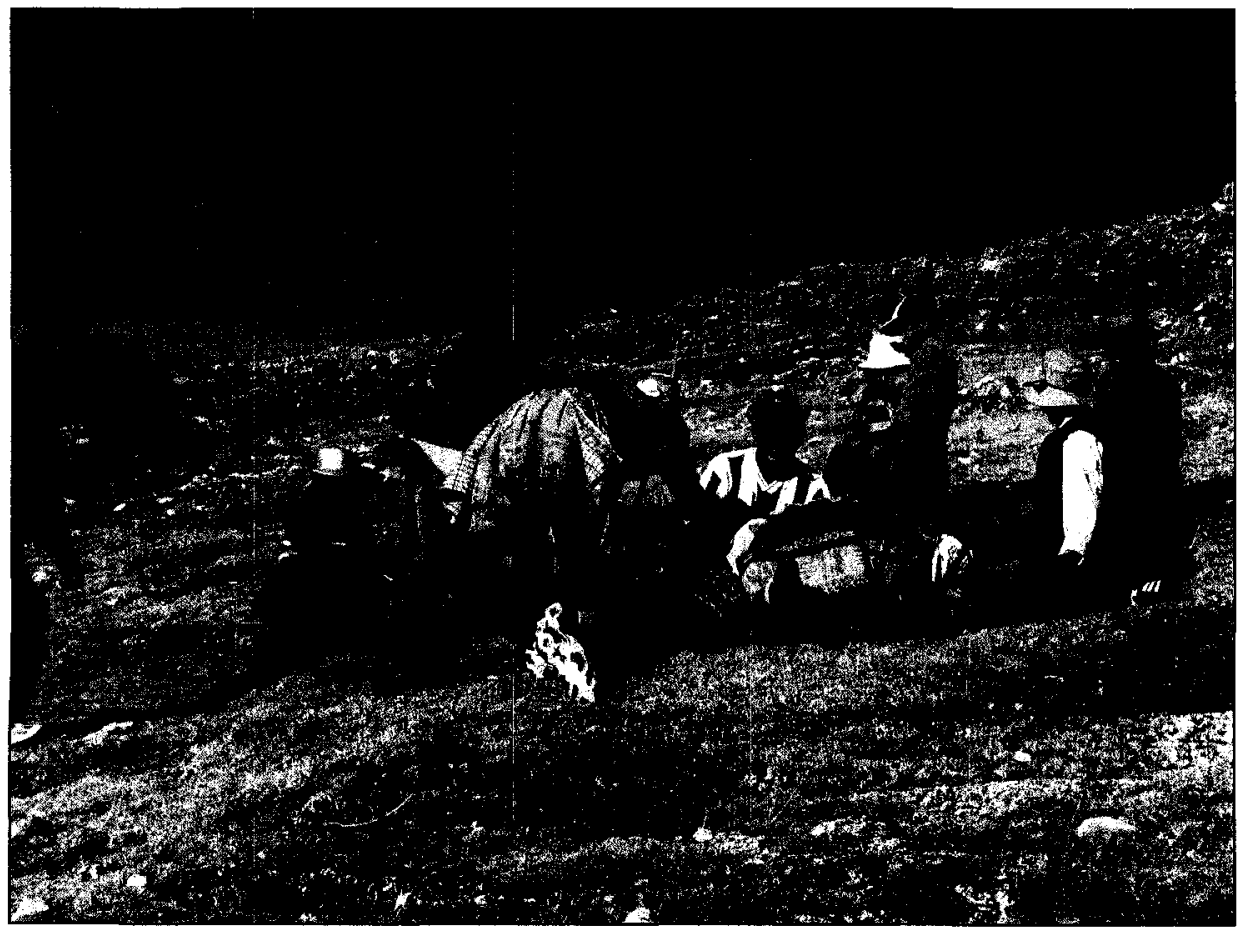

Everyone got down on all fours and baa-ed like sheep to drink the chicha. Chucupata (Junín), July 252007. 
Plate 2.12

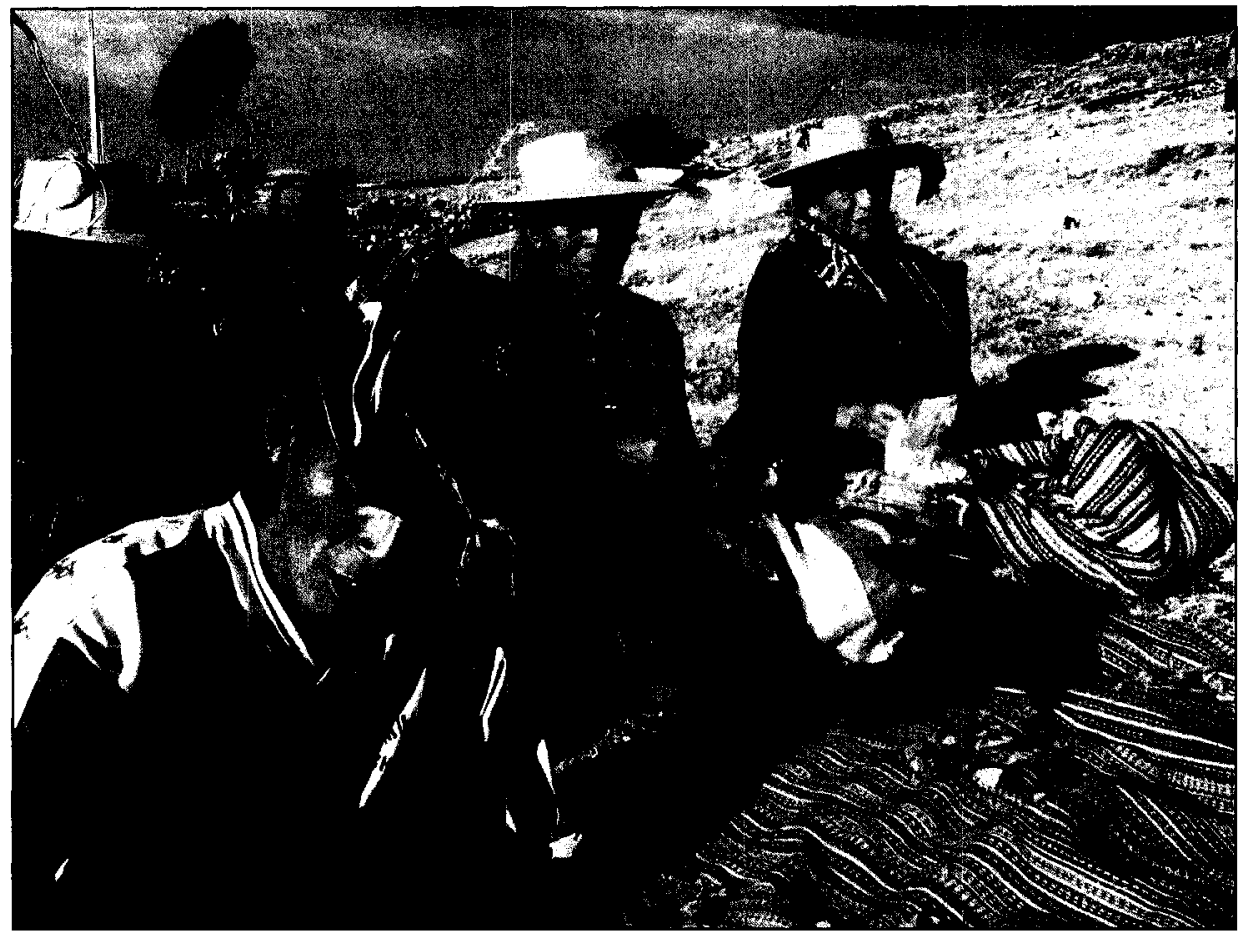

Chewing coca and singing songs of Santiago as the herranza is completed. Chucupata (Junín), July 252007.

Plate 2.13

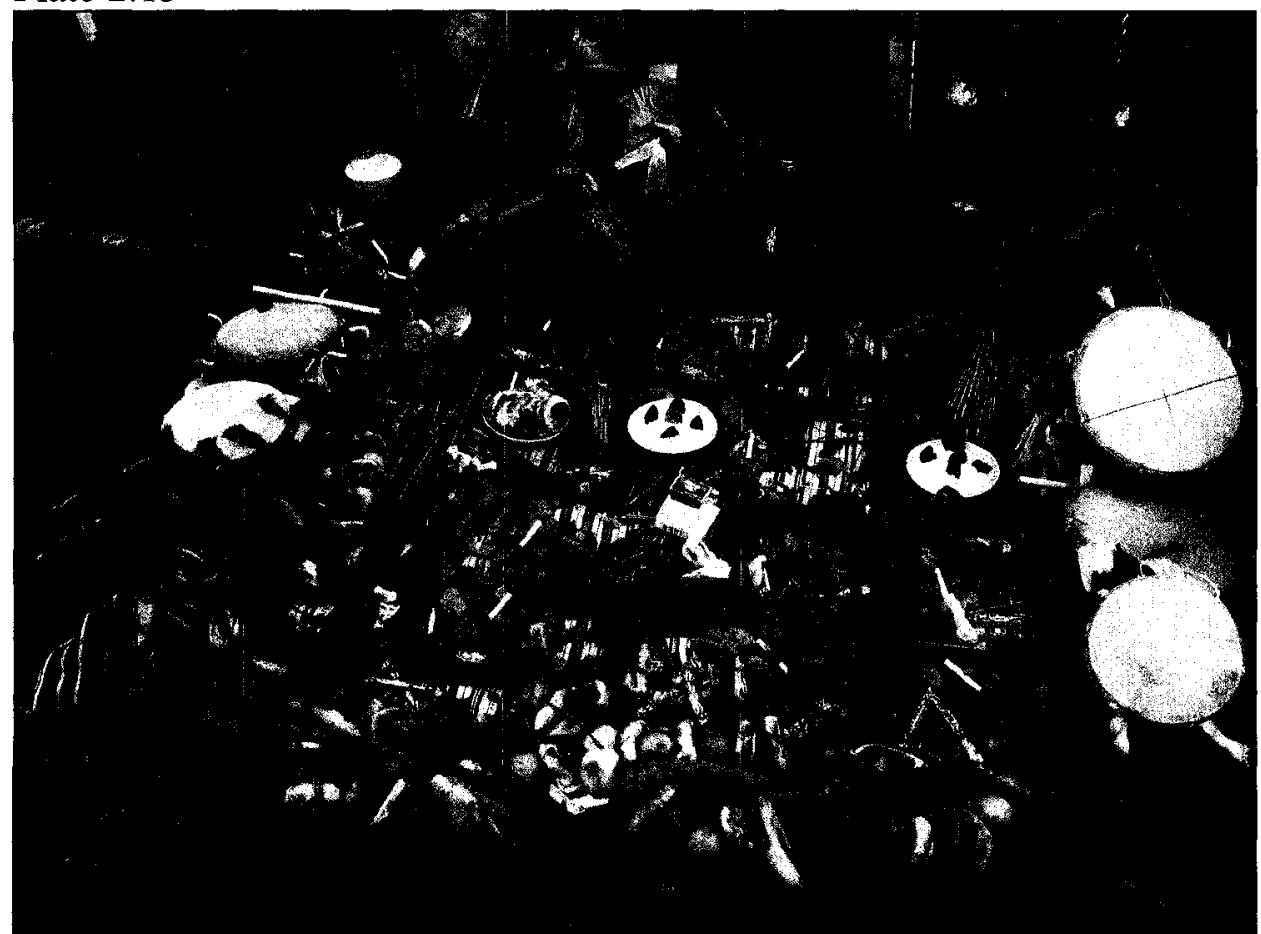

Ritual mesa for the Fiesta de Santiago. Note offerings of coca, chicha, wine, commercial beer, and cigarettes, as well as tinyas, flores, and necklaces of bread and fruit. FIPA, Lima, August 12007. 
Plate 2.14

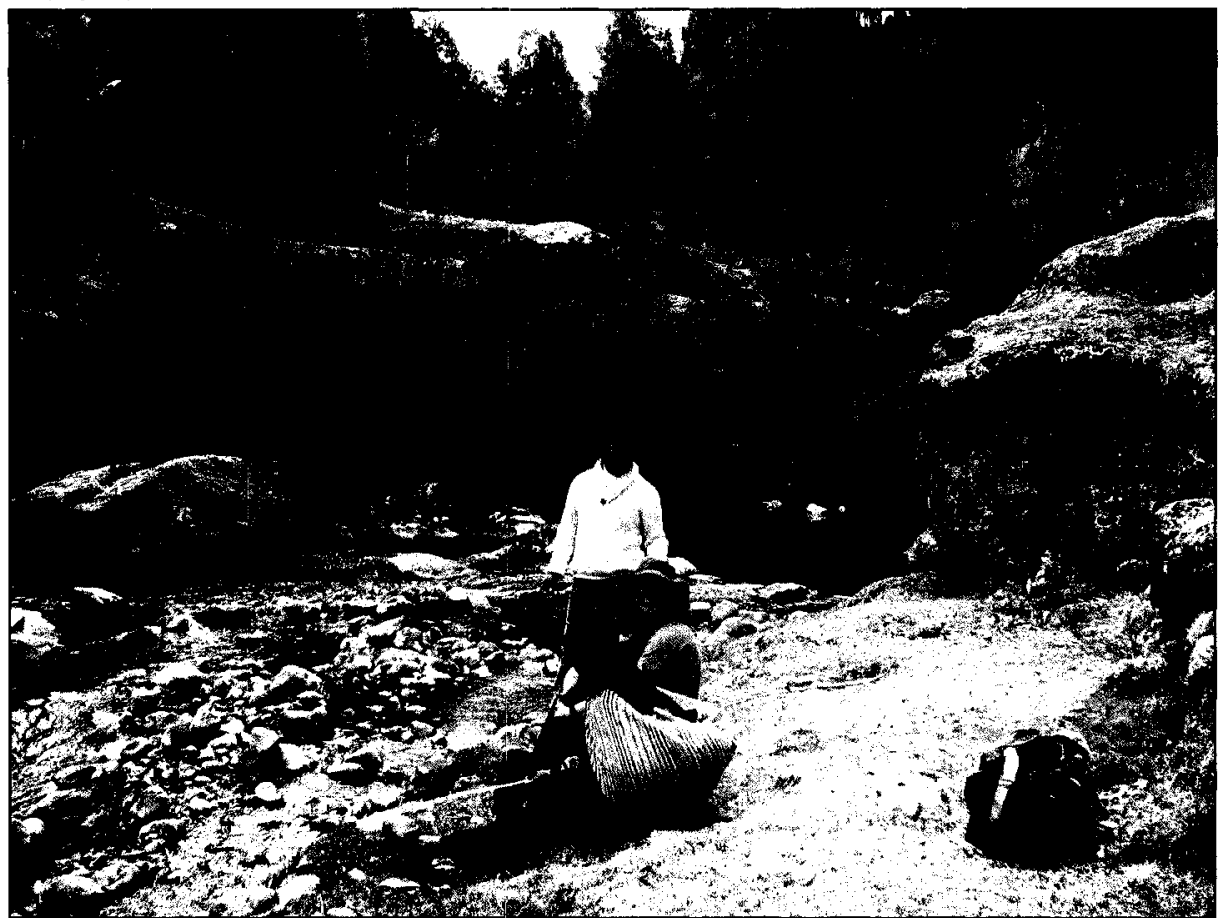

Preparing to wash clothes in the Río Wichjana with daughters of Gladys and Teofilia. Paucará, September 152007.

Plate 2.15

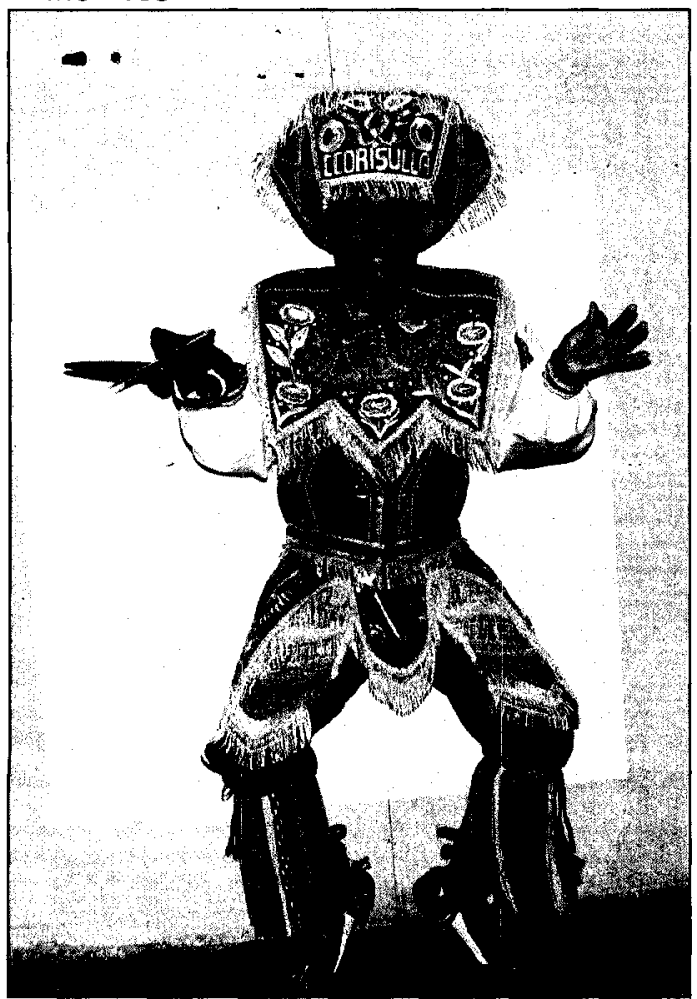

Don Pedro in costume as a Danzante de los Tijeras (early 1990s family photo).
Plate 2.16

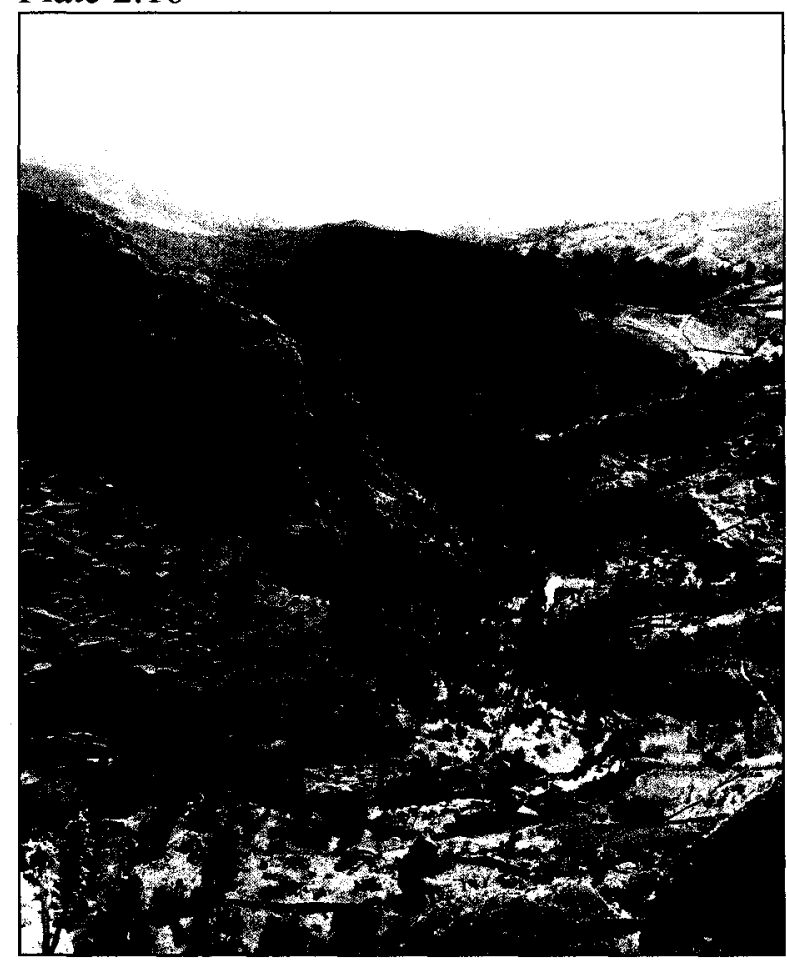

Cerro Huallanca with the Río Wichjana at its base. Paucará, November 2007. 


\section{Chapter 3: Movements and Exchanges}

"Don't come down the road from Paucará at night," warns Verónica's sister Teofilia. Is she referring to the same road I walked in on? It hardly looks like even the most ambitious driver could manoeuvre a vehicle through the narrow dips and turns. "I saw a car with black windows there the other night. It stopped by a man on the road, they asked who he was; they were looking for someone. They tried to take him in the car, but he got away. Don't go, except during the day. It's not safe." Later as I walk along this road with Susana, she warns me not to stop to rest where the spire-like outcrops form an enclosure of sorts, obscuring one's view to the town and the fields along the road. "Here we don't stop. Someone could jump out from behind one of the rocks. Or a diablo could enter you." This is the same Cerro that was said to threaten Susana's father who once attempted to build a house at its base. A hideous horseman exited the mountain at night, threatening that if he didn't move the house from his "doorway," he would be killed.

When I departed from Lima, a city officially of 8.5 million (INEI 2008: 18) full of movement, contrasts, and seemingly imminent danger, and arrived in the comparatively sleepy district of Paucará, the highlands initially appeared quiet and safe. I soon learned, however, that the lives of runa are also filled with movements, contrasts, and threats lurking on apparently tranquil pickpocket-free country roads. These threats could originate from a capricious mountain spirit, a jealous gentil, a malicious diablo, an envious neighbour, or even a shadowy remnant of Sendero Luminoso. 
From an outside perspective, the highlands are characterized by the remoteness and isolation of communities inhabited by poor, uneducated, and "backward" campesinos who remain steeped in their traditional beliefs and practices. But this ethnocentric stereotype does not reflect the complex and modern reality of the highlands, where even remote communities long have had enduring economic and social connections to other towns and larger urban centres (see for example Collins 1988; Paerregaard 1997; SalazarSoler 2006; Skar 1994). Andean communities actually exist in a dynamic space that does not adhere to the implicit dichotomy of modern/urban and traditional/rural. Rather, people are simultaneously emplaced in multiple locales in which a number of competing and not necessarily commensurable priorities, needs, desires, and beliefs coexist.

As a district capital and market centre, Paucará is an ideal location for investigating the connections between the countryside and city that are integral to Andean people's lives and experiences. It is a quite sizeable town (population 3,830 in 2005 [INEI n.d.]), with several paved streets, many stores and services (including three popular internet cafés), two schools, a hospital, two bus lines with daily departures for Huancavelica, Huancayo, and Lima, and taxis to take people to any nearby town. It has a major weekly market that draws many vendors and customers from the surrounding area (allegedly, Paucará's feria is more popular than that of the provincial capital in nearby Acobamba), and stores offer foods and small goods from nearby settlements as well as other departments everyday.

Paucará is accessible by bus and taxi, although its relative proximity to major centres still entails a lengthy journey by Canadian standards. For example, from Lima one first has to take a series of city buses from one's home to the small Los Libertadores 
bus station in La Victoria (close to metropolitan Lima proper), a journey of about two hours in itself from San Juan de Lurigancho. For S/. 25 one can get a seat on a relatively comfortable bus (more in times of increased demand, such as for festivals, or if one is traveling with extra baggage). Those wanting to save money could show up at the last minute to buy abandoned seats at a slightly reduced rate, or even buy a much cheaper standing space in the aisle (a surely unsafe and illegal practice, but common enough for the very poor on the journey from Paucará to closer destinations on the way to Lima).

The bus for Paucará leaves every day at five o'clock in the afternoon, making its way out of Lima on the Panamerican highway south (a rare double-lane paved highway) before heading east through the mountains, winding its way on ever less developed roads to Paucará (making numerous stops along the way), to arrive at 5:30 the next morning. It is also possible to make a somewhat longer but better-paved journey from Lima to Huancayo, and from there take another bus or taxi to Paucará. There is also a train that runs from Lima through Huancayo and then on to Huancavelica, although it is less commonly used. One can also travel by bus to Huancavelica, and from there take a colectivo taxi to Paucará (S/. 10 for two hours on dirt roads).

The first time I made the journey from Lima to Paucará at the beginning of September with Susana and Yhosef, it was still quite cold. We brought blankets to keep ourselves warm during the night on the unheated bus, and we passed by some snowylooking lakes in the high puna. Susana and Yhosef also armed themselves with cotton balls and rubbing alcohol for their ears, and Susana blew smoke into my ears for the wayra, to stave off the threats of the wind. When we arrived in Paucará, there were already taxis and young porters with wheelbarrows waiting for a transport job from 
travelers. We were able to avoid their services and simply walked to the house of Susana's cousins in town, knocking on the door and waking them up to rent a room for the morning as nothing was yet open (which seemed remarkable to me, considering that Susana arrived unannounced after not visiting for seven or so years).

The bus is also the primary mode in which packages are sent between family members in Lima and Paucará. I still do not know if and how the national postal service reaches such highland districts; my informants have never sent a letter in the mail and tell me that the bus is the only way (see Skar 1994: $81-82$ on general suspicion of the postal service and written word in Matapuquio). For example, I used Los Libertadores to send a large Christmas package from Lima to Tía Verónica and the other family in Paucará: a panetón, or Italian Christmas cake, and evaporated milk, chocolate, and sugar to make hot chocolate for each family - the most coveted Christmas "treat" - along with school supplies for Rosa's children and some money for her and Verónica. On the Sunday before I sent the package, I made a call to one of the public telephones in Paucará and asked for Rosa. Her food stall is nearby on this day, and someone at the telephone was sent to retrieve her. I told her that a package would be arriving and asked her to deliver the panetones and chocolate caliente to her mother Verónica, her grandmother Mamaku, and her aunts Lidia and Teofilia.

Short of actually traveling, this sort of indefinite phone call is the only form of direct communication between family in the city and the countryside. Verónica and Rosa lamented that weeks or months would pass without news from Lima, for communication was sporadic and unpredictable, and before Susana and Yhosef visited and left cell phone numbers, they had no way to reach them. News of spread-out family members is also 
carried indirectly through a series of individuals who have regular contact with one another. For example, Rosa's eldest son lives with the family of her brother (Verónica's eldest son) in Nueva Esperanza, and through Manuel's periods in Lima news of them reaches family in Paucará; a good three hours away on city buses lives another of Verónica's daughters, fairly close to don Pedro and the Bautista family in San Juan de Lurigancho, through whom news of the rest of the family occasionally arrives.

"Paucará could have been Cuzco, but Calvario disobeyed the Inca," Manuel tells me. Months later, don Pedro's brother-in-law Jaime recounts the same story. "The Incas were powerful; they could move things where ever they wanted. They could move mountains to make room for good maize fields." There were three mountains to move: Harani, Cruz Kuna Paka, and Calvario. The Inca threw a rock in his sling to move the first two, but when he threw his rock at Calvario, it only nicked the top off the mountain, which now can be seen lying a short distance away. Calvario stayed where he was, and so Cuzco was built in another spot. Cerro Calvario is so powerful that he could refuse the wishes of the Inca; now Paucará is impoverished and unimportant, although in other situations (such as bull fighting), Paucareños are proud of their brave, fierce, and even obstinate character. The story leaves me with the impression that Paucareños wish they could be greater than they are, and hope if they could only move in the right ways now perhaps they can be.

Paucará is surrounded by smaller towns and hamlets where many people maintain their households through a combination of subsistence agriculture, pastoralism, and 
migratory labour. On many farms I visited around Paucará, it appeared that women, school-aged children, and the elderly remained to take care of the family farm (mostly pasturing sheep and caring for other animals), while men and older children left for cities such as Huancavelica and Lima. Men return for times of planting (September-November) and harvest (April-June). Families with any financial means send their children to cities for secondary or post-secondary schooling, where many elect to establish themselves more permanently. Alternatively, older sons may join their fathers shining shoes or performing odd jobs during periods of migratory labour, and unmarried daughters may seek employment as cooks and maids for wealthy urbanites.

For example, of Mamaku's six grown children, two sons and one daughter live in Lima. Three daughters remain farming outside of Paucará, with their husbands working in the city part of the year and their grown children already establishing their own families in Lima. Like Mamaku, Verónica and her two sisters are more or less content to continue living where they have always lived, although they depend to a certain extent on the monetized labour of household members (migratory husbands, selling food at the weekly feria) and remittances sent home by grown children. They use the money for items they cannot obtain through barter: basic staples such as sugar and cooking oil, household expenses such as school fees and medicines, and the occasional luxury such as a new hat or shawl. Obviously households in which both spouses are alive and productive are better off than those in which one is widowed, as is Verónica. For her, the absence of all but one of her six children (Rosa) is a great hardship, because she has a more limited family network to draw upon for help and companionship. 
Verónica's brothers and remaining sister living in Lima also have various degrees of economic security. One son has a dry-goods store, but the others maintain their households, as most urban migrants in Peru, by selling goods or performing a service on the street as ambulantes (street vendors). They recognize that moving to the city has not necessarily improved their situations, although they certainly have access to a host of consumer goods, bodily comforts, and economic and educational opportunities that their rural relatives do not. These amenities diminish in significance, however, when one continues to live day-to-day with little resources for the future or in times of exceptional need. Don Pedro even went so far as to advise his nineteen-year-old son Alfonso, who is underemployed and starting his own family, to return to the family farm to take up the lands that they still own, ${ }^{14}$ because "at least then you would have something to eat." (This was not an option seriously considered by Alfonso, however, who was eight or so when he left Paucará, and who is happily accustomed to city life).

Andean people's lives and experiences are complicated by their enduring economic, social, and sentimental connections to their communities of origin and the desire and need to access the cash economy and opportunities that the countryside does not afford. From an outside perspective they (especially migrants) may seem to be "betwixt and between." Nothing in what I have observed or heard indicates that Paucareños experience themselves in this way, however. As Karstsen Paerregaard has noted, people are not necessarily compelled to make their lives into cohesive wholes; their "conceptualization of social life" may be "incomplete and fragmented rather than

\footnotetext{
${ }^{14}$ Some of these small fields (generally less than one hectre) sit abandoned or may be used by family members as pasture; other fields are "rented" out to an unnamed Paucareño not directly related to the Bautistas. This person had failed to pay the rent for some time, however, and in 2008 don Pedro expressed an intention to sell these fields.
} 
holistic" (1997: 21). Shifting and fluid identifications and strategies may be experienced as just different aspects of the same life rather than dissonance and incommensurable fragmentation borne of reified essentialisms (see for example Lazar 2008: Chapter 5). Rural campesinos and urban migrants alike employ various social and economic strategies in order to survive and even improve their situations. Mestizo markers such as Spanish competency, education, access to cash, and urbanity may be taken up without total acculturation or the abandonment of typically Andean practices such as reciprocity or ritual engagement (see Paerregaard 1997: 19), thereby allowing the integration of "diverging life-styles and world views into the whole of Andean culture" (Paerregaard 1997: 21).

This analytical orientation enables one to see Andeans as "cultural innovators and the creators of new identities" (Paerregaard 1997: 21) in a contemporary context in which they are "confronted, more intensively than in the past, with many forces of change which are inexorably transforming the countryside" (Zoomers \& Salman 2003: 3). People may change and adapt as they move to urban centres, and widen their perspective as they visit or encounter people from other regions. But they also keep what "really matters" to them. Despite working in or moving to cities, people continue to be interpolated by mountain spirits who are the driving forces behind production, fertility, and well-being, as well as gentiles and diablos who prey upon hapless runakuna. Thus it continues to make sense to consult a curandero in Lima, for example - and many migrants from Paucará or elsewhere who are "in the know" do in fact visit don Pedro (who is a curandero) for a consultation or ritual cure. ${ }^{15}$

\footnotetext{
${ }^{15}$ Don Pedro on occasion also performed such ritual baths for tourists that his son Yhosef brought to their home. He charged a fee of approximately S/. 100.
} 
Yet for some, it is difficult to leave the countryside even though they want to. Rosa was fifteen or sixteen years old when her father was hit and killed by a bus in Lima during a period of migratory work. As Verónica's eldest child, she traveled to Lima to send remittances home from her employment as a household cook and maid (where she learned how to write her name and cook criollo dishes). After she married her husband Manuel (also from the district of Paucará), they started to set up a household in the city. Her five brothers and sisters also followed, probably living at first with their aunts and uncles already in Lima.

Although Rosa and her husband are both from poor peasant backgrounds, they evidently dreamed of improving their family's situation through education and wage labour in the city. Although by her own account they were compelled to return to the countryside, they have sent their eldest son to live with an aunt and uncle in Lima while attending secondary school, and they closely monitor the progress of their other four children in elementary school, who walk into Paucará every day rather than attending the smaller, more rural, and "inferior" school closer to their home in Chacapampa.

Manuel also spends a considerable amount of time working in Lima. When he is at home he tends the family's fields, works as a tricycle porter in Paucará, and sells cds and dvd music videos at a table at the weekly feria. Rosa also has a busy food stall in the Sunday market, where she sells a complete menu for S/. 1.50 with sopa, segundo, and café. During the week she often helps her mother Verónica pasture her sheep, sometimes bringing her four pigs and youngest pre-kindergarten daughter along.

Rosa and Manuel struck me as people who perceive their livelihoods as humble and who very much want to progresar (make progress; see Paerregaard 1997: 19). Rosa 
was somewhat ashamed that she cannot read or write; she only completed a few years of elementary school and after her father died was not able to consider more education. Manuel apologized that he spoke neither Spanish nor Quechua "very well": his accent and incomplete Spanish marks him as a serrano (a derogatory term for inhabitants of the sierra or highlands), and according to him the Quechua of the region is mixed with Spanish, unlike the "proper" or "real" Quechua of Cuzco.

Although they perhaps remain poor campesinos in their own eyes despite their efforts, Rosa and Manuel want their children to improve their lives with better education and competency in the mestizo culture of the city. They are proud that their children do not have to work and can instead focus on their studies, and they have high hopes for their eldest son, who they expect to enter a trade or some other working-class profession upon recently completing his secondary schooling. As Paerregaard indicates, through urban migration, monetary employment, and education, Rosa and Manuel hope for their children "to become true members of Peruvian society" (1997: 19). Yet at the same time, they remain profoundly (and corporally) connected to the highlands.

"I didn't always live here," Rosa tells me. "I lived in Lima for seven years with Manuel. I had three children then. I had another bebita who died when she was three months old. She died from chocando when I brought her to visit Paucará... I worked selling food on the street, you know, like Teofilia does at the feria here. We were doing well enough, but Manuel fell ill. We took him to the hospital and the doctors said he was malnourished. They gave him lots of injections and pills - I worked hard to buy all the medicines, selling food on the street with a baby at each breast - but still Manuel was sick. He had no 
strength; he couldn't even get out of bed. I thought he would die, so we returned here [to Chacapampa]. We consulted a curandero and he said that it was the diablo chacho making him sick... When Manuel was younger, he had a bad father, a drunk, and he spent many nights sleeping on hillsides with his mother. Who knows how many years he had that diablo inside him. We fed the diablo and Manuel got better. Now you can see him, he is fine... I believe in the satanas and curanderos. Doctors don't believe in them, so they can't know. That's why they couldn't cure him."

Although my informants generally reinforced the common ethnographic interpretation of Andeans as successfully integrating new modes of social organization and livelihood strategies into their customary practices and beliefs - for example, the people I met were for the most part actively engaged in creating new (and urban) social networks and livelihoods so as to ensure well-being, prosperity, and advancement for themselves and their families - it seems that Paucareños regard these movements and exchanges (albeit desired) with some ambivalence. Rosa and Manuel wanted to leave the highlands because they see the city as offering the assets and opportunities that they want and need to succeed and progress. Yet they were compelled to return to the countryside to feed the diablo that was making Manuel sick. The force of the "great circulatory system" (Seligmann 2004: 173) is apparently not something that can be easily abandoned or broken. Even if it was not something they consciously desired, the practical consequence of their decision to cease farming and move to the city was that their ritual obligations to feed the hungry Places would be neglected. 
Urban migrants do not readily forget their communities of origin. They continue to return to them, such as for annual fiestas. They continue to invest in them, for example through remittances sent to relatives who remain there. They continue to maintain a claim to them, such as families who keep their lands even though they may not cultivate them. And these same Places continue to have a hold on migrants in turn: the emplaced powers associated with their lands and their communities of origin continue to demand to be fed. Some migrants, such as don Pedro, continue to feed the mountain spirits even though they now live in the city; others such as Veronica's second daughter remain sick because they have not fed the appropriate diablo.

While some sources point to capricious mountain spirits who can cause sickness and misfortune as a result of ritual neglect (for example Allen 2002[1988]; Gose 1994), others emphasize similarly emplaced spirits (that are associated with the highlands, although they are not embodied in specific landforms) as the cause of sickness (see Crandon-Malamud 1991; Spedding 2005). These include diablos, sirenas, and pishtakus. They all have their own historical genealogies and unique symbolic associations; the relevant point here is that they are hungry spirits who must also be fed with ritual plates of alcohol, coca, incense, minerals, and other special foods. In fact, it sometimes seemed in Paucará that these disembodied, de-individualized, yet emplaced spirits are more present in peoples' lives than the mountain spirits or pachamama. From what I observed, diablos are more prominent in the life narratives and daily experiences of Paucareños; their threats are of a more immediate concern than the tutelary powers that are more directly concerned with agro-pastoral fertility and success. It is these diablos that exist on the wind or in pools of water that can enter one's unsuspecting body and feed off their 
energy or souls, causing misfortune, distress, sickness, and even death. These sicknesses are themselves indications of an unbalance in the relationship people have to the sources of health and fertility, a point that will be returned to in Chapter 6 .

Crandon-Malamud's (1991) ethnomedical work in highland Bolivia suggests that people may fall victim to hungry diablos, malicious pishtakus, and a host of other emplaced powers particularly in times of socioeconomic upheaval, the transformation of existing sociopolitical hierarchies, and dramatic shifts in livelihood strategies. CrandonMalamud found that in post-revolutionary Bolivia in the 1970s, in which agricultural holdings and the balance of power had been dramatically restructured, Kachituños experienced, interpreted, and addressed sickness and misfortune in a variety of ways that aligned them with either a mestizo and modern or Aymara and traditional orientation, which strategically allowed them to gain access to "secondary resources" in their pursuit of context-particular identity and livelihood strategies. ${ }^{16}$ What is particularly striking for our present purposes are the numerous conditions (even deaths) experienced by disempowered and struggling "indios," Aymara youth who perceive their rural "backwardness" while hoping for upward mobility, and newly impoverished and demoralized vecinos of a pre-revolutionary ruling upper class and ethnic elite alike, that all may be attributed to the hunger of emplaced spirits: ${ }^{17}$ the kharisiri (a white or mestizo fat-extractor who takes this force of life and vitality from runa to oil and enrich the machinery, wealth, and power of the mestizo world), El Tio (a trickster uncle who is basically good but creates evil out of his hunger for power), achachillas (little old men

\footnotetext{
16 "Drawing on medical ideology, Kachituños employ medical dialogue and choose curative strategies primarily to negotiate the content of ethnic and religious identity in order to gain access to material and nonmaterial resources that will provide them with social mobility" (Crandon-Malamud 1991: 138).

${ }^{17}$ In addition to these supernatural causes, conditions may be diagnosable by "cosmopolitan" medicine or moral decrepitude (Crandon-Malamud 1991).
} 
who live in mountains and rivers), khan achachi (balls of fire with long tails), and anchanchus (teasers and tormenters, often appearing as a loved one) (Crandon-Malamud 1991: 120,124-128). These spirits can cause conditions ranging from mental distress and wasting sickness to crop loss and sudden death. What they share in common is a demand to be fed:

The metaphor for the operative principle behind supernatural human interaction is insatiable hunger. Just as the Bolivian elite exploit the Indian for their sustenance, so too are the supernatural dependent on human beings. They interact with humans principally to satisfy their appetite: they either protect health in exchange for food or impose disease to extract it. (Crandon-Malamud 1991: 124)

Places such as the mountain spirits, pachamama, the ancestors, and the Tio continue to address Andeans, potentially towards productive ends (see Chapter 5). Conversely, diablos and similarly emplaced powers are another way that Place continues to have a hold on people, but this time towards no productive end, or at least none of benefit to runa. Instead of having a reciprocal relationship of cohabitation with people, these spirits prey on runakuna, sucking their life-force and taking it out of circulation, for their own (individual) benefit.

In a way, these diablos seem to speak to the "exploitation" of highland peasants by rich and powerful outsiders (see Crandon-Malamud 1991; Kato 2005), or at least their continued suffering and impoverishment despite their hard work and efforts for advancement. But in another way, they speak to the increased threats emerging in the lives of runakuna as a result of their neglect to feed these Places. Paucareños are spending less time in the countryside, are leaving their lands to seek new livelihoods in cities, and are feeding social networks elsewhere. Perhaps it is the case that the lands (or 
social networks) are no longer working for them as they "should": people feed the mountain spirits, but still they do not improve or advance. Alternatively, perhaps it is the case that people want to advance in different ways today than in days gone by. Since there are limited opportunities for such advancement perceived in the highlands, people increasingly elect to move to the cities to gain access to the skills, opportunities, and social networks they need to not only obtain a livelihood, but also progress on their own terms. Nevertheless, these Places remain hungry. Perhaps they have even more hunger now that they are not being fed, and so they are retaliating with sickness by feeding on runa instead.

“When Mamaku was sick and about to die, I prayed for her," Rosa confides over a bowl of soup. I prayed for her with Lidia. I said, 'Okay, I will pray with you and if Mamaku gets well, I will believe you and I will become Evangelical.' So we prayed that night, but I didn't feel well. And the next day when I went with Mamita's [Verónica's] sheep to the pasture, they started peeing blood. It was a punishment from God. Now I will never again think of converting to Evangelicalism, I am only Catholic." For her part, Lidia is adamant that Evangelical Protestantism is the one "true religion," for she has told me that she was sick for ten years before she converted. Nothing worked to cure her then, but now she needs only fe, faith in God - "not pills or doctors [or curanderos], nada!"

Aside from migration and (dare I say) "modernization," there is another movement away from the feeding of hungry spirits in the Andes: conversion to Evangelical Protestantism. This movement is, as Lazar (2008) notes, one that is 
purportedly absolutist, professing to be the "one true religion" that denounces customary Andean practices (ritual offerings, drinking, dancing) as immoral and denies the very existence of emplaced powers such as the mountain spirits (156-171). It is, on the surface, a shift away from the "syncretism" typical of the Andes that accommodates multiple orientations and strategies for livelihood, well-being, and advancement (for example, in the simultaneous holding of Catholic and indigenous religious beliefs). It would appear that Evangelicalism rejects "relative and shifting categories" in favour of absolutist essentialisms (Lazar 2008: 167-168). However, while Evangelical Protestantism does indeed demand a radical repudiation of the feeding of hungry spirits (see Lazar 2008: 159, 161), and its most overt differentiation to Catholicism in the Andes is the abstention from drinking alcohol, "[p]eople often only partially adhere to Evangelicalism" (Lazar 2008: 169). ${ }^{18}$ In practice, "[p]eople slip in and out of Evangelicalism" (Lazar 2008: 160; see also Crandon-Malamud 1991; Paerregaard 1997; Radcliffe 1990; Seligmann 2004). Lazar in fact suggests that this is central to Evangelicalism: a cycle of sin and begging for forgiveness precipitated by the impossibility of living up to the strict moral and behavioral standards demanded (Lazar 2008: 168-169).

For some, like Lidia, adhering to Evangelical Protestantism is how to live a moral and healthy life while improving one's household. One denounces the power and efficacy of the mountain spirits and other emplaced powers, along with rituals and ritual practices

\footnotetext{
18 "This is somewhat peculiar, because it would seem to be logically inconsistent to have an absolutist and essentialist approach to identity (such as a concern for what might be the true religion), and at the same time to hold two or more of those identities concurrently or sequentially. Hybridity would seem to be possible only if the identities that exist together are porous, undecided, and shifting. But in El Alto [La Paz, Bolivia], hybridity can consist of different fundamentalisms or absolutisms. People do not and usually cannot make the choice between the two religious domains in a once-and-for-all way" (Lazar 2008: 169170).
} 
directed towards them, namely drinking alcohol. Evangelicals see themselves as not "wasting" money and resources on costly fiestas or rituals. Indeed, the prohibition on drinking is often a primary motivation for conversion, as evidenced by the many women who persuade their husbands to follow them in becoming Evangelical so as to no longer spend scarce money on alcohol or beat them while drunk (see Lazar 2008: 159, 163). Rather, one is to place all of one's "faith" in God through a personal relationship with the divine (see Lazar 2008: 163). For believers, this faith (along with their own moral uprightness and hard work) is sufficient to ensure health and prosperity.

But for others, like Rosa, these advantages are not enough to overcome the persuasive power of the hunger of emplaced spirits. She was willing to convert to Evangelicalism so as to guarantee Mamaku's recovery from the brink of death, probably bolstered by Lidia's own miraculous experience of health after her conversion: apparently she was sick for ten years, throwing up every day, before she became Evangelical. But Rosa found that instead of bringing health through faith, her abandonment of the hungry Places would only bring misfortune and death.

We are making our way down from Calvario, a mountain that we visited with a chapel overlooking Paucará. As we pass by some rocky outcrops, we spot a group of people in a hidden clearing below. "It's a culto!" exclaims Susana. "Look, there is Lidia and Jeremiah." I peer over the ledge and spot Pedro's youngest sister and her husband. They are with a group of Evangelicals, kneeling and praying, facing the rock wall of the outcrop and the ground. "Que feo!" she says in regards to their wailing prayers. "Let's take a picture." Some time later, Rosa comments that Lidia told her she has seen and 
talked with God. "But who can see God?" She thinks instead it must have been a diablo that Lidia was really talking with. "God is in the sky," says Yhosef. "But for Evangelicals, their god is in the ground. That's why they pray to the ground instead of looking up at the sky, where the true God is."

Converting to Evangelical Protestantism is not simply a personal choice or a matter of taking up a new strategy of well-being, however. It is a major change in one's social relations: Evangelicals do not drink alcohol, do not participate in rituals directed towards mountain spirits, and (ideally) do not sponsor or attend public fiestas such as that of Mama Cocharcas, the patron saint of Paucará. This can mean a dramatic disengagement from existing social networks of reciprocity and obligation and the disillusion of friend- and kinship ties.

In Mamaku's family, Lidia's conversion to Protestantism sits in a rift of familial solidarity and trust, which admittedly may not have been the result of her abandonment of Catholicism, but may be indicative of longer-standing, systemic tensions in the family of which I am not fully aware. Lidia, her husband Jeremiah, and their three school-aged children live outside of Paucará, where they raise potatoes and other crops and tend their sheep. Jeremiah also travels to Lima for periods of migratory labour, and their two older children work in a restaurant in Paucará on the weekends. Mamaku "lives" with Lidia and her family: in their walled yard, she has her own house and kitchen, where she prepares all her own meals with her own stores of food. Mamaku spends her days pasturing her and Lidia's sheep, and she often visits Verónica in her kitchen in the morning and the evenings, where they sometimes share meals. 
Although Verónica and Lidia live a stone's throw away from each other, and often pass each other when tending their fields or animals, they rarely talk, and they never visit each other. From Verónica's perspective, Lidia only cares about her own family and making money; she rarely offers assistance or generousity to her impoverished, widowed elder sister. On a visit, Yhosef once covertly asked Lidia's son to lend him his father's tools to do some repairs at Verónica's house; Lidia would not have permitted this lending, perhaps because it would have drawn Verónica (and Yhosef) into a closer relationship that she does not want to acknowledge. The extended family is also suspicious of the allegedly money-concerned and selfish Lidia, suggesting that she was in some way responsible when Mamaku's cuyes (guinea pigs) died, her house became dilapidated, and her hidden stash of money "disappeared" during her hospitalization and extended stay in Lima after falling deathly ill during a rare Christmas visit. ${ }^{19}$

For her part, Lidia thinks that she has found the "one true religion" and would like to convince her (adamantly opposed) extended family to convert to Evangelical Protestantism like she has. Until then, she does not seem to have much to say to them, partly because of her brusque and proud character, and perhaps partly because she has forged new relationships and social alliances with Evangelicals who likewise abstain from prohibited practices such as drinking alcohol. (Jeremiah's abstention did not go

\footnotetext{
${ }^{19}$ Mamaku traveled with Verónica to Lima for the wedding of Verónica's son just before Christmas. After the wedding party, which included drinking outside until the early hours of the morning, Mamaku fell ill and was taken by the family to a hospital. Some said that she became sick because she drank cold beer and soda; others said it was because she was frightened by a bull on the road before leaving Paucará. In any case, Mamaku almost died in the hospital from a condition or complications that I still do not know of. A doctor who attended her allegedly said that she had "lived enough" already, and the family began making preparations for the funeral with great sadness. Verónica said she would never return to Paucará because she could not bear to live totally alone. Mamaku did recover, however (she said she wanted to return to Paucará to care for her sheep), and spent another month in the home of don Pedro recuperating.
} 
unnoticed by other men at events such as weddings, and Susana fondly looked at photographs of when he and Lidia still participated in the herranza).

Perhaps some Evangelicals are truly successful in taking on new beliefs and practices; similarly, perhaps many urban migrants do in fact forget or abandon the emplaced powers of their natal communities. But for his part, despite having lived in Lima permanently for the past ten years, Pedro Bautista has not forgotten the mountain spirits. In addition to performing ritual cures for local clients, don Pedro often does recomendaciones and consultations with ritual mesas (tables) in his home in Lima for himself and family members. He once even brought wine and coca to the top of a hill overlooking his neighbourhood of Bayovar, San Juan de Lurigancho, to seek a recomendación on my behalf. Don Pedro and his family may go to a church to pray to God, consult tarot cards about a present problem or prospects for the future, bathe with herbs such as ruda to increase their luck, or bring a recomendación to a mountain spirit either in Lima or back in Paucará.

Perhaps for them it is not problematic to combine these beliefs and practices, because it is necessary to address various divine powers in their distinct ways. As don Pedro says, there are three gods: "primero díos, segundo dios, tercero díos." The first god, the "principle one," "is in the sky." This is the Christian God the Father "who created the sky, the earth, the world." The second god is "that in which we live": the earth, "Pariamama." The third god is "los Cerros, los poderosos," the powerful mountain spirits. These three gods correspond to the three worlds of being and existence: hanan pacha, kay pacha, and uku pacha. I think that for the Bautistas, it is obvious that the three gods all exist together, for any Place simultaneously exists in the world above, the world 
of the earth, and the world below. These gods are ultimately all of the same kind (see Lazar 2008: 154).

While in pre-colonial times the simultaneous existence of these three worlds (hanan pacha, kay pacha, uku pacha) did not have "celestial" or "demonic" designations, some five hundred years of Christian influence and Catholic hegemony now have them associated with the celestial realm of God, the earthly realm of humans, and the interior realm of the devil. Thus the "benevolent" mountain spirits are in a general way associated with hanaq (the part above), the heavenly realm of the Christian God the Father, and "malicious" gentiles and diablos are associated with $u k u$ (the part inside), the interior of the mountains and the demonic underworld (see Gose in press: 387-388, 398, 402-404).

As this indicates, the socialization and ritualization (as well as embodied experience) of Place plays an important role in how Andean people are at once emplaced themselves and engage in movements and exchanges held in specific places. The market is also a site for such movements and exchanges in the Andes, and it is to this that we now turn our attention.

Tía Verónica takes me to the Vaso de Leche meeting in Paucará, where poor women receive their monthly allotment of government-issued kilogram of mixed cereal or “quaker" (oatmeal, quinua, kiwicha, soya, and barley enriched with vitamins and minerals) and eight cans of evaporated milk. In his Spanish presentation for the sixty or so women, the visiting nutritionist stresses the importance of serving the fortified cereal to their children every day, and of eating nutritious local foods such as potatoes, chuño, maize, barley, wheat, oca, olluco, and mashua, rather than selling the government-issued 
cereal or canned milk to buy bread, noodles, rice, sugar, or candies. Afterwards, he tells me that Huancavelica has the highest rate of malnutrition in the country. He is genuinely interested in improving the lives of people, and especially in the growth and development of children, but he is also frustrated by the "backwardness" of the rural "Indians." He shakes his head, saying "these people just don't know how to live."

Paucará is indeed situated in a poor highland department, where children are chronically undernourished and families do what they can to survive. The ethnocentricism of the nutritionist, however, obscures the potential richness of the area (not to mention the perseverance and resourcefulness of its inhabitants), with its varied products and bustling markets.

Huancavelica is a high-altitude department generally oriented towards the pasturing of sheep, llamas, alpaca, and cattle, and the raising of crops such as potatoes, barley, oats, wheat, and corn. In terms of domestic consumption, by far the most important of these crops is potatoes, of which there is a seemingly infinite variety suited to particular growing conditions (e.g. high-altitude, cold, dry, poor soil) and culinary uses (e.g. to be boiled or roasted; for soups or sides; for immediate consumption or freezedried as $c h u \tilde{n} o$ ). Huancavelica is famous for its particularly tasty potatoes, and they are featured in almost every meal, whether it be the morning soup, the midday fiambre, or a special dish bought in the market.

Most of Huancavelica's agro-pastoral products are bound for household consumption and local markets; a small sector of large-scale producers exports products to neighbouring departments (see DIA 2006). Huancavelica also obviously imports 
consumables and other goods from other departments, most notably processed foods such as rice and noodles. It is easy to find such exogenous or imported foods and other goods in Paucará, although the weekly market is dominated by regionally-produced staples such as potatoes, chuño, corn, barley, oats, wheat, lentils, and habas (fava beans); vegetables and fruits such as peas, squash, carrots, celery, onions, garlic, avocadoes, tomatoes, apples, mangoes, limes, oranges, and bananas; and meat and animal products such as sheep, beef, pork, chicken, eggs, cheese, charqui (sun-dried, jerky-like meat), and cuy (guinea pig, which is indigenous to the Andes and has a long tradition of ritual and culinary use) (see DIA 2006; Cabieses 1997).

It is also common to find indigenous foods such as kiwicha (a highly nutritious grain, also known as amaranth), quinua (a high-protein grain), tarhui (a high-protein lupine, also known as tarwi), olluco (a nutritious high-altitude tuber with yellow, orange, blue, or purple flesh), oca (a potato-like tuber with red or pink flesh), mashua (a nutritious indigenous tuber, also known as isañu), maca (a cold-resistant root useful as a ginseng-like energy supplement that grows at the very limits of cultivation at 4000 masl), chirimoya (a unique and refreshing fruit), lúcuma (a fruit with a unique flavour and dry consistency), despertus (quince), and tuna (the sweet and refreshing fruit of the prickly pear cactus with green or red flesh; the red colouring is a result of the harmless existence of the small cochinilla insect, cultivated as a dye for centuries) (see DIA 2006; Cabieses 1997; Escamilo Cardenas 2005).

Sundays are the feria or market day in Paucará. At six in the morning, the paved streets of Paucará's normally quiet and empty core are already filling with vendors setting up tables and early-morning travelers getting a bite to eat from women cooking 
cachanga (fried rounds of stretched dough) and toasted barley café over small gas stoves. By seven the streets are bustling with vendors and buyers who have come from neighbouring towns and provinces, often arriving in the backs of large trucks. Local store owners also open their doors and set up tables outside their shops, mostly to sell household staples, and sometimes including store-front restaurants. For example, don Pedro's distant cousin Frederico has one such restaurant with his wife outside of their store; another cousin, Gladys, sells fruit and packaged foods outside of hers.

There is also a whole area of little restaurants, covered tables selling complete menus, with criollo dishes such as fried chicken or lake trout with rice, chifa (Chinese fried rice), tallarín (noodles and sauce), or lomo saltado (stir-fried beef with French fries and rice), and more typically Andean dishes such as chicharrón con chuño (fried pork skin with boiled, freeze-dried potatoes). Here Rosa has her table, a very work-intensive undertaking as she starts preparing the foods up to two days before, sleeping overnight in the market to rise early to serve breakfast and prepare the main dishes, and taking down her table only at the very end of the market day around five in the afternoon. Her aunt Teofilia also has a table where she sells fried eggs from her own chickens with fried potatoes, rice, and a small side of salad with café. She is usually helped by her youngest daughter of twelve.

On the main street running roughly from the plaza to the bus and taxi stations are vendors selling everything from household goods, to packaged food staples (rice, oil, sugar, noodles), to agricultural fertilizers, to radios and dvds. There are two side market plazas, one for fresh foods including vegetables, fruits, coca, breads, fresh beef and sheep meat, and charqui. The other is for clothing and textiles, both factory-produced items 
such as shoes, jeans, and t-shirts transported from Lima or elsewhere, and handmade local items such as polleras (skirts), mantas (all-purpose carrying blankets), and chullos (toques). (There is also a small section of used clothing on a side street). These "market plazas" were just rows of blankets and tables on the dirt, but as I was leaving in March 2008 , the district government was beginning to construct concrete stalls for the produce vendors, which would be a considerable development of infrastructure, and which I think indicates the growing importance of Paucará's market.

Finally, on the outskirts of Paucará is the livestock area, situated in and around the bull ring used for the annual Corrida de Toros that is overlooked by the chapel on top of Cerro Calvario. Here mainly pigs, sheep, cattle, horses, and donkeys are sold, although on one occasion I saw llamas as well. Men especially can often be seen milling around here; there seemed to be more visiting going on than buying and selling. (It is in this direction, alongside Cerro Calvario, that one takes the road leading away from Paucará and towards the houses of Verónica, Lidia, Mamaku, and Teofilia).

On market days, the main streets are packed not just with vendors and buyers, but with people sharing gossip and catching up on news, those getting a weekly taste of "urban" life, children having treats such as frozen yogurt, and youth showing off their new wares (a new hat or portable radio, for example). The two phone booths have people lined up in them all day, waiting for a weekly call from a relative in a city, and the three internet cafes are full of young people messaging, listening to music, and playing computer games.

I recall one Sunday when I walked to the market with Mamaku. She went not really to buy anything (although I had promised to do so), but just to look around and 
visit her daughter Teofilia. As she walked up the busy streets, jostled by people walking by in a greater hurry, I wondered at the hundreds of markets that she must have visited and all the changes she must have seen in the market over her lifetime. Most new things did not interest her, such as household goods, clothing, the internet, and the phone. She took me to the food market, where I bought her a little of this, a little of that: fresh meat, bread, coca (of which she was very discerning, choosing leaves from a particular known seller), maybe some sugar (which she allegedly stockpiles in the recesses of her kitchen). I offered to take her to a tableside restaurant for lunch, but what she really wanted was some fried chicken and bread sold from a basket in the street. ("Not this piece, that one, that one!" she croaked to the boy).

On an earlier Sunday, Susana picked out a tapa (shawl) for me. Women such as Tía Verónica wear these draped over their shoulders, clasped together with a large safety pin. I will never forget the way Mamaku wears hers, with the edge turned over to form a collar. (She also has a certain way of turning up the brim of her hat, in which she stores short hard grasses to pick out the coca in between her teeth). "Modern" tapas are made in a velvety material with garish leopard-like prints; more rustic but still popular ones are colourfully woven with the year's date on them. "Un recuerdo. To put over your television at home," Susana said. She also had fun picking out a hat for me. Women of all ages wear black, brown, or pink felt hats. The flat-topped ones are more mature, but as I later learned, the round-topped pink hats in Paucará are for girls. "There! You're a chola now!”

The market is the place where many elements of Andean society come together in contrast and complementarity. Particularly striking are the intergenerational contrasts that 
intersect with rurality and urbanization. ${ }^{20}$ The streets on market day are filled with colours, textures, sounds, and smells that are imbued with the fluid movements and exchanges of Andean peoples' lives: youth who mix jeans and baseball caps and the colourful woven socks and belts typical of Huancavelica; women who seek out shiny golden earrings that recall urban cholas to complement their embroidered blouses and woolen polleras; a television playing music videos of a group playing huaynos likely based in Lima but referencing their home regions; older women and men who sit watching the crowds and chewing coca; restaurants featuring criollo dishes typical of any Peruvian city alongside regional specialties such as cuy; rows of fresh fruit, such as juicy mangoes stacked in piles of five that come from lower, warmer regions; trucks and taxis that are loaded down with goods and passengers bound for smaller communities or larger centres.

By two in the afternoon, the market is starting to slow down. People start leaving for their home towns, some departing early to make a journey of two hours or more on foot. They will leave on dirt roads branching out from Paucará, passing by fields and houses peppering the countryside, perhaps winding their way down hillside pathways or beside streams before reaching their own homes, probably much like the ones I stayed in outside of Paucará constructed of dirt bricks, with open doorways and tile or thatch roofs.

The popularity and robustness of Paucará's weekly market indicate that the cash economy is important in the area. I suspect that access to money has increased in recent

\footnotetext{
${ }^{20}$ Paerregaard suggests that rather than institutional changes (such as the transformation of moiety and political institutions), it is non-institutional changes that represent "a serious challenge" to community identity, "such as the increasing economic differentiation of Tapeño migrants and the cultural and linguistic gap between elder non-migrant villagers and young, second generation migrants" (1997: 23). Skar provides a somewhat more sophisticated analysis, emphasizing the spatial and temporal transformations that migrants experience, along with the objectification of place and self that they undergo (1994: 39-40, 200201).
} 
years, particularly since the retreat of Sendero Luminoso and the rise in urban migration from 1990-1995 (see Dirección Técnica 2001: 32), although it is possible that the cash economy can retract as well as expand (see Paerregaard 1997: 97-98, 106). Certainly there are some foods and consumer goods and services that are available only through monetary exchange: exogenous and processed foods such as sugar, cooking oil, noodles, rice, and even locally produced bread; basic household supplies such as soap and radio and lantern batteries; school supplies such as uniforms, black shoes, notebooks, and pens; transportation costs such as bus fare to Lima or another work site; and consumer goods that are on the new frontier of local consumer desire, such as televisions, dvd players, and cds; clothes from the city; and soccer balls, internet access, or other forms of entertainment. Moreover, even if "traditional" structures such as fiesta sponsorship are not becoming more "monetized," access to thousands of dollars is necessary to host a major festival with the necessary grandeur (see for example Paerregaard 1997: 216-217; see also Gelles 2000 on the monetization of community irrigation systems in Arequipa).

For example, the Fiesta de Mama Cocharcas (the patron saint of Paucará) has two main sponsors in competition with one another to host the best party. ${ }^{21}$ One of the mayordomos represents Mama Cocharcas and the other represents Reina Chica. Sponsorship includes the public provision of two nights of dancing and music from a live band with fireworks in the plaza; a midnight meal for family, friends, and acquaintances; a parade with an adorned statue through the streets of Paucará; and a full day of bull fighting with another parade.

\footnotetext{
${ }^{21}$ The fiesta also has a third minor sponsor, the colegio or secondary school that is named after Mama Cocharcas. The participation of the colegio is limited to a show of traditional dances performed by students, a statue of Mama Cocharcas carried in the parade, and a fireworks tower during the nighttime dances.
} 
When I attended the Fiesta de Mama Cocharcas in 2007, the sponsor for Mama Cocharcas hired a "folkloric" huayno-type band with horns, harps, and fiddles. The band played in front of the church with people dancing together in large circles. The mayordomo and his wife handed out glasses of chicha, ron caliente (rum diluted in hot water and sweetened with honey), and beer (more of which was for sale at numerous tables in the centre of the plaza). At the opposite end of the plaza was a lit stage with a chicha band (popular urban working-class music) with electric guitars, drums, harp, and a female singer for the host of Reina Chica. This band attracted considerably more young people than that for Mama Cocharcas, who milled around or danced in pairs or small circles while drinking purchased beer and other beverages. Informants told me that the mayordomo for Reina Chica was a rich local businessman who had moved away and married a Swiss woman, which suggested how he was able to hire such an expensive band. The mayordomo for Mama Cocharcas was still living in Paucará, but evidently had to have access to large sums of money as well to pay for the band, the food and alcohol, and the bull fights. I should note that although cash is obviously essential for fiesta sponsorship, it is not the determining factor in sponsorship success, for even though the host for Reina Chica had enough money and ambition to set up a stage and hire a chicha band, the revelry was higher, the bulls more bravo, and the success overall greater for the more "traditional" festivities of Mama Cocharcas.

As this indicates, the social and exchange economies of Paucará are not by any means totally monetized. For example, giving gifts of food and lodging are not just important and appreciated forms of generosity, but also significant social claims and statements (see Chapter 4). In terms of direct barter and exchange, the most obvious 
instance is the annual trueque or exchange held in the provincial capital of Acobamba every September $12-14$. People from neighbouring communities (including Paucará) bring their agricultural products such as habas and potatoes to trade for chirimoya, avocado, lúcuma, despertus, sugar cane, and various other fruits and agricultural products. I accompanied Teofilia to the trueque in 2007. She brought two small bags (half arrobas) ${ }^{22}$ of dried habas from the previous year's crop to trade for fresh chirimoya. She visited six or seven different vendors, exchanging a small portion with each for the fruit at an individually negotiated barter rate. We met Verónica there, who was doing the same. Everyone ate their fill of fresh fruit that day; bags and baskets were brought home to save and share with other family members for a special treat. ${ }^{23}$

Presumably barter plays an important role in the household economy in Paucará as it does in other Andean areas (see for example Paerregaard 1997: 98-100; Harris 1989; Skar 1994). However, my general impression is that money is essential even to those who do not directly participate in monetized labour, in contrast for example to the Arequipan community of Tapay, in which "[m]oney is little used" (Paerregaard 1997: 99). For example, Verónica waited for her children in Lima to send her small amounts of cash, or for the S/. 3 from her attendance at Vaso de Leche meetings so that she was able to purchase cooking oil, noodles, and small amounts of vegetables for her daily sopa. She also purchased coca, cigarettes, and trago for the curandero who came to visit her, and

\footnotetext{
${ }^{22}$ According to the Oxford Spanish Dictionary, an arroba is between 11-16 kg according to region.

${ }^{23}$ The trueque was a festive as well as market occasion, and also included a concurso de platos típicos, or competition of traditional dishes, and a horse race. As the vendors were packing up around two o'clock in the afternoon, a small procession arrived without much fanfare or notice. It consisted of a small band, a man dressed as a woman in a black mask, another man dressed as what appeared to be a hairy monster or bear, and a man carrying a small box with a statue of the god Tatawayay. They were begging for fruit from the vendors, some of whom gave a handful of fruit out of charity, and many who simply ignored them.
} 
probably paid him a small amount for his services as well. Moreover, she hired a peon to prepare her field for planting (see Chapter 5).

The most striking instance, however, was the day Verónica wanted to buy eggs from her sister Teofilia. As we were walking back from pasturing her sheep we passed by Teofilia's house. Verónica stopped and asked Teofilia's daughter if her mother had any eggs to spare, which she was planning to cook for me as a special treat. She was even willing to pay for them, which I am not sure is normal practice or not. In any case, Teofilia's daughter returned saying no, they did not have any eggs that day. Verónica grumbled as we were walking away that Teofilia surely did have eggs; she just did not want to give or sell any to her, presumably because she was saving them to serve at her food stand in the feria. Perhaps there simply were not any eggs available (although on an earlier occasion, Teofilia readily boiled eggs and potatoes for me and some young cousins after returning from an afternoon of washing clothes in the river). In any case, my question remains: Why did Verónica's sister not want to share her agropecuario products with her? As the discussion in the following chapter indicates, it may in part have been that Teofilia wanted to feed me directly herself, and not give Verónica the prestige of feeding me valuable products that she herself had produced. 
Plate 3.1

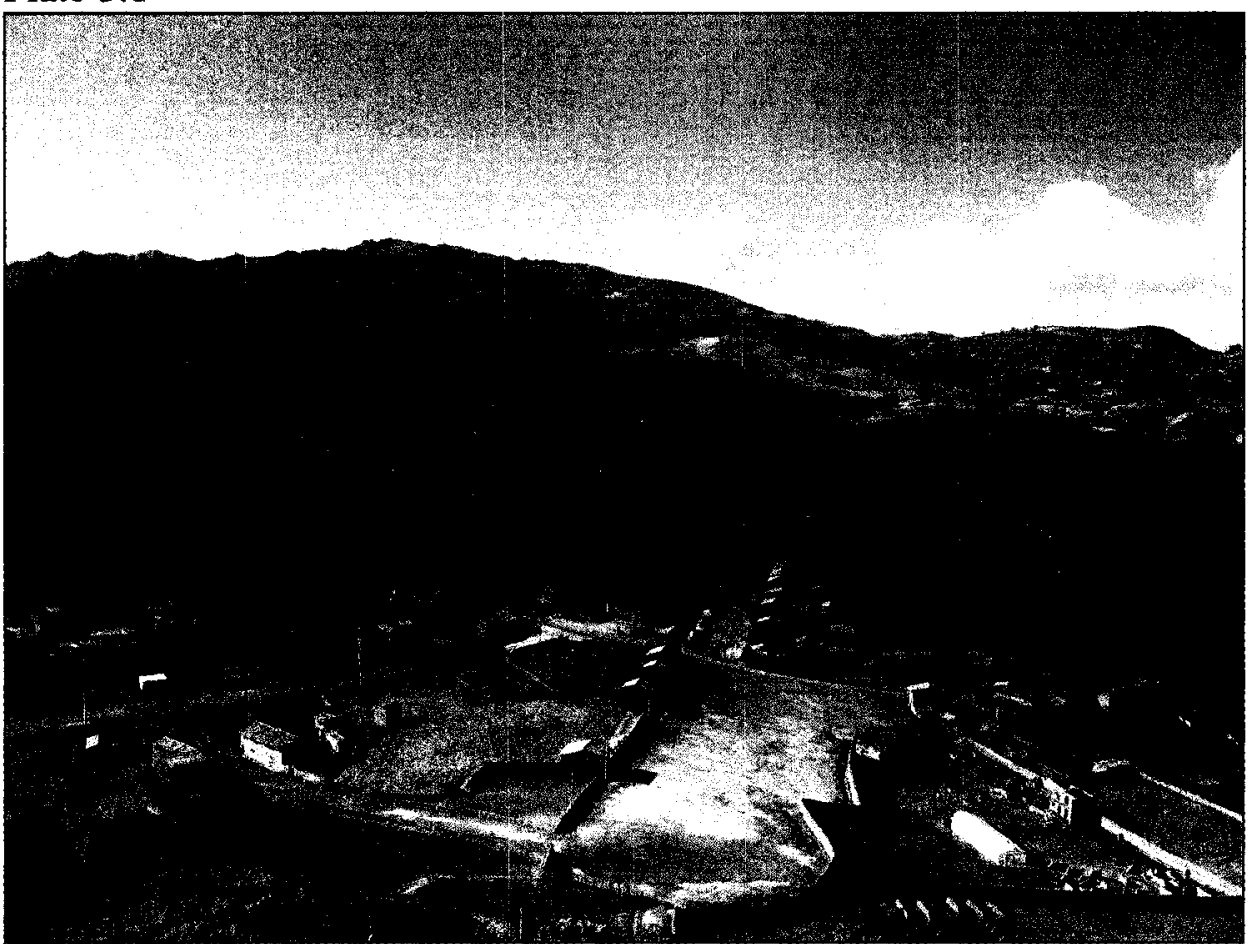

A view of Paucará from atop Calvario. September 72007.

Plate 3.2

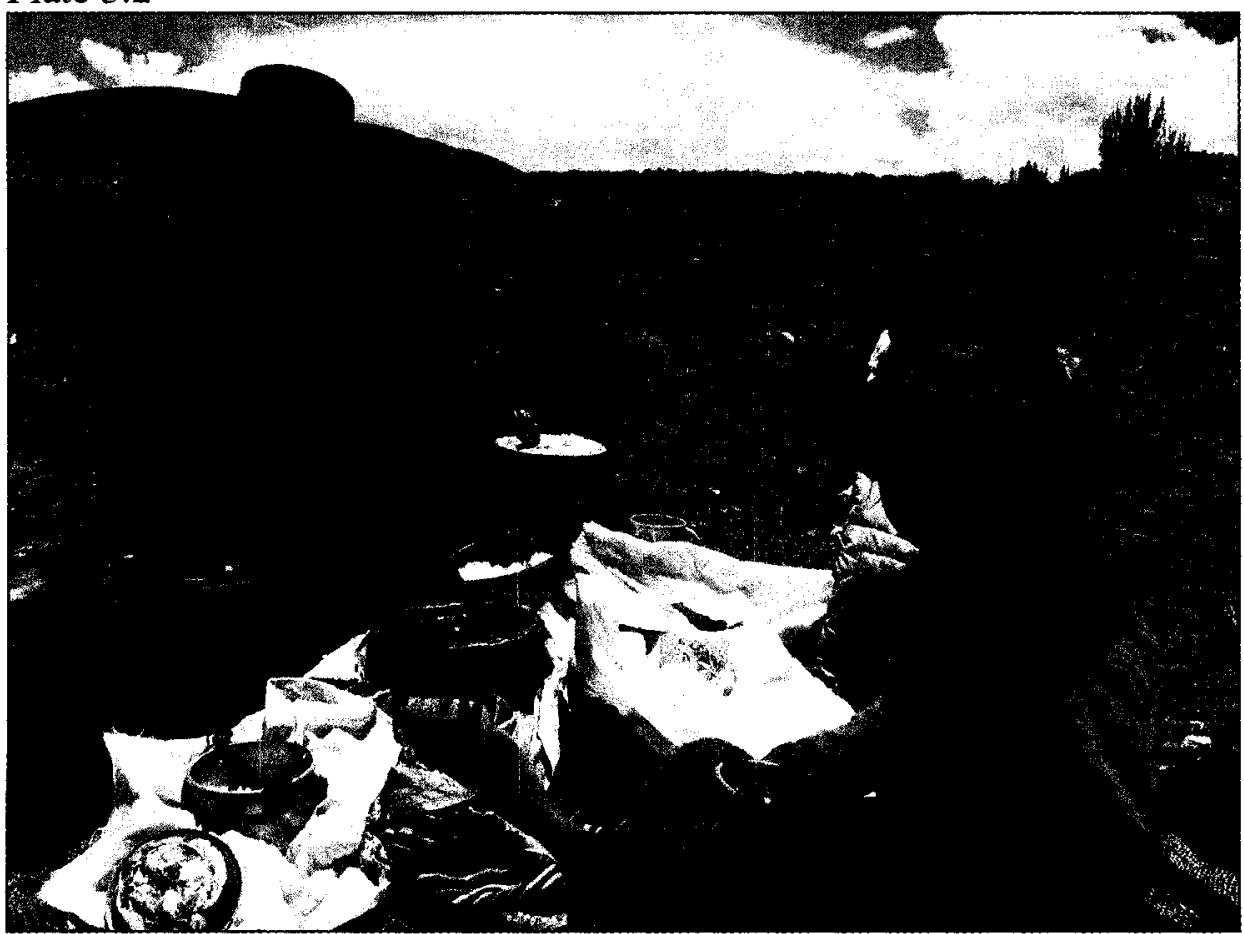

Taking a break to eat lunch while planting potatoes. Verónica's eldest daughter Rosa with her husband Manuel and their youngest daughter. Paucará, November 282007. 
Plate 3.3

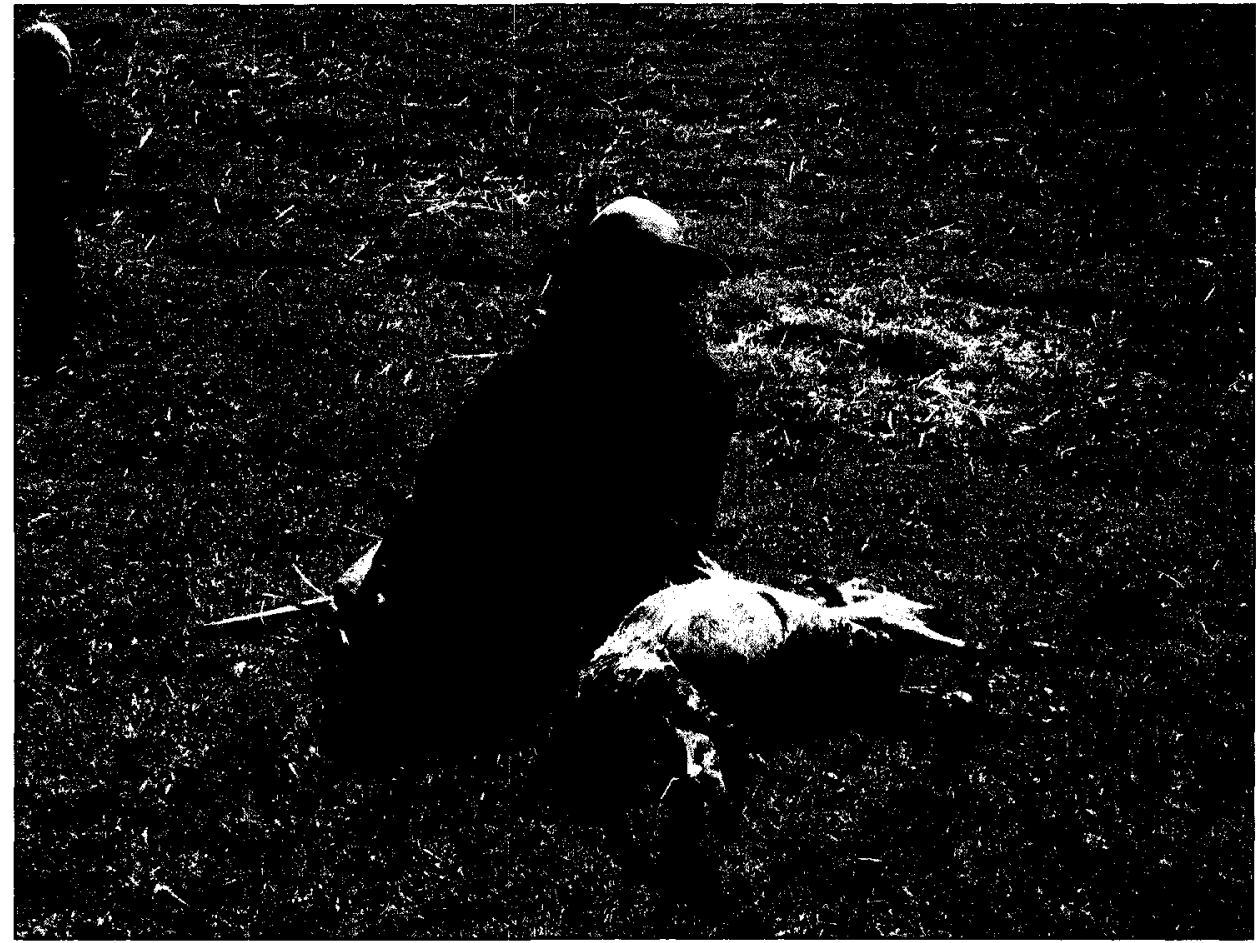

Verónica butchers a sheep that has fallen ill and died. Paucará, February 32008.

Plate 3.4

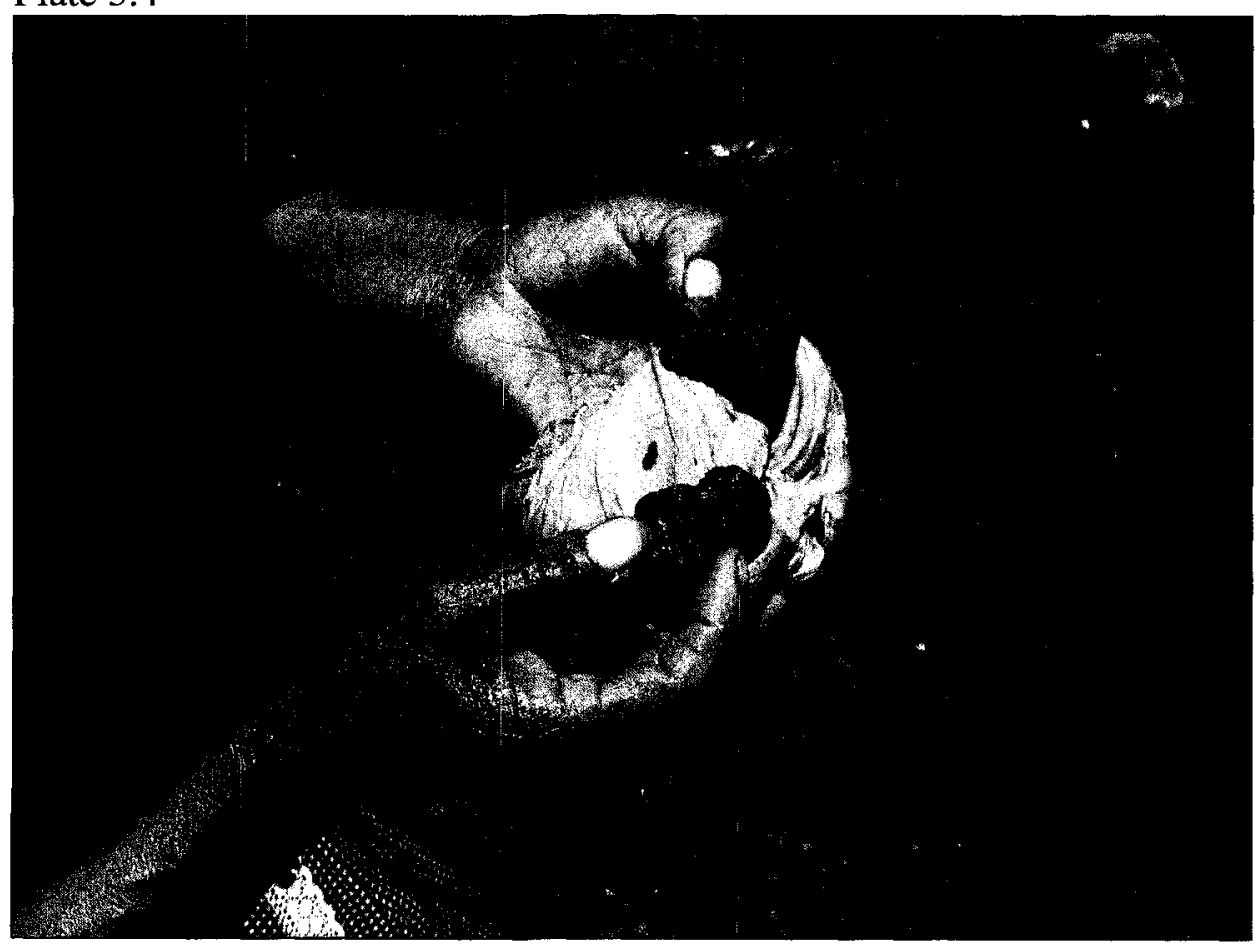

Deposits that Verónica found in the sheep's chest. Paucará, February 32008. 
Plate 3.5

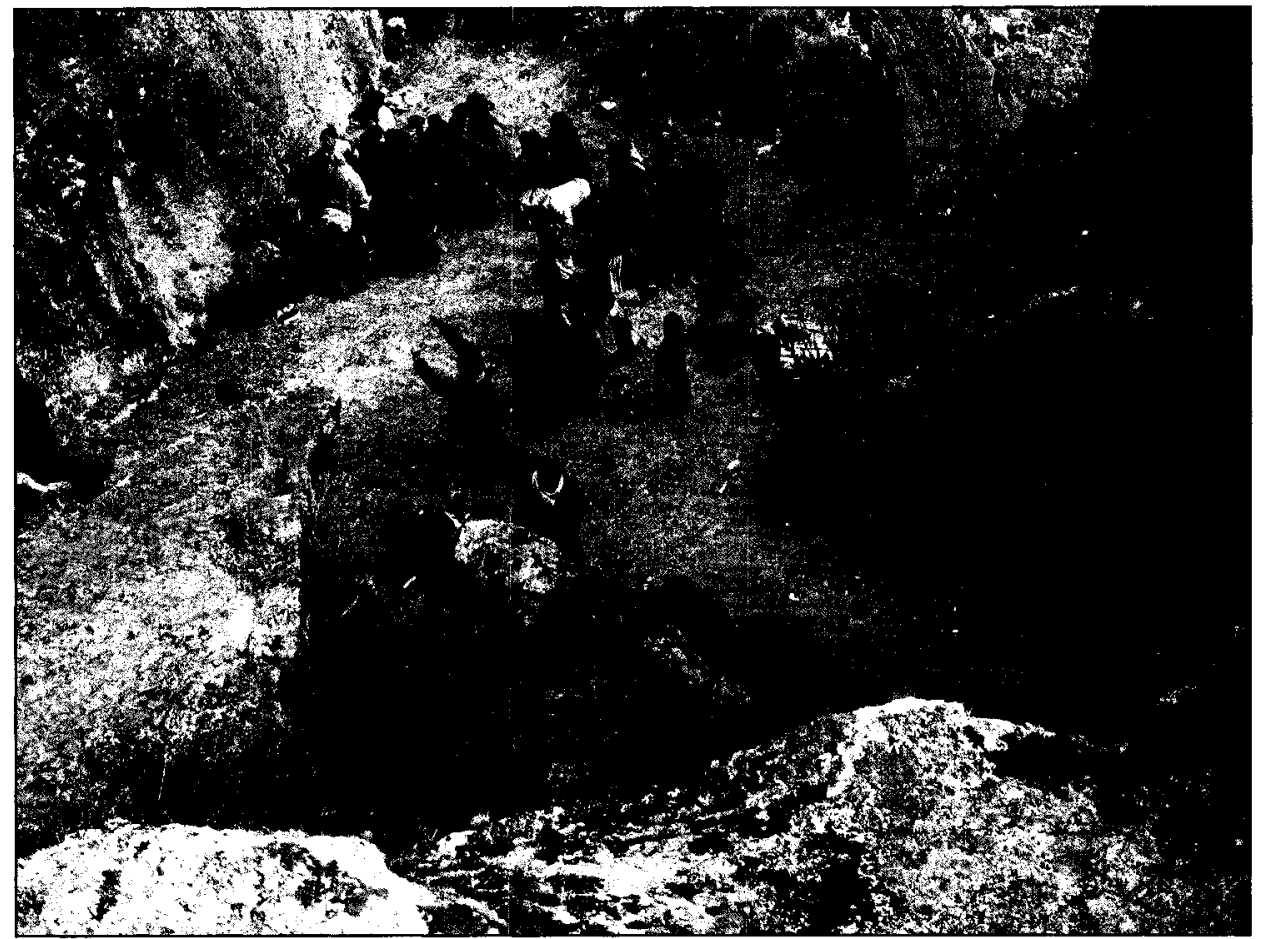

An Evangelical "culto" in the hills of Cerro Calvario. Paucará, September 72007.

Plate 3.6

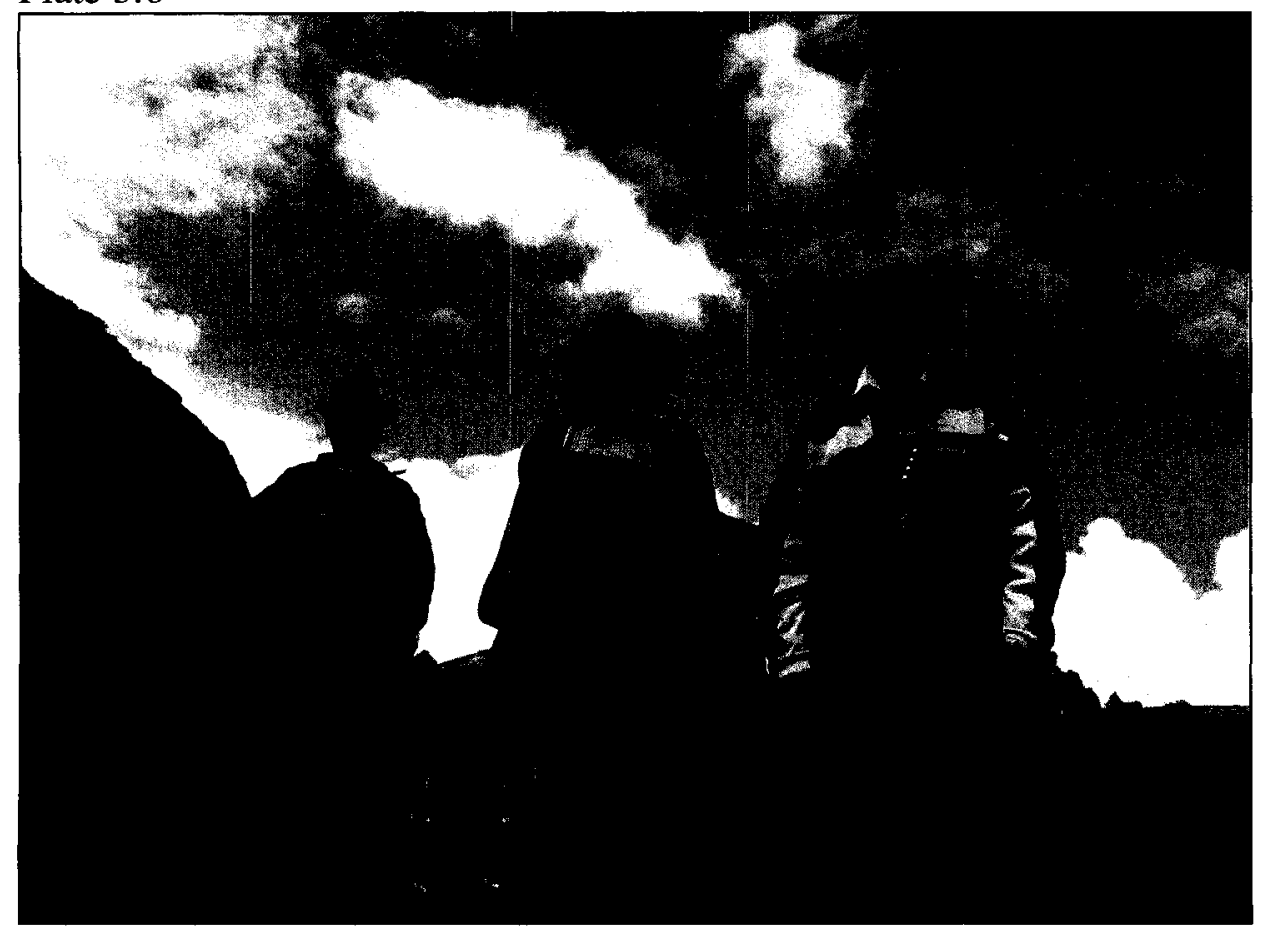

Jaime, Lidia, and Jeremiah. Pedro's youngest sister with her husband to the right; Jaime, their brother-in-law visiting from Lima, to the left. Paucará, January 302008. 
Plate 3.7

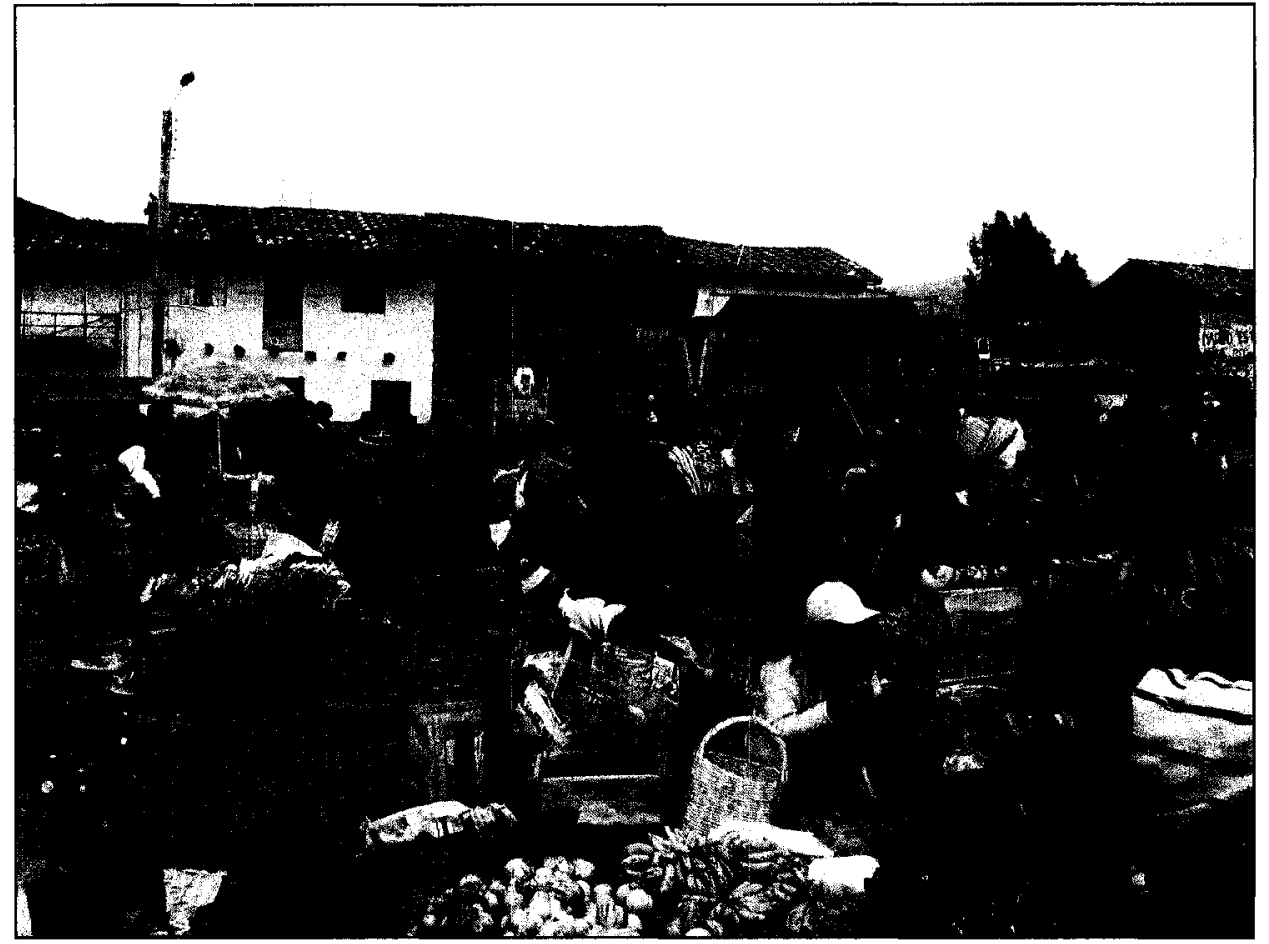

The fresh fruit and vegetable sections in the market. Paucará, September 162007.

Plate 3.8

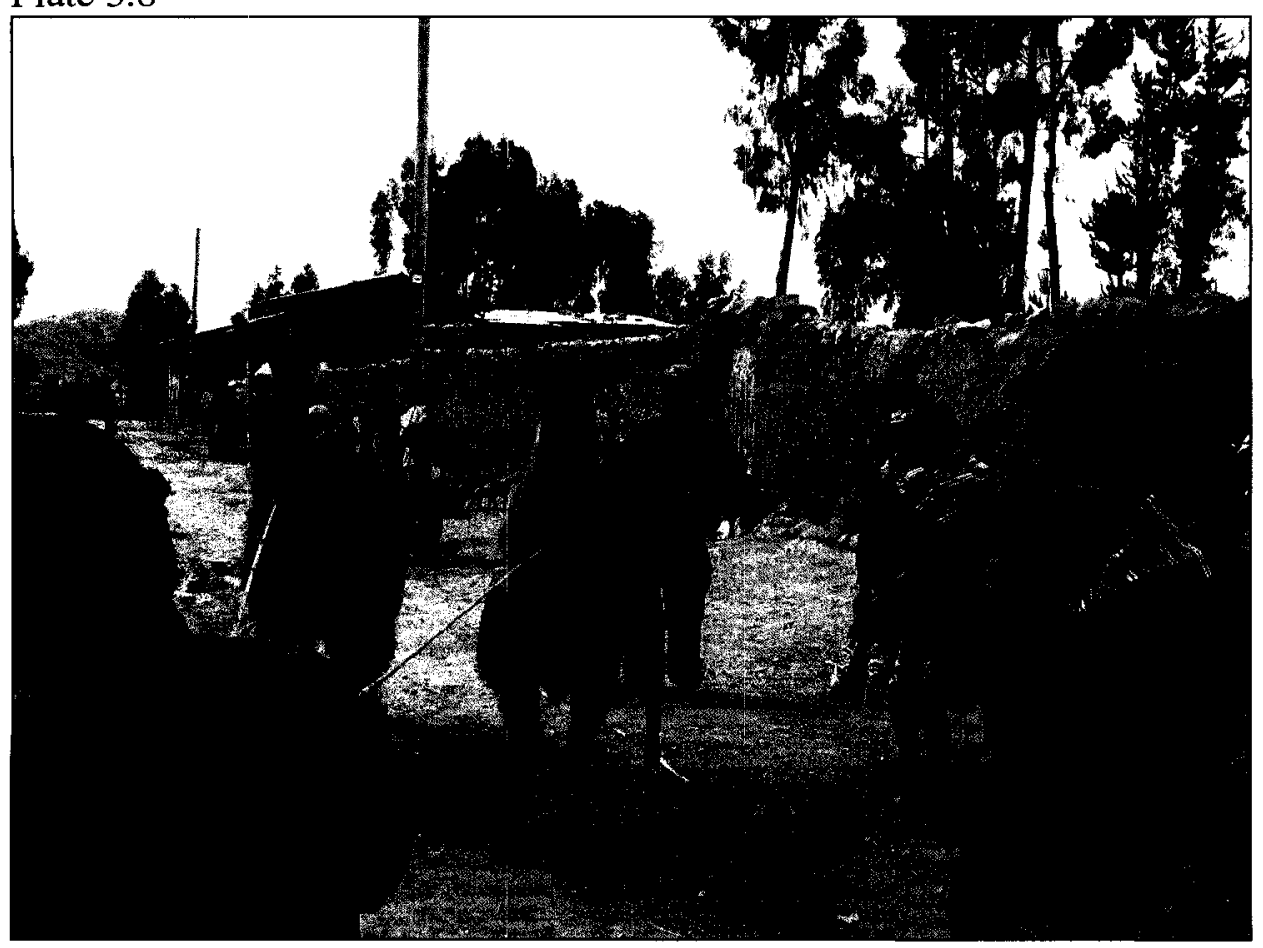

Llamas for sale at the feria. Paucará, September 162007. 
Plate 3.9

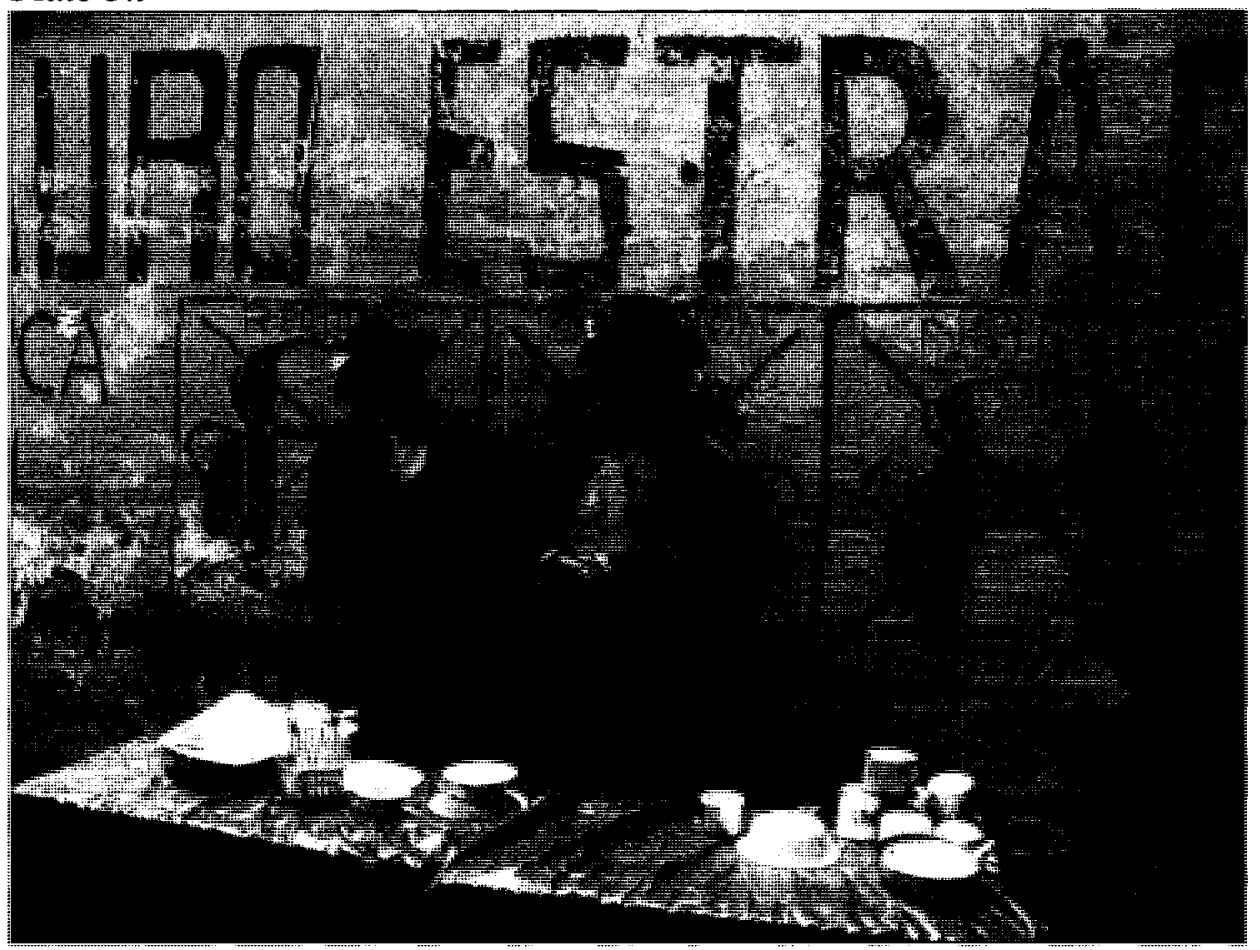

Susana and Teofilia at her food stall in the marketplace. Paucará, September 92007.

Plate 3.10

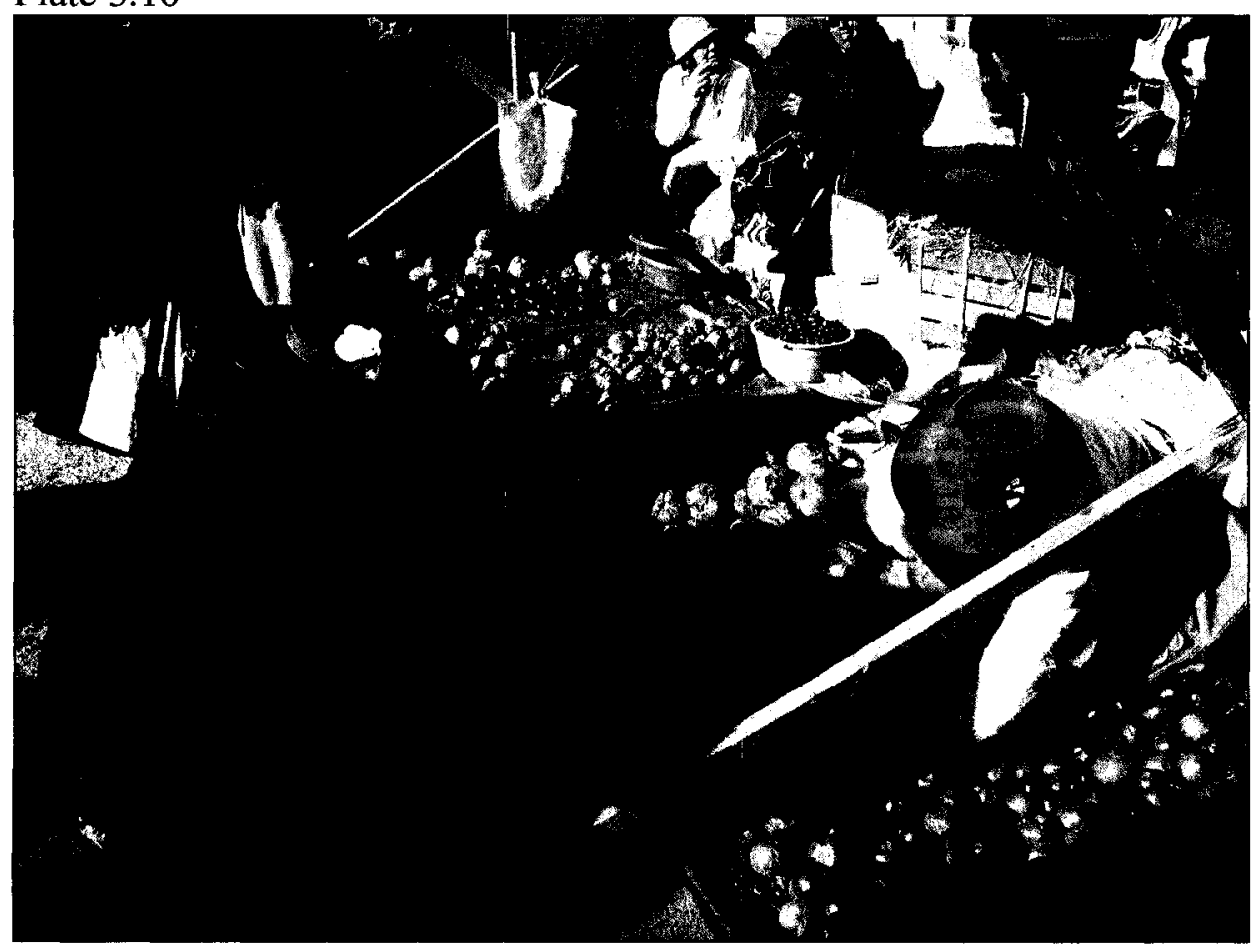

Teofilia exchanges habas for chirimoya at the trueque. Acobamba, September 142007. 


\section{Chapter 4: The Importance of Feeding}

Earlier I said that feeding is a persuasive idiom through which to make a claim on another social actor. This became obvious to me in my first month in Paucará, in which I was overwhelmed by all the plates of food and requests to visit different households to eat. These requests were made as invitations, but often they were more like demands. I am sure that I slighted more than one family by attempting to politely refuse a plate of food for my overstuffed belly or an invitation to eat at their house. It was only in time that I realized that such gifts and invitations of food condense a number of potential acts and intended meanings, including: (1) an act of generosity, such as a gift of fruit or bread on the street; (2) an act of familial solidarity and care-giving, such as the feeding of grandchildren who come to visit or encomiendas of rurally-produced foods sent to relatives in the city; (3) an attempt to place someone in a position of obligation to return in like kind, such as reciprocal drinking structures; (4) curiosity and/or motivation to obtain information about a guest or another host through a guest; (5) a claim to strategic social relations that will progress one's situation, such as the sealing of compadrazgo ties with special meals and gifts of food, or simply being able to show a connection to a relatively rich and powerful anthropologist; (6) a proposition of commensality, drawing one into family or community bodies by sharing the same food; (7) a conspicuous display of wealth, such as the feeding of guests by a mayordomo at a fiesta; (8) a claim of superiority as "feeder" in relation to "eater," as illustrated by the position of feederproprietor in relation to eater-worker in mink'a work relations; and (9) a statement of 
one's independence, agency, and power, especially for elderly and widowed women who are masters of their own kitchens but little else.

Whenever I was in Paucará, it was common to have more than one household simultaneously make competing claims on feeding me. Tía Verónica lives close enough to Lidia and Mamaku for all of them to implore me to eat in their kitchens, or bring me bowls of soup if I neglected to do so. It took some months for a pattern to be settled on, in which I ate the majority of my meals in Veronica's kitchen, but also ate in the kitchens of Lidia, Mamaku, Teofilia, or Rosa whenever possible. Even then, I am sure that I offended the other family members (in particular Lidia) by not spending more time in their kitchens.

Sleeping in someone's house does not seem to give them a complete monopoly on the feeding of a guest. Early in my fieldwork I stayed at Lidia's house one night. In the morning, I visited Lidia's kitchen, where she was preparing the toasted barley to make café. I then thought I should pop in to visit Mamaku, so I walked to the other side of the house yard to visit her kitchen. While I was there, Lidia sent her daughter with a cup of café with sugar for me. This did not faze Mamaku in the least, who proceeded to make me a café, this one with some canned evaporated milk as well (a Vaso de Leche provision), and to give me some bread (which Susana had brought her from Lima). As Mamaku started preparing the potato-based morning soup, I went back to Lidia's kitchen, intending to return shortly. There, however, I was waylaid by all the food. First there were potatoes fried with cumin and salt. This was followed by boiled and toasted habas (fava beans) and cancha de maíz (toasted corn). Finally, a substantial soup with potatoes, nabos (wild mustard greens), and morrón (roughly ground barley). Breakfast is ample as 
one generally does not eat again until supper in the late afternoon, although sometimes individuals bring boiled chuño for the midday fiambre while pasturing sheep.

Later in the afternoon, Lidia started to prepare the cena, starting with a snack of a mazamorra de trigo (a sort of pudding of boiled wheat flour sweetened with sugar; mazamorra morada, made with blue corn and often accompanied by rice pudding or sweetened condensed milk, is a popular evening snack on the streets of Lima). Verónica shortly called me for supper at her house, for which she had made me promise to return (with laments that without me, she would not bother to eat at all), but which I had found difficult to do with grace at another's house. She had already prepared sopa (on this rare occasion with rice), with the extravagant accompaniment of boiled chuño and charqui fried with green onion and salt. After completing one bowl of soup, she insisted on serving me a second bowl. I was already thinking that I would have at least one more supper to eat, so when Verónica went out to check on her sheep, I poured half of it back into the pot. Did she suspect? When she returned, she insisted on "warming up" my bowl with another ladleful, adding that I will go back to Lidia's and just eat a little mazamorra because I have already eaten enough cena at her place. She is surprisingly competitive, trying to fill me up so that other kitchens do not have the opportunity to feed me. I already know, however, that it will not stop me from being obligated to accept additional plates of food.

Indeed, when I return to Lidia's kitchen I am served a big bowl of mazamorra (which tastes remarkably like the flour paste my mother used to make as craft glue when I was a child). I see that she is making soup and some sort of fried organ meat which I would rather not eat (despite it probably being a treat or delicacy), so after my 
mazamorra I head to Mamaku's kitchen. It does not matter her one bit that I ask for a "puquitito de sopa" - she laughs and spoons the rest of the pot into my bowl (noodles, chuño, and salt in a simple hot water broth), in full knowledge that I was already stuffed at Verónica's. I then return to Lidia's, and although I am more than full, I ask for "solamente un cuchara de sopa" - now my fourth bowl. Thankfully they do not try to get me to eat more.

Market days presented additional complications, for whenever I came to town and visited Gladys or Frederico at their respective stores, they would each invite me to eat something, sometimes even trying to promise me to come to their house first for lunch so that I would not be able to eat at the other's. Gladys and Frederico were at odds with each other because Frederico and his wife had attempted to appropriate some of the space in Gladys' store in collusion with her store-front neighbour. Gladys had in fact petitioned Yhosef to intervene on her behalf, for although she has legal title to the property, Frederico is far more astute at social manipulation to get what he wants, helped by the fact that he has connections to the town leaders as he sits on the town council, and by his enterprising young sons, one of whom is a policeman and the other a law student in the city of Huancavelica. When I first arrived in Paucará, Susana and her son wanted me to stay with Gladys in town, whose home they perceived as providing greater services, comfort, and safety for me. Although I did stay with her for a week, I eventually chose to stay with Verónica outside of town. Not only were her household and extended family much more fruitful for my research questions, but living with her also allowed me to avoid being placed in the middle of Gladys and Frederico's antagonisms. Nevertheless, whenever I visited either of them at their stores, they tried their best to keep me from 
visiting the other, often making me promise to return to their houses for lunch. I commented on this once to Verónica, who indicated to me that the important thing was not so much if I returned to fulfill my promise, but that I did not decline and refuse mutual sociality altogether and simply accepted the offer.

Verónica and the rest of the family generally avoided Frederico and his store, for they saw him and his better-positioned wife's family as aggressively posturing for personal advancement at the expense of others. Indeed, he has ambitiously used his social connections and engagement in the market economy to send his sons to the city to be educated, professionalized, and mestizoized, and I have no doubt that he would try to use his connection to me to further advance his family if he had the opportunity. As a member of town council, he is well-connected to local systems of authority; moreover, his one son knows all the local policemen (many of whom were his classmates) and his other plans to run for mayor someday. Apparently he plans to build a new store and house with money that his son the policeman is saving for him. Gladys, on the other hand, has a much better store location but not the same monetary and political ambition. Her eldest daughter is studying to be a teacher but her four other children are still in elementary school; her husband spends much of his time working in their fields.

On one market day, I first visit Gladys at her store, who makes me promise to return to her house for supper. Then I pass by Frederico at his store, who I promise to visit shortly. I am looking for cold medicine, but I soon am spotted by Lidia's elder daughter, who implores me to come to the restaurant she is working at for a free desayuno, which is ponche de avena (a sweetened hot oatmeal drink), bread, and soup. Next I am offered fried eggs, potatoes, and rice by Teofilia at her food stall. Mamaku 
asks me to buy her some bread from the nearby vendors and invites me to return to the house with her, but I have to visit Frederico. When I do, he insists on giving me a plateful of aji de gallina (a criollo dish with boiled potatoes, shredded rooster meat, and a spicy yellow sauce), which his wife has prepared to sell outside of their store. A short while later, after the market is closing, I walk to Gladys' house for supper, where I am offered two heaping plates of rice and pork.

Early on in my fieldwork, I spent considerable energy trying to negotiate all these invitations to social interaction and competing claims on my presence made through food. Equally important were prestation gifts of food on my part. When Susana and Yhosef came for the Fiesta de Mama Cocharcas, they brought gifts of large sweet breads bought outside of the bus station in Lima. This bread is different from little breads made locally in Paucará, and they were much appreciated by the family, who, like Weismantel has said, indeed are "crazy" for bread (Weismantel 1991: 866). ${ }^{24}$ Susana brought a loaf for each family, as well as one-kilo bags of sugar, fruits, and bottled juice from Paucará. They told me it was very important to always arrive at their family's houses with gifts of food, because as discussed below, to do so is to act with social competency, respect, and decency. When I returned to Paucará in November, I brought the same bread from Lima, and in Paucará I filled up my bag with sugar, noodles, canned tuna, cooking oil, oatmeal, canned evaporated milk, and cookies for Verónica, Lidia, Mamaku, Teofilia, and Rosa and her children. These purchased foods were all enthusiastically received as I handed them out over the following week.

\footnotetext{
${ }^{24}$ Yhosef commented to me that when he was younger, bread was a much coveted, rare treat. It was the best thing he knew of to eat; he felt he could live off bread. Presumably now bread is not so special - or tasty - as he can have it any day he likes (see Sutton 2001: 64-65; Counihan 2004: 177-181).
} 
I also brought bread from Lima for Gladys and Frederico, which were less successful. I suppose that such foods are not gifts or treats for people who have access to such things at their own stores, but I thought something was better than nothing. More successful were the shoes that I brought for Gladys as thanks for the week that I stayed with her family. I am obviously ignorant of what is an appropriate prestation gift for mestizoized town dwellers, especially ones with whom I do not want to make a more formal connection but to whom I am indebted. However, for runa and subsistence farmers, who have limited variety in their diet and only sporadic access to purchased foods, and who know hunger well, food is the perfect gift. Bringing such gifts are not just appropriate in anticipation of the meals guests will be offered in turn, but because as Weismantel says, it is incumbent on the returning traveler to bring home something from the outside - some wanlla or treat, of which bread is the "wanlla par excellence" (1999: $144,146)$.

Weismantel describes wanlla as a gift and treat that is not part of a regular meal prepared at home, such as fruit, sweets, cooked market food, and above all, bread (1999: 144). Wanlla are foods bought in order to be given to others, whether a family member to whom one offers the pleasure of a treat while "gain[ing] a slight advantage in prestige over them," or to real and fictive kin towards whom one "expresses respect and the acknowledgement of an ongoing relationship" (Ibid.: 144-145). I did not hear the term wanlla used in Paucará, but I often observed foods being used in similar ways as described by Weismantel for highland Ecuador. Family members do indeed treat one another when possible with breads, fruits, and cooked food on market days, and recipients often save some of these gifts received "to be redistributed later," for part of 
the pleasure indeed is "the possibility of using the treat as a gift for someone else" (Ibid.: 145). I learned to give more bread or fruit than would appear to be sufficient for one person, for I knew that individuals would save some to give to other family members in turn.

In other contexts, purchased foods such as noodles or sugar are suitable as gifts that are not essential for the maintenance of the household, even as they are in practice household staples ${ }^{25}$ (see Weismantel 1999: 144-151). While breads and other foods from the city are gifts and treats brought into the household from "distant places" by a returning traveler and involve a subtle "exercise of power" beyond ostensible generosity, gifts of noodles, sugar, canned tuna, and cooking oil slide further into the field of "ritualized exchanges of food and drink" that are so important to interactions between households as well as the Andean household economy in general (Ibid.: 145-146). For example, when Susana visited Paucará for the Fiesta de Mama Cocharcas, she not only brought large loaves of sweet bread for her mother- and sisters-in-law; she also gave out pieces of fruit to other relatives and friends she met on the street. When Yhosef visited his grandmother, he brought her noodles, sugar, and canned sardines; when he returned to Lima, he brought his family a large basket of chirimoya and avocadoes bought at the trueque in Acobamba, along with an arroba of huayro potatoes (particularly valued for their floury texture), local soft cheese, and charqui bought at Paucará's feria, all valued for their origin in Huancavelica and the "taste of home" (see Sutton 2005). I followed

\footnotetext{
${ }^{25}$ More generally, I observed everyday cuisine as centered on potatoes and other foods produced by the household (chuño, habas, barley, wheat, peas). But while purchased foods such as sugar and noodles appear to be peripheral luxuries, they are in fact integral to highland cuisine: if possible every soup contains noodles and every cup of toasted barley café sugar (cf. Weismantel 1999: 150-151). In contrast, other purchased foods such as rice and chicken do indeed remain marked as foreign, urban, and mestizo on farms surrounding Paucará.
} 
their examples when I brought bread, fruit, sweets, noodles, sugar, and sardines for Tía Verónica and the other family members, and when I sent each family panetones and chocolate caliente for Christmas; however, I was unsuccessful in giving the same breads to Gladys and Frederico in particular because "to offer this type of wanlla to persons who consider themselves one's social superior is to insult them" (Weismantel 1999: 145).

As Weismantel observes for wanlla, the offering of gifts of food and feeding in general "plays an extremely important role in interactions between members of a household, as well as between households" (1999: 146). This is on some level about caregiving and familial solidarity, for mothers especially feed their children, and all family members receive food from the same pot. A child who is learning how to eat will be given spoonfuls from the plates of any older sibling, aunt, uncle, or grandparent present; children who care for their grandmother's sheep are sent home with little pots of savory cooked potatoes. Feeding is prototypically about generosity and human decency: to offer a guest something to eat or drink is the polite and proper thing to do. To not offer to feed a guest is to appear stingy, self-centered, and uninterested in their visit; to refuse such an offer is to say that one does not want to be considered anything but their social superior, for to be fed by another is to be placed in a hierarchically inferior position while being obligated to reciprocate at some time in the future by returning the same act of human decency (in addition to having the opportunity to turn the tables). For example, not wanting to appear ungrateful and stingy, I bought a case of beer for the family that invited me to their farm for the Fiesta de Santiago; Maurelio, the proprietor, bettered me again by giving me a sheep (which would stay in his care and be butchered when I 
returned) and taking a step towards a more formalized relationship through prospective compadrazgo ties.

Gifts of food are essential for sealing these ties of compadrazgo or fictive kinship (see Weismantel 1999: 145). When I agreed to be the madrina for Rosa and Manuel's eldest son's secondary school graduation, they sent me back to Lima with two butchered chickens and two butchered cuyes (one which was cooked for me to eat), as well as an "unofficial" gift or encomienda of potatoes and chuño. In turn, I was expected to buy their son a new set of clothes for graduation and (ideally) attend the graduation ceremony. More significant, however, was the permanent tie created to a well-positioned gringa who (hopefully) sometime in the future will offer their son employment, education, or another opportunity that will lead to his advancement or progreso.

This highlights the idea that social connections, articulated especially through the medium of feeding, are necessary in order to get things done and progresar in the Andes. The notion of the necessary feeding of productive forces will be returned to in the following chapter. For now we will consider the reciprocity and competitive advancement of ritualized drinking structures. While the offering of chicha, trago, and other alcoholic drinks are essential payments made to mountain spirits and hungry diablos (see Allen 2002[1988]; Gose 1994), and while drinking is central to Andean festivals and celebrations in general, in which both men and women drink to excess on occasions such as the Fiesta de Santiago or the Fiesta de Mama Cocharcas (see Allen 2002[1988]; Weismantel 1991), everyday rituals of reciprocal drinking between men are extremely important to sociality and masculinity particularly for those who have moved to the city for wage labour. Here men who have access to cash but not land must create 
and maintain work ties and social bonds with others who are neither family nor members of their home communities. As Norma Fuller suggestively says, "For Peruvian men, circulation among peers is a key strategy to make contacts for future jobs, commerce, services, etc. Thus, the necessity to consume with friends and acquaintances in order to maintain networks of friendship or influences is very important to understanding the masculine culture of work" (2003: 6).

The shared drinking of commercial beer, a common "national" referent, is structured so as to maintain and advance relationships between men through a subtle interaction of competition and commensality. A man will accept an offer of a shared beer if he wishes to acknowledge and renew a social tie; he will reciprocate by buying "the next round" if he does not want to appear stingy and inferior as the "eater" in relation to the "feeder" (see for example Allen 2002[1988]: 123). I characterize this as ritualized drinking because not only are there established behaviors and practices surrounding drinking (for example, drinking from one communal glass in quick succession), but because men know how participating in drinking sessions is important to "advance" their work prospects by being embedded in a set of habitual practices without the need to articulate why (see Ødegaard 2008: 257 on the importance of reciprocal drinking among informal marketers in Arequipa).

Similarly, drinking to excess is closely associated with fertility and prosperity in the highlands, where ritual saturation of various sorts (drinking, coca chewing, eating, music, dancing) nondiscursively reiterates the "practical logical consequence" of wellbeing and abundance that is the hoped-for outcome (see Allen 2002[1988]: Chapter 6). This nondiscursive force of feeding will be returned to in the following chapter. For now 
let us note that the overconsumption and even "forced" ${ }^{26}$ consumption of alcohol in the city has much in common with the "progressive" force of feeding. Thus men who drink in the city may not just be attempting to momentarily forget their problems and their inadequacy as primary household supporters, or add spice to the daily grind (as is sometimes obviously the case), but often also have expectations for beneficial outcomes (both symbolic and practical) that may be more or less articulated. (For example, in purposefully creating or strengthening a work relation, or in habitually playing out the logic of feeding and overabundance that is the "practical consequence" of the circulation of life-giving energies in the highlands).

Another aspect of such drinking rituals is the implied commensality in drinking from the same communal glass. Here the implication is that those who drink (and eat) the same substances together are of the same (communal) body (see for example RobertsonSmith 1927[1889]: 265; Counihan 2004: Chapter 7). Births, weddings, funerals, and other life-cycle familial and social events are ideal situations in which to observe the articulation and renewal of community membership through feeding. I had the opportunity to attend one such event when Jaime, the husband of don Pedro's one sister living in Lima, invited me to a pichja in Chacapampa. The pichja ("five") occurs on the fifth day after a death (preceded by two days of velorio or wake in the house of the deceased and the burial and vispera at the cemetery), when the deceased's clothes are washed in the Río Wichjana, and the relatives of the deceased share a meal with the deceased's soul.

\footnotetext{
${ }^{26}$ More than once I observed and experienced the difficulties of refusing a drink; the "feeders" are highly persistent and persuasive, and even more so as the "saturation" progresses.
} 
Jaime had traveled from Lima with his aunt specifically to attend the funeral, presumably of a family member. I met him on the road on my way to Verónica's house on a day I arrived back from Huancavelica, and I accompanied him, Lidia, and Jeremiah to the pichja, where we met Verónica and Teofilia. He told me that it was at the Río Wichjana, but we did not travel all the way down to the valley, but rather settled outside of Chacapampa at what must be a tributary stream that appears in the rainy season. When we arrived, it was around two o'clock in the afternoon, and many mourners were already present, seated on one side of the stream quietly chewing coca, smoking cigarettes, and sharing glasses of trago and carbonated drinks. Most of the deceased's clothes were already washed and laying on the opposite side of the stream drying, probably washed by the deceased's in-laws as described by Gose (1994: 117-121).

After about an hour, more relatives arrived with large pots and buckets of food, which they set up on the hill above the drying clothes. Rosa later told me that each relative - a mother, sister, or daughter - will each contribute a dish. As more people arrived, relatives on the "wet" side of the stream crossed to those seated on the "dry" side around the cooking pots, offering the relatives and visitors trago and gaseosa. Eventually those organizing the pichja started to prepare to serve the food, and everyone crossed the stream to be seated on the hill overlooking the stream.

Men gathered all the clothes into five piles, wrapping them in blankets and setting them in a line parallel to the stream. The deceased's spade, shovel, and staff were placed in the ground in front of them, and two men with leather whips stood behind. What their purpose was is unclear, although they did use the whips to scare away the occasional dog - creatures which are associated with the process of death (see Gose 1994: 123-124). 
Five blankets were then stretched in a narrow line perpendicular from the clothing bundles, with a ritual specialist at the head and the women with the food behind. Main relatives then sat on either side of this "table," with men on one side and women on the other, calling other relatives who may or may not come over, who were sitting a distance away by the cooking pots. (A sixth blanket was taken from the clothing bundles to accommodate all the people).

Five dishes were then served. First there was a thick soup of barley, peas, carrots, potatoes, and herbs. This was followed by a savory dish of peas and potatoes. Next was a yellow pea and barley soup. This was followed by another savory dish of peas, carrots, cabbage, and potatoes served with rice. Last was a tallarin of spaghetti noodles in a red carrot sauce accompanied by savory potatoes, peas, and carrots. Women who brought the food dished it out while men handed out the filled bowls, running back and forth between the "table" and various pots to collect the used dishes, have them rinsed and refilled, and then serve someone else. The servers soon run out of spoons and I am fortunate that Verónica, whom I am sitting with, has brought one. As the dishes are served, first to the men and women at the table, and then to other people (mostly women and some children) seated so the side, a man brings bags of boiled chuño to the table, calling out the names of the people who gave them as their voluntad, to which guests give their loud and enthusiastic thanks, before sprinkling them on the blankets. Some people have also donated bags of cancha de trigo (puffed wheat, a popular snack), and another some bowls of aji (hot pepper sauce) to accompany the chuño.

People at the table take some chuño for themselves or for relatives seated elsewhere. Verónica has obviously planned ahead and has a cloth to wrap the chuño in to 
save for later. She also has plastic bags and a little pot for the rest of the dishes which we cannot finish (which is most of the food). Indeed, I wonder how people can finish their dishes so quickly and take on another heaping dish with such gusto, but I soon see that many are redistributing their bowls to children nearby or relatives seated elsewhere. Perhaps there are others also hiding baggies and pots in their mantas?

As the meal is almost over, the men in charge note that it is five o'clock. Presumably it is time to wrap up the meal and head over to the deceased's house for an additional all-night wake or visit. The meal finished in its own time anyway, and Verónica leaves with the other guests, bringing coca and candles.

A large public meal must pose a considerable cost to the relatives of the deceased, which perhaps accounts for the absence of meat in the dishes, but which does not diminish the compulsion to provide food in overabundance. Other public meals are more overtly about the conspicuous display of wealth, such as the midnight meal or lonche $e^{27}$ provided by the mayordomos for the Fiesta de Mama Cocharcas. Here the sponsor must feed a hundred or more people a complete meal without charge, including sopa and a segundo, which is explicitly judged as being generous or rich enough on account of the expense. The lonche I attended included a dish of rice, potatoes, and spiced meat, which was thought to be cheap as there were not generous enough servings of meat, thereby diminishing the mayordomo's claim to overabundance so integral to fiesta sponsorship.

As this indicates (and as suggested occasions above), the individual who is providing food by "feeding" is making a claim to a hierarchically superior position in relation to the individual who is receiving the food and eating. This can be seen in the

\footnotetext{
${ }^{27}$ Lonche normally refers to a light dinner of tea or café with bread, often eaten late at night. "There's no sopa tonight, only a poor lonche," Susana would say for example. Its ironic use here seems to highlight its actual goal of overabundance and overprovision.
} 
longstanding Andean work relation of mink'a, in which the proprietors offer food and drink to workers who labour in their fields, in the process demonstrating "wealth and power" in contrast to the "need and dependency" of those who must work for food (Gose 2000: 86; see also Gose 1994: 7-11). In distinction to ayni, which Gose identifies as a force of equalization since the proprietor-host will reciprocate in the future by labouring in the worker's fields, mink' $a$ maintains an asymmetrical social ordering because the proprietor will not relinquish his or her superior position as feeder by performing reciprocal work (1994: 8-9). As we have seen above, ayni-like reciprocal feeding can also operate as an equalizing force between individuals who compete so as to not be outdone by the other; in the interim however, it seems that the default position is the social superiority of feeder over eater.

Thus when Rosa and Manuel invited me to observe them planting their potato field, they fed me lunch but did not allow me to work: "People will think that we only fed you because you worked," they said. For them, I was an honoured guest and comadre, whom they should have the prestige of feeding without expecting labour in return, while remaining in other ways their social superior. As this indicates, the social claims and implications of feeding are by no means unambiguous. In any case, to provide food is gain prestige, and to accept food is to participate in bestowing it.

This can more clearly be seen in the independence and power that women (especially older women) exercise through their control of the kitchen and the provisioning of food. Indeed, I at first found it difficult to understand why Mamaku consistently wanted to feed me, given that we could not verbally communicate (I spoke no Quechua and she no Spanish), and as far as I could tell she did not actually like me. 
Eventually I realized that feeding others is one of the few ways remaining in which she can exert her power over another, demonstrate her (fierce) independence, and gain prestige. Similarly, Teofilia reserved her eggs to feed me herself, rather than exchanging them with her sister Verónica, who would then gain the prestige of feeding me a homeproduced treat (here not in the sense of wanlla, but in the sense of an uncommon enough food that is the materialization of a good deal of investment in the household economy). For her part, Verónica never missed an opportunity to feed me rarities and seasonal home-produced products such as charqui or fresh milk curds.

I will never forget the day she butchered a sheep with Mamaku to make into charqui for her son's upcoming wedding in Lima. Almost nothing was thrown away: the hide was cleaned and dried on the line for a sleeping mat alongside the quartered and salted carcass hung to dry; the blood was collected and reserved to make a delicious sort of cooked spiced pudding; and the esophagus, stomach, liver, intestines, and other organs were cleaned and roughly chopped to be made into caldo de panchito (tripe soup). This was considered a delicacy and was enjoyed with gusto by Verónica and Mamaku; I was disinclined to the taste of tripe, but especially the rubbery texture which makes the pieces difficult to chew without swallowing whole. ${ }^{28}$ When Verónica and Mamaku saw that I was only pushing the pieces around in my soup bowl, more was heaped on with the admonishment that I would "morir de hambre" in what I thought at the time was some

\footnotetext{
${ }^{28}$ Texture is as aspect of the embodied experience of taste that is given only perfunctory attention by David Sutton in his nevertheless outstanding extended anthropological meditation on food and memory (see for example Sutton 2001: 99). I have often thought that texture plays a not insignificant role in Andean cuisine and taste, having repeatedly observed a preference towards soft-textured foods that are cooked in boiling water (by some standards, overcooked) and "floury" potatoes (see for example Weismantel 1989: 90-92; Ossio 1993: 102-103, 106). Indeed, on one occasion Susana's daughter was scolded for "undercooking" a tuber-based dish, which was of completely acceptable consistency and taste to my culinary experience.
} 
sort of punishment. I realized even then that it would have been disconcerting - indeed, insulting - to them to have such a treat refused.

Verónica and Mamaku did not forget my distaste for caldo de panchito the next time it was served, and although they accommodated me graciously enough, neither did they absolve me from the obligation of eating a bowl. Here I follow David Sutton (2001) in suggesting that part of the persuasive influence of these various feeding contexts is connected to remembrance: memory of meals past and of prospective ones to come in an annual- or life-cycle, of food exchanges completed or in process, of a reputation created by proper provisioning (even over-provisioning) and perhaps not so appropriate receiving of dishes. Such remembrance continues to have persuasive influence in the role that feeding plays in production and market relations in both rural and urban settings. 
Plate 4.1

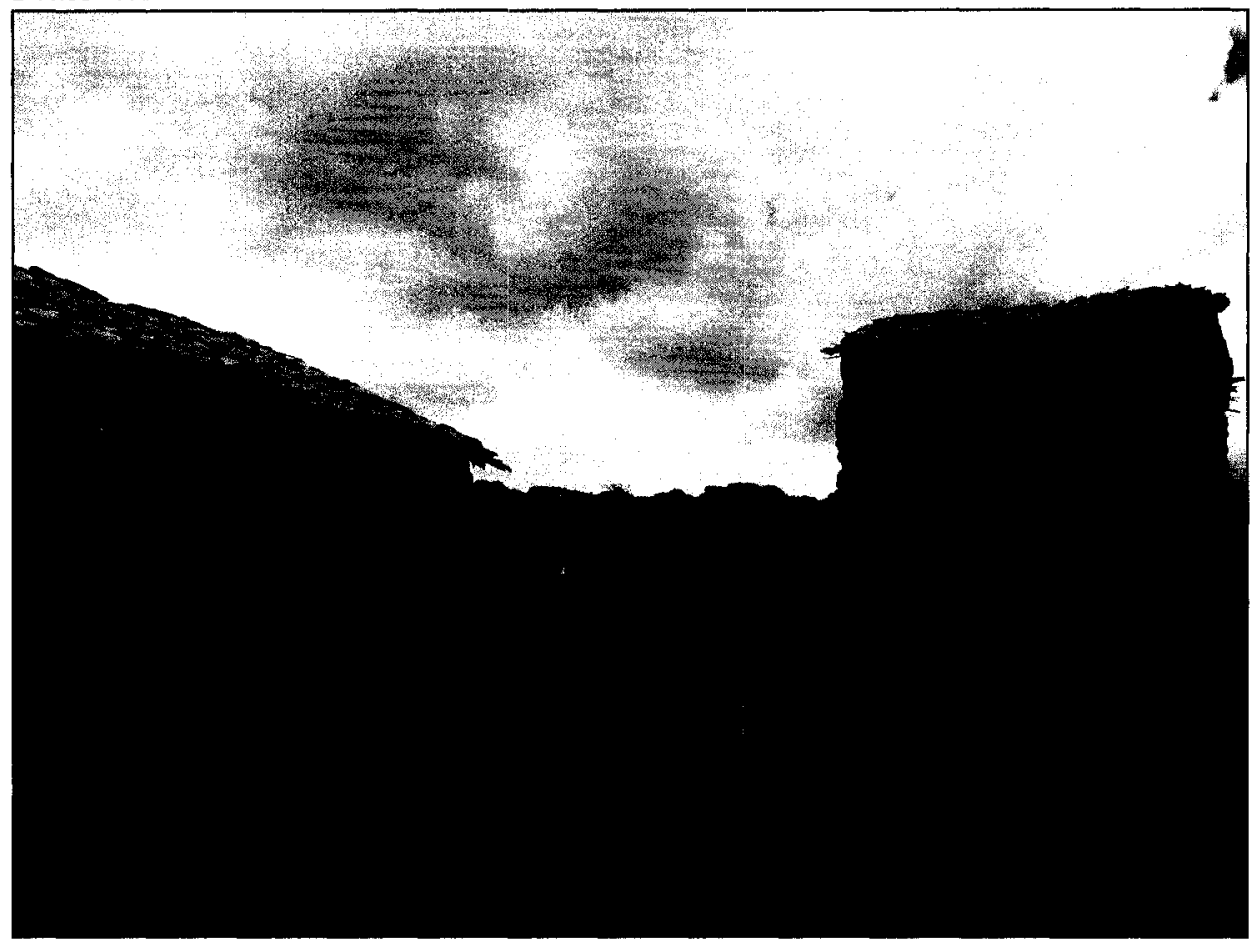

Veronica's courtyard, with bedroom to the left and kitchen to the right. Paucará, September 2007.

Plate 4.2

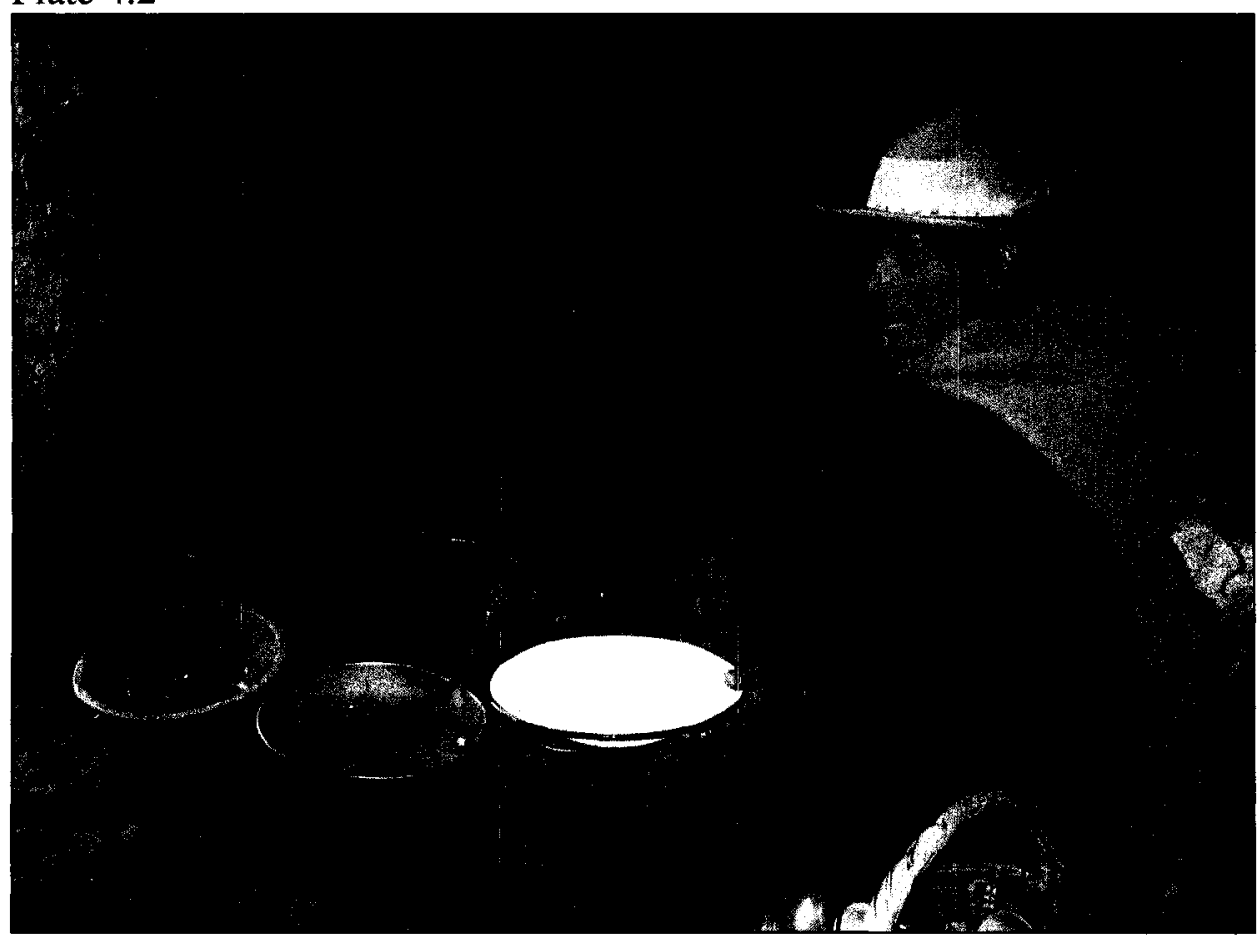

Verónica serving the daily sopa. Note clay dung- and wood-burning stove in background. Paucará, September 2007. 
Plate 4.3

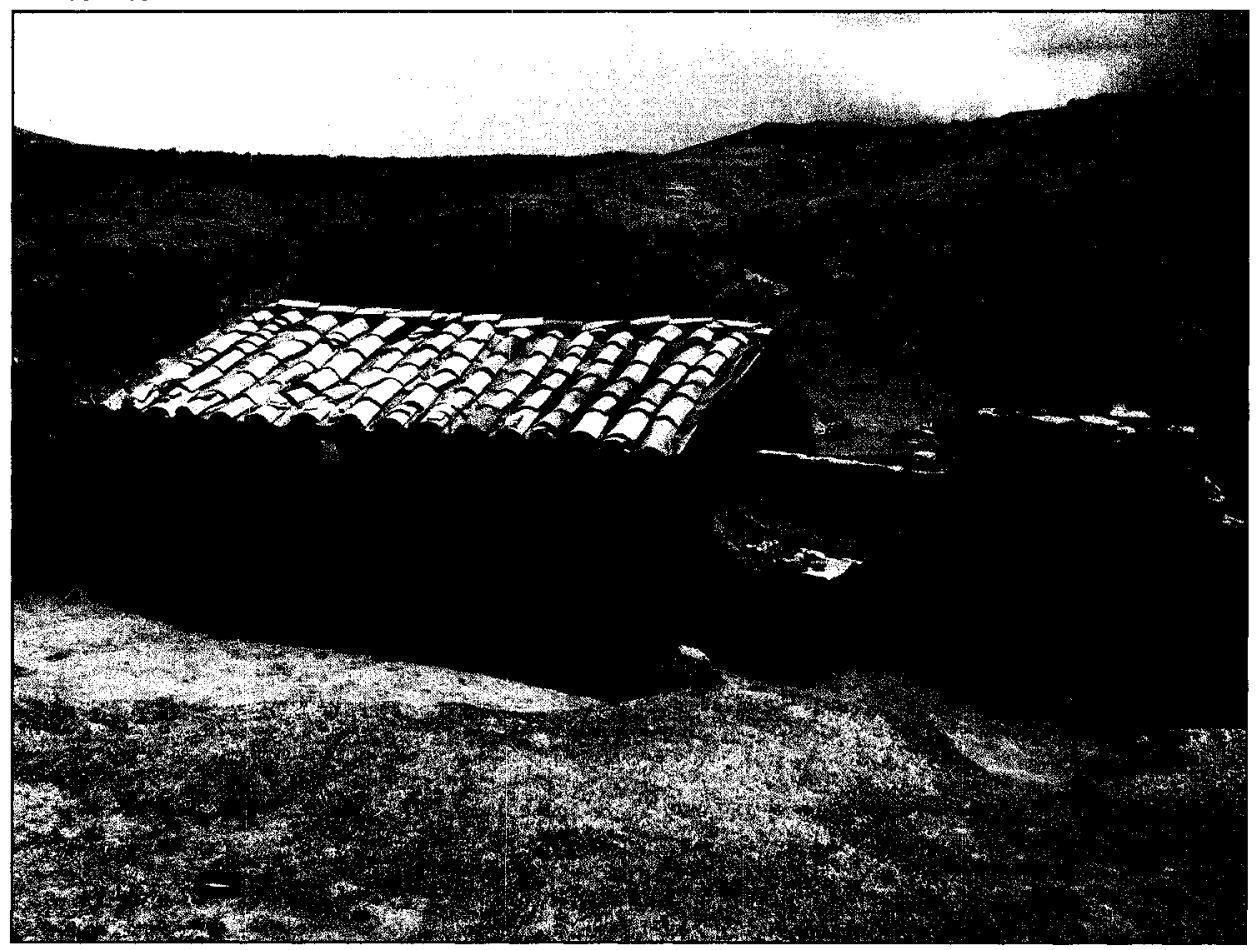

Lidia's kitchen, with gate facing Verónica's house. Paucará, September 2007.

Plate 4.4

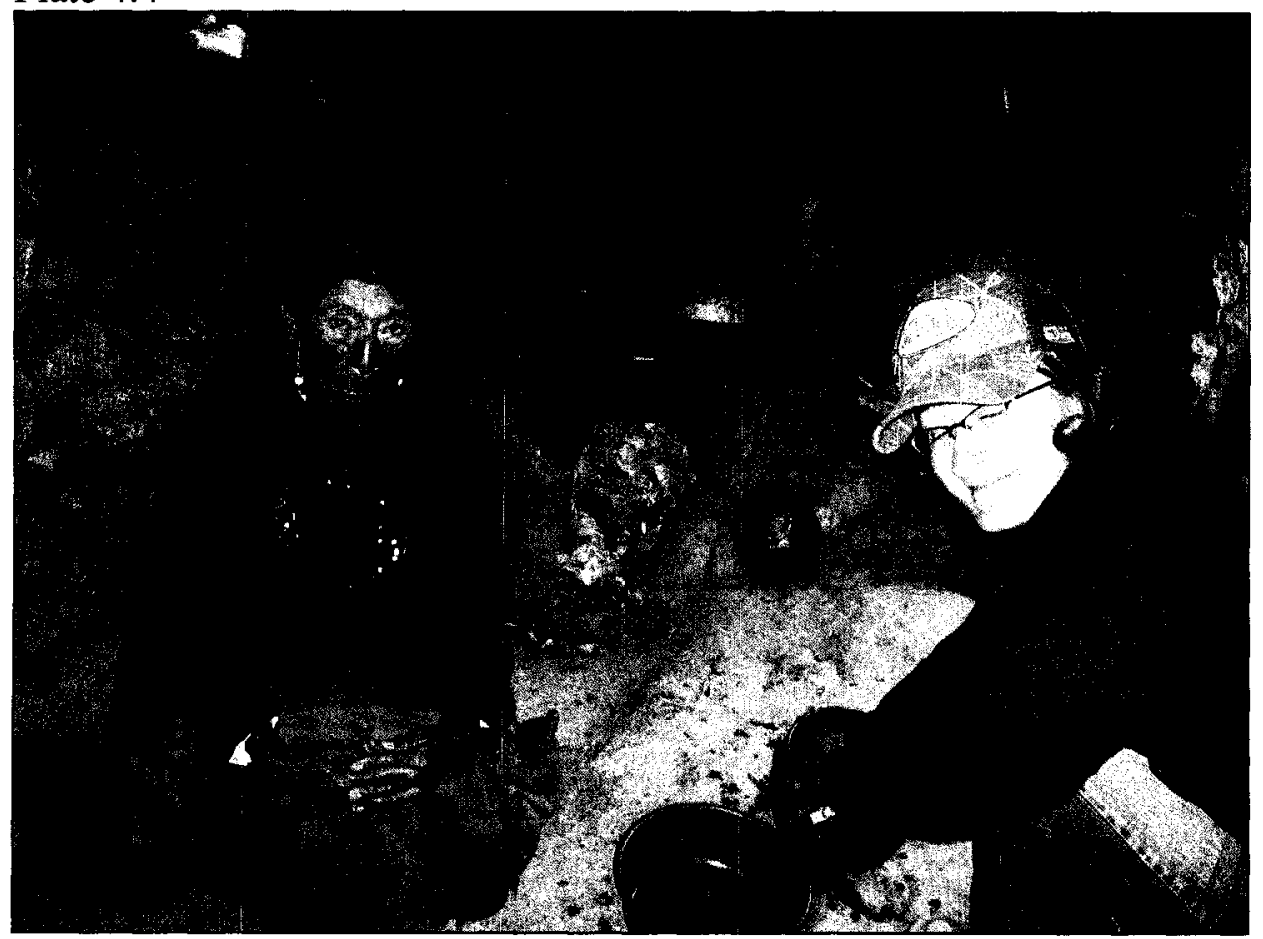

Washing dishes in Mamaku's kitchen. Paucará, September 2007. 
Plate 4.5

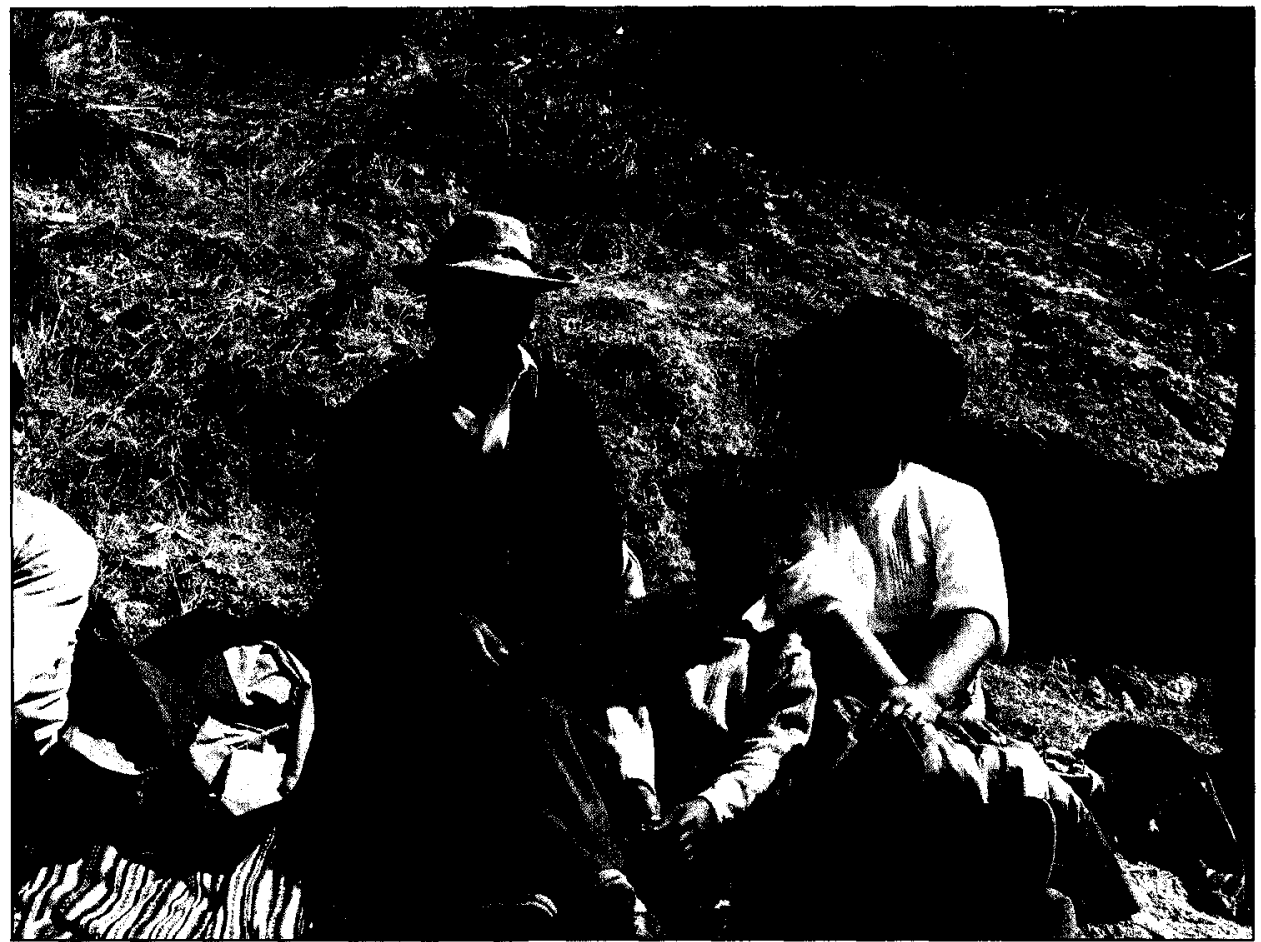

Pedro's distant cousin Frederico, with wife and youngest son at the Correo de los Torros. Paucará, September 102007.

\section{Plate 4.6}

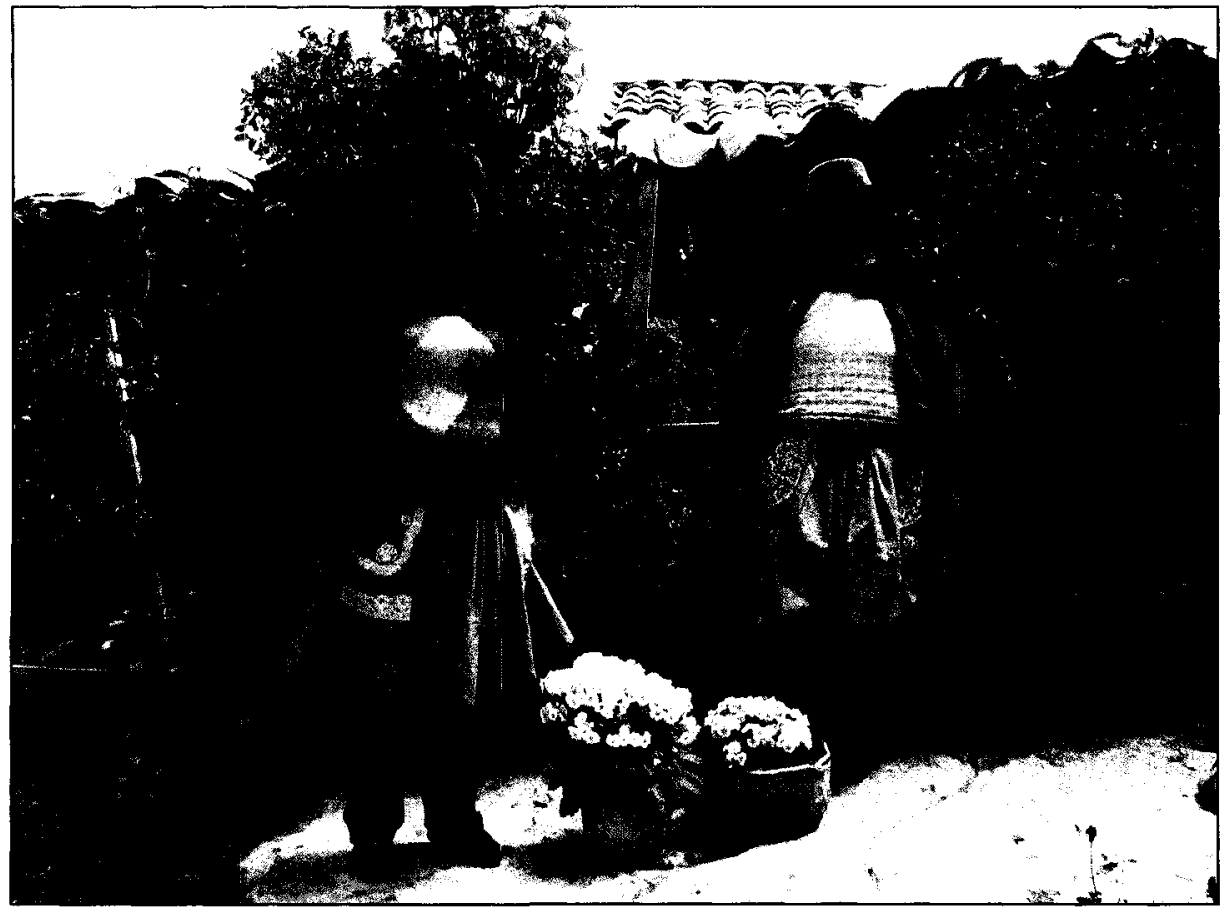

Pedro's distant cousin Gladys to the right in her courtyard with a neighbour. Paucará, September 2007. 


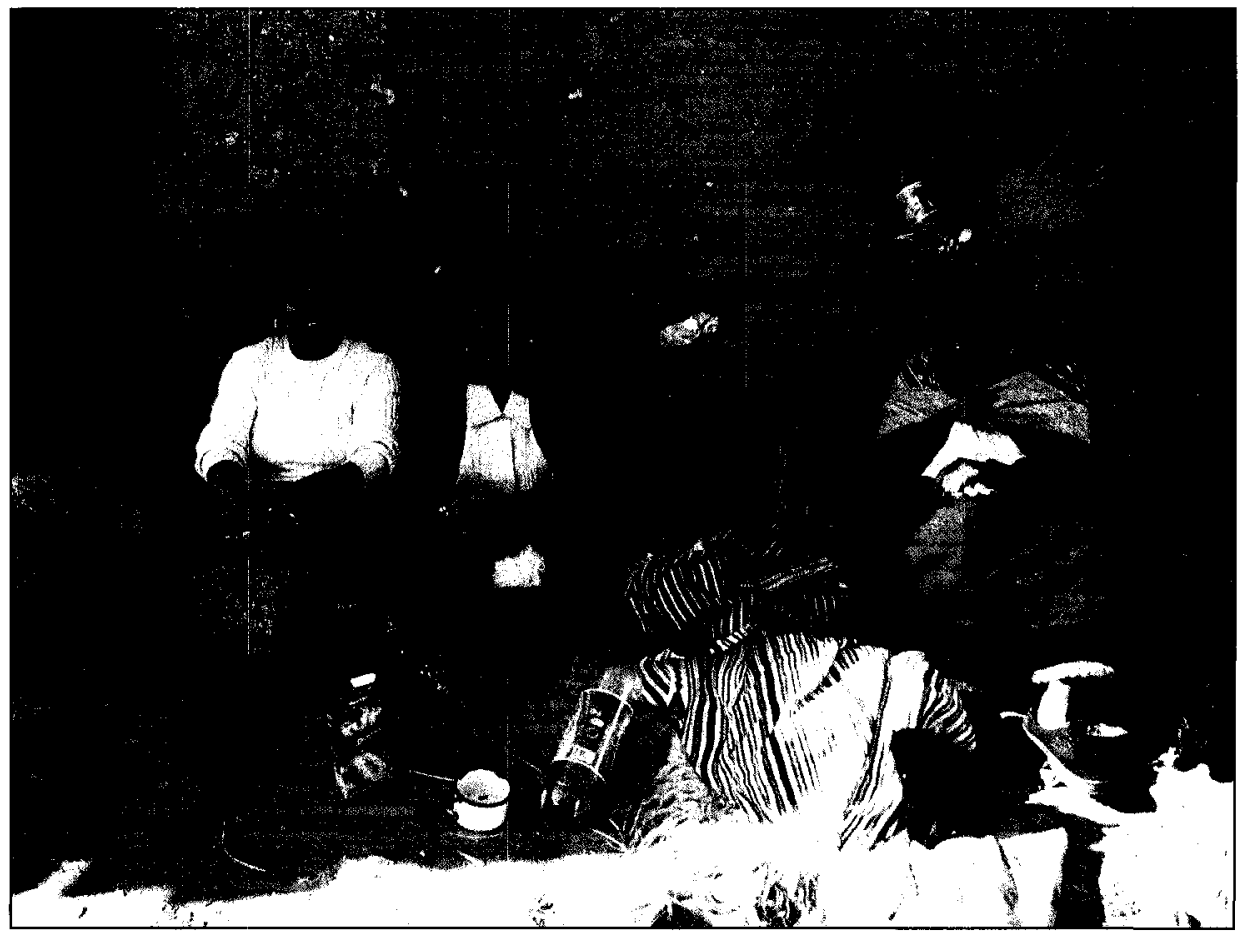

Relaxing in the courtyard with treats brought from town. Susana, Teofilia, and Mamaku relaxing in Verónica's courtyard. Paucará, September 62007.

Plate 4.8

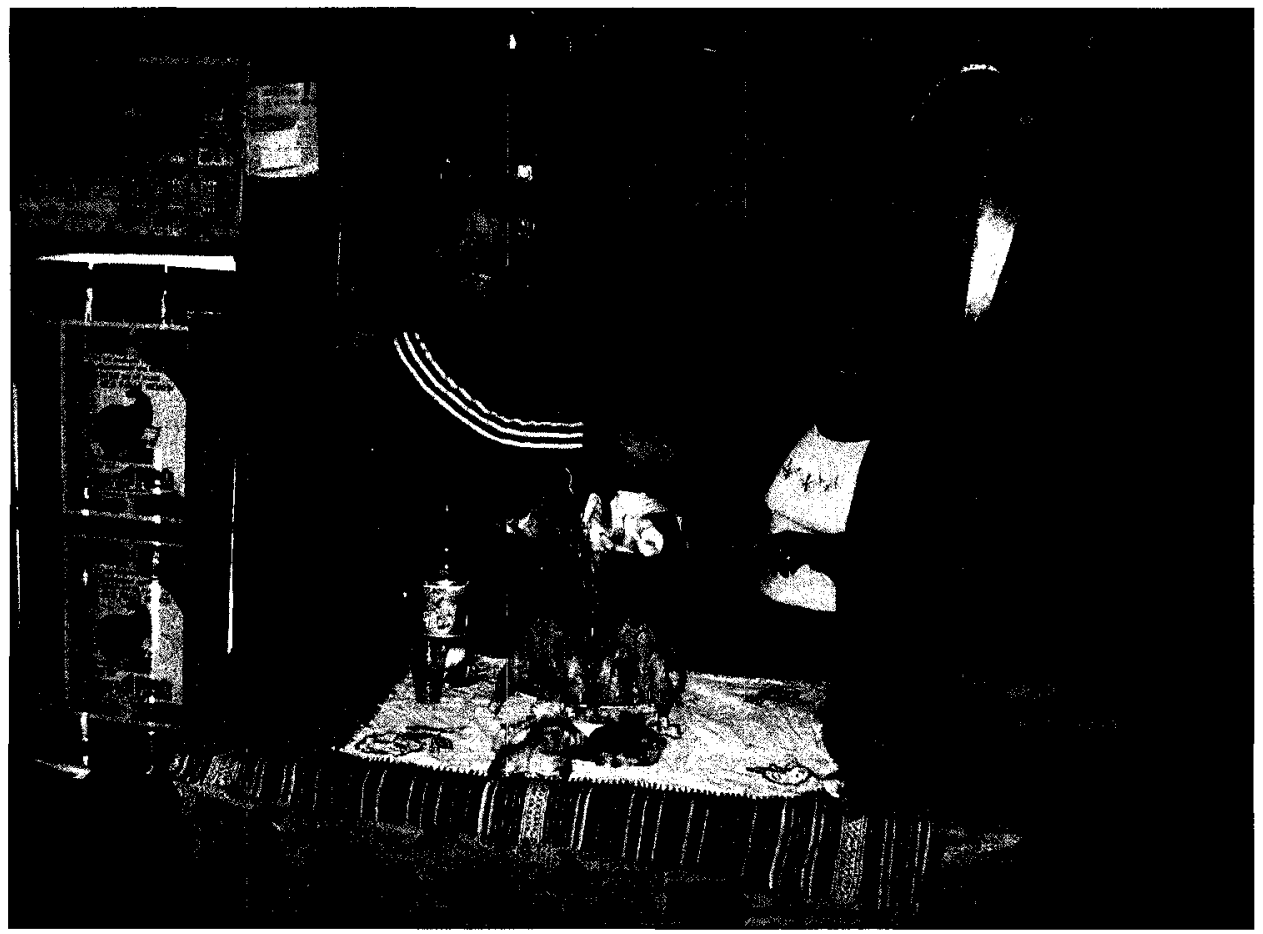

Food is used to seal ties of compadrazgo. Rosa presents the ethnographer with two gallinas and two cuyes to formalize their relationship as comadres. Chacapampa, November 302007. 
Plate 4.9

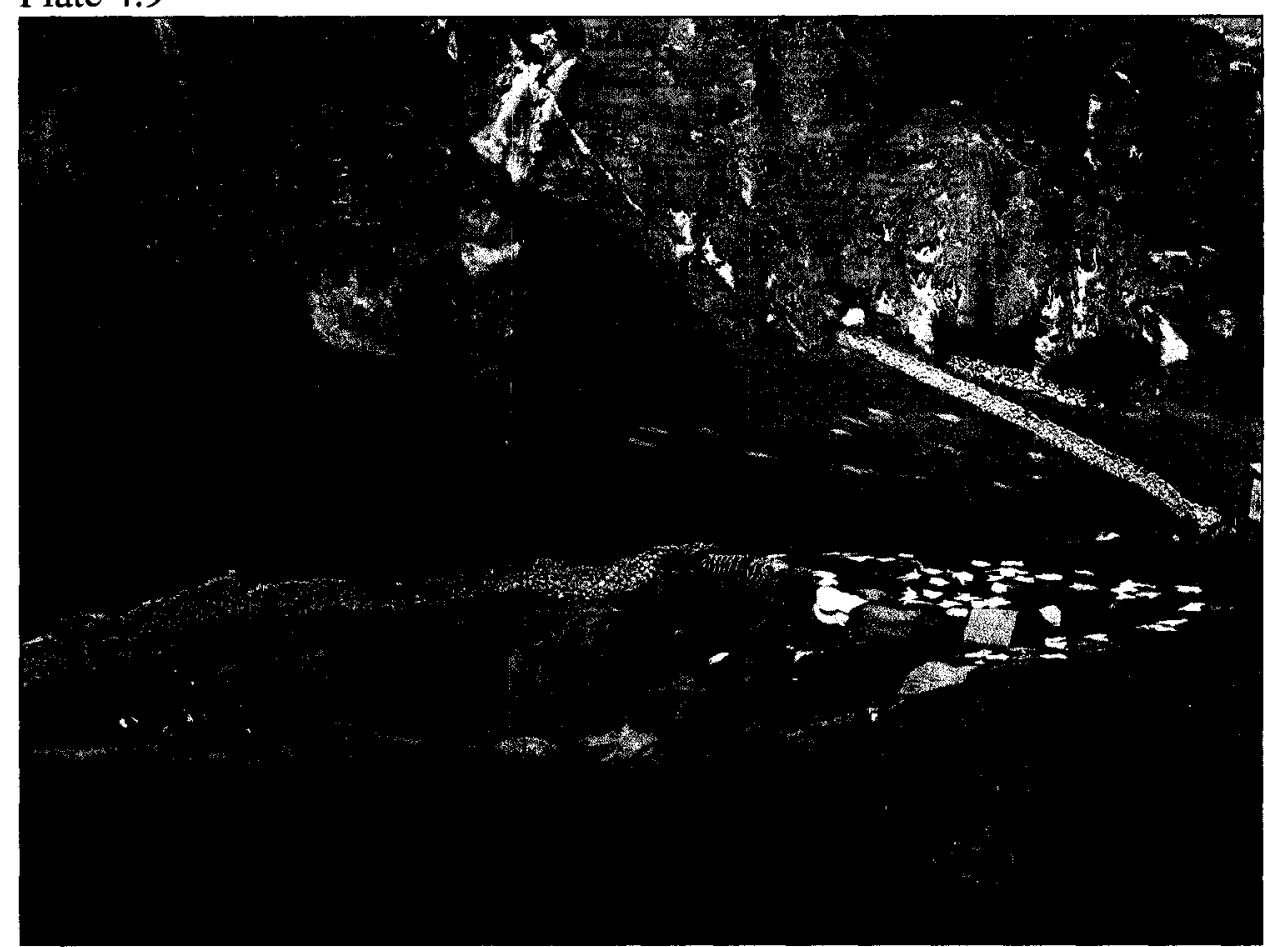

Mourners washing clothes of the deceased at a pichja. Chacapampa, January 302008.

Plate 4.10

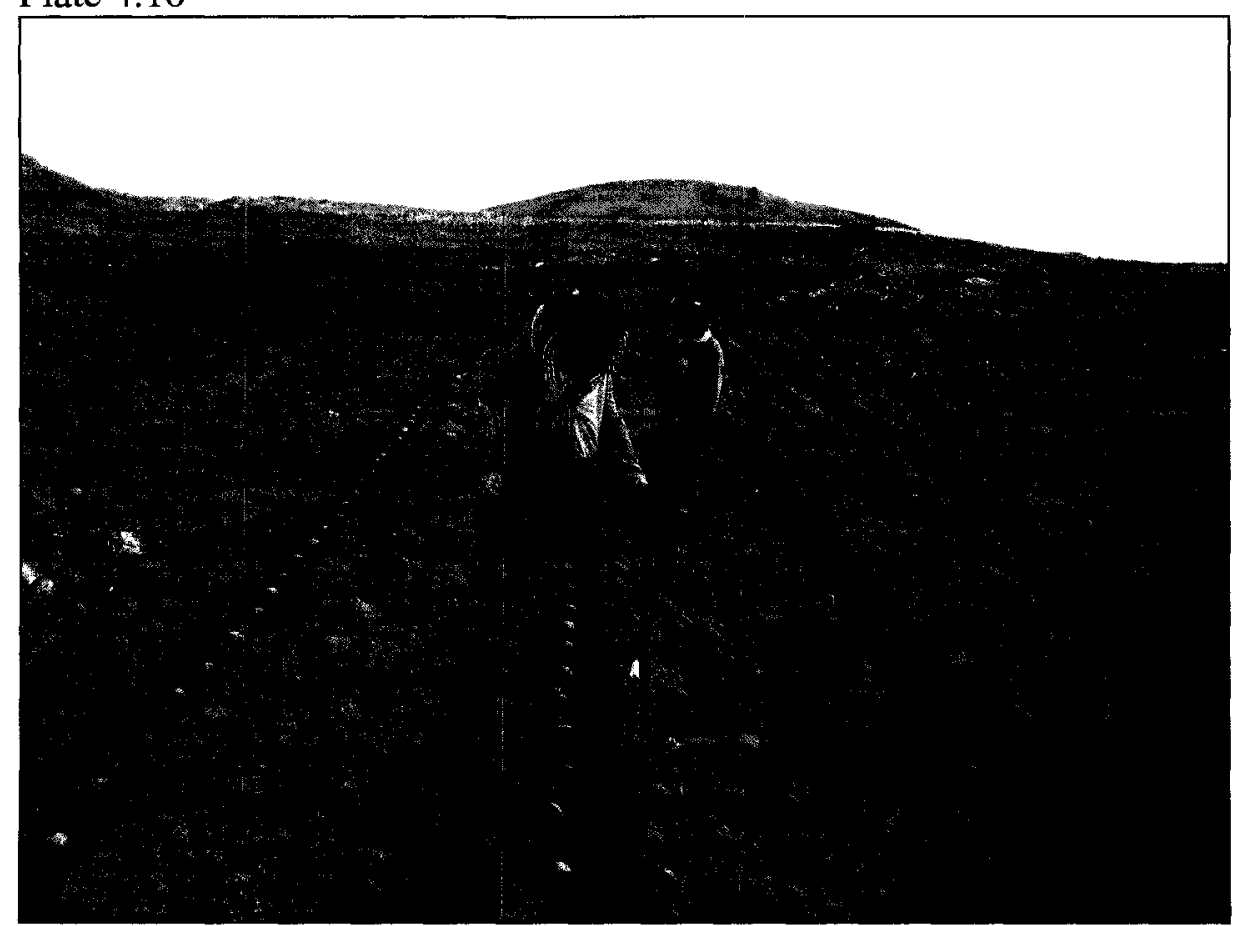

"People will think we fed you only because you worked." Here the ethnographer places fertilizer on seed potatoes "just for a picture," joined by Rosa's youngest daughter. Paucará, November 282007. 


\section{Chapter 5: Feeding as a Force of Production and Advancement}

Repetimos que en las comunidades Anccaras y en los Andes en general, todos los miembros del ayllu "comen": las plantas, los animals, la gente, el granizo, los difuntos y otros... Los Apus también moran en ayllu, al darles comida (a través de los ofrecimientos rituales), no se puede hacerlo a uno solo de ellos; tiene que ser para todos, puesto que cada uno cumple su rol dentro de la comunidad.

We repeat that in the communities of Anccaras [Huancavelica] and in the Andes in general, all the members of the ayllu "eat": plants, animals, people, hail [i.e. elements of the climate], the dead, and others... The Apus also dwell in the ayllu, and the feeding of them (through ritual offerings) cannot be directed towards only one of them; it must be for all so that each can complete his [or her] role in the community. (Zevallos, Zevallos, and Huincho 2004: 45; my translation).

The theme of feeding permeates the ethnographic literature in the Andes, although to the best of my knowledge, few studies are focused specifically on the symbolic significance and practical domains of feeding (suggestive places to start from a culinary perspective include Olivas Weston 1993, 1998, 2001; Skar 1994; and Weismantel 1988, 1989, 1999). One could even say that "feeding" is a key cultural metaphor. Feeding and its place in cuisine ${ }^{29}$ is a common thread present in various aspects of Andean life, and as such makes a suitable (and interesting) viewpoint from which to regard production, market, migration, and ritual relations. From a political-economic perspective, feeding perhaps is not the most relevant thing that brings these themes together. However, by using feeding as a common frame of reference for a symbolically inclined analysis, I believe some insight (in the Gadamerian sense) can be brought to light. I will follow Gose (1991) in considering the nondiscursive meanings that are generated through social practices surrounding feeding. As Gose indicates for Andean house rethatching, the

\footnotetext{
${ }^{29}$ I follow Weismantel in defining cuisine as "the cultural construction of meals, the structures that organize knowledge about foods, and the pattern of their preparation and combination" (1988: 87) - to which I add the patterns of presentation (distribution) and consumption.
} 
praxis of food and feeding can be contradictory, but precisely because feeding cannot be contained in a unidirectional analysis (an "objective" fiction in any case), some richer understanding is to be gained by exploring its connections to larger frames of reference. While Gose considers house rethatching in the context of the annual agrarian cycle, I will attempt to contextualize feeding by considering the practices and thought surrounding it in relation to the places that Andeans inhabit and which contextualize (indeed, form the ground of) their life experiences (see Gadamer 2004[1975]; Dostal 2002; Casey 1996).

Feeding is integral to agro-pastoral production in both the practical and symbolic sense: the labour of others is accessed primarily through the feeding of agricultural workers under Andean labour models (e.g. ayni, mink'a), and the ritual feeding of autochthonous powers (e.g. mountain spirits, the pachamama) is necessary to ensure fertile and productive crops and herds.

Many ethnographers testify to the ubiquity and importance of the distinctly Andean work models of ayni and mink'a (see for example Allen 2002[1988]; Gelles 2000; Gose 1994; Harris 1989; Isbell 1978; Mitchell 1991; Paerregaard 1997; Weismantel 1991). Here the worker may be placed in an egalitarian (ayni) or hierarchical (mink'a) position in relation to the proprietor, in which like work may be performed for the labourer by the proprietor at some time in the future (ayni), or in which the proprietor does not reciprocate (mink'a); in addition, workers may sometimes be compensated with a nominal monetary payment (as in jornal), or they may hope to initiate a prospective reciprocal relationship with the proprietor (as in yanapa) (Gose 1994: 8-9; Allen 2002[1988]: 72-73). In all of these cases, however, labourers expect to be compensated with food and drink for a day's work (Gose 1994: 8-9). 
Ayni, mink' $a$, and related Andean work patterns accompany work-intensive tasks and communal structures such as field preparation, house construction, and canal cleaning (see Allen 2002[1988]; Gose 1994; Paerregaard 1997). Large work parties in which labourers are compensated with food and drink (especially chicha) prepared and served by women are supposed to (according to the ethnographic literature) characterize the "typical" Andean agrarian economy in which campesino labour is pooled at certain times of the year or for particular tasks, with the maintenance of individual households in mind at the same time as the reconstitution and strengthening of community membership and solidarity (cf. Annis 1987).

Although I did not observe obvious ayni or mink'a labour work parties in Paucará, informants told me that such work relations do in fact exist. Manuel told me that were he to hire peones to work his fields, he would have to provide coca, trago, and cigarettes for their three or four breaks throughout the day, food for the fiambre, and a fee of S/. 10 per day (a nominal wage from the worker's perspective). He did not, however, hire peones to turn over a fallow field in which he was planting potatoes; nor did he seek out reciprocal help to plant his barley, oats, or potatoes. Like seemingly every campesino I observed throughout the planting season (September-November), Manuel prepared the field by himself and planted it with his wife. In this, he was actually "helping" his wife, as he was using her field; the harvest would be "his own," although if the two did not comprise the same household, he would probably be obligated to cede a portion of the crop to the field's owner.

The only person who I observed soliciting a worker was Verónica, who for lack of a husband or son living at home, paid a young man from another community S/. 10 to 
turn over her field at some personal hardship. He must have been even poorer than she, and was given a bowl of mazamorra with an air of pity because he had probably not eaten at all that day. It is conceivable that she hired a peon (with money sent from her children in Lima) rather than arranging an exchange with Manuel or another relative to do the work for her as she wanted sole ownership of the crop; she probably relies on this small field of potatoes and oats for bare subsistence for most of the year. For his part, Manuel would bring more fields under cultivation if he could afford to hire workers (and if he had the means to transport the harvest back to his home). Thus, in contrast to the apparently predominant idiom of ayni in the Andes, work in exchange for food and drink and/or like work is not sufficient to access labour for subsistence farmers and semiproletarianized campesinos in Paucará.

Since Paucará is situated at an elevation too high for corn production (3806 masl), fields are predominantly non-irrigated. The dominance of rolling high-altitude hills also means that there is very little terracing required. Perhaps the absence of work-intensive communal structures such as irrigation and terracing partially explains the apparent absence of ayni work patterns so important to the peasant economy in other areas (see for example Gelles 2000; Gose 1994; Isbell 1978; Paerregaard 1997), as is indeed more characteristic of high-altitude pastoral zones (Gose, personal communication).

An additional factor is likely a general breakdown of social solidarity and trust in the wake of the violence and social fracturing of Sendero Luminoso (Shining Path), which pitted Andean communities not just against the Maoist-inspired guerilla army and the state, but also neighbour against neighbour and family member against family 
member. ${ }^{30}$ The department of Huancavelica experienced a similar (although less intense) trajectory of political violence as the adjacent senderista origin of Ayacucho, with periods of heightened violence between 1980-1983 and 1989-1992 (Manrique 1998: 194195).

During the war, Huancavelica was situated in between Ayacuchan senderista strongholds and the strategically important Mantaro Valley in Junín, ${ }^{31}$ with its important hydroelectric lines running to Lima, close proximity to important mining centers vital to the national economy, and strong student support out of the Universidad Nacional del Centro in Huancayo (see Manrique 1998: 196-199). Moreover, essential transportation routes run through Huancavelica from Ayacucho to Huancayo, which itself is in "an important crossroads for routes that connect Lima with the southern sierra and with the central and northern selvas (the jungles that adjoin the eastern mountain slopes)" (Manrique 1998: 199). During the height of the "people's war," the central selva was a strategic zone of senderista expansion, as well as an important area of connection to drug traffickers (Manrique 1998: 214-215). (Today, the city of Huancavelica is considered a hub of cocaine trafficking from Ayacucho to the selva).

Finally, although the lack of workers was often given as a reason that ayni was not being solicited at the moment, and although informants consistently responded that they did indeed do ayni (despite my observation that siblings would not even lend one another tools), perhaps Paucareños are compelled to believe that they do such reciprocal

\footnotetext{
30 "In addition to the political violence unleashed by the subversive organizations [e.g. Sendero Luminoso and its Leftist rival the Movimiento Revolucionario Túpac Amaru, MRTA] and the Armed Forces, people took advantage of the climate of generalized violence to settle scores that had little or nothing to do with politics" (Manrique 1998: 200-201; see also Skar 1994: 128).

${ }^{31}$ Indeed, the community of Chucupata in the department of Junín (which I visited for the Fiesta de Santiago; see Chapter 2) is situated on the edge of the Mantaro Valley, in an area that experienced violent and repressive Sendero Luminoso activity and military counterinsurgency from 1988-1990 (see Manrique 1998: 202-208).
} 
work exchange because reciprocity is so central to sociality and human decency in Andean society. To admit that one does not do ayni may be to admit that one is not a moral social actor, or indeed a runa. ${ }^{32}$

Nevertheless, reciprocal exchanges involving food and drink remain important to "getting things done" and "progressing" for Paucareños in both rural and urban settings. In general, feeding makes a social claim (e.g. to status; to having a relationship; to family or community membership), but often at the same time attempts to push the recipient towards a desired goal (e.g. the socio-economic opportunities hoped for in a relationship of compadrazgo that is sealed with food). This is remarkably similar to the force of ritual plates offered to mountain spirits observed by Gose:

[T] he t'ika plato confers an honour upon a local mountain spirit, but also pushes it towards a very specific agricultural function. (1994: 215)

The ritual feeding of hungry mountain spirits and the pachamama figure prominently in the agrarian cycle: at the herranza (the Fiesta de Santiago), yarqa aspiy (canal cleaning), and through a series of t'inkas (libations), despachos (burnt offerings), and other household rituals throughout the year, these divine powers are fed with coca, chicha and other types of alcohol, cigarettes, and even dried llama fetuses so that each will "complete his role in the community." Zevallos et al. and other Andean researchers further emphasize that in addition to the mountain spirits and the pachamama, other forces and figures in the lives of runa - such as elements of the climate (hail, wind, lightning), puquiales (natural springs), the condor, sarna (scabies), the house, the dead, and even gentiles - must receive ritual payments (each with its own preferred foods), for

\footnotetext{
${ }^{32}$ I am indebted to Peter Gose for this insight; see Gose 1994 on the importance of ayni for "commoner" relations and the contrasting refusal to participate in ayni work exchanges on the part of "notables."
} 
they are hungry as well, and require feeding to be productive (or at least not life-draining) members of the community (Zevallos et al. 2004; Cutipa et al. 2004).

When properly fed through ritual offerings or payments, the hungry mountain spirits and pachamama bestow life, vitality, fertility, prosperity, and health upon the runa under their tutelage. They are not just the physical terrain upon which people plant and pasture; they are also the underground or inner $(u k u)$ sources of the water that is essential to make plants grow and give them vitality. This is not significant in an ecological sense so much as in a cosmological one, for water is the concentrated embodiment of sami, the essential life-force or energy that is in constant circulation between the mountain spirits, plants, animals, people, and other emplaced forces. Sami ${ }^{33}$ is the animating essence "inherent in all matter," and through ritual feeding (e.g. libations of chicha, offerings of coca, maize, and other consumables), its flow can be ritually directed from the mountain spirits to the earth and humans (see Allen 2002[1988]: 34). Indeed, Allen suggests that in addition to ritual libations and offerings, ritual consumption in the over-consumption and even forced consumption of food and alcohol is about the sharing and circulation of sami. This is one reason why intoxication, as a kind of ritual saturation, is a desirable state: it is a "fullness," a "spilling over," and an "exuberance" indicative of sami (Allen 2002[1988]; see also Weismantel 1991).

According to Gose's exegesis, sami is concentrated in the water that is extracted from the dead residing underneath the mountains in a process of dehydration; through rainfall and irrigation it resurfaces to give life and robustness to plants (Gose 1994: 123-

\footnotetext{
${ }^{33}$ Here it is important to note that not all Andeans have such a well-developed articulation and use of the concept of sami as do Sonqeños (see Allen 2002[1988]). However, as I will attempt to demonstrate below, it is evident in practice that the underlying force of circulation inherent in the logic of sami is of widespread significance in the Andes (see for example Gose 1994; Skar 1994).
} 
131). The plants in turn convert this powerful force $-\mathrm{a}$ force that is dangerous in its "raw" or unmediated state - into a form that is consumable by humans, and which in turn will give life and strength to them (Gose 1994: 131-134; see also Allen 2002[1988]). Thus, death and life are united through a single hydraulic cycle linking the production of water in the western land of the dead with the "germination and growth of maize in the east" (Gose 1994: 126; see also Gelles 2000: 87, 184n11). The dead travel underground (in Apurímac, to Mount Qoropuna), where fire and heat extracts the water that animated them during life; through underground waterways and streams, this water is expelled "back to the land of the living" (Gose 1994: 129-130). Through the mediation of plants (above all, maize - hence the symbolic importance of chicha), the vitality of sami is "[converted] into a source of life and growth" that in turn gives life and animation to people (Gose 1994: 130-134). Susana related the connection between life, death, and fertility when she said:

When we die, we enter the earth. All are there, bones and all. When we are born, there it is the same. We eat all the products from the same earth.

Although the mountain spirits are the source of this essential animating force, people must also do their part to sustain agro-pastoral production (see Gose 1994: 131); therefore, people irrigate, sow, weed, harvest - and feed the mountain spirits who control water (see Isbell 1978: 139, 151). While the mountain spirits ensure the continued fertility and abundance of the crops and herds by directing this animating energy (sami) through water to the fields and pastures, ritual offerings direct the sami inherent in food and alcohol back to the mountains and the ancestors from whence it was extracted (Allen 2002[1988]: 33). Thus, the offerings of t'inkas and despachos are not just the proper 
serving or payment required by the mountain spirits that indeed push them "towards a very specific agricultural function"; they are also the manner in which this essential energy stays in circulation by being directed back to the mountains.

As the previous discussion of gentiles indicates, however (see Chapter 2), the benevolence of the mountain spirits is not the only thing that is referenced by these ritual offerings and payments. According to Olivia Harris (1989), mining belongs to the same field of production as the raising of crops and livestock. The symbolically rich yet contradictory, and always powerful, realm of mountains leads to much ritual attention directed towards the "devil" who owns each mine. The "presiding deity" of a mine is known as Supay Muqui (devil) or Tio (uncle): "He owns the veins of mineral, and gives sometimes abundantly, sometimes sparingly, as well as on occasion killing those who work to extract the ore" (Harris 1989: 249). The Supay is "like the guardian and owner of the mineral, who appears to miners to ask them for offerings in exchange for rich minerals and leaving them to work in peace" (Salazar-Soler 2006: 131; my translation). These offerings or payments include coca, cigarettes, trago, and occasionally sacrifices (Salazar-Soler 2006: 131; Harris 1989: 249-251; see also Nash 1979). He is not the source or generator of the minerals (that is more the domain of the pachamama); rather, he knows the secret places where minerals "grow" like potatoes and he is able to transport them from one place to another (Salazar-Soler 2006: 134-137, 173; Harris 1989: 252). He is, however, associated with fecundity:

Some testimonies indicate that the Muqui consumes human feces and transforms them in his body into gold, which he will later defecate. For this reason when miners find a mineral-rich vein, they defecate to the side as an offering to the deity of the mine... (Salazar-Soler 2006: 136; my translation) 
The Supay is an ambiguous figure, sometimes generously leading miners to rich finds and other times, with "great hunger," causing sickness, accidents, and deaths; he is also renowned for his enormous phallus and "sexual appetite," which is one of the reasons why women are prohibited from entering mines (Salazar-Soler 2006: 137). He is described as a small, bearded, white man with red eyes, dressed in mining clothes made of gold, and able to change into animal forms such as a frog or black dog (Salazar-Soler 2006: 134). He is also associated with the gentiles, the ancient, condemned, people of a mythic pre-Incan era (Salazar-Soler 2006: 138-139).

Mines are also abodes of other powers, both "diabolical" and "celestial" (SalazarSoler 2006). These include the pachamama, whose "body" in effect is the mine, and other regionally distinct figures, such as those described by Salazar-Soler for Huancavelica: Juana Tintaya (the wife of the Muqui and the diabolical incarnation of the Virgen del Rosario), tayta Wamani (the "spirit" of the mountain who appears in human form as a tall, pallid-skinned patrón - associated with the condor, lightning, rain, and fertility), el Amaru (the two-headed snake, guardian of the mines and companion and messenger to the Wamani and Muqui, also associated with lighting, violent rains, hail, and ice), el Pishtaku (the extractor of runa fat existing on the margins of social norms as a figure of incest, drunkenness, thievery, and sickness), Qarqarya (figures of incestuous condemnation, often taking the form of llamas), and various Taytas ("fathers," saints and incarnations of Christ; intermediaries between people and God) and Virgenes (especially the Virgen del Rosario, invoked for protection and fertility, and associated with both the pachamama and Juana Tintaya) (Salazar-Soler 2006: 173-201). 
Although the Supay is of principal ritual interest to miners, any of these figures may be addressed for specific needs or during particular festivals (Salazar-Soler 2006: 173ff). Ritual offerings and sacrifices are necessary not just because the Supay is hungry and must be paid, but because reciprocal exchange is essential to fertility and productivity:

Like agricultural products, metals are considered by the miners as natural fruits, whereupon one must establish relations of reciprocity to assure an abundant harvest. (Salazar-Soler 2006: 173; my translation)

This supports the claim made by Harris that mining and agro-pastoral activities are of the same sort of production in Andean thought and practice (1989: 251):

The union between the primarily agricultural pachamama and the tio of the mines [e.g. the conjugal pairing of Supay and Juana Tintaya in Huancavelica] makes this explicit. Moreover, there are striking similarities between the rituals performed for fertility of the mines, and those for the pachamama and other guardians of the fertility of fields and flocks, such as the mountains. (Harris 1989: 251-252)

Just as the raising of crops and animals is a productive activity that sustains the community and the household, so is mining; just as agro-pastoral abundance and fertility require the feeding of hungry guardians and source powers, so too with mining. By extension, money ${ }^{34}$ itself is both an index and source of fertility (much like the cornbased chicha that is the concentrated embodiment of sami). Among the Laymi of Bolivia, money is considered along with livestock and crops as one of the "three forms of

\footnotetext{
${ }^{34}$ Not to misrepresent Harrris' argument and complicated exegesis, I will note here that she considers money a multivocal and at times contradictory symbol. Laymis consider it a product of the earth at the same time as of the state: "Money is generated by natural fertility, in the same way as all aspects of wealth and abundance, but at the same time it is created by the state, as is evident from the very appearance of coins and bank-notes [made in state mints]. It derives, then, both from nature and from the law, and since these two sources are antithetical to each other, money itself has a dual, ambivalent character" (Harris 1989: 255).
} 
abundance" (Harris 1989: 253); libations that are made to money "aim to ensure the fertility of the mines which not only produce money in the sense of minerals, but are also the source of markets, of urban consumers cut off from the process of food-production, and of monetary wealth" (Harris 1989: 254). In this setting, in which petty marketing is seen as benefiting the community as a whole,

money is said to 'give birth' (wawachi). People who make money to give birth in this way are thought to perform a valuable social service. Money, when it returns in the form of profit, is thus fertile in some way, though its fertility is realised not through the process of planting and maturation, but through exchange. (Harris 1989: 247-248)

Not all Andeans make such explicit connections between the fertility of money, crops, and flocks, all with a common source of abundance (Harris 1989: 254), as do the Laymi, who live in the shadow of Potosí. ${ }^{35}$ Yet other sources suggest that throughout the Andes, money is indeed a source of fertility that must be circulated through exchange and sacrifice by the same governing logic as agro-pastoral production, for the benefit of not just individuals but the entire community (see Seligmann 2004: 84; cf. Zevallos et al. 2004). For example, in the Cuzqueño markets studied by Linda Seligmann (2004), festivals for the market's patron saint are important, along with offerings made to personal market stall guardians (saints, virgens, ekekos), compadrazgo networks, and reciprocity in general. Similarly, Cecilie Ødegaard (2008) observes that offerings to God, the mountain spirits, and the pachamama are important for informal marketers in

\footnotetext{
${ }^{35}$ Potosí is one of the richest and most famous silver mines of the Spanish colonies (Harris 1989: 235; Klarén 2000: 43). It has been continually mined for over five hundred years and was a major site for the onorous burden of Indian tribute labour under the Spaniards (Harris 1989: 252; Klarén 2000: 67; Spalding 1984: 129, 164-165). It is notable that the productivity and profitability of Potosí was closely tied to the mercury mines of Huancavelica; from the 1570 s onwards, Huancavelican mercury was used to extract the silver (Klarén 2000: 44, 67; Spalding 1984: 164).
} 
Arequipa to progress and ensure success; especially powerful petitions can be made through a pilgrimage to the Virgin of Copacabana. Together they indicate that, as in the chacra (field), offerings, sacrifices, and payments made to divine sources of fertility, abundance, and productivity - as well as reciprocal work and favours among producers in general - are necessary to ensure the fertility and well-being of the productive zone of the marketplace and those who labour in it.

Like many Andean communities, both rural and urban, different sections of Cuzqueño markets have a patron saint that is publicly celebrated with an annual fiesta (Seligmann 2004: 162; see also Lazar 2008: 144-155). A series of fiestas lasting four days to two weeks, complete with a procession of the saint's statue accompanied by dancers, musicians, and the provision of food and drink, honours the patron saint of each market section (Seligmann 2004: 162). These market fiestas are notable in the unusually high number of women who serve as sponsors, who form the overwhelming majority of petty marketers in Peru (Seligmann 2004: 169; see also Babb 1989; Buechler \& Buechler 1996). Vendors, wholesalers, and other players in the marketplace may also participate in fiestas for patron saints of their larger urban communities (Seligmann 2004: 162); if they maintain ties to their rural natal communities, they may sponsor these fiestas there as well (Seligmann 2004: 162; Paerregaard 1997: 216-217). For example, Mamacha Asunta (Our Lady of the Assumption) is the patron saint of potato, onion, and fruit sections in Cuzqueño markets (Seligmann 2004: 165, 168, 174). Starting August 15, each section has a day to lavishly dress the statue of Mamacha, followed by a mass, procession, and fiesta (Seligmann 2004: 169-174). The patron saint of Cuzqueño artisans and contraband marketers is the Virgin of Almudena, celebrated on September 8 with a similar, but larger 
and more expensive, fiesta (Seligmann 2004: 176). Likewise, Florence Babb makes note of the fiesta honouring the Virgin of Fatima (May 13), patron saint of Mercado Central in Huaraz, Peru (1989: 1, 71), and Hans and Judith Buechler identify July 15 as the fiesta for all markets in La Paz, Bolivia (1996: 144, 165).

As in other Andean fiestas, the mayordomos, or principal sponsors, incur great expense to pay for food and drink for hundreds of participants (Seligmann 2004: 165). Lesser sponsors provide "clothing for saint images, music, and costumes" (Seligmann 2004: 165). The cargo office of the mayordomo, however, is considered particularly burdensome and honourable, and requires not only money, but also the aid and assistance of family and friends (Seligmann 2004: 165). Thus fiesta sponsorship is in one sense about one's ability to access these networks and call in favours. Like the host of an agricultural work party, the fiesta sponsor's ability to provide food and drink for participants demonstrates his (or her) superior socio-economic status and ability to access and direct labour and exchange networks.

Just as importantly, as in the countryside, the overprovisioning of food and oversaturation of alcohol during market fiestas are necessary to ensure the fertility and productivity of the marketplace:

The great circulatory system must be nourished fully and intensely so that Mamacha and therefore the market women who sell and the customers who buy goods will be able to provide. (Seligmann 2004: 173)

Like the minerals to be minted into money in the mining sector, profits in the marketplace are equated with fertility, which itself originates from divine powers that must in turn be fed (see Seligmann 2004: 171, 173; Ødegaard 2008: 255-262). While social connections, 
personal endowments, and economic acumen enable both women and men to enter the market, and while "faith" helps petty marketers (and indeed, many urban migrants) deal with the hardships of life (see Seligmann 2004: 165, 183-184, 192), they are not enough to guarantee prosperity and fertility in the marketplace. As in agro-pastoral production and mining, offerings must also be made to the divine powers who oversee the prosperity of the productive zone and the well-being of those who labour in it.

According to Seligmann, market vendors may also have a self-designated patron for their own market stall: a saint, virgin, incarnation of Christ, or other deity considered their "protector" in "time of need" (Seligmann 2004: 162; see also Ødegaard 2008: 256). Regular ritual offerings may be made to a saint or other divine figure after receiving exceptional good fortune (Seligmann 2004: 164-167; see also Ødegaard 2008: 256). Another divine figure that marketers look to for luck and prosperity is the ekeko, the "god of plenty"36 (Buechler \& Buechler 1996: 229). In La Paz, Bolivia (where the ekeko is especially associated with artisans and petty producers), the week of January 24 celebrates him with the fiesta of Alasitas (Buechler \& Buechler 1996: 229). According to Seligmann, market women and small store owners in Cuzco often have a ceramic ekeko in their possession, represented as an itinerant male marketer (2004: 46). Offerings of paper money, cigarettes, and coca are made to the ekeko to ensure economic success (Seligmann 2004: 46). However, the ceramic figure must be stolen or given as a gift to be effective: "Here, as in so many other instances in the informal economy, the appropriate activation and nurturing of social relations and generosity are critical to success in buying and selling commodities" (Seligmann 2004: 53).

\footnotetext{
${ }^{36}$ The ekeko may be characteristic of particular regions; Susana Bautista was not aware of the ekeko although they are easy enough to find in Lima, and she and her son regarded it with interest when a vendor came to el Mercado del Unión one day selling them.
} 
Indeed, the form and content of these offerings and market fiestas resemble agropastoral rituals in the countryside. Moreover, the persuasive force of reciprocal exchange, particularly connected to feeding, is likewise integral to the success of petty marketing, accessing and selling goods, client-patron relationships, community solidarity, and social networking and relationships in general. This claim is of no small consequence to a consideration of urban migration, as a large number of migrants from the countryside end up selling uncooked and prepared foods and consumer goods requiring little capital investment on the streets of cities such as Lima.

For example, Susana has a small cevichería in the Mercado del Unión in her neighbourhood of Bayovar, San Juan de Lurigancho, Lima. She sells the immensely popular "national" dish of ceviche at S/. $1.50-3.00$ a plate to workers and passers-by for lunch in the poor, informal market outside of the "official" market building. This is a coastal dish consisting of raw fish of any sort (or shellfish such as crab or mussels) "cooked" in lime juice and seasoned with salt, ají (hot pepper), and red onion (sometimes garlic as well), accompanied by boiled camote (sweet potato), choclo (boiled, fresh, sweet corn), cancha de maíz (dried, toasted corn), lettuce, and sometimes garnished with seaweed. More elaborate plates may include boiled or fried yucca or chicharrón de pescado (deep-fried pieces of fish or octopus). It is often served with chilcano (a clearbroth soup made from boiling the smallest, cheapest fish) or chicha morada (a sweet drink made from blue corn with lime juice). It is one of the most popular foods to eat on the street for lunch (as well as in upscale restaurants), as it is cool and refreshing, relatively cheap to make (and thus to buy), and with the exception of the preparation of 
the accompaniments that can be completed beforehand (camote, choclo, chilcano, chicharrón), has the advantage of not needing to be cooked over a natural-gas burner.

Like Teofilia with her fried-egg stall in Paucará's feria, Susana is helped by her youngest daughter of eleven on the weekends and her "daughter-in-law" during the week after her second son's baby was born. Her daughter was obviously being socialized into the female role of food preparation and provisioning at the same time as learning a marketable skill (all her other children were working on the street by the time they were seven). Her son's girlfriend (actually not her "daughter-in-law"; Susana would probably object, at least at the time, to having her identified as such) was "working," somewhat to her own objection, in the cevichería because there was the strong feeling that she must do something to contribute to the household she had begrudgingly become a member of. Difficult as the "daughter-in-law's" situation may have been, to some extent it adhered to the Andean norm of virilocality; at the very least she did not have to rise at dawn in servitude to toast barley and prepare breakfast (see Weismantel 1989: 94). Here the inverse logic of feeding surfaces: while workers can expect to be fed by the proprietor, those who eat (particularly subservient non-kin) are expected to work. (Susana was very indulgent of my sporadic forays into the kitchen when I stayed in her home, although I was sure to bring in cooked foods whenever appropriate and leave her with some money before returning to the countryside).

I strongly suspect that like the informal marketers described by Seligmann (2004) and Ødegaard (2008), Susana drew upon her relationships with other market vendors to secure a favorable (or free) rate for her ingredients, probably providing plates of food in return. Susana herself did not have money to eat lunch in the marketplace; her youngest 
son always brought her a dish that was cooked by her middle daughter at home.

Following Sheldon Annis (1987), I would even venture to say that her cevichería is not aimed at accumulating surplus capital, but rather the maintenance of the household. The income that Susana earns from her cevicheria is minimal, basically only enough to cover costs for the following day and buy ingredients to make soup for supper that night. (She also covertly saves a little whenever she can for her own expenses). Nevertheless, it would put considerable strain on the household economy were she not to earn this much. ${ }^{37}$

The low return and instability of petty marketing thus tends to reinforce the importance of non-monetary exchange such as informal barter and work reciprocity. If Susana did not benefit from reciprocal exchange in the marketplace on a daily basis, she certainly did on one special occasion. For her second son's third "anniversary" as a professional harpist, ${ }^{38}$ she and her husband organized a neighbourhood concert featuring Alfonoso's folklórico band and various other huayno musical artists from their corner of Lima. Although this was a for-profit event, Susana used her market connections to obtain 120 chickens and the other ingredients needed to prepare plates of fried chicken with boiled potatoes and salad that she and her daughters sold to the crowd that attended. (Alfonso also made a good profit by contracting someone to sell 60 cases of beer). The preparations began early in the day so that some plates would be ready for lunch, when

\footnotetext{
${ }^{37}$ It is notable that, like so many other livelihood occupations of poor urban migrants, Susana's small cevichería does not enable the family to "progress" in an economic sense. Fully proletarianized (e.g. with livelihoods based on wage labour), the Bautistas see as their only option to better educate their children and invest in a business with greater return. Don Pedro's real dream is to own an abarrotes (dry-goods) store like his older brother. Going into business together is not an option, however. His brother, the eldest of Mamaku's children, left Paucará at a young age to make his way in the city; he has not maintained close ties with his siblings and is seen as concerned with the well-being of only himself and his own family. ${ }^{38}$ Such an event recalls the sponsorship of a public fiesta that may be made by harpists in the countryside as a "promesa" to sirenas in exchange for success and prosperity (Gose, personal communication; see also Tomoeda 2006 on the blessing of musical instruments in waterfalls where sirenas are said to live).
} 
Susana's children brought "complimentary" plates to the vendors in el Mercado del Unión who had helped them by giving chickens and potatoes of their voluntad. No doubt this small exchange is part of a wider relationship that Susana has with each vendor that stretches out over time (cf. Sutton 2001).

This is an example of how vendors who "sabe invitar" ("know how to share"; Harris 1989: 246) utilize reciprocal exchanges and feeding to forge relationships in the marketplace, strengthen ties of mutual benefit, and create a reputation for generousity and success. Marketers often give caseros (regular customers) una llapa, "a little extra" as a gift and incentive to return (Seligmann 2004: 49-50; Babb 1989: 111). Other opportunities for informal gifts and exchanges are numerous. For example, a young woman trying to establish herself in the marketplace may peel and chop vegetables for a more established marketer, who will then lend her capital to buy some produce to sell herself (Seligmann 2004: 33-40). Alternatively, a market vendor may obtain potatoes at a reduced price from a supplier in the morning; the same supplier will come to her cookedfood stall for a free lunch in the afternoon (Seligmann 2004: 42-44). Sometimes market women exchange work for like work. For example, if a woman needs to leave her stall before she has sold all her day's goods (e.g. due to a sick child), she may ask a fellow marketer who she trusts to sell the remainder of her products for her (Seligmann 2004: 42-43). This way, she will not lose her day's investment; her fellow marketer knows that she can call upon her for a similar favour in the future.

Such exchanges evoke the fecundity of debt observed by Harris: in Northern Potosí, debts are considered fertilizing like manure - investing, so to say, in prospective productivity with the expectation of reciprocal generousity at some time the future 
(Harris 1989: 248). Much like reciprocal drinking structures so important to masculine work and sociality, "gifts," "discounts," and "bonuses" among petty marketers illustrate how feeding can be used to push people towards a desired goal in an urban setting.

Such strategies may also tap into more formalized relationships of exchange, such as compadrazgo networks. For example, a wholesaler or marketer may be guaranteed access to produce from his (or her) campesino compadre; the campesino in turn may have a place to stay when he (or she) comes to the city to sell produce (see Seligmann 2004: 80-81). The flow of people and agricultural products between rural and urban areas indeed has a long history in the Andes (see Gose 1994: 192; Weismantel 1999: 149; also Collins 1988; Harris 1989; Skar 1994). It is particularly evident through compadrazgo networks, in which regional products often are exchanged - for example, cash, coca, and shamanism in exchange for wool, potatoes, and textiles (Allen 2002[1988]: 69). Through compadrazgo ties, individuals gain access to "business partners, loan services, and agricultural labor" (Weismantel 1988: 82); compadrazgo relationships may even be forged with the sponsorship of new market stalls (Babb 1989: 74).

Just as the reality of Andean people's lives illustrate that the country and city are not totally separate realms because of the constant flows of people, consumables, and practices that connect them (see Paerregaard 1997), so too are the domains of cuisine, agro-pastoralism, wage labour, petty marketing, and ritual symbolically and practically connected by the idiom of feeding. "Feeding" itself condenses many significations, goals, and movements in the lives of Andean people. At times it is an exchange (e.g. of present or future work or favours in return for food; as a gift that incurs prestige; by moral obligation as a community member and competent, decent social actor); at other times the 
movement generated by feeding is more like a circulation (e.g. of vitality and life between the mountain spirits and people; of social solidarity and profit among market vendors). Sometimes others are fed as a payment (e.g. hungry diablos in the hope of ending sickness; the Supay Muqui with the aim of obtaining mineral wealth; market suppliers in order to guarantee preferential rates the following day); at other times the feeding is a sacrifice (e.g. in deference towards mountain spirits, the pachamama, and Supay Muqui). None of these aspects of feeding are mutually exclusive; indeed, part of the persuasive force comes from the condensation, multivocality, and reiteration of the symbolizations of feeding in practice.

Two examples can be considered here that highlight these different characteristics of feeding: as exchange, circulation, payment, and sacrifice. First let us consider agropastoral rituals. The ritual plates of consumables or "feedings" presented to the mountain spirits on ritual mesas ${ }^{39}$ are called at once "payments" and "offerings." Sometimes mountain spirits (and a host of other individualized and non-individualized forces, such as el Supay Muqui and diablos) must be "paid" to assuage their hunger. At other times, they must receive sacrifices to ensure the fertility, well-being, and prosperity of the crops, herds, mines, household, and community. In one sense, these sacrifices are efficacious because they keep the essential life-energy or sami in circulation, with the animating essence moving from the mountain spirits to plants to people. In another sense, payments and offerings are effective because they are the terms of exchange for reciprocal obligations: "each must be fed to do his part," and if campesinos feed the mountain

\footnotetext{
39 "The specific Spanish word for such rituals is either mesa (table) or misa (Mass). They get mixed up in part because Aymara [as well as Quechua] does not distinguish between the $e$ and $i$ sounds... But of course there is more going on, as the misa/mesa is an offering to the deities in much the same way as the Catholic Mass is. The 'table' translation also underlines the fact that what is being offered to the deities is food" (Lazar 2008: 151).
} 
spirits, the mountain spirits will feed them in turn by providing them with abundant crops and herds. Likewise, if those who labour in the market feed Mamacha, she will provide them with prosperity and abundance in the marketplace.

As this indicates, just as divine powers are fed to "advance" production in the countryside, so too are people fed to progress the fertility of social relations and the market in the city. Market vendors who give a plate of food to produce suppliers or "little extra" to regular customers participate in an exchange in which food is a "return favor" or "gift" to lend stability to their access to goods and prosperity in selling them by creating a reputation for generosity and endearment. Such feeding may also be thought of as a payment in setting the terms of barter-like exchange: a plate of food at lunch for the reduced price paid for produce in the morning. But from another perspective it can be a sacrifice, as the llapa provided by the same supplier comes out of potential profit; such "invitation" is made in the implied hope of equal or greater return in the future (e.g. in continued transactions). Such transactions do not just keep goods and money in circulation; they also keep "social capital" flowing among producers, suppliers, vendors, and customers. ${ }^{40}$ That is, the feeding of others contributes to goodwill, sociability, and the desire and capacity to work together for mutual benefit - all the more important in the informal economy, in which so much depends on one's connection and relation to others. This can also be seen in reciprocal drinking sessions which are particularly important for men to forge and maintain connections to business partners, mentors, and employers in the informal economy.

\footnotetext{
${ }^{40}$ I use this phrase with caution, for Paucareños themselves do not articulate their motivations or reasoning in this way. However, it is more or less apparent that an important outcome of such feeding in practice is the creation of a generous, endearing, and morally decent social identity that influences how one is perceived by others and what sort of relationship one is able to have with them as a result. The myriad of informal exchanges and gifts of food "keep the gears oiled," so to say.
} 
In the first set of examples, it is fairly obvious that feeding is a force of production: it is something which pushes life-giving powers towards the growth and abundance of crops, herds, mines, and even markets. Like the ritual competition between yaku alcaldes (water mayors) that is said to "advance" irrigation observed by Paul Gelles (2000: 89), such opposition and complementarity of reciprocal obligations can be said to "advance" production. Mountain spirits and runa have distinct, yet complementary, desires and obligations: people must feed the mountain spirits in order to be fed in turn. When they each "do their part," all benefit at the same time that individual goals are realized. Similarly, feeding compadres, business associates, and clients "advances" social relations and opportunities that are integral to prosperity in the informal economy, in which most urban migrants (indeed, a very large number of Peruvians) make a living. Like the ritual plates offered to divine powers, plates of cuy or ceviche push the recipient towards a desired goal. However, in this case the outcome is not as clearly articulated; one hopes that one's compadre will be honourable and generous in offering one's child an opportunity for education or employment, but it is by no means guaranteed. People can neglect or fail to reciprocate in the desired manner, which seems to be an inherent possibility of informal exchange or generalized reciprocity. The generousity and hospitality of others can even be abused towards no productive end, as Alfonso's padrino did one day when he arrived unexpectedly at the house drunk. Social norms of hospitality and decency obligated Alfonso to spend the rest of the afternoon unenthusiastically drinking with this man until he passed out in his chair.

Nevertheless, without creating a context of obligation for reciprocal exchange (often but not exclusively crystallized in an act of feeding), one cannot hope to advance 
very much. Marketers who "no sabe invitar" are not going to be regarded in a favourable light; customers will seek out more generous vendors with whom they can have a relationship of mutual benefit. This is perhaps a reason why Susana and her daughters rarely patronize the store of Pedro's elder brother, who has an "official," prime location in the very same market in which Susana has her stall. It could be the case that in some way they perceive such transactions as advancing little in their relationships or well-being (a disturbing situation for family solidarity indeed). More evident, however, was the fact that they did not like one another very much, as summed up in the family's assessment that the uncle did not share with them or offer them assistance despite his close proximity and relative wealth.

Therefore, I would suggest that reciprocal obligations (in a context of opposition and complementarity) are more persuasive or powerful in these imminently social (and somewhat ambiguous) ways than any "economic" rationalizations that may inform exchanges within and without the marketplace. That is to say, people do not generally feed someone just because they expect a specific "return," even though a certain outcome may be hoped for (see also Lazar 2008: 153). Rather, food exchanges take place in a wider context of sociality and individual relationships, at the same time that they may be pertinent to particular goals or strategies. Sutton astutely observes this non-instrumental potentiality in his discussion of food exchanges:

Exchange should not simply be exoticized as an attempt to increase one's "capital," - material, symbolic, or other... Exchange is about social relations, yes, but social relations are about identity construction as much as they are about some calculus of future gain/material obligation. In other words, it can be seen as a human attempt to create social relations for their own sake, not just as a pay-out in the present in order to claim benefit in the future... The value of hospitality and 
generosity, then, seems to be embedded in the total system of values, and cannot be abstracted out in terms of some calculation of specific reward. (2001: 50)

Informal exchanges and gifts through feeding can push recipients towards desired goals, but such desires are not necessarily the primary motivation or part of their "rationalization." Relatives, compadres, business associates, and acquaintances may have other ends in mind, such as being a competent and decent social actor, upholding a reputation for hospitality and generosity that will put them in a favourable light, and creating a certain kind of relationship through the subtle interplay of the movements and meanings of feeding (e.g. one characterized as hierarchical or equal; one that the recipient will likely want to continue or abandon).

As this discussion hopefully indicates, by claiming that feeding is a force of production and advancement, my intention is not to equate the two while at the same time opposing "production" in the countryside with "advancement" in the city. In their distinctly local or Andean understandings, production and advancement are similar in some ways and distinct in others, while at the same time complementary and co-existent. They do not have linear or dualistic narratives, but rather cohere around some areas and bleed into others. Production and advancement are commensurable insofar that they are both in some way about fertility and well-being: the fertility of crops and herds, mines and the marketplace, social relations and exchanges; the well-being of households and communities in terms of health and contentment, the ability to get things done, and relating to wider social spaces (see Chapter 2). Thus feeding "advances" agro-pastoral and market-based production as modes of livelihood in strategic ways. 
Yet the "feeding" of social relationships is also about "advancement" in that other sense akin to, but distinct from, development and modernization: progreso or progress, which leans more towards notions of advancement and moving forwards (or onwards) in a general sense than a project of "development" or "modernization." When informants told me of their hopes and dreams for their lives and their families, they never spoke of desarollo (development) or, worse yet, ser moderno (to be modern), but either specific goals (a stable livelihood, education, a business, a house) or progreso in a general sense. The semantic use of progress held the impression of movement onwards simply because that is the nature of movement, rather than movement towards a pre-determined end (i.e. a developmental utopia), such as in el año progresa (the year progresses) or progresa la familia (the family is progressing [advancing, bettering]). In this sense, feeding can also push social actors towards hoped-for (yet indeterminate) outcomes; advance one's relationship over time (e.g. from guest to compadre); and lead to social dynamism and movement generally (for example, in keeping market relations amiable and stable), as feeding and exchanges of food are so integral to Andean society in so many ways. But as noted above, this "advancement" should not be taken as a kind of "social production" in an economic sense.

In considering the contexts of feeding, it is therefore not particularly useful to make a distinction between the country and the city, at the same time as it is problematic to contrast feeding that is "sacred" and with that which is "profane." People can hope to advance social relations in the countryside by feeding (e.g. Frederico's strategic claims on me in the hopes of accessing a loan) just as they can hope to advance fertility and production through feeding in the city (e.g. offerings made to the patron saints of 
Cuzqueño markets). On one hand, it is apparent that some plates are indeed offered to divine powers with the underlying cosmological notion of the circulation of an animating life-force, and other plates are offered to people with more specifically social implications (for example, of making a reputation or a claim on another). Nevertheless, what these different contexts of feeding have in common is that plates of food are offered to social actors (e.g. figures that are bound to social norms in relation to other members of the community), and that such giving and receiving creates a social context (e.g. of obligation and reciprocity). Feeding in the field, the mine, the market, and the home continues to be the practical "logical consequence" of the conception of the pump-like movements of obligation and reciprocity in the Andes in which life-giving energies are circulated (see Allen 2002[1988]: 73).

As this suggests, practices of feeding are thus always emplaced. They occur in specific contexts in relation to specific social actors, which in Casey's (1996) terms, means that a plate of food is offered in one particular place and no other. Not only do both the giver and receiver have to be somewhere, this "somewhere" is somewhere specific and not another place: Verónica's kitchen, Rosa and Manuel's field, Susana's market stall, the Bautista's rooftop patio. Where the feeding occurs is almost as important as who is involved, as distinct places will set different terms of exchange (e.g. food for labour in a mink' $a$ work party in a field; a meal for money in a restaurant; a notion of gratitude and indebtedness upon being offered a meal in a relative's home).

Places furthermore, in Casey's terms, "hold" particular configurations of people, objects, intentions, feelings, and memories. Thus for me to accept a plate of food in Veronica's kitchen has meanings and connotations distinct from sharing a family feast 
with the Bautistas for Fiestas Patrias (Independence Day) on their rooftop, which was made possible with money that I gave Susana for the occasion. Moreover, being fed by either of these two households was completely different in significance and meaning at the beginning of my fieldwork than at the end, when bonds of endearment and solidarity had been established, and when we had many memories of previous meals shared together from which to form reference points.

As this indicates, a significant factor in the contextualization of feeding, which has only been alluded to so far, is memory. As a social occasion, feeding includes not just people themselves, but how they relate to one another: what they know (or do not know) about others present (e.g. if they are family members or strangers; what their intentions are), what they think or feel about them (e.g. if are they grateful and generous or selfish and ungracious), how they evaluate them in relation to themselves or others (e.g. as social equal, superior, or inferior; who is to be served first or last; who is obligated to reciprocate or not). Following Sutton (2001), there are a number of characteristics of the role of memory in feeding that can be usefully highlighted as particularly salient to the practices and thought surrounding feeding in the Andes.

First and most obviously, the role of memory in feeding is retrospective. It involves a remembrance, a "looking back," and a reference to the past (Sutton 2001). One can remember other meals offered to or shared with those present, where it was, what foods were eaten, how they were offered and received, and what (if anything) could be thought of as resulting from the meal. These memories (and evaluations) can be drawn upon to set the context for any other meal shared with an individual. The memory of feeding therefore is also cumulative: memories of food events and the people involved 
are collected and re-contextualized in relation to each other over time (see Sutton 2001: Chapter 2). Thus one can create a reputation through food (of having a particular taste, being a gifted cook, or being generous or miserly), and one's character can be evaluated by others in reference to food events (for example, one achieves a certain degree of respect and prestige upon generously sponsoring the Fiesta de Mama Cocharcas).

The retrospective and cumulative characteristics of food memories often work together. Thus Verónica and Mamaku remembered that I did not like caldo de panchito, yet they were determined that I should eat it all the same; although I knew to refuse the caldo would tarnish my reputation of gratefully accepting anything they fed me, I could not enjoy it as they could, with their years of remembrance of rare sheep parts that were savored as a treat and the comforting taste of the familiar. On another occasion, Rosa and Manuel knew that I could not cram so much into my stomach as the average Andean and were not offended when I could not finish the entire cuy they cooked for me as their son's madrina; the more important thing to them was that the meal formalized and sealed the connection that I have to them and their family.

As my compadres, Rosa and Manuel can now look forward to future meals they expect to offer me as a fictive kin member and not just a strange guest, and the presents and treats I will bring their family and assistance I will offer their son in return. Feeding is thus also prospective, looking forward to food events that will in turn be remembered in the future, such as expected meals or reciprocal exchanges (see Sutton 2001: 19). As should be expected, the prospective characteristic of feeding plays a remarkably significant role in exchanges of food in the Andes, where more often than not, a beneficial outcome of some sort is expected sometime in the future (even though it may 
be unarticulated). But feeding can also be prospective in the sense discussed by Sutton, in which people enthusiastically anticipate special meals or dishes that one can expect to eat at certain times of the year, such as the delicious pachamanca prepared especially at harvest time, in which fresh produce and sumptuous meats are cooked in dirt ovens in the field (Gutarra \& Valderrama 2001); during a stage of the life-cycle, for example, the funeral feast at the pichja that Verónica evidently planned for by bringing a spoon and take-away containers; or when one is far away from the familiar "taste of home," such as the avocadoes, chirimoya, charqui, huayro potatoes, and cheese enjoyed by the Bautista family that Yhosef brought back from Paucará (Sutton 2001: 28-31, Chapter 3; Sutton 2005).

Thus feeding is patterned - that is, meals are structured over time stretching from a day to a week, year, or lifetime (Sutton 2001: 7-8, Chapter 4). Sutton builds on the structuralist work of Mary Douglas to show that "people use one meal to recall another" through the repetition of meals and the narratives created by them (Sutton 2001: 103). While the "basic similarity of meal structure means that one meal calls others to mind," the "normal routine" can also be altered "in patterned ways" (Sutton 2001: 108; emphasis in original). For example, Susana had a repertoire of hot drinks that she made for breakfast in Lima, including quaker (watery oatmeal with condensed milk, cinnamon, cloves, and sugar), ponche de maca or habas (dried and powdered maca root or fava beans with condensed milk and sugar), and quinua (soupy quinua thickened with apple purée, with cinnamon and sugar). Often these fortified drinks were accompanied by pancitos (little breads), sometimes with butter, jam, or cheese. Moreover, in her house as well as kitchens throughout the countryside, there are many variations on the 
paradigmatic sopa that is at the "heart" of Andean cuisine (Mendoza \& Campos 2004: 28): a salted hot-water broth based on potatoes and/or chuño, olluco, quinua, morrón, rice, or noodles; with bits of vegetables such as carrots, peas, green onion, celery, squash, or nabos; seasoned with wild herbs, packaged spices, and/or cooking oil (see Weismantel 1988 for a more detailed discussion).

Different meals thus can be related and evaluated next to one another in the context of an established, customary patterning of meals and dishes. For example, breakfast in the country is usually toasted barley café, hot soup, and other hearty dishes such as roasted potatoes and boiled fava beans; a much-desired but rare treat would be bread and sweetened café with evaporated milk. The fiambre at lunchtime, if it is eaten at all, is more often than not boiled chuño; supper is soup again. Sundays may include something special, such as chicharrón, fried cachanga, fruit, or iced yogurt in the marketplace. Special seasonal meals include caldo de mote for the Fiesta de Santiago, puchero at Carnival, and pachamanca during harvest. Some of these dishes are appropriate only to certain times of year: children look forward to hot chocolate and panetón at Christmas, but to eat this at another time of year would be strange.

To return to the topic of the role of memory in emplacement, place is therefore important to contexts of feeding, but for the purposes of this discussion, not in highlighting an opposition between the countryside and the city. Admittedly, in terms of food selection and preparation (as well as the knowledge of production and technique), there are significant discontinuities (as well as notable continuities) in contrasting the two. Yet in terms of the practices, movements, and meanings surrounding feeding in urban and rural settings, there is remarkable continuity and similarity, at least among 
urban migrants - that is, those bringing "lo andino" into the city on a permanent, largescale basis (see Zoomers \& Salman 2003). What is more significant regarding place in contexts of feeding is the synesthetic, embodied memories (Sutton 2001) of food and feeding that are "held" in the places known to Andeans: their fields, homes, and markets. "Place" is a primary element of the context of feeding (which sets the stage and tone for the food event), as well as something that is recalled in the remembrance of food experiences. Furthermore, there is an ongoing compulsion to feed Places and create social networks; over time, there is an accumulation and remembrance of the persuasive force of such emplaced feeding. 
Plate 5.1

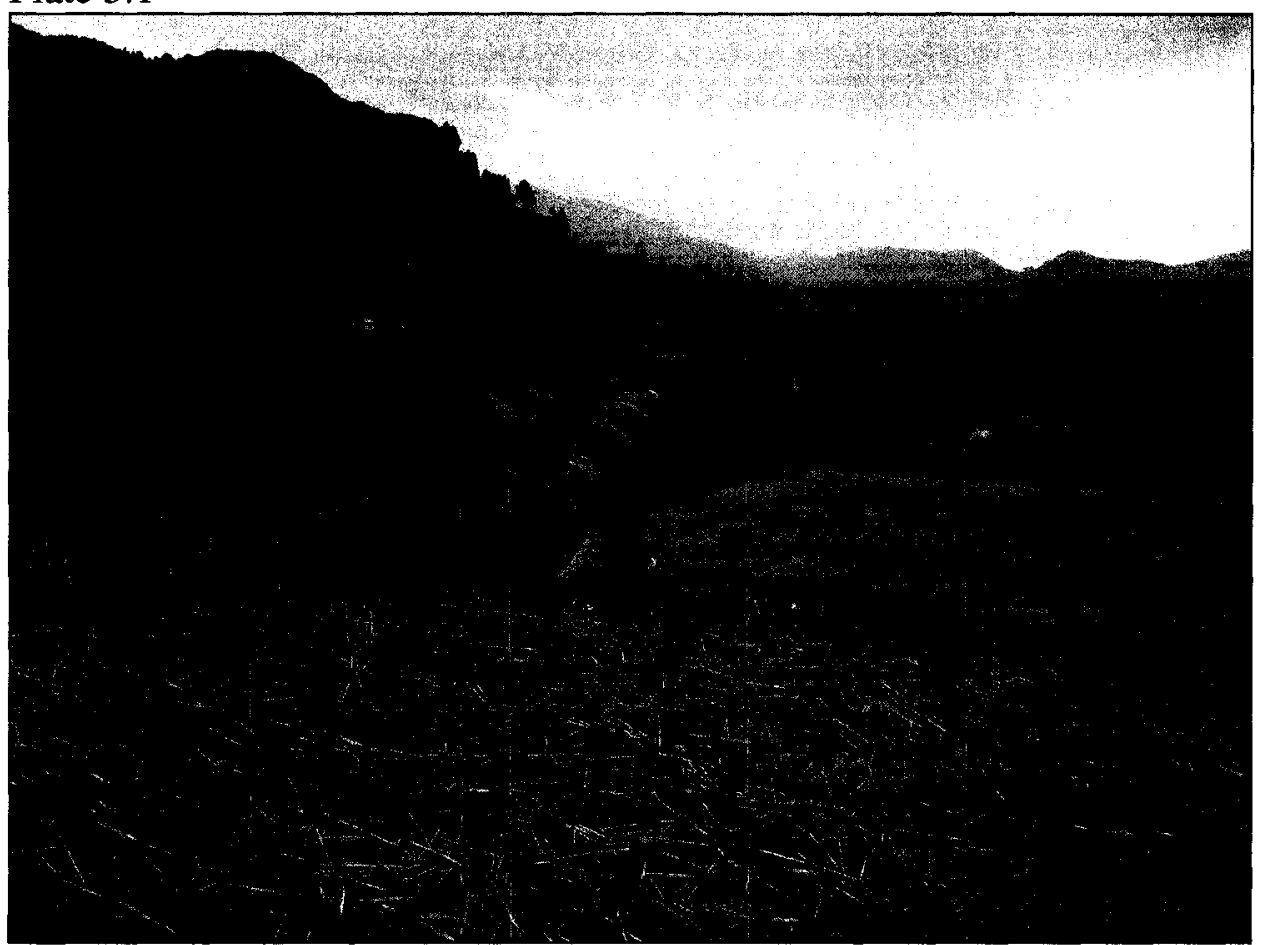

Jeremiah uses a foot plow to turn over soil for a small field where he will grow fava beans. Manuel described this as "abriendo la sangre," opening the blood. Paucará, September 222007.

Plate 5.2

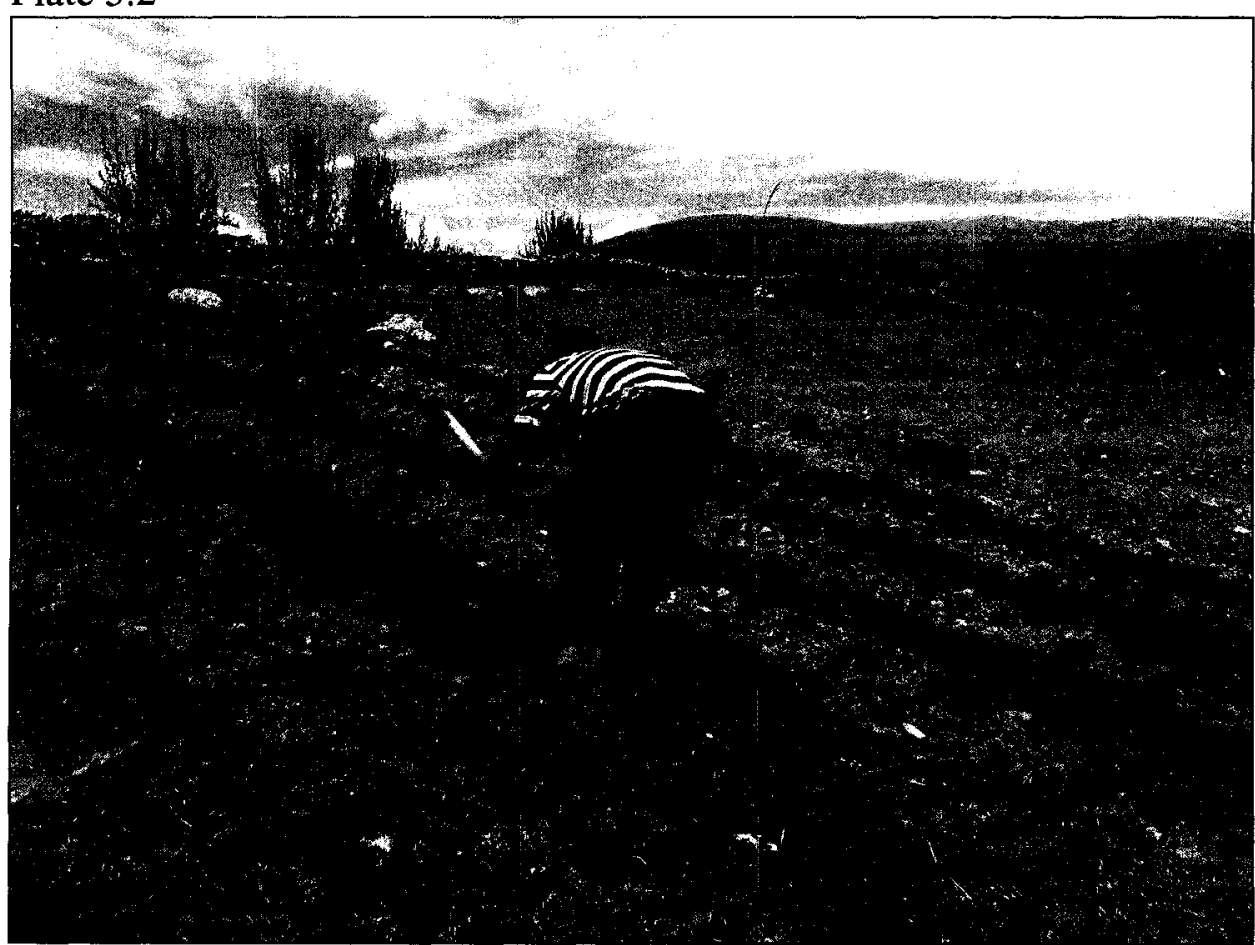

Manuel makes rows using a hand pick in his potato field. Paucará, November 262007. 
Plate 5.3

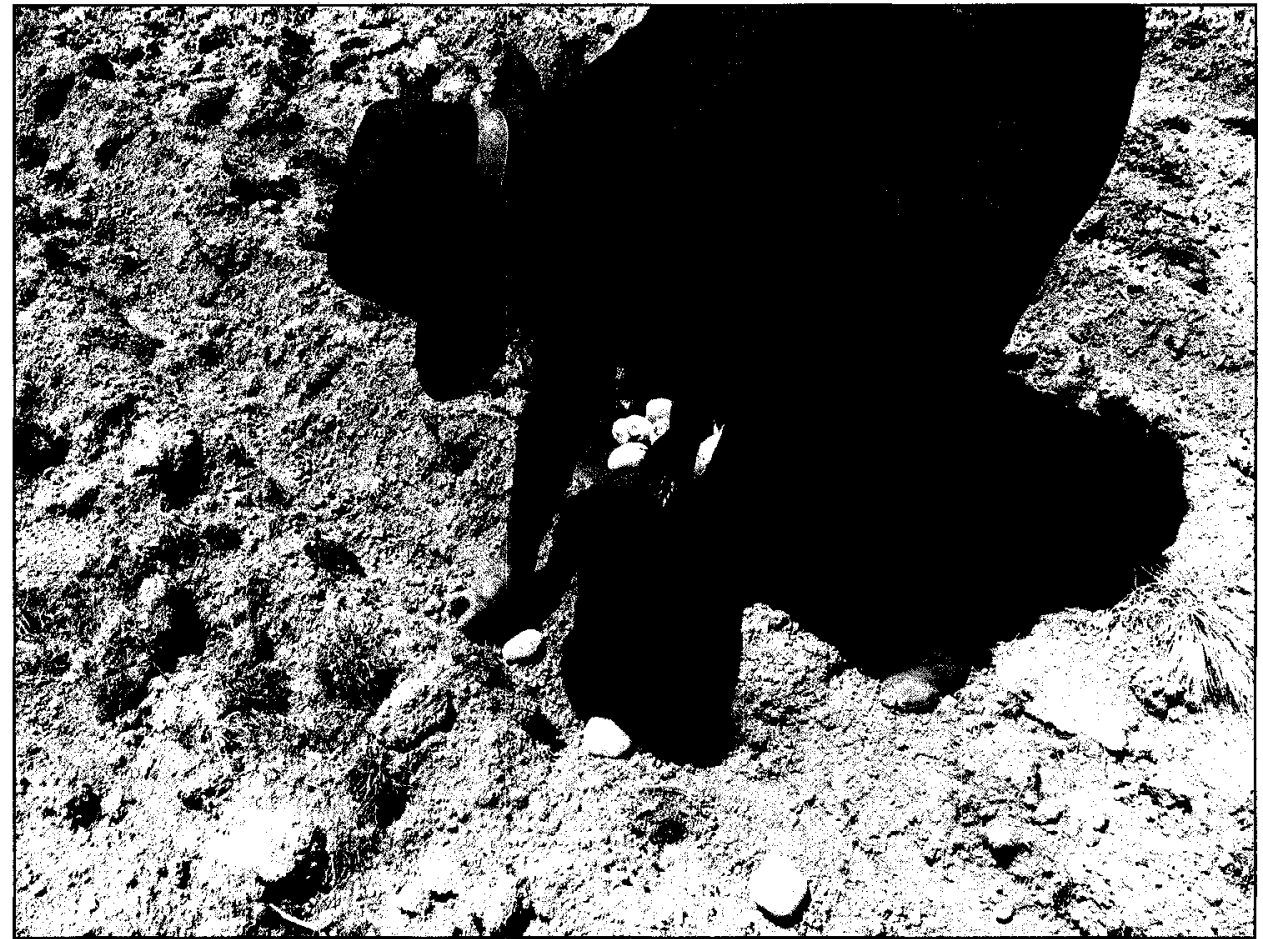

Rosa plants seed potatoes. Paucará, November 282007.

Plate 5.4

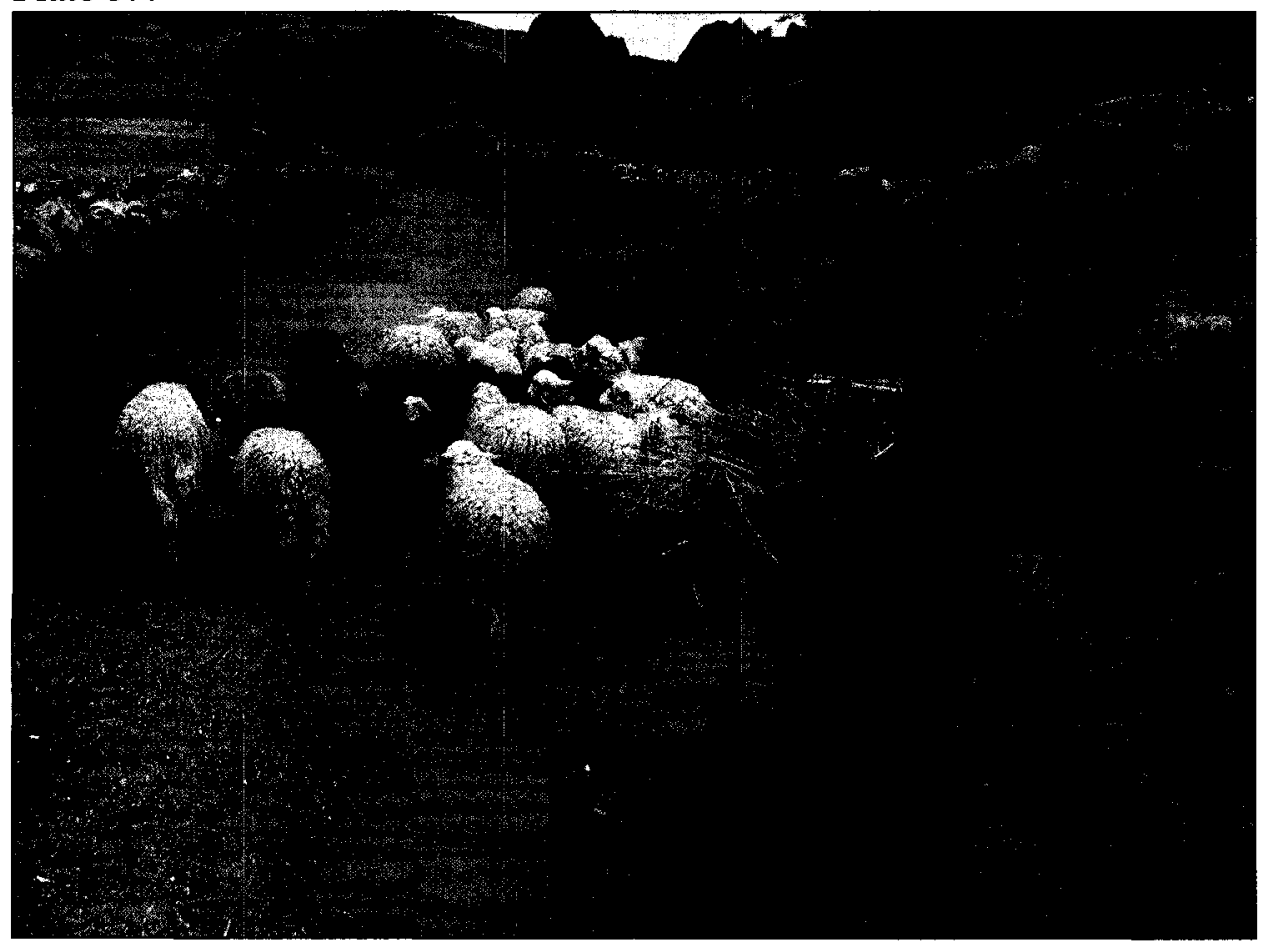

Mamaku brings her sheep back from the pasture, with ichu grass for her cuyes in her manta. Paucará, September 132007. 
Plate 5.5

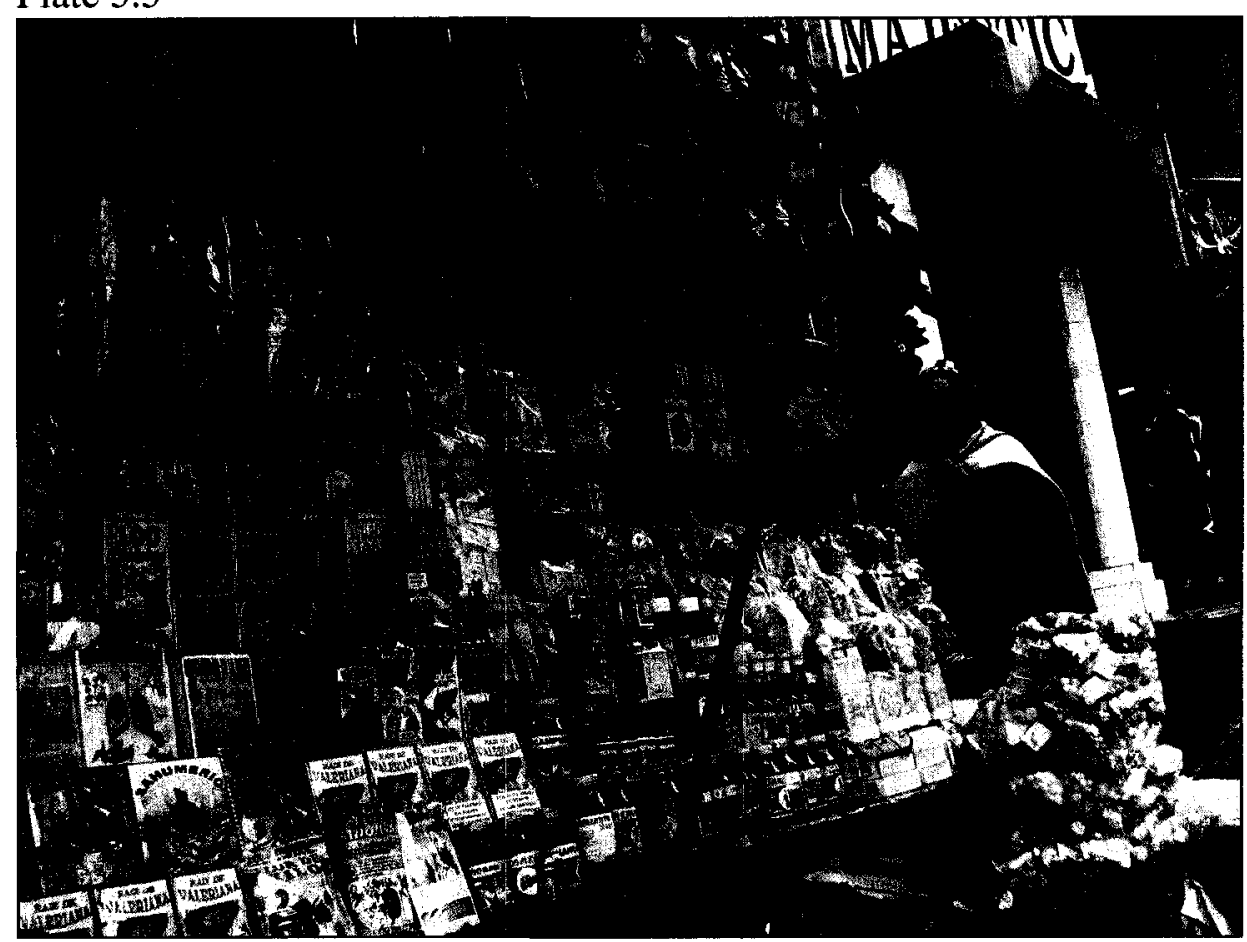

El Mercado de la Brujería. A selection of herbal remedies and ritual offerings for sale. Note dried llama fetuses hanging above shy vendor. La Paz, Bolivia, February 2008.

Plate 5.6

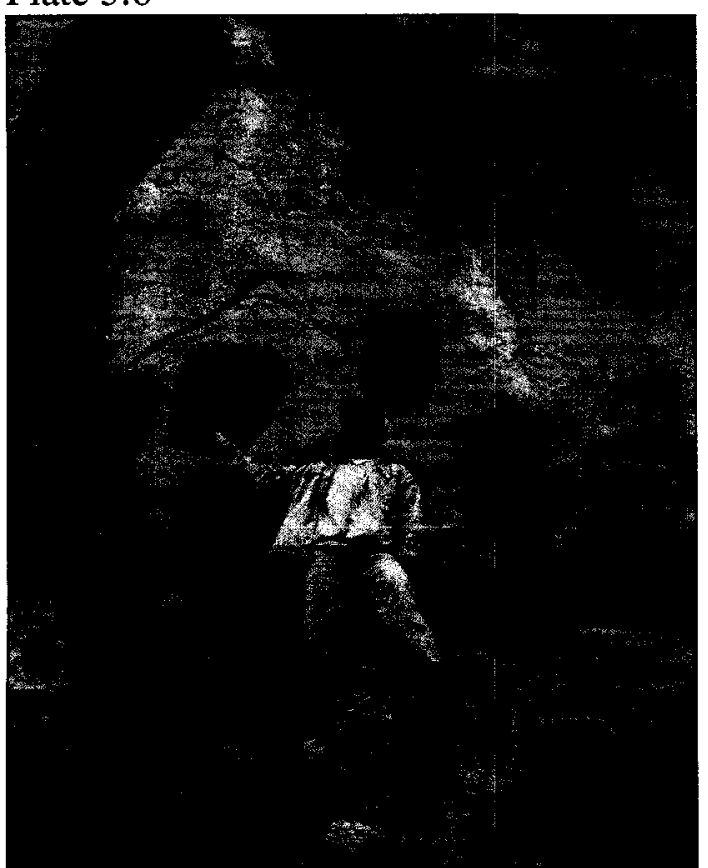

Pre-Incan burial cavities outside of Acobamba with Frederico's eldest son. When asked, he said that the burial cavities were from the "antiguos," an association that suggested the threatening presence of gentiles rather than the care of ancestors. Acobamba, February 2008 
Plate 5.7

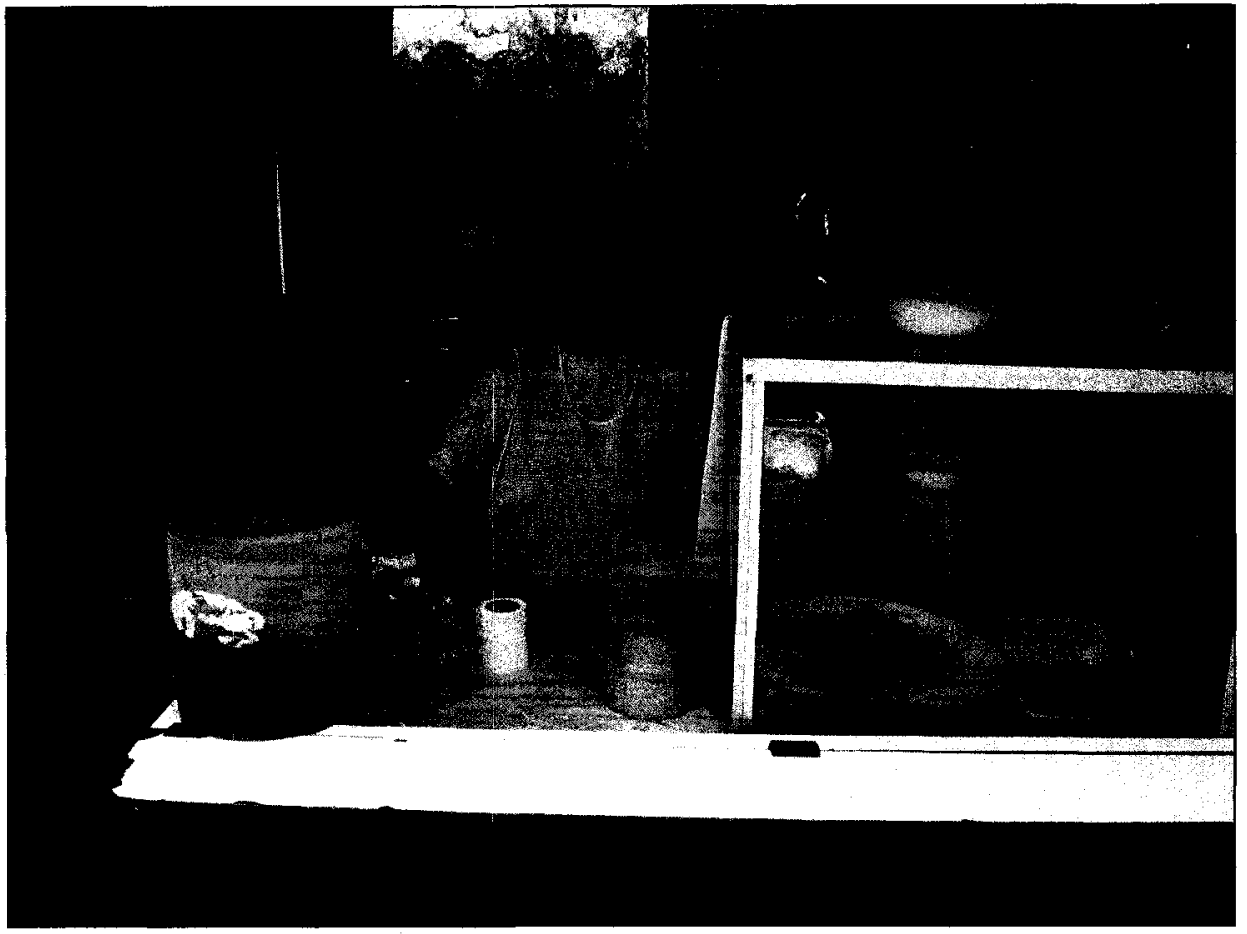

Susana at her cevichería in the informal section of the Mercado del Unión, Bayovar, San Juan de Lurigancho. Lima, March 2008.

Plate 5.8

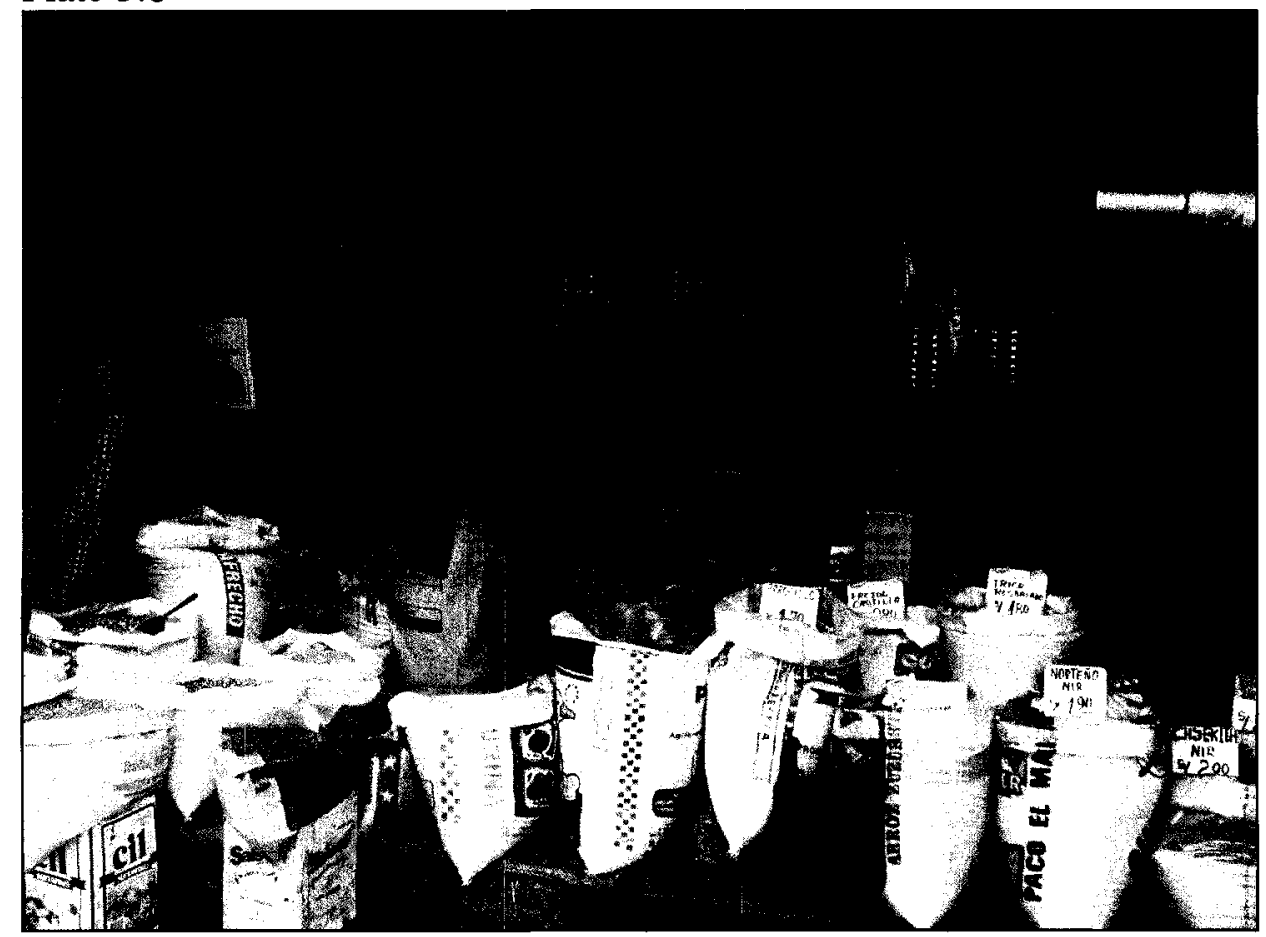

Pedro's brother at his abarrotes store in the formal section of the Mercado del Unión, Bayovar, San Juan de Lurigancho. Lima, August 2007. 


\section{Chapter 6: Circulation and "Modernity"}

Feeding is central to the circulation of life-energies through which people are endowed with health, well-being, fertility, and prosperity, and is an important force that drives progress and advancement. While Paucareños continue to feed specific Places, they also employ the logic of feeding and circulation in new contexts, such as urban markets. Although circulation is not broken by movements towards the city, neither it just simply "more of the same." This does not have to be problematic, for as Gadamer indicates, practice and understanding is constantly being revised in response to new situations (see Wachtcerhauser 2002).

In an earlier chapter, I implicitly suggested that people leave Paucará for the city for a variety of economic and personal reasons: the need for money, desire for education, desire to gain the knowledge and skills that will enable upward mobility, the need to create new social networks to make such mobility possible, a desire for personal progress and advancement. I think these concerns are real and significant factors in Paucareños' lives both in the countryside and the city, although as Sarah Lund Skar observes, it is possible that they are more "consequent intentions" formulated after the fact of actually moving rather than initial motivations (1994: 37, 44-45).

Skar found that in Matapuquio (Apurímac), movements to the city and the jungle involve a separation and distancing from the home community that illaqkuna ("absent ones," i.e. migrants) nevertheless remain connected to (Skar 1994: 70, 99). Skar rejects framing her argument in terms of migration, and instead adopts the local understanding of movements to urban places as separation. From the Matapuqeño perspective, urban 
migration is more like a "colonial" resettlement analogous to Incan mitma, in which displaced Matapuqeños remain connected to the larger whole of the ayllu in Matapuquio (Skar 1994: 31-33). These "colonies" or resettlements are conceptually placed in a tributary relationship to the "mother community," and as Skar demonstrates, illustrate "the bond between parts and whole, all sharing of the same essence" (1994: 260). From this (runa) perspective, "separation and reunion are central to the meaning" of migratory movements understood as colonization (Skar 1994: 260).

While Skar discusses migration in terms of separation (1994: 42), I intend to discuss migration in terms of sociality (e.g. erosion of dependency in the countryside, forging new ties of affinity in the city). I will follow Skar in setting political-economic factors to the side. Like Skar, I believe my ethnographic research can contribute more to gaining an understanding of the Andes than simply seeking to explain the motivations for or the empirical factors bearing on migration (see Skar 1994: 44-46). While I will note motivations for relocation and "pushes" and "pulls" to urban centres, ${ }^{42} \mathrm{I}$ am not concerned with "migration" as a widespread phenomena that is obviously changing the sociopolitical terrain of the highlands and indeed Peru in general (see for example Salman \& Zoomers 2003), or even as resulting in profound consequences for Andean communities, the cities that draw people, and fundamental experiences of personhood

${ }^{41}$ The term mitma refers to the "Inca practice of relocating loyal subjects in newly conquered territories or settling them in virgin areas to be brought under cultivation" (Skar 1994: 32).

${ }^{42}$ Although an explanation of or account for the pushes and pulls away from the countryside are not of primary interest here, some possibilities for urban migration will be noted here. Perhaps an earlier period of migration, possibly itself driven by a lack of land at one point in time and subsequent depopulation of the countryside, contributed to the ritual neglect of mountain spirits and increased reliance on monetary income. Alternatively, movements to urban areas could be pushed by the desires of local elites and kin, such as hacendados who brought promising youth to work for them in the city or relatives who encourage youth to follow them (see Skar 1994: 26-27, 86). At the same time however, there is ample evidence that Andeans themselves have historically chosen (and continue to choose) to engage in movements away from their home communities through migratory labour, petty marketing, and the pursuit of education (see Collins 1988; Larson \& Harris 1995; Paerregaard 1997). 
and place (see Skar 1994). What I am interested in is the relationship of migration (and movement more generally) to Andean strategies of progress and advancement, and the ways in which Andeans approach goals that may be seen as "modernizing" without actually being subsumable to a meta-narrative of "modernity."

Such desire for progress and advancement does play a significant role in movements between Paucará and the city. In addition to permanent migration, there are various other possible avenues towards less permanent movements and exchanges between the countryside and the city through which maintaining a household and advancement can be pursued: (1) impermanent migratory work in the agricultural offseason to supplement the household based in Paucará (e.g. Teofilia's husband, Jeremiah, Manuel); (2) education in the city with the intention to stay there (e.g. Pedro's older brother, Rosa and Manuel's son); (3) education in the city with the intention to return to Paucará (e.g. Frederico's older son who is studying law and expects to run for mayor some day); (4) remittances sent back home to support elderly parents (e.g. Verónica, Mamaku) and encomiendas brought to the city by visiting relatives (e.g. Susana's niece who works as a housemaid in Lima and visits the Bautistas on Sundays, whose mother still lives in Anta and sometimes sends agricultural products through her daughter); and (5) money saved by work in the city with the intention of improving the family in Paucará (e.g. Frederico's younger son who is saving his wages as a policeman so his parents can build a larger store and house).

Nevertheless, motivations for education and work opportunities may not be sufficient to keep a person in the city, as in the case of Rosa and Manuel's failed migration. In this case, as well as in permanent moves to the city without the intention of 
returning (for example, in the case of don Pedro), it seems there is something more going on than motivations relating to money and personal advancement. It has to do with how Paucareños perceive, experience, and relate to their Places. In some sense, Paucareños appear to have an "unbalanced" relationship with the mountain spirits and other emplaced powers: the circulatory logic of well-being, fertility, prosperity, and advancement is predicated on a balance of reciprocities. People both in the countryside and those who have moved to the city are neglecting their ritual obligations to the mountain spirits; at the same time, there is an erosion of dependency among fellow Paucareños which further drives movements away from Paucará.

More to the point, however, the relationships that Paucareños have to the mountain spirits and each other are tipping towards no longer being seen as productive and advancing in the countryside (thus the dispractice of ayni). This could be for a variety of reasons, including decreased trust and social solidarity after the senderista war and a re-evaluation of what is a desirable life that can only be accessed through ties and networks fed in the city. ${ }^{43}$ It seems that Paucareño society has reached a threshold of reciprocal efficacy and emergent desire. If Paucará follows more general trends throughout highland Peru, the present generation of adults has seen the most significant rise in urban migration in recent memory (see Dirección Técnica 2001); the household economies and life narratives of these adults are interconnected more than ever with periods of monetary labour in cities, as evidenced by the activities and experiences of the Paucareños I have been describing. Aspiring heads of households such as don Pedro are choosing permanent relocation in urban centres; if they cannot relocate themselves, they send their children to be educated and employed in the city, as in the cases of Rosa and

\footnotetext{
${ }^{43} \mathrm{I}$ am indebted to Peter Gose for his contribution in developing this argument and throughout this chapter.
} 
Manuel or Frederico. This experience and expectation is the new baseline for youth who are more informed of (and perhaps more desirous to attain) the opportunities that the city is seen as offering. These youth are, particularly in a place like Paucará, better connected to national Peruvian society and even international networks than previous generations, with access to better and more extensive transportation networks and easier modes of communication such as cell phones and the internet.

With fewer productive members of households remaining in the countryside, it is more difficult to draw upon extensive social networks for reciprocal labour or even maximize the potential productive capacities of individual households; with new desires emerging for better living conditions, consumer goods accessible only through cash, and exogenous knowledge and experiences, the countryside is re-evaluated as a place in which one is not able to comfortably maintain a household or advance as an individual.

Meanwhile, families continue to labour on their lands and feed the mountain spirits, but do not receive the abundance they hope for. Perhaps, as Paul Trawick (2003) has indicated for Arequipa, the land is indeed becoming less productive (see DIA 2006 for some suggestive statistics). Manuel pointed out to me that his potato field in places had but a few centimeters of soil above the bedrock; over the years the soil had been eroded by the rains and fallen into the ravine where the Río Wichjana lies below. The logical consequence perceived of this may be that the mountain spirits and the pachamama are not bestowing expected well-being and abundance on the people under their care, thereby calling into question the efficacy of fertility rituals or even the reciprocal contract itself. Many people commented that food stores were low and crops were limited in 2007 because the previous year a severe frost had destroyed many crops, 
including seed potatoes. But while Matapuqeños could address the pachamama (Sara

Mama) for aid and new seed corn when fertility left and crops failed (Skar 1994: 235236), Paucareños relied on the municipal government to provide much-needed seed potatoes.

Paucareños thus depart for the city more or less without the intention of returning. Contrast this with the case of Matapuquio, where travelers depart for urban and jungle milieus with not only an intention of returning, but a corporally-experienced threat to their state of being should they not maintain a connection to their home community. For example, the Matapuqeño traveler departs with a special talisman called an illa, a stone that is taken from local mountains through which one "is to receive the benefits of protection and fertility that only the apu can give" (Skar 1994: 67). Through this talisman and other items including foods "grown on ancestral lands" that are sent along as an encomienda or apachikui, travelers remain corporally connected to Matapuquio in spite of time and distance (Skar 1994: 56) and are strengthened so as to survive the shock of the urban and jungle milieus and to not "forget their lands and the village" (Skar 1994: 70, 99). Such forgetting is perceived above all in the rejection of "the reciprocal bonds between the illaqkuna, their lands, and their family in the village" (Skar 1994: 99). ${ }^{44}$

Since agricultural products "should be held within the sphere of social relations of reciprocity," there is a "strong taboo" in Matapuquio against the selling of foods that are

\footnotetext{
${ }^{44}$ In reference to the importance of the apachikui (commission delivered to outside settlements, i.e. agricultural products) and kachana (commission received by the home community, such as fruits and money from the jungle and clothing and radios from Lima), Skar says: "While this reciprocal exchange can clearly be related to the ecological adaptation specific to the Andes, in which control of different altitudinal zones and the institutionalized circulation of altitude-specific produce are integrated in a single system... for the bearers of the apachikui it is rather the connotation of ongoing obligation that is the central concern in all this effort. The gift of apachikui is not so much a part of the personal bearer of the commission as it is an encompassing kind of communication between groups to express mutual respect through the idiom of shared nourishing" (1994: 56-57).
} 
the product of family lands (Skar 1994: 94n8). From the Matapuqeño perspective, the consumption of foreign foods poses a problem for the "material continuity of the body" since food (and drink) is a "dynamic bonder between the person and the land" (Skar 1994: 56, 93). The food contained in the apachikui is a vehicle for the transmutation of the life-giving essence originating from the mountain spirits and the pachamama in the body of the traveler (Skar 1994: 56): "In the villagers' view, all of these foods are the very substance of what you are. Receiving these goods, you eat again of your lands and in substance become one again with that distant place" (Skar 1994: 58). Foods produced on family lands are thus "a life-giving substance that can be shared in various ways despite separation" (Skar 1994: 93).

As an embodiment of life-giving energies and a medium for building ties of affinity, food is an important way in which people continue to be corporally connected to their places of origin. This corporal continuity is particularly important for Matapuqeños, who move away from their home communities with every intention of returning once again (or at least maintaining their connection) to the whole. Things may be different for Paucareños, as many appear to move to the city without the intention of returning. From a Matapuqueño perspective, it would seem that Paucareños indeed forget their community of origin, no longer visiting relatives or regularly sending packages back and forth as apachikui and kachana.

However, while Paucareños appear disinvested from social networks in the countryside, and while they do not engage in networks invoking a common community of origin in the city, they do not forget the relationships they have to powers embodied in their Places. Nor do they undergo a radical break with the past and unequivocally opt for 
modernity (as suggested by Skar 1994: 217). Indeed, despite their desire for progress and advancement, in important ways Paucareños can be seen as not pursuing "modernity" at all, but rather uniquely Andean practices that do not conform to essentialistic notions of modernity or tradition.

The only explanation I received to a casual inquiry as to why the Bautista family moved to Lima was that a major fault developed in the structure of the house, which made it uninhabitable. Indeed, when I visited the abandoned Bautista farmhouse with Susana and Yhosef in September 2007, a long crack could be seen running down an inside wall. But I also know that half the family continued to live there for several years after Pedro moved to Lima to begin establishing a home there; their old farmhouse is also standing in what appears to be good condition today. There is also the obvious question as to why they did not simply fix, rebuild, or relocate the house. The family apparently had good fields and was prosperous enough to even sponsor the Fiesta de Mama Cocharcas one year. If they were healthy and prosperous in Paucará, why move to the outskirts of Lima to live in the dust and the heat, where every day they must struggle to find money to eat? Perhaps it had something to do with the emplaced powers who oversee the health and prosperity of this house, which faces the base of Cerro Calvario. Such a prominent crack indeed appears inauspicious for a household that is supposed to be looked over by this and other mountain spirits.

On another level I suspect it had something to do with don Pedro's ${ }^{45}$ own ambition for personal progress: to become educated (e.g. literate) and acquire foreign knowledge - in Skar's words, "learning and mastering expertise in a new and foreign

\footnotetext{
${ }^{45}$ Susana indicated to me that if she had the choice she would have remained in Paucará. It seems that she hoped their stay in Lima would not be permanent: she left a large chest of chuño in the storeroom of her house in Paucará, which was still good when she visited her home seven years later.
} 
context" (1994: 95n10, 223). As Skar indicates, I suspect this desired acquisition of knowledge and competency has more to do with "the internal state of the person" than an “abstract technique" (1994: 224):

Newly arrived illaqkuna emphasize the knowledge they wish to attain rather than the specific task through which they hope to acquire their ability. For both men and women, to be described as someone who knows how to work really well is tantamount to being designated a truly good person, an ideal Runa. The focus is on the knowledge and not on its application through work. (Skar 1994: 95)

Although he recognizes his ongoing challenges to make ends meet, don Pedro is proud of his achievements and relative success in the city. He owns a brick and concrete house that is big enough for his entire family, knows how to read and write enough to get by, and makes a living through his own initiative and perseverance, going door to door in wealthier neighbourhoods offering to do household repairs. He is a "self-made man": everything he has achieved and worked for in the city has been through his own labour and resourcefulness, which includes his considerable powers of persuasion and aptitude for forging bonds of affinity. At the same time, he evidently sees the blessing and benevolence of the mountain spirits as playing a crucial role in his success, as he regularly offers ritual foods to them and bathes in special herbs to increase his luck perhaps, as Skar suggests, to be endowed with the life-giving breath or sami of the mountain spirits (1994: 202, 210).

As this indicates, it appears that at least some Paucareños see a livelihood based in the countryside as not viable because there are more limited opportunities for networking and building desirable ties of affinity. Conversely, people see urban places as offering these opportunities for advancement through the establishment of relationships 
with others (ritual kin, coworkers, mentors, investors, etc.). This may not necessarily be in the (somewhat rigid) sense asserted by Paerregaard that the "real" motivation of Tapeño migration is "to stretch consanguineal as well as affinal bonds across the ruralurban divide and maximize the sibling group's control of resources in both worlds" (1997: 155) in a manner akin to ecological verticality (see also Skar 1994: 42-44; Murra 1975). Rather, it seems to be a more general extension of the creation of relationships of obligation and reciprocity that are essential to "get things done" and "progress" from an Andean perspective. Urban contexts provide people with new opportunities for affinity, and thus advancement that are not perceived as available in the countryside. These relationships of affinity can be seen in practices of feeding in their myriad ritual, market, production, and social contexts that have been under discussion.

Thus, people who strategically feed prospective business contacts and compadres in the city are not abandoning customary work relations and ties of affinity as seen in the countryside. Rather, they are using an Andean idiom of feeding to achieve in Lima what is no longer obtainable to the same extent in the Paucará: production, prosperity, progress, advancement, and in a general sense, health and well-being. Paucareños are forging new connections and contacts in ways that actively build on and even further develop the logic of the animating energy that flows from ultimate sources of well-being to people who further engage in productive and advancing exchanges amongst themselves.

The conceptual ground for this privileging of social networks is the circulatory system "in which all action eventually turns back on itself" (Allen 2002[1988]: 195). This circulatory vision of the Andean world is conceived as analogous to a hydraulic system 
(Allen 2002[1988]: 36, 194, 241; see also Gose 1994) in which flows of fertility, prosperity, wealth, and social solidarity move like currents from the mountain spirits, pachamama, and ancestors to the fields, animals, and humans through exchanges of work, food, and drink. This is sometimes well-articulated by referencing the concept of sami (for example Allen 2002[1988]), but it does not seem necessary to corporally connect people to one another and to their lands animated by various emplaced powers (see Lazar 2008; Seligmann 2004; Skar 1994). Skar observes this prominence of return in cyclical notions of time articulated in a notion of pacha (which can refer to earth, clothing, world, and time) that "incorporates aspects of both the temporal and the spatial," which in Matapuquio "[couples] land and ancestors, an association of place with an unspecified past" (1994: 172-173). ${ }^{46}$

Allen sums up this circulatory system and its various metaphysical, physical, social, ritual, spatial, temporal, and embodied aspects:

Runakuna experience a world full of circulating currents. The sami circulates through the world and vitalizes each thing according to its proper nature. Blown from coca leaves, the sami returns to the giver, just as streams flow down the mountainside into the deep tropical forest and from there return again to Sonqo. Some of the streams' vitalizing water evaporates into the air and returns as rain; some, the Runakuna say, flows back underground to break through the Earth's crust in Sonqo's puna marshes. The Wind, a river of air, roars out of his cave in the puna, rushes, [sic] about the mountainsides, and returns again to his home. The river of blood circulates through the human body. Human energy flows out in labor and returns in ayni. Generations pass into the same soil from which their ancestors sprang and from which they will nourish future generations. Time moves ahead like a river to drop from view into that subterranean interior that contains both past and future. (2002[1988]: 194-195)

\footnotetext{
46 "Basically the conceptual coupling [of space and time] is best demonstrated within the context of a sacred understanding whereby the venerated land and the ancestors become a unity within the cosmic context of the world and its epochs" (Skar 1994: 39).
} 
Although still powerful, this circulatory system is no longer working in Paucará in ways that people want it to. This is something that contributes to the decisions of people to move to the city, where they find that it is effective. I would suggest that "consequent intentions" for access to money, education, and personal progress aside, migration in Paucará is precipitated by a breakdown or fracturing of the circulation of energies, to some degree in the relationship that people have to their Places, but primarily in interpersonal relationships. Paucareños appear to leave the countryside because they no longer have so many people they can trust and depend on for mutual support or common goals. Throughout my fieldwork, it struck me that nuclear families seem to be looking into themselves for mutual aid and assistance; when bonds of affinity are to be made, it seems that outsiders are strategically chosen, such as gringos met on the street. ${ }^{47}$ Furthermore, when I was first brought to Paucará by the Bautistas, in their concern for me they told me to not trust anyone outside of the family, by which was meant anyone besides Mamaku and her grown children and young grandchildren. They were convinced that someone would "take advantage" of me; it was even suggested that an envious neighbour would come to Verónica's unprotected house in the night to rob a wealthy gringa.

Skar suggests that "the most valued aspect of social life" for Andeans is "having people to depend on" (1994: 38). With an erosion of social trust and dependency in the countryside, Paucará must indeed seem an unfruitful place in which to live, and certainly not one in which one can advance one's household and self in desired ways. When they establish themselves in the city, Paucareños do not seem to look back on a "lost whole,"

\footnotetext{
${ }^{47}$ This does bring up the question of what happened to the ayllu in Paucará, or where some wider community identification can be found for Paucareños. It is not something I am able to address in any extended way though present fieldwork, however; evidently much work remains to be done.
} 
but rather orient themselves with considerable hope and positive expectation towards future relationships and opportunities. Indeed, there is remarkably little sense of collective identity among Paucareño migrants. The only time I encountered a cultural club, apparently so important to other migrant groups (e.g. Skar 1994: Chapter 4; Paerregaard 1997: Chapter 8) was when Pedro and Susana attended a folkloric reenactment of the Fiesta de Santiago at the Federación Interdistrital de la Provincia de Acobamba - Huancavelica (FIPA) in Lima. They went to experience the Fiesta de Santiago since they could not travel to Paucará; a group of Paucareños, as well as other groups from districts in Acobamba, came to stage performances of key events surrounding the Fiesta de Santiago (including music, ritual offerings, and putting new cintas on bulls and sheep) in competition with one another (see also Paerregaard 1997: Chapter 8). Although they enjoyed the "spectacle," it was not an occasion to meet and visit with fellow Paurcareños living in Lima or traveling from Paucará. Indeed, the only extended family member who was there was Susana's niece who was visiting that Sunday.

Perhaps these clubs are important to other Paucareños (the Club Social Juventud Acombamba from Paucará was founded in 1950); however, I never observed Pedro and Susana or their children participating in community-centered events involving Paucareño migrants (or indeed members of their own neighbourhood, inhabited by migrants from various regions). Furthermore, to my eyes the Bautistas had remarkably little contact with family members both in Lima and Paucará. According to Skar, a focus of such clubs and relationships is to "generate a sense of their own collective identity through posing [the home community] as a distinct shared Other with which they interact" (1994: 38). In 
contrast, Paucareños (or at least the Bautistas) are not spending time being nostalgic for a "community" or "tradition" that they perceive as "losing" by moving to the city. Instead, they are pursuing goals that can be seen as "modernizing," but on their own terms.

The Bautistas like living in a house that has electricity and running water, and in a place that is not so rugged or cold. Yhosef and his siblings experienced great discomfort when they traveled to visit their maternal grandmother in Anta: "how the people suffer!" they commented, having forgotten what it was like. In Lima, the Bautistas prepare meals from foods almost exclusively purchased in the market on a natural gas stove rather than foods grown on family lands over dung-burning stoves. Although they savor the tastes, smells, and textures of foods from the highlands, they also enjoy the great diversity of dishes they are able to eat in the city. Pedro and Susana's children are all literate, speak Spanish fluently, can easily navigate through the unmarked streets of their neighbourhood and Lima's complicated, frenzied transportation system. They are extremely knowledgeable about how to make a living in Lima and like their parents strive to make their own opportunities in an unforgiving informal economy. They have ambitions for their futures that would be difficult to visualize in the countryside: the second daughter would like to work in an office, and the youngest son as a mechanic. Although the Bautistas struggle to make ends meet and face many challenges in the city, neither do they romanticize a pastoral life in the countryside, or wish to return to establish households in Paucará on lands they still own.

But while the Bautistas appear to have disassociated themselves from many reciprocal obligations to extended family members and fellow Paucareños, they have not separated themselves from obligations to mountain spirits and other sources of fertility, 
or the underlying logic of the circulatory system. Although the extent of their continuing identification with their community of origin is questionable (particularly for the children for whom Paucará is a distant memory), they are not obviously disoriented or displaced in the city.

A contrast to Matapuquio is again useful here. According to Skar, the separation from and subsequent objectification of the home community presents opportunities for disassociation and thus social fracturing from the greater whole:

Separation from family and place of origin gives scope for reflection on a personal history to an extent rarely possible within the relatively homogeneous lives of the village. In individual terms, there is much greater leeway to evaluate the relationships that one chooses to recognize. If one chooses to disassociate oneself from many of these obligations, there is an implication that the opting for modernity is unequivocal. (1994: 217)

Even if Matapuqeños do not elect "modernity," Skar suggests that they experience profound transformations in terms of personhood and space/time (see Skar 1994:

Chapters 6-7). These transformations can occur not only in a change of perspective (e.g. the process of objectification and distancing that migrants undergo by being away from their home communities), but also in a changes in one's state of being. For Matapuqeños, this possibility seems to be in part corporally experienced through the consumption of foreign foods, as evidenced by the importance of the apachikui sent along with the illaqkuna:

Food sent from the village in the apachikui reincorporates distant villagers into that universe, while food from other places can wean one away from that integral person/land relationship into another kind of world; a world in which money is used to acquire food. (Skar 1994: 93-94) 
In a somewhat different sentiment than I encountered among Paucareños in Lima ${ }^{48}$ Matapuqeños say that in the countryside one eats the land, while in the city one eats money (Skar 1994: 94). ${ }^{49}$ Skar suggests that for Matapuqeños, money is divorced from the fertility and prosperity of the mountain spirits and pachamama transmitted through foods from the village. Therefore, in contrast to what I argued in the preceding chapter, Skar found that for Matapuqeños in the city, "wealth is divorced from agriculture" and so is "generat[ed] on different terms" (Skar 1994: 226): ${ }^{.0}$

Divorced from the land and the context of the ancestors, the source of wealth becomes disassociated from fecundity, and its affinity with some kind of life force inherent within the "moral" person is discontinuous. Wealth as the result of work in the city is apart from the person and becomes associated with a separate luck more in keeping with our ideas of fate. (Skar 1994: 226)

However, for don Pedro, work in the city (although different in form and content) is not generated on separate terms than in agro-pastoral production. His ritual practices that are aimed at enhancing his "luck" in his work and life more generally are about the circulation of the same life-giving energy that is in operation in the countryside. He bathes with the herb ruda; adorns himself with this herb as well as rosaries and specially purchased talismans featuring certain stones, seeds, and pictures of particular saints; consults tarot cards; makes ritual mesas with written notes of recomendación; and

\footnotetext{
${ }^{48}$ The Bautistas commented that in Lima, one works to obtain money with which to buy food, whereas in Paucará, one works to grow food to eat. The implications, however, are I believe different than in the case for Matapuquio. For the Bautistas, the monetization of their livelihood strategies does not reflect a different ontological orientation or moral universe, but rather their experience that they continue to struggle to make a living despite the high hopes they had, and continue to have, for their lives in the city.

${ }^{49}$ The connotation of the mestizo Other should not go unnoted here, as early chroniclers such as Guaman Poma de Ayala took note of the Incan understanding that Spaniards indeed ate money (1980[1613]: 267). ${ }^{50}$ Although Skar does note elsewhere that other ethnographers have found that there is a "close association between money and food in Andean conceptions of fertility and sacrifice. Both are intrinsic to the attributes of the moral person in his relations with the sacred beings of the landscape" (Skar 1994: 149n9).
} 
performs special cleansing baths to guarantee prosperity, health, and well-being from benevolent powers including God, saints, and the mountain spirits.

These luck-enhancing practices take on additional significance in light of how don Pedro makes a living: through his own initiative, perseverance, and persuasive skill by knocking on doors to provide a service. As in many sectors of the informal economy, the income obtained through this work is unstable. Some days, one has large windfalls, and others, one is beset with misfortune. Having "good" or "bad luck" is important for ambulantes who seek to not only understand but also alter or direct the outcomes of their work. As suggested below, practices aimed at the alteration of outcomes are also about the alteration of states of being. Like ritual plates and acts of feeding that push recipients towards desired (but indeterminate) goals, luck-enhancing practices move recipients into an auspicious place by changing their state of being through the endowment of the same life-giving energies. ${ }^{51}$

Furthermore, in the city as in the countryside, human labour is a necessary accompaniment to divine benevolence. While campesinos in the highlands can expect their fields to be prosperous if they feed the mountain spirits, their fields will not produce anything if they do not labour in them (see Gose 1994: 131). Similarly, in the city people must work to sell something or perform a service, but if they ritually attend to life-giving powers and make themselves receptive to the circulation of life-energy as seen in this distinctly Andean conception of luck, their work will be fruitful.

For example, before I left for Paucará, don Pedro offered to give me a ritual bath to ensure my safety and health in the countryside and success in my project. On this and

\footnotetext{
${ }^{51}$ Compare with Skar's characterization of luck in the countryside as "not something that is encountered by chance out in the world [as she asserts is the case for Matapuqeños in the city] but is inextricably bound up with one's own well-being" (1994: 226).
} 
other occasions, ${ }^{52}$ he saw himself as looking after me as an honoured guest and daughterlike figure, and contributing what he could to ensure my well-being and success. He saw my travels through the countryside as dangerous for various reasons: the commonness of road accidents, the threat of swindlers and robbers, and the fact that I was unaccustomed to the climate and could "chocar" with the mountain spirits. At the same time, he wanted to ensure my success through addressing these same mountain spirits as well as paramount sources of prosperity and well-being, such as God and the pachamama.

In my bathing suit and by the light of candles, don Pedro prayed over me, reading from a book of Catholic prayers while seated behind me with his hands over my head. $\mathrm{He}$ then lightly struck me with bunches of two herbs all over my body (ruda and I believe marco), while emphatically repeating what he asked for me: good luck, health, safety, success. Once the herbs were used up (pieces of which had fallen to the floor), he took three spools of thread coloured red, yellow, and green (red is for love; yellow for luck; and green for wealth and prosperity). These he took together and broke by strands over my body (arms, legs, trunk, neck, and head) while continuing to incant his prayer, until the spools were used up. At the end of this stage, he had me turn three times counterclockwise.

Next he had me stand in the shower for the bath. He and Susana had prepared the hot water beforehand, which was mixed with numerous bottles of purchased herbal concentrates. There were ten or more bottles, each with a specific mix of herbs and flowers for a particular purpose. (These and other ritual and health items can be found at

\footnotetext{
${ }^{52}$ These other occasions include sending me to the countryside with talismans of pictures of saints accompanied by special stones and seeds and soap made of ruda; reading my tarot cards; bringing a recomendación to the hilltop above his neighbourhood on my behalf; a Christmas present of special ribbons tied around my wrists to bind me to good luck; and an identical ritual bath before I returned to Canada with the express purpose of successfully completing my studies and finding a job.
} 
a specialized street market in Gamarra). Other herbs and flowers were mixed in with the water whole, making a hot and fragrant bath water. This he threw by the bucketful onto me, which he told me to rub over me as if I were bathing. At the same time, he continued to pray for my success and health. He told me to think purposefully on what I hoped for as well, for to have correct intent and "faith" is a necessary component of the ritual's efficacy. When all the water was used up, he had me again turn three times counterclockwise. Then I was to put on my underwear inside-out and rest in bed, so that I was kept purified and unaffected by chance encounters in the street before departing the next morning.

The ostensible purpose of this ritual bath was to increase my "luck." What exactly did don Pedro mean by this? He certainly hoped that it would increase the likelihood of auspicious, safe, and fruitful encounters in my travels, and protect me from possible accident, sickness, and misfortune. The bath water was said to "wash away" my "bad luck," leaving me "clean and pure" (limpia) for the road ahead of me. The counterclockwise rotation of the body and inverted nature of intimate clothing seems to further emphasize the repelling of bad luck.

But in some way the ritual bath also seems to make one receptive to the benevolence of life-giving powers. Skar suggests in passing that an invocation of luck is to appeal to the life-giving power (sami) of the mountain spirits (1994: 202, 210). I suspect that don Pedro's supplications for luck have a similar process of circulation at work as in agro-pastoral rituals, in which the life-giving energies of benevolent mountain spirits, the pachamama, and God flow from their source to the recipient. Moreover, in making one receptive to these life-giving energies, the ritual bath also seems to change 
one's state of being: it changes one's state from that of "bad luck" to that of "good luck." This suggests that in health and progress, circulation has more to do with states of beingin-the-world rather than determinate goals or reified ends (comparable to the "application of knowledge" in specific tasks that is obtained by illaqkuna as a secondary outcome of changing their state of being by obtaining a more general knowledge by living in the city as discussed by Skar).

Don Pedro regularly performs such costly cleansing rituals for himself, his family members, and acquaintances. The bath changes one's state to increase one's good luck and bestows the benevolence and animating life-energy on recipients, and is directed towards at once maintaining one's health and well-being and improving one's prospects for making a living in an unpredictable and self-reliant environment. But what is at stake here in a larger sense? What is it about the Place of the city that compels don Pedro and his family to undergo such rituals?

Timothy Oakes says that Place is the intersection of meaningful identity with immediate agency - identification and action - which is "derived from linkages across space and time" (1997: 510). Do Paucareños continue to "identify with" (Brubaker \& Cooper 2000) their Places? Do they, as Oakes suggests, experience their emplacement (whether in the countryside or the city) as the location of their self-identity and action? Alternatively, do they, as the narrative of modernity proposes, become displaced by migratory movements?

Casey (1996) would say that people can never really be displaced, because being emplaced is primary to the experience of being-in-the-world. But Oakes offers a different approach, one in which people remember or imagine places they are not in at the 
moment. Travelers returning to home communities find these same places changed (just as they have been changed themselves); others may hope for existence in a place that is currently beyond their experience, for example one in which work and opportunities are plentiful. Oakes sees Place as an idea in constant transition, movement, and process. Thus, to leave place or to feel out of place - to experience displacement - is a "fundamental part of the experience of place, rather than an aberration introduced by the forces of capitalist restructuring" (1997: 523; cf. Harvey 1990). Oakes is specifically interested in Place under conditions of modernity, and ultimately sees Place as the "landscape of modernity's paradoxes and contradictions" (1997: 509). He elaborates this state of modernity as the tension between "the exhilarating possibilities of modernization and a profound sense of loss" (1997: 511; see also Harvey 1990: Chapter 2). From this vantage point, people hope to forge new pathways and realize self-determined goals, yet they experience disorientation and groundlessness in new socio-spatial milieus.

As I have been arguing, however, this state of "modernity" does not offer a satisfactory explanation for Paucareños' lives and experiences, just as the intent of their progress and advancement is not "modernization" per se. Their lives and experiences are framed and informed by autochthonous concerns and understandings, in which people remain corporally connected to their Places despite time and distance, and in which the remembrance of past exchanges in the circulation of energies, foods, and reciprocities in various contexts is overshadowed by the expectation of future prosperity and prospective social bonds, regardless of the spatial-temporal location. ${ }^{53}$

\footnotetext{
${ }^{53} \mathrm{I}$ am indebted to Frances Slaney for indicating the primacy of future outcomes in the logic of a circulatory system. In a conference paper from 2007, she observes that "Contrary to Western expectations, to live within a sacrificial circulatory system is to adopt a universalizing and forward-looking orientation, and not to dwell on the past. Memory is not the source of positive appreciation for life (or culture, or
} 
Yet the account of modernity offered by Oakes is compelling in other ways, for Paucareños indeed are impassioned by the possibilities offered by urban residence and competency, education and literacy, and connections to new people (see also Skar 1994). And while Paucareños are not held back by a "sense of loss" or even a sense of "displacement" - by which nostalgic connections to migrant clubs or a sense of threatened traditions or precarious cultural identity may be maintained - they do experience a tension, one that can be seen in the apparent erosion of dependency in the countryside and the ambivalent malevolence of emplaced powers who are supposed to bring luck and well-being rather than sickness and misfortune. This tension, however, seems to have more to do with the "tipping point" of circulatory efficacy in Paucareño society discussed above, rather than the inherent "alienation" of "modernity."

In short, "modernity" is not what is at stake here. The Andean context in fact presents a problem for the meta-narrative of modernity, because it simply does not fit with the expected displacement, disorientation, and weightlessness that are thought to result as a consequence of the exhilarating (but unhinged) possibilities of radical individual determination and agency brought on by modernity. Rather, in historical and contemporary contexts Andean people can be seen as in constant movement, transition, and process: through Incan relocation and colonization under mitma; Spanish reducción; the dispersal of subsistence and kin networks through strategies of ecological verticality; the destruction and abandonment brought on by war; and migratory labour ranging from self-motivated petty marketing, to pulls of hacendados in cities, to a desire for new economic and education opportunities. Yet throughout time and despite distance, Andean

kinship). Looking back is an impediment to the proper circulation of life forms and so is an unhealthy, parochial perspective on life and sociality." 
communities have persevered, and individuals have pursued personal visions of wellbeing and advancement while remaining connected to the circulatory system of the cosmos. While the configurations of "community" are obviously changed by affinity with the city, there is something not altogether new taking place for Paucareños in Lima. Through these and other movements, Andeans transform their states of being and their emplacement as being-in-the-world. 
Plate 6.1

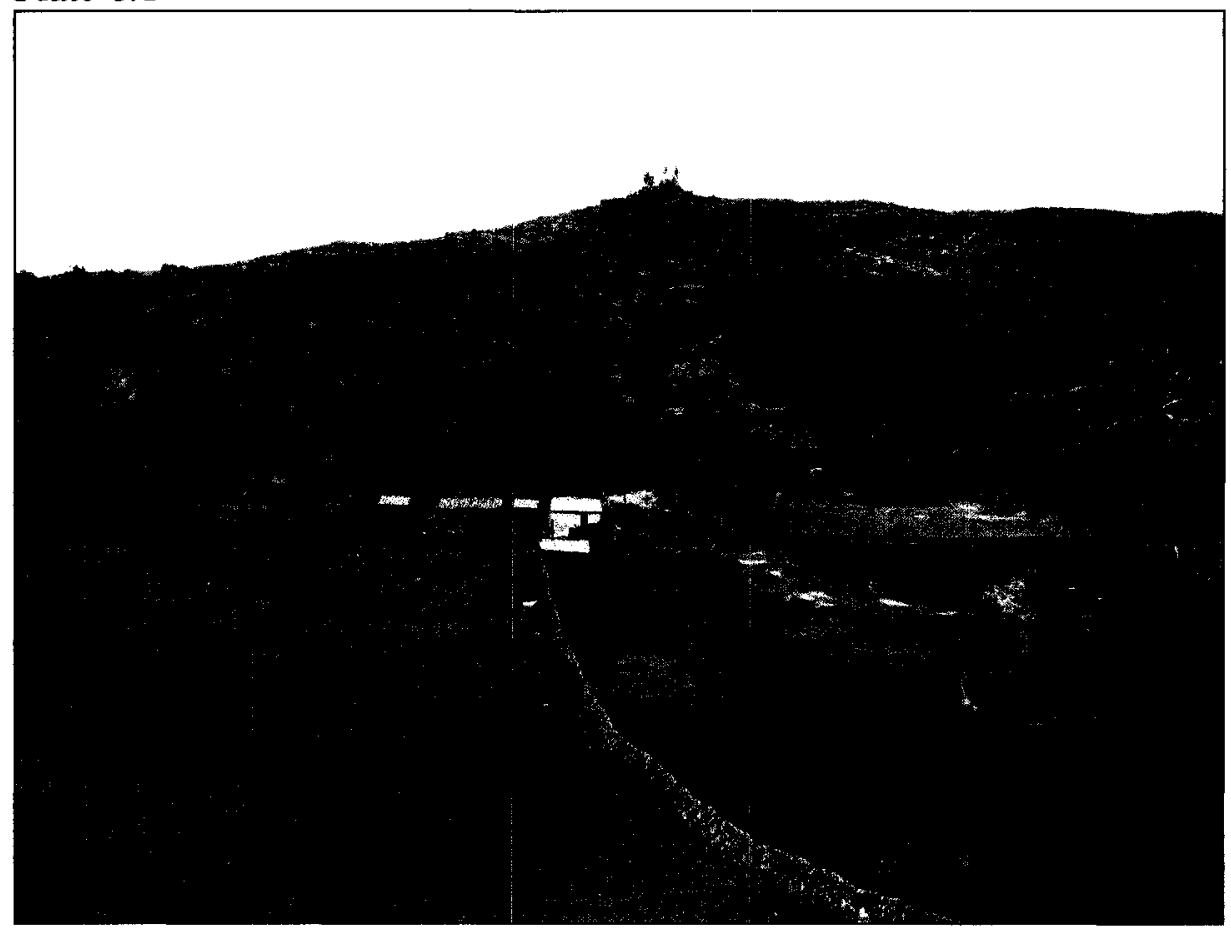

The abandoned Bautista homestead, with road leading to Paucará and Cerro Calvario in background. Paucará, January 312008.

\section{Plate 6.2}

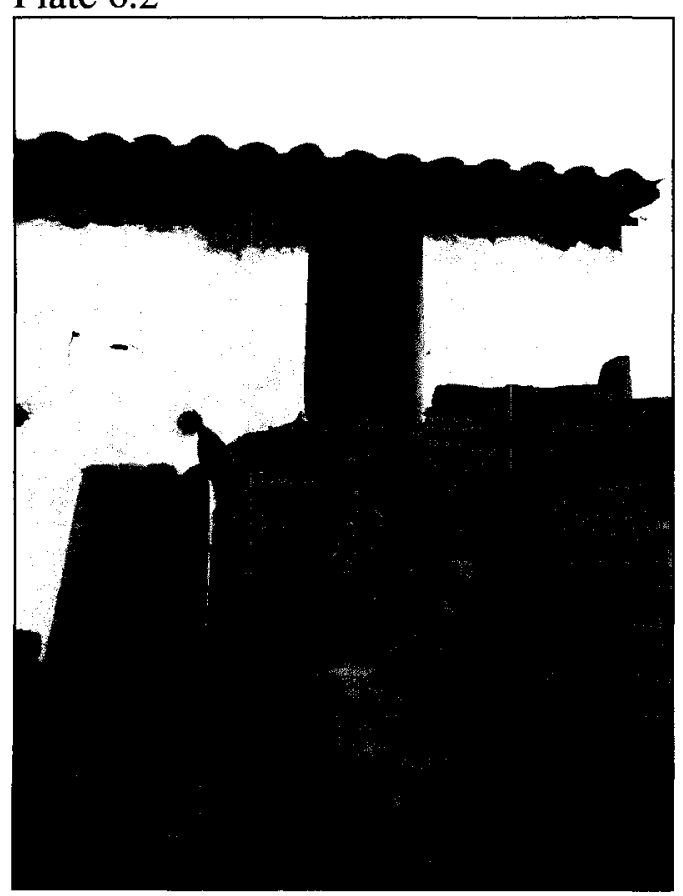

Close-up of Pedro and Susana's old house. Paucará, September 62007.

\section{Plate 6.3}

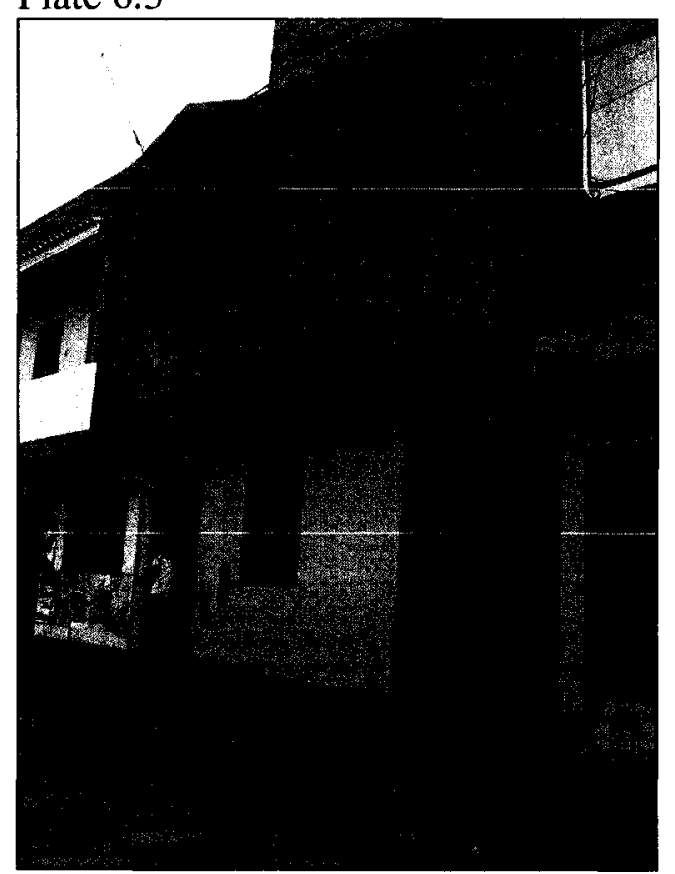

Pedro and Susana's cement and brick house in Bayovar, San Juan de Lurigancho. Their middle daughter stands in the doorway. Lima, March 2008. 
Plate 6.4

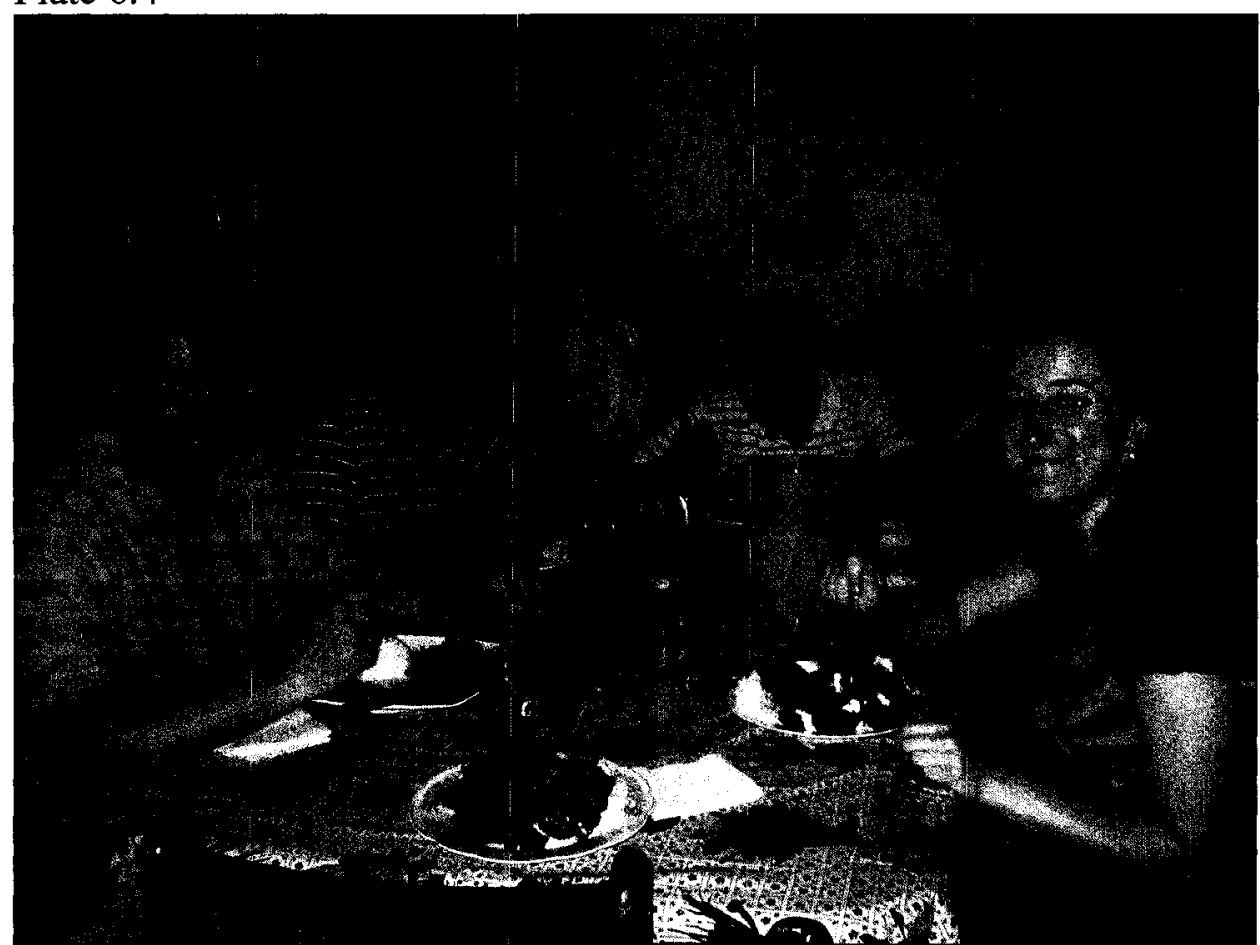

Yhosef invites a tourist to have a meal in his family's home, with whom he hopes to establish a work relationship. From left to right: the American tourist, Yhosef, Mamaku (still in Lima recovering from her sickness), Susana's son-in-law, Susana, ethnographer. Bayovar, San Juan de Lurigancho, Lima, February 2008.

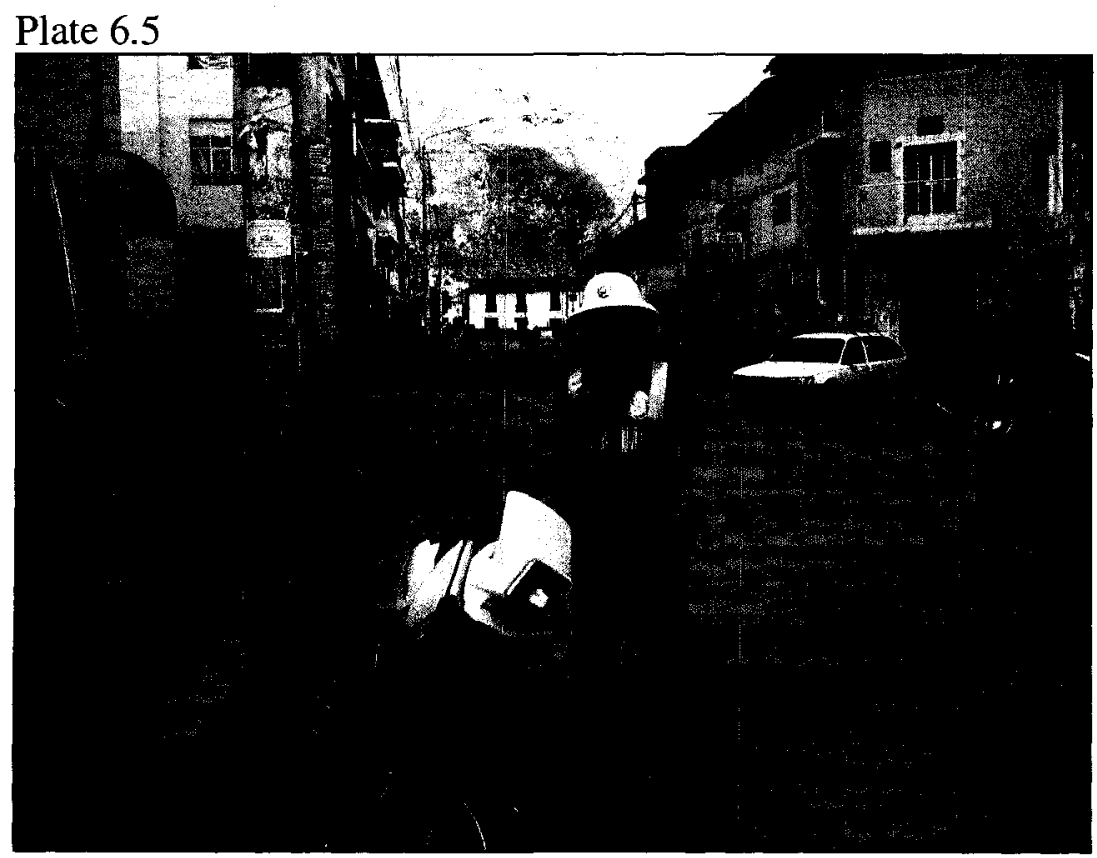

Frederico's second son is a policeman in the city of Huancavelica. With money from his regular salary, his parents plan to build a larger store and house in Paucará. Huancavelica, September 2007. 


\section{Plate 6.6}

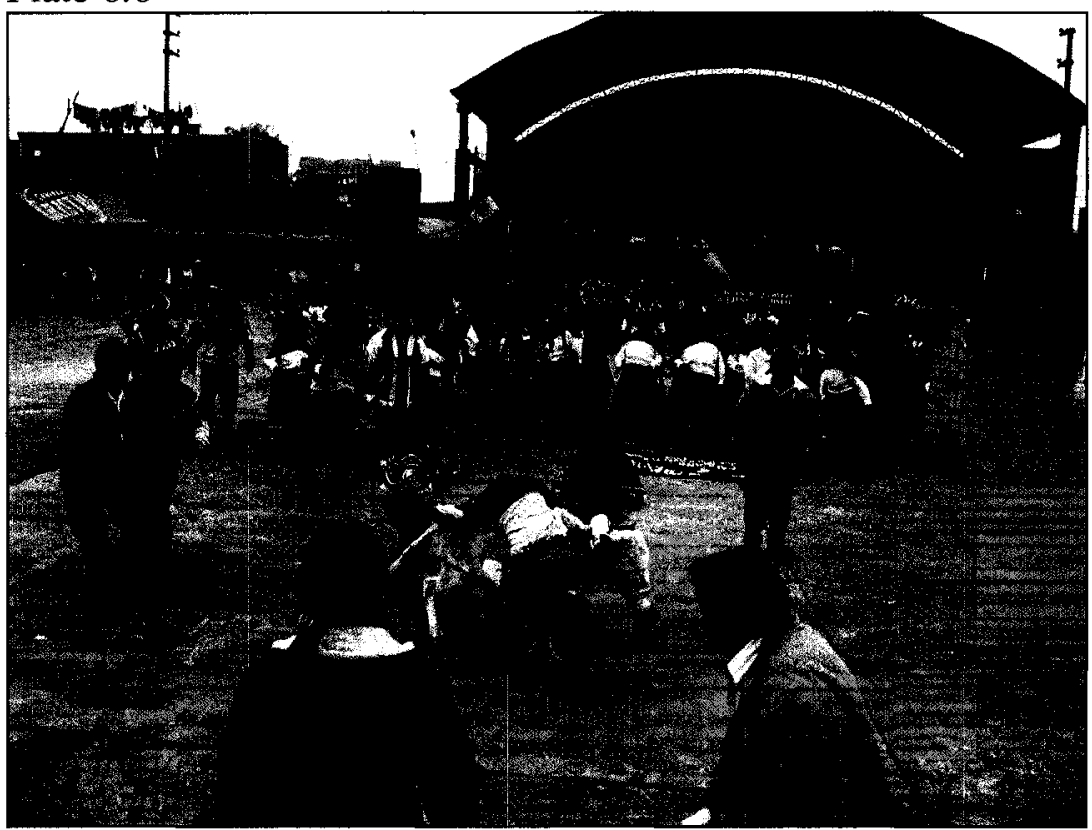

Re-enactment of the Fiesta de Santiago. Paucareños travel to Lima for the benefit of migrants who are unable to return home. The crowd is much entertained by the spectacle of boys trying to harness a calf. Note Peruvian flag and judges on stage in background. The stage reads: "Federación Interdistrital de la Provincia de Acobamba - Huancavelica." FIPA, Lima, August 12007.

Plate 6.7

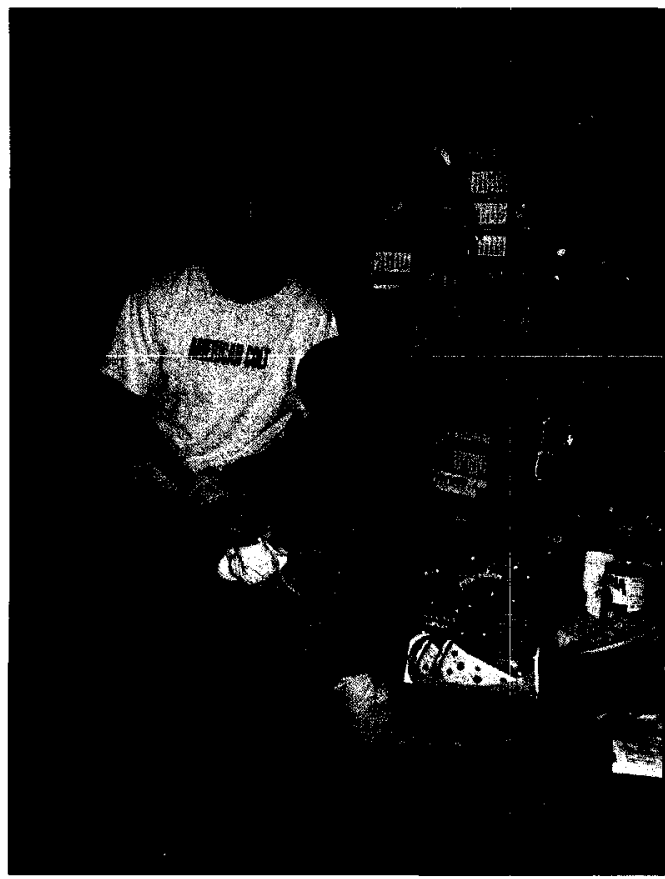

Three generations. Verónica visits Lima for her son's wedding at Christmas. Shown here with Alfonso and his new boy. Bayovar, San Juan de Lurigancho, Lima, December 2007. 


\section{Conclusion}

Food and other consumables such as alcohol and coca are a medium for the lifegiving energy or sami inherent in all matter, as well as for social relationships that connect Andeans to their Places and to each other. Through the feeding of others in contexts both formal and informal, ties of affinity are acknowledged and maintained, business relationships are forged, and social identities are created. At the same time, through the idiom of feeding, these consumables are a vehicle for the circulation of sami, the fertilizing and animating essence that derives from divine powers (God, saints and virgins, the mountain spirits, the pachamama), who are the ultimate source of abundance, prosperity, health, and well-being. The feeding of these divine powers as well as other social actors is necessary for Paucareños to "progress" and "advance" both in the countryside and the city. The logic of this circulatory system and the driving forces of feeding are thus carried into new contexts and places (cf. Bourdieu 1990[1980]), where urban migrants are able to pursue uniquely Andean notions of progress and advancement better than they can in the countryside. Although Andeans can be seen as perceiving new possible "horizons" (Gadamer 2004[1975]) for their lives - for example, with new frontiers of desire for work and standard of living - the manner in which their goals are considered achievable continues to rely on the feeding of life-giving powers and prospectively advantageous social others.

An idiom of feeding thus connects Andean ritual practices with distinctly Andean strategies for "progress" and "advancement." Agricultural and pastoral rituals are directed at divine powers embodied in the landscape to ensure fertility, prosperity, health, 
and well-being. In the countryside, offerings or payments of coca leaves, chicha, wine, and other alcohol, and other consumables are made to local mountain spirits, the pachamama, and God at key points in the agricultural calendar, as well as for special needs that arise during the year, such as in times of illness or before setting out on a journey. Similar ritual payments are also offered to diablos that exist on the wind or in pools of water that are found to cause illness or misfortune. Andean migrants who travel or move to cities in the hopes of better work and education opportunities continue to make ritual offerings to divine sources of prosperity and perform luck-enhancing rituals that appeal to these powers to improve their livelihood strategies in self-employment ventures in the informal economy.

This idiom of feeding is important in two key ways. The first is the social context that is forged through feeding. In a general sense, feeding creates a social context in which the recipient is obligated or expected to reciprocate in some manner. Ritual offerings and payments are necessary not just because forces both benevolent and malevolent are hungry and must be paid, but because reciprocal exchange is essential to fertility and productivity. The ethnographic literature demonstrates that this is the case in market and mining contexts just as it is in agro-pastoral production. Similarly, the feeding of kin members, compadres, clients, and business associates is an important vehicle for establishing and maintaining social affinity or a relationship of mutual benefit. Feeding has a force and efficacy that is at once social and ritual, and thus the feeding of divine figures is hermeneutically connected to the feeding of social actors.

The second way in which the idiom of feeding is important is as a vehicle for the continued circulation of fertilizing and animating energies, whether the act of feedings is 
framed as a gift, payment, or sacrifice. In the ethnographic literature, this life-giving energy is identified as sami. A multitude of practices, both formal and informal in nature, indicate that continued exchange and circulation is likewise important for Paucareños. Paucareños have reciprocal obligations to feed local mountain spirits who oversee the fertility and prosperity of their crops and herds; they also have reciprocal obligations to other community members to get things done and progress.

In agro-pastoral production, mountain spirits ensure the continued fertility and abundance of the crops and herds by directing this animating energy (sami) through water to the fields and pastures. At the same time, ritual offerings direct the sami inherent in food and alcohol back to the mountains from whence it was extracted. In other words, offerings and payments of consumables (as embodiments of sami) are the manner in which this essential energy stays in circulation by being directed back to divine sources. Such complementary reciprocal obligations is said to "advance" production.

Similarly, feeding compadres, business associates, and clients "advances" social relations and opportunities that are key to success and prosperity in the informal economy, in which the majority of Andean migrants make a living. Like ritual plates offered to divine powers, plates of cuy and potatoes or chicken and rice push the recipient towards a desired goal. Without creating a context of obligation for reciprocal exchange (often but not exclusively crystallized in an act of feeding), one cannot hope to advance very much. Likewise, the luck-enhancing rituals that are undertaken by migrant Paucareños who make a living on the streets of Lima move recipients into an auspicious place by changing their state of being through the endowment of the same life-giving energies. 
In short, feeding “advances” agro-pastoral and market-based production as modes of livelihood in strategic ways. At the same time, the feeding of social relationships is also about "progress" in the sense of movement onwards for the betterment of the household and family. In this sense, feeding can also push social actors towards hopedfor (yet indeterminate) outcomes; advance one's relationship over time (for example, from guest to compadre); and lead to social dynamism and movement generally (for example, in keeping market relations amiable and stable), as feeding and exchanges of food are so integral to Andean society in so many ways. Feeding in the field, the mine, the market, and the home continues to be the practical "logical consequence" of the pump-like movements of obligation and reciprocity in the Andes in which life-giving energies are circulated.

This analytical connection between ritual practices in the countryside and the city has sought to illuminate the force of distinctly Andean practices that are used to prosper and progress in contexts that include subsistence production, and market-based exchange, and sociality in general. This idiom of feeding is not practically or conceptually separated into domains of the sacred and profane or the countryside and the city. Rather, it is a strategy that can be (and is) applied to various contexts in which Andeans seek to make a prosperous livelihood.

The tentative conclusion that has emerged from these migratory concerns proposes that urban contexts provide Paucareños with new opportunities for affinity, and thus advancement that are not perceived as available in the countryside. In these urban contexts, Paucareños continue to feed social others and divine powers to "advance" and "progress." Thus, migrants who strategically feed prospective business contacts and 
compadres in the city are not abandoning customary work relations and ties of affinity as seen in the countryside. Rather, they are using an Andean idiom of feeding to achieve in Lima what is no longer obtainable to the same extent in Paucará: production, prosperity, progress, advancement, and in a general sense, health and well-being. Paucareños are forging new social connections in ways that actively build on and further develop the logic of the animating energy that flows from ultimate sources of well-being to people who further engage in productive and advancing exchanges amongst themselves.

The meta-narrative of modernity does not fully account for the motivations and experiences of Paucareño migrants, just as the intent of their progress and advancement is not modernization per se. Their lives and experiences are framed and informed by autochthonous concerns and understandings, in which people remain corporally connected to their natal communities and the divine powers embodied in specific places despite time and distance, and in which the remembrance of past exchanges in the circulation of energies, foods, and reciprocities in various contexts is overlaid with the expectation of future prosperity and prospective social bonds, regardless of spatialtemporal location. More research is indeed necessary to determine what broader implications this has to urban migration and lo andino today. 


\section{References}

Allen, Catherine

2002 (1988)

The Hold Life Has: Coca and Cultural Identity in an Andean Community ( $2^{\text {nd }}$ ed.).

Washington: Smithsonian Institution Press.

Alston, William

1956

Pragmatism and the Theory of Signs in Peirce. Philosophy and Phenomenological

Research 17(1): 79-88.

Annis, Sheldon

1987

God and Production in a Guatemalan Town. Austin: University of Texas Press.

Babb, Florence

1989

Between Field and Cooking Pot: The Political Economy of Marketwomen in Peru.

Austin: University of Texas Press.

Bastien, Joseph

1978

Mountain of the Condor: Metaphor and Ritual in an Andean Ayllu. Prospect Heights, IL:

Waveland Press.

Bontekoe, Ronald

1996

"Circular Thinking: Vicious and Otherwise." In Ronald Bontekoe, Dimensions of the

Hermeneutic Circle, pp. 1-11. New Jersey: Humanities Press.

Bourdieu, Pierre.

1990 (1980)

The Logic of Practice (trans. Richard Nice). Stanford: Stanford University Press.

Brubaker, Rogers \& Frederick Cooper

2000

Beyond "Identity." Theory and Society 29(1): 1-47.

Buechler, Hans \& Judith-Maria Buechler

1996

The World of Sofia Velasquez: The Autobiography of a Bolivian Market Vendor. New York: Columbia University Press. 
Cabieses, Fernando

1997

Cien Siglos de Pan: 10,000 años de alimentación en el Perú ( $2^{\text {nd }}$ ed.). Lima: Universidad de San Martín de Porres.

Casey, Edward

1996

"How to Get from Space to Place in a Fairly Short Stretch of Time: Phenomenological Prolegomena." In Steven Feld \& Keith H. Basso (eds.), Senses of Place, pp. 13-52. Santa Fe: School of American Research Press.

Collins, Jane

1988

Unseasonal Migrations: The Effects of Rural Labor Scarcity in Peru. Princeton:

Princeton University Press.

Counihan, Carole

2004

Around the Tuscan Table: Food, Family, and Gender in Twentieth-Century Florence.

New York and London: Routledge.

Crandon-Malamud, Libbet

1991

From the Fat of Our Souls: Social Change, Political Process, and Medical Pluralism in Bolivia. Berkeley: University of California Press.

Cutipa, Sabino, Raymundo Aguirre, Rosendo Ccosi, \& Tito Condori

2004

“"Qepa mama': Madra trama de la vida.” In Ana María Fries (ed.), Sabores y Saberes:

Comida campesina andina, pp. 89-104. Lima: Proyecto Andino de Technologías

Campesinas (PRATEC).

Daniel, Valentine

1984

"Introduction" in Fluid Signs: Being a Person the Tamil Way, pp. 1-57. Berkeley:

University of California Press.

Dirección de Información Agraria (DIA)

2006

Compendio Estadístico Agrario 1996-2005. Dirección Regional Agraria Huancavelica.

Dirreción Técnica de Demografía e Indicadores Sociales

2001

Peru: Estimaciones y Proyecciones de Población, 1950-2050. Boletin de Análisis

Demográfico No. 35. Lima: INEI. 
Dostal, Robert (ed.)

2002

The Cambridge Companion to Gadamer. Cambridge: Cambridge University Press.

Escamilo Cárdenas, Simón

2005

Recuperación de productos natives de los Andes: kiwicha y maca. Revista de

Antropología: 193-201.

Fuenzalida Vollmar, Fernando

1980

Santiago y el Wamani: Aspectos de un Culto Pagano en Moya. Debates en Antropología 5: 155-187.

Fuller, Norma

2003

Work and Masculinity among Peruvian Urban Men. United Nations Division for the Advancement of Women (DAW). EGM/Men-Boys-GE/2003/EP.9.

Gadamer, Hans-Georg

2004 (1975)

Truth and Method ( $2^{\text {nd }}$ ed., trans. Joel Weinsheimer \& Donald Marshall). London and New York: Continuum.

Gelles, Paul

2000

Water and Power in Highland Peru: The Cultural Politics of Irrigation and

Development. New Jersey: Rutgers University Press.

Gose, Peter

1991

House Rethatching in an Andean Annual Cycle: Practice, Meaning, and Contradiction. American Ethnologist 18(1): 39-66.

Gose, Peter

1994

Deathly Waters and Hungry Mountains: Agrarian Ritual and Class Formation in an Andean Town. Toronto: University of Toronto Press.

Gose, Peter

2000

The State as a Chosen Woman: Brideservice and the Feeding of Tributaries in the Inka Empire. American Anthropologist 102(1): 84-97. 
Gose, Peter

2006

"Mountains historicized: ancestors and landscape in the Colonial Andes." In Penny

Dransart (ed.), Kay Pacha: Cultivating earth and water in the Andes, pp. 29-38. Oxford:

Archaeopress.

Gose, Peter

In press.

Invaders as Ancestors: On the Intercultural Making and Unmaking of Spanish Colonialism in the Andes.

Grondin, Jean

2002

"Gadamer's Basic Understanding of Understanding." In Robert Dostal (ed.), The

Cambridge Companion to Gadamer, pp. 36-51. Cambridge: Cambridge University Press.

Guaman Poma de Ayala, Felipe

1980 (1613)

Nueva Corónica y Buen Gobierno (vol. 1, trans. Franklin Pease). Caracas: Biblioteca Ayacucho.

Gutarra Carhuamaca, Jesús \& Mariano Valderrama León

2001

Pachamanca: El festín terrenal. Lima: Universidad San Martín de Porres.

Harris, Olivia

1989

"The earth and the state: the sources and meanings of money in Northern Potosí,

Bolivia." In Jonathan Parry \& Maurice Bloch (eds.), Money and the Morality of

Exchange, pp. 232-268. Cambridge: Cambridge University Press.

Harvey, David

1990

The Condition of Postmodernity: An Enquiry into the Origins of Cultural Change.

Cambridge: Blackwell.

Hobsbawm, E. J.

1974

Peasant Land Occupations. Past and Present 62: 120-152.

Instituto Nacional de Estadística e Informática (INEI)

Banco de Información Distrital. http://desea.inei.gob.pe. Accessed July 3, 2008.

Instituto Nacional de Estadisticas e Informática (INEI)

2008

Perú: Crecimiento y distribución de la población, 2007. Lima: INEI. 
Isbell, Billie Jean

1978

To Defend Ourselves: Ecology and Ritual in an Andean Village. Austin: University of Texas Press.

Kato, Takahiro

2005

"El pishtaco como intermediario entre la comunidad y la ciudad en el mundo andino." In Hiroyasu Tomoeda \& Luis Millones (eds.), Pasiones y desencuentros en la cultura andina, pp. 99-126. Lima: Fondo Editorial del Congreso de la República.

Klarén, Peter Flindell

2000

Peru: Society and Nationhood in the Andes. New York and Oxford: Oxford University Press.

Larson, Brooke \& Olivia Harris (eds.) (with Enrique Tandeter) 1995

Ethnicity, Markets, and Migration in the Andes. Durham: Duke University Press.

Lazar, Sian

2008

El Alto, Rebel City: Self and Citizenship in Andean Bolivia. Durham and New York:

Duke University Press.

Manrique, Nelson

1998

"The War for the Central Sierra." In Steve Stern (ed.), Shining and Other Paths: War and Society in Peru, 1980-1995, pp. 193-223. Durham and London: Duke University Press.

Mendoza Bellido, Alfredo \& Nancy Campos Pérez

2004

“Comidas y sabores de siempre." In Ana María Fries (ed.), Sabores y Saberes: Comida campesina andina, pp. 19-36. Lima: Proyecto Andino de Technologías Campesinas (PRATEC).

Misak, Cheryl

2004

“Charles Sanders Peirce (1839-1914)." In Cheryl Misak (ed.), The Cambridge

Companion to Peirce, pp. 1-26. Cambridge: Cambridge University Press.

Mitchell, William P.

1991

Peasants on the Edge: Crop, Cult, and Crisis in the Andes. Austin: University of Texas

Press. 
Murra, John V.

1975

Formaciones económicas y políticas del mundo andino. Lima: Instituto de Estudios

Peruanos.

Nash, June

1979

We Eat the Mines and the Mines Eat Us: Dependency and Exploitation in Bolivian Tin

Mines. New York: Columbia University Press.

Oakes, Timothy

1997

Place and the Paradox of Modernity. Annals of the Association of American Geographers 87(3): 509-531.

Ødegaard, Cecilie

2008

Informal Trade, Contrabando and Prosperous Socialities in Arequipa, Peru. Ethnos

73(2): 241-266.

Olivas Weston, Rosario (ed.)

1993

Cultura, Identidad y Cocina en el Perú. Lima: Universidad San Martín de Porres.

Olivas Weston, Rosario

1998

La Cocina en el Virreinato del Perú ( $2^{\text {nd }}$ ed.). Lima: Universidad San Martín de Porres.

Olivas Weston, Rosario

2001

La Cocina de los Incas: Costumbres gastronómicas y técnicas culinarias. Lima: Universidad San Martín de Porres.

Orta, Andrew

2004

Catechizing Culture: Missionaries, Aymara, and the "New Evangelization." New York: Columbia University Press.

Ossio, Juan

1993

"Aspectos simbólicos de las comidas andinas: una nueva versión." In Rosario Olivas Weston (ed.), Cultura, Identidad y Cocina en el Perú, pp. 77-113. Lima: Universidad San Martín de Porres. 
Paerregaard, Kartsen

1997

Linking Separate Worlds: Urban Migrants and Rural Lives in Peru. Oxford: Berg.

Radcliffe, Sarah

1990

Marking the Boundaries between Community, the State and History in the Andes.

Journal of Latin American Studies 22(3):575-594.

Rasnake, Roger

1986

Carnaval in Yura: Ritual Reflections on "ayllu" and State Relations. American

Ethnologist 13(4):662-680.

Robertson Smith, William

1927 (1889)

Lectures on the Religion of the Semites: The Fundamental Institutions ( $3^{\text {rd }}$ ed.). New

York: MacMillan.

Salazar-Soler, Carmen

2006

Supay Muqui, dios del socavón: Vida y mentalidades mineras. Lima: Fondo Editorial del Congreso del Perú.

Sallnow, Michael

1987

Pilgrims of the Andes: Regional Cults in Cusco. Washington: Smithsonian Institute Press.

Salman, Ton \& Annelies Zoomers (eds.)

2003

Imaging the Andes: Shifting Margins of a Marginal World. Amsterdam: Aksant Academic Publishers.

Seligmann, Linda

2004

Peruvian Street Lives: Culture, Power, and Economy among Market Women of Cuzco. Urbana and Chicago: University of Illinois Press.

Shusterman, Richard

1991

"Beneath Interpretation." In David Hiley, James Bohman, \& Richard Shusterman (eds.), The Interpretive Turn: Philosophy, Science, Culture, pp. 102-128. Ithaca: Cornell University Press. 
Sikkink, Lynn

1997

Water and Exchange: The Ritual of "yaku cambio" as Communal and Competitive

Encounter. American Ethnologist 24(1):170-189.

Skar, Sarah Lund

1994

Lives Together - Worlds Apart: Quechua Colonization in Jungle and City. Oslo:

Scandinavian University Press.

Slaney, Frances

2007

"Sacrifice as Cosmopolitan Savoir-Faire: Tarahumara (Rarámuri) articulations of the indigenous/cosmopolitan divide." Conference paper presented at the Canadian

Anthropology Society (CASCA) Annual Conference, Toronto, Canada, May 2007.

Spalding, Karen

1984

Huarochirí: An Andean Society Under Inca and Spanish Rule. Stanford: Stanford University Press.

Spedding, Alison $\mathrm{P}$.

2005

Sueños, kharisiris y curanderos: Dinámicas sociales de las creencias en los Andes contemporáneos. La Paz: Editorial Mama Huaco.

Sutton, David

2001

Remembrance of Repasts: An Anthropology of Food and Memory. Oxford and New York: Berg.

Sutton, David

2005

"Synesthesia, Memory, and the Taste of Home." In Carolyn Korsmeyer (ed.), The Taste Culture Reader: Experiencing Food and Drink, pp. 304-316. Oxford and New York:

Berg.

Tomoeda, Hiroyasu

2006

"Sirenas andinas." In Hiroyasu Tomoeda \& Luis Millones (eds.), Pasiones y desencuentros en la cultura andina, pp. 155-162. Lima: Fondo Editorial del Congreso de la República. 
Trawick, Paul

2003

The Struggle for Water in Peru: Comedy and Tragedy in the Andean Commons. Stanford:

Stanford University Press.

Wachterhauser, Brice

2002

"Getting it Right: Relativism, Realism, and Truth." In Robert Dostal (ed.), The

Cambridge Companion to Gadamer, pp. 52-78. Cambridge: Cambridge University Press.

Weismantel, Mary

1988

Food, Gender, and Poverty in the Ecuadorian Andes. Philadelphia: University of

Pennsylvania Press.

Weismantel, Mary

1989

"The Children Cry for Bread: Hegemony and the Transformation of Consumption." In Henry Rutz \& Benjamin Orlove (eds.), The Social Economy of Consumption, pp. 85-99. Lanham, MD: University Press of America.

Weismantel, Mary

1991

Maize Beer and Andean Social Transformations: Drunken Indians, Bread Babies, and Chosen Women. MLN 106(4): 861-879.

Weismantel, Mary

1999

"Tasty Meals and Bitter Gifts: Consumption and Production in the Ecuadorian Andes." In Carola Lentz (ed.), Changing Food Habits: Case Studies from Africa, South America and Europe, pp. 135-153. Amsterdam: Harwood Academic Publishers.

Zevallos Escobar, Balvino, Faustino Zevallos Escobar, \& Raul Huincho Castro 2004

"Llapanchikpa mikunanchik: La comida es de todos." In Ana María Fries (ed.), Sabores y Saberes: Comida campesina andina, pp. 37-52. Lima: Proyecto Andino de Technologías Campesinas (PRATEC).

Zoomers, Annelies \& Ton Salman

2003

"Straying Andean Ways: Reflecting on Andean-ness in a Globalizing World." In Ton Salman \& Annelies Zoomers (eds.), Imaging the Andes: Shifting Margins of a Marginal World, pp. 3-14. Amsterdam: Aksant Academic Publishers. 